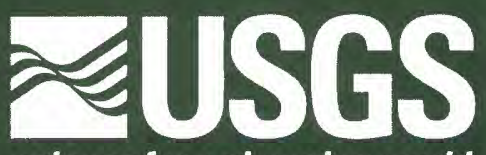

Prepared in cooperation with the City of Rapid City and the South Dakota Department of Game, Fish and Parks

\title{
Ground-Water and Surface-Water Interactions along Rapid Creek near Rapid City, South Dakota
}

Water-Resources Investigations Report 98-4214 
Cover photograph: Shows Cleghorn Springs Fish Hatchery and Canyon Lake.

Photograph by M.T. Anderson 


\section{Ground-Water and Surface-Water Interactions along Rapid Creek near Rapid City, South Dakota}

By Mark T. Anderson, Daniel G. Driscoll, and Joyce E. Williamson

Water-Resources Investigations Report 98-4214 


\section{U.S. Department of the Interior}

Bruce Babbitt, Secretary

\section{U.S. Geological Survey}

Charles G. Groat, Director

The use of firm, trade, and brand names in this report is for identification purposes only and does not constitute endorsement by the U.S. Geological Survey.

Rapid City, South Dakota: 1999

For additional information write to:

District Chief

U.S. Geological Survey

1608 Mt. View Road

Rapid City, SD 57702

Copies of this report can be purchased from:

U.S. Geological Survey

Branch of Information Services

Box 25286

Denver, CO 80225-0286 


\section{CONTENTS}

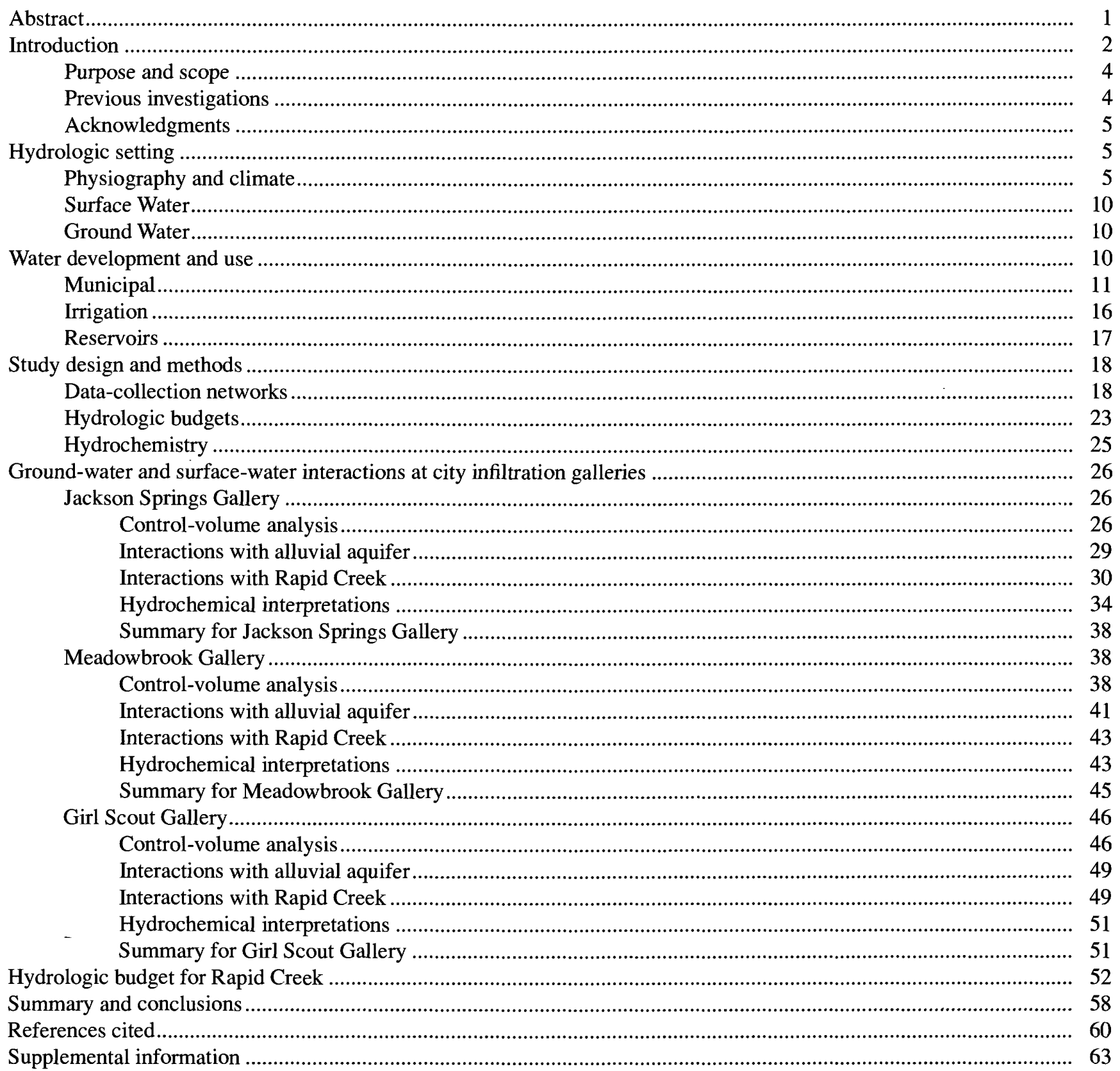

\section{ILLUSTRATIONS}

1. Map showing Rapid Creek Basin

2. Map showing location of study area, Rapid City water-supply facilities in use during 1990 , and streamflow-gaging stations used for study

3. Map showing generalized areal geology of study area. 


\section{ILLUSTRATIONS-Continued}

4. Diagram showing simplified diagramatic section of hydrogeologic setting of the Rapid City area

5. Graph showing chronology of development and operation of municipal water sources for Rapid City through 1990

6. Chart showing sources of finished municipal water for Rapid City during water years 1988-89........................... 14

7. Schematic cross section showing typical construction of infiltration galleries along Rapid Creek ......................... 15

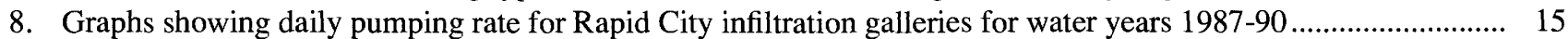

9. Graph showing municipal production of finished water (all sources) for Rapid City from 1943-90 ...................... 16

10. Graphs showing monthend usable contents of Deerfield and Pactola Reservoirs through 1990 ........................... 17

11. Schematic showing scheduled gallery cycling during October through December 1987-89 _.............................. 18

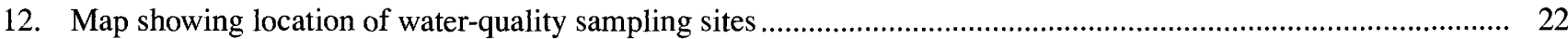

13. Map showing approximate extent of alluvial aquifer and cross-sectional boundaries to control-volume reaches

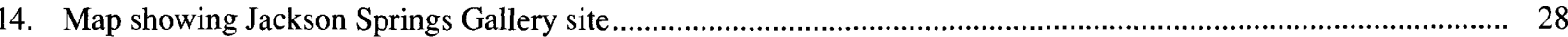

15. Graphs showing geologic sections from interpretation of Jackson-Cleghorn seismic-refraction profiles................. 29

16. Schematic of control volume for Jackson-Cleghorn Complex showing mean annual inflows and outflows during water years 1988-89

17. Graph showing measured water level of selected observation wells near Jackson Springs Gallery during gallery cycling, October 22 through November 13, 1987.

18. Cross-sectional profile of alluvial water level during gallery cycling at Jackson Springs Gallery ......

19. Graphs showing comparison of Jackson Springs Gallery pumping rate, gaged gain across reach, and outfall from Cleghorn Springs, October through December, water years 1988-90...

20. Graphs showing comparison of Rapid Creek streamflow, Jackson Springs Gallery pumping rate, and outfall from Cleghorn Springs, water years 1988-90

21. Percentile plot showing percent saturation of dissolved oxygen and nitrogen for Jackson-Cleghorn Complex and other selected sites

22. Graph showing relation between radium-228 and radium-226 isotopes for selected sites, with probable mixing line for Jackson and Cleghorn Springs

23. Graph showing relation between $\delta \mathrm{D}$ and $\delta^{18} \mathrm{O}$ illustrating the evolution of Rapid Creek water, with comparison to global meteoric water line

24. Graph showing relation between $\delta \mathrm{D}$ and $\delta^{18} \mathrm{O}$ for Rapid Creek and selected springs and Madison wells in study area

25. Map showing Meadowbrook Gallery site

26. Graph showing geologic section from interpretation of Meadowbrook seismic-refraction profile

27. Schematic of control volume for Meadowbrook Gallery showing mean annual inflows and outflows during water years 1988-89

28. Graph showing profile of Rapid Creek water-surface elevation near Meadowbrook Gallery, July 31 to August 1, 1989

29. Graph showing longitudinal profile of alluvial water level during gallery cycling at Meadowbrook Gallery.

30. Graph showing cross-sectional profiles of alluvial water level during gallery cycling at Meadowbrook Gallery.....

31. Graph showing measured water level of selected observation wells near Meadowbrook Gallery during gallery cycling, October 14 through November 7, 1988

32. Graphs showing comparison of Meadowbrook Gallery pumping rate, gaged gain (or loss) across reach, and gaged gain (or loss) across Leedy Ditch, October through December, water years 1988-90

33. Percentile plot showing percent saturation of dissolved oxygen and nitrogen for Meadowbrook Gallery and selected sites

34. Graph showing relation between $\delta \mathrm{D}$ and $\delta^{18} \mathrm{O}$ for Meadowbrook Gallery ...

35. Map showing Girl Scout Gallery site

36. Graphs showing geologic section from interpretation of Girl Scout seismic-refraction profiles...

37. Schematic of control volume for Girl Scout Gallery showing mean annual inflows and outflows during water years 1988-89 


\section{ILLUSTRATIONS-Continued}

38. Graph showing cross-sectional profile of alluvial water level during gallery cycling at Girl Scout Gallery

39. Graph showing measured water level of selected observation wells near Girl Scout Gallery during gallery cycling, October 14 through November 7, 1988

40. Graphs showing comparison of Girl Scout Gallery pumping rate, gaged gain (or loss) across reach, and gaged gain (or loss) across Storybook Ditch, October through December water years 1989-90.

41. Percentile plot showing percent saturation of dissolved oxygen and nitrogen for Girl Scout Gallery and selected sites.

42. Graph showing relation between $\delta \mathrm{D}$ and $\delta^{18} \mathrm{O}$ for Girl Scout Gallery

43. Schematic showing hydrologic budget for Rapid Creek between gaging stations 06411500 (below Pactola Dam) and 06414000 (at Rapid City), water years 1988-89

44. Graph showing comparison of water-surface elevation of Madison aquifer in Brooks Cave and flow of Rapid Creek, water years 1989-90

45. Photograph of staff gage in Brooks Cave.....

46. Graph showing comparison of alluvial water-surface elevations in alluvial wells and

Rapid Creek, July 10 through July 20, 1989.

\section{TABLES}

1. Generalized stratigraphic sequence and aquifers in study area ...................................................................

2. Selected information on Rapid City production wells............................................................................ 13

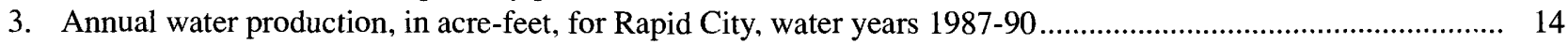

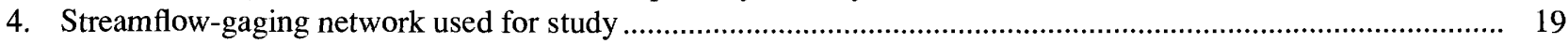

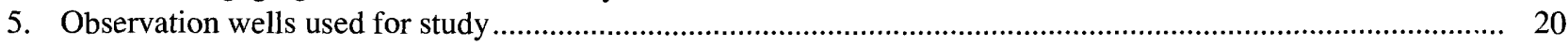

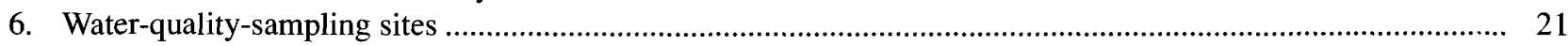

7. Annual flow, in acre-feet per year, for stations in streamflow-gaging network ............................................ 24

8. Comparison of mean daily flow values for selected pumping and nonpumping periods at the Jackson-Cleghorn Complex.....

9. Monthly differences in flow of Rapid Creek ${ }^{1}$, water years 1987-90 …...........................................................

10. Results of regression analyses for monthly difference in flow of Rapid Creek across study reach as a function of Rapid City municipal water production....

11. Chronology of historical events relevant to water development in the Rapid Creek Basin..

12. Summary of monthly water production, in millions of gallons, Rapid City, South Dakota, water years 1987-90.

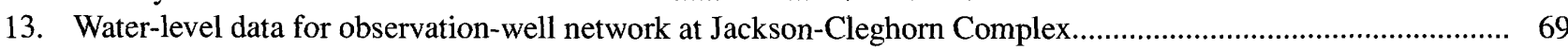

14. Water-level data for observation-well network at Meadowbrook Gallery .................................................... 72

15. Water-level data for observation-well network at Girl Scout Gallery ............................................................. 77

16. Water-level data for observation-well network near Water Treatment Plant ..................................................... 80

17. Daily mean streamflow data, pumping data, and calculated values, in cubic feet per second, during periods of gallery cycling at Jackson-Cleghorn Complex

18. Field measurements and calculated values of dissolved nitrogen and oxygen for selected sites in study area...... 86

19. Isotope data for oxygen, hydrogen, and radium for selected sites in study area ................................................ 95 


\begin{tabular}{|c|c|c|}
\hline Multiply & By & To obtain \\
\hline \multicolumn{3}{|c|}{ Length } \\
\hline inch (in). & 2.54 & centimeter \\
\hline inch (in.) & 25.4 & millimeter \\
\hline foot $(f t)$ & 0.3048 & meter \\
\hline mile (mi) & 1.609 & kilometer \\
\hline \multicolumn{3}{|c|}{ Area } \\
\hline acre & 4,047 & square meter \\
\hline acre & 0.4047 & hectare \\
\hline square foot $\left(\mathrm{ft}^{2}\right)$ & 0.09290 & square meter \\
\hline square mile $\left(\mathrm{mi}^{2}\right)$ & 2.590 & square kilometer \\
\hline \multicolumn{3}{|c|}{ Volume } \\
\hline million gallons (Mgal) & 3,785 & cubic meter \\
\hline acre-foot (acre-ft) & 1,233 & cubic meter \\
\hline acre-foot (acre-ft) & 0.001233 & cubic hectometer \\
\hline \multicolumn{3}{|c|}{ Flow rate } \\
\hline gallon per minute (gal/min) & 0.06309 & liter per second \\
\hline cubic foot per second $\left(\mathrm{ft}^{3} / \mathrm{s}\right)$ & 0.02832 & cubic meter per second \\
\hline million gallons per day (Mgal/d) & 0.04381 & cubic meter per second \\
\hline million gallons per day (Mgal/d) & 1.54723 & cubic foot per second per day \\
\hline acre-foot per year (acre-ft/yr) & 1,233 & cubic meter per year \\
\hline
\end{tabular}

Temperature in degrees Celsius $\left({ }^{\circ} \mathrm{C}\right)$ may be converted to degrees Fahrenheit $\left({ }^{\circ} \mathrm{F}\right)$ as follows:

${ }^{\circ} \mathrm{F}=1.8^{\circ} \mathrm{C}+32$

Temperature in degrees Fahrenheit $\left({ }^{\circ} \mathrm{F}\right)$ may be converted to degrees Celsius $\left({ }^{\circ} \mathrm{C}\right)$ as follows:

${ }^{\circ} \mathrm{C}=\left({ }^{\circ} \mathrm{F}-32\right) / 1.8$

Sea level: In this report, "sea level" refers to the National Geodetic Vertical Datum of 1929 (NGVD of 1929)--a geodetic datum derived from a general adjustment of the first-order level nets of both the United States and Canada, formerly called Sea Level Datum of 1929.

Water year: In Geological Survey reports dealing with surface-water supply, water year is the 12-month period, October 1 through September 30. The water year is designated by the calendar year in which it ends; thus, the water year ending September 30,1991, is called the "1991 water year." 


\title{
Ground-Water and Surface-Water Interactions along Rapid Creek near Rapid City, South Dakota
}

\author{
By Mark T. Anderson, Daniel G. Driscoll, and Joyce E. Williamson
}

\section{ABSTRACT}

Complex interactions between Rapid Creek and ground water occur between Pactola Reservoir and central Rapid City. Streamflow losses west of Rapid City recharge aquifers in the Madison Limestone and Minnelusa Formation, and artesian springflow from these aquifers occurs in several locations in Rapid City. Natural interactions are complicated by withdrawals from three municipal infiltration galleries located in shallow alluvial deposits adjacent to Rapid Creek. Rapid City also obtains water from deep wells completed in the Madison and Minnelusa aquifers. Peak demand is supplemented by the municipal Water Treatment Plant, using direct withdrawals from Rapid Creek.

Interactions between ground water and surface water near the three infiltration galleries were studied extensively. Control-volume analyses were used to quantify bedrock springflow at each site, and interactions between the galleries, the alluvial aquifer, and Rapid Creek were examined. Hydrochemical data also were used to identify probable sources of water to each gallery. Hydrologic budgets were developed for water years 1988-89 for five subreaches of Rapid Creek between Pactola Reservoir and central Rapid City. These were two of the driest years on record for the Rapid City area.

Springflow from Jackson and Cleghorn Springs averaged $21.6 \mathrm{ft}^{3} / \mathrm{s}$ during water years 1988-89. These springs are the primary source for the Jackson Springs Gallery, which produced an average of $6.0 \mathrm{ft}^{3} / \mathrm{s}$. Flow of the outfall from the adjacent Cleghorn Springs Fish Hatchery averaged $11.5 \mathrm{ft}^{3} / \mathrm{s}$, and the remainder of the bedrock springflow is contributed to Rapid Creek by seepage through the adjacent alluvium. Gallery pumping causes drawdown of about $5 \mathrm{ft}$ below the adjacent creek level; however, drawdown in nearby alluvial observations wells is only abc'it $2 \mathrm{ft}$, with the hydraulic gradient remaining toward Rapid Creek. Water levels in the alluvial aquifer recover within 2 days after pumping is discortinued, and flows respond almost immediately in Rapid Creek and the hatchery outfall.

Water from Jackson and Cleghorn Springs is supersaturated with dissolved nitrogen gas and undersaturated with dissolved oxygen, which is characteristic of bedrock aquifers in the area, but different than Rapid Creek. Gas saturation values in the gallery water indicate a minor component of creek water, as do values for radium isotopes. Interpretations of data for stable isotopes of $\mathrm{cxy}$ gen and hydrogen indicate that about 90 percent of the gallery production is bedrock springflow and about 10 percent is induced infiltration from Rapid Creek. Jackson and Cleghorn Springs are concluded to be a regional discharge point for the Madison aquifer. Springflow consists of isotopically heavier water from the Madison aquifer south of Rapid Creek and a slightly smaller component of isotopically lighter water, which cor sists of a mix (of unknown proportions) of water f "om the north and water recharged in the loss zone of Rapid Creek. 
During water years 1988-89, the Meadowbrook and Girl Scout Galleries produced about 2.9 and $1.2 \mathrm{ft}^{3} / \mathrm{s}$, respectively, of which about onethird to one-half was calculated to originate from bedrock springflow. Error analyses indicate that the uncertainties associated with these estimates are large. Pumping induced a hydraulic gradient within the alluvial aquifer from Rapid Creek to both galleries. Complete recovery of water levels in the alluvial aquifer required about 2 weeks and 1 week, respectively, for the Meadowbrook and Girl Scout Galleries. Effects on Rapid Creek were difficult to quantify because of relatively small pumping rates, large alluvial influences, and large streamflow variability that results from upstream influences. No evidence was found that gallery pumping affects the flow of Leedy Ditch; however, flow in Storybook Ditch is affected. Hydrochemical data confirm the presence of creek water resulting from induced infiltration at both galleries; however, probable components of bedrock springflow also are indicated. The combination of evidence indicates that induced infiltration occurs at both sites; however, bedrock springflow probably is an additional source for both Meadowbrook and Girl Scout Galleries.

Hydrologic budgets were used to quantify ground-water seepage for five subreaches of Rapid Creek for water years 1988-89. Between Pactola Reservoir and Rapid City (subreach 1), Rapid Creek loses about $8.4 \mathrm{ft}^{3} / \mathrm{s}$ as recharge to bedrock aquifers. Near Canyon Lake (subreach 3), seepage of about $2.3 \mathrm{ft}^{3} / \mathrm{s}$ may occur from Rapid Creek to alluvial deposits or to outcrops of various bedrock units; however, the uncertainty of the estimate is large. Interactions with ground water were negligible in subreach 5 , which includes the municipal Water Treatment Plant. Results for two subreaches containing galleries were consistent with results of control-volume analyses.

For the entire reach from Pactola Reservoir to central Rapid City, net seepage from Rapid Creek to ground water was $8.2 \mathrm{ft}^{3} / \mathrm{s}$; however, the average flow of Rapid Creek increased by about $1.3 \mathrm{ft}^{3} / \mathrm{s}$, because surface inflows exceeded the sum of net seepage and surface withdrawals. On a monthly basis during water years 1987-90, the change in flow through the entire reach ranged from a decrease of about $21 \mathrm{ft}^{3} / \mathrm{s}$, during months of peak demand, to an increase of about $21 \mathrm{ft}^{3} / \mathrm{s}$. Linear regression was used to identify relations between monthly difference in streamflow and municipal production. Assuming no w:thdrawals and minimal tributary inflows, a net inc "ease of about $17 \mathrm{ft}^{3} / \mathrm{s}$ generally would result from interactions with bedrock aquifers that occur within the reach (springflow less streamflow losses).

\section{INTRODUCTION}

Rapid Creek provides water for recreation, irrigation, and a substantial part of the municipal water supply for the City of Rapid City, South D rkota. As Rapid Creek flows from the higher altitudes of the Black Hills to its confluence with the Cheyenne River near Creston (fig. 1), the water is used and reused for these purposes, some of which are in direct. competition. Because the flow of Rapid Creek is fully appropriated, no new water rights can be issued (John Hatch, South Dakota Department of Environment and Natural Resources, Water Rights Division, written commun., 1991).

As the population of Rapid City has increased, so has the demand for municipal water. Prior to 1990, the City secured its municipal water supply during periods of low to moderate demand from three infiltration galleries in the alluvial gravels near Rapid Creek and from several deep wells completed primarily in the Minnelusa aquifer. Peak demand was met by direct withdrawals from Rapid Creek that are purified by the Water Treatment Plant. During 1989-91, the City developed additional supply by completing seven deep wells in the Madison aquifer.

In 1952, the City entered into a long-term contract with the Bureau of Reclamation (1952.a) for water to be stored and delivered from Pactola Reservoir. Under the terms of this contract, the assumption is made that pumping the City's infiltration galleries, which are constructed in the alluvial flood plain along Rapid Creek, is equivalent to pumping directly from the creek. During the irrigation season, the City is required to purchase an equal volume of water from Pactola Reservoir to replace the water with trawn from the three infiltration galleries. 

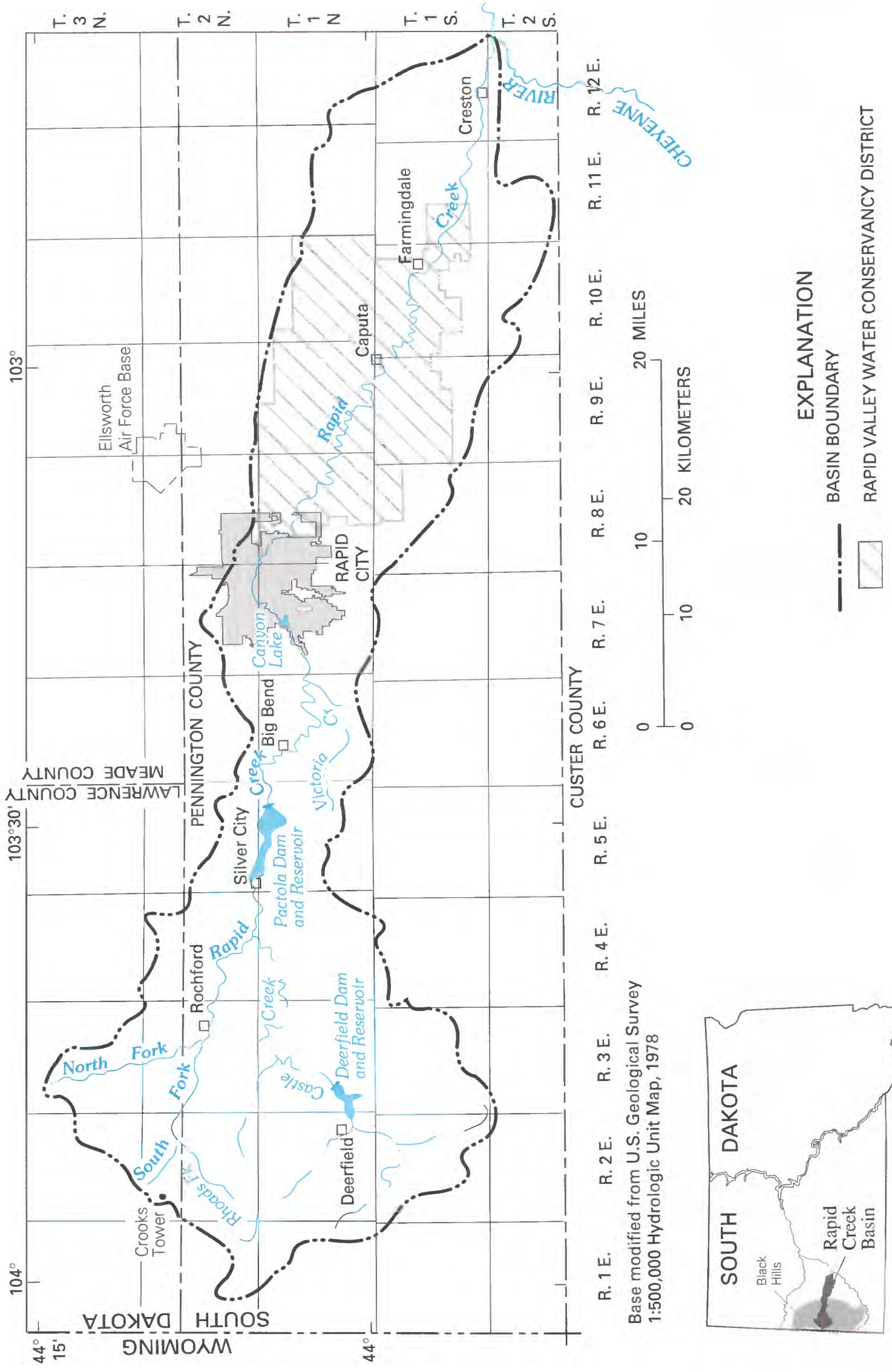

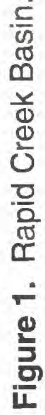


Water from Pactola Reservoir is delivered to Rapid City within the natural channel of Rapid Creek, which traverses outcrops of several bedrock formations. Most notable are the Madison Limestone and Minnelusa Formation, which contain regionally extensive, carbonate aquifers. Complex ground-water and surface-water interactions result from large secondary permeability within these aquifers. Large streamflow losses from Rapid Creek recharge these aquifers west of Rapid City and artesian springflow occurs in various locations. Natural interactions are complicated by municipal and irrigation withdrawals from Rapid Creek and its extensive alluvial aquifer. A hydrologic budget for Rapid Creek was needed to aid in the management of this complicated system.

The South Dakota Department of Game, Fish and Parks operates the Cleghorn Springs Fish Hatchery using springflow from Cleghorn Springs. Supersaturation of nitrogen gas limited fish production because of the so-called Gas Bubble Disease (Larry Ferber, Hatchery Manager, oral commun., 1987). Cleghorn Springs is located immediately adjacent to Jackson Springs, and, collectively, these springs comprise one of the largest carbonate spring systems in the Black Hills area. Jackson Springs is the site of an infiltration gallery that provides municipal water for Rapid City. Operation of the gallery was believed to affect the flow of water available to the hatchery (Larry Ferber, Hatchery Manager, oral commun., 1987). Large-scale development of water from bedrock aquifers could diminish the flow of these and other springs. Thus, quantification of ground-water and surface-water interactions along Rapid Creek was needed.

In response to these needs, the U.S. Geological Survey, in cooperation with the City of Rapid City and the South Dakota Department of Game, Fish and Parks, conducted a study of ground-water and surface-water interactions along Rapid Creek, with an emphasis on the infiltration galleries. The study area generally is that part of the Rapid Creek Basin extending from Pactola Reservoir downstream to central Rapid City (fig. 2). The study area generally extends from Boxelder Creek on the north to Spring Creek on the south but is not rigidly bounded because of the karst terrain and complex ground-water flowpaths.

\section{Purpose and Scope}

The purpose of the study was to quantify interactions between ground water and surface water along
Rapid Creek near Rapid City. This report (1) describes interactions between Rapid Creek and its alluvial aquifer at Rapid City's three infiltration galleries; (2) identifies potential sources of springflow from bedrock aquifers that may contribute flow to the infiltration galleries; and (3) describes a hydrologic budget for Rapid Creek from Pactola Reservoir to central Rapid City. Although the study was conducted during 1987-90, detailed hydrologic budgeting generally is restricted to water years (WY) 1988-89, when an extensive network of streamflow-gaging stations was operated along Rapid Creek.

\section{Previous Investigations}

The water resources of Rapid Creek were first described in a general way during the early investigations of Darton (1909) in the Black Hills. Streamflow gaging along Rapid Creek was initiated during WY 1903 at gaging station 06414000 (fig. 2); however, the station was discontinued during WY 1907. The first quantitative estimates of springflow from Cleghorn and Jackson Springs were made by Rahn and Gries (1973). A statistical summary of streamflow data for the Rapid Creek Basin was compiled by Driscoll and Zogorski (1990).

The Bureau of Reclamation (1985a) projected water demand and examined Rapid Creek as a source of water to meet increasing municipal demand for Rapid City. The report concluded that the City would not have sufficient water to meet demand should the area suffer 3 consecutive years of drought. The bedrock aquifers in the vicinity of Rapid City and their potential for development as municipal water-supply sources were described by Peter (1985). Greene (1992) used seismic refraction to determine the depth to water and saturated thickness of the alluvial aquifer at several places along Rapid Creek. Greene (1993) described hydraulic properties of the Madison aquifer in western Rapid City.

An investigation of the nutrient status of Canyon Lake was conducted by Stewart and others (1989). Various studies of water quality in Rapid Creek were reviewed and summarized by Zogorski and others (1990). Water-quality data for the Rapid Creek Basin were summarized by Freeman and Komor (1991), and data for trace metals in water, sediment, plants, and fish in Rapid Creek were presented by Williamson and others (1996). 
Many graduate students conducted research as part of this study to fulfill graduate degree requirements at the South Dakota School of Mines and Technology. Driscoll (1987) described streamflow and water-yield characteristics of Rapid Creek, and Packard (1988) developed a computer model on the hydrologic flow characteristics of Rapid Creek. Williams (1988) conducted research on nitrogen gas supersaturation in ground water. Soedjatmiko (1990) used seismic refraction to determine the total thickness and saturated thickness of the alluvial aquifer near the infiltration gallery sites. Hines (1991) studied streamflow losses and gains in Dark Canyon upstream of Rapid City. Other research efforts include Stetler's investigation (1989) of potential infiltration gallery sites, Jorgenson's (1990) investigation of water-quality characteristics, and Geibel's (1991) investigation of groundwater-flow conditions of the Rapid Creek alluvial aquifer. Davis (1991) summarized the efforts of Stetler, Soedjatmiko, and Geibel. Delzer (1993) conducted a survey of water quality and nutrients in Rapid Creek and Canyon Lake.

Streamflow losses and gains for selected reaches of Rapid Creek have been studied previously; however, this study presents a more thorough examination of ground- and surface-water interactions between Pactola Reservoir and central Rapid City. Extensive applications of hydrochemistry also are used to help resolve the various sources and flowpaths of water along Rapid Creek.

\section{Acknowledgments}

The authors acknowledge the advice, insight, and cooperation provided by William R. Craig, John Wagner, and Rodger A. Kruger of the Rapid City Public Works Department, Water Division. Personnel from the Water Division were very helpful in controlling pumping rates from various sources. Robert Bushong, Bureau of Reclamation damtender at Pactola Reservoir, was very helpful in adjusting reservoir releases.

Rick Baker of FMG, Inc., provided detailed information on observation wells that were completed in the alluvium. Ron Glover of the South Dakota Department of Game, Fish and Parks expedited the approval for permits needed to modify the stream channel for streamflow gaging.

Larry A. Ferber, manager of the Cleghorn Springs Fish Hatchery, provided construction equipment and staff assistance to build and maintain streamflow-gaging sites. Ray Kraemer, long-time resident and keeper of the Storybook Ditch, was especially cooperative in monitoring the ditch and keeping it clear of debris.

Esther Serr, local historian, researched the history of water development in Rapid City. Technical assistance was provided by the Civil Engineering and Geological Engineering Departments at the South Dakota School of Mines and Technology.

\section{HYDROLOGIC SETTING}

The Black Hills of South Dakota and Wyoming were formed by a large domal uplift during the Laramide orogeny (Late Cretaceous-Early Tertiary). Erosion of the overlying sedimentary rock units has exposed the Precambrian core in the central Black Hills (Rahn and Gries, 1973).

Rapid Creek is a major tributary to the Cheyenne River and drains a total area of slightly more than $710 \mathrm{mi}^{2}$. The headwaters of the Rapid Creek Basin (fig. 1) are predominantly within outcrops of the Madison Limestone, Englewood Formation, and Deadwood Formation of Paleozoic age (DeWitt and others, 1989). Numerous headwater springs that originate near the base of the Madison Limestone provide a steady source of base flow into Deerfield and Pactola Reservoirs, which are located within outcrops of Precambrian metamorphic rocks. The areal geology of the study area is shown in figure 3 , and a stratigraphic section showing the water-bearing characteristics of each unit is presented in table 1 .

\section{Physiography and Climate}

The climate of the Rapid Creek Basin is influenced by altitude, which ranges from about $2,400 \mathrm{ft}$ above sea level at the confluence with the Cheyenne River to $7,137 \mathrm{ft}$ above sea level at Crooks Tower.

Normal annual air temperatures decrease with increasing altitude and range from $46.6^{\circ} \mathrm{F}$ at Rapid City to about $40.0^{\circ} \mathrm{F}$ at Pactola Dam (U.S. Department of Commerce, 1990). Large daily and seasonal temperature variations, which are characteristic of semiarid continental climates, occur within the study area. Normal annual precipitation increases with altitude and ranges from an average of 17.04 in. at Rapid City to 19.58 in. at Pactola Dam (U.S. Department of Commerce, 1990). 


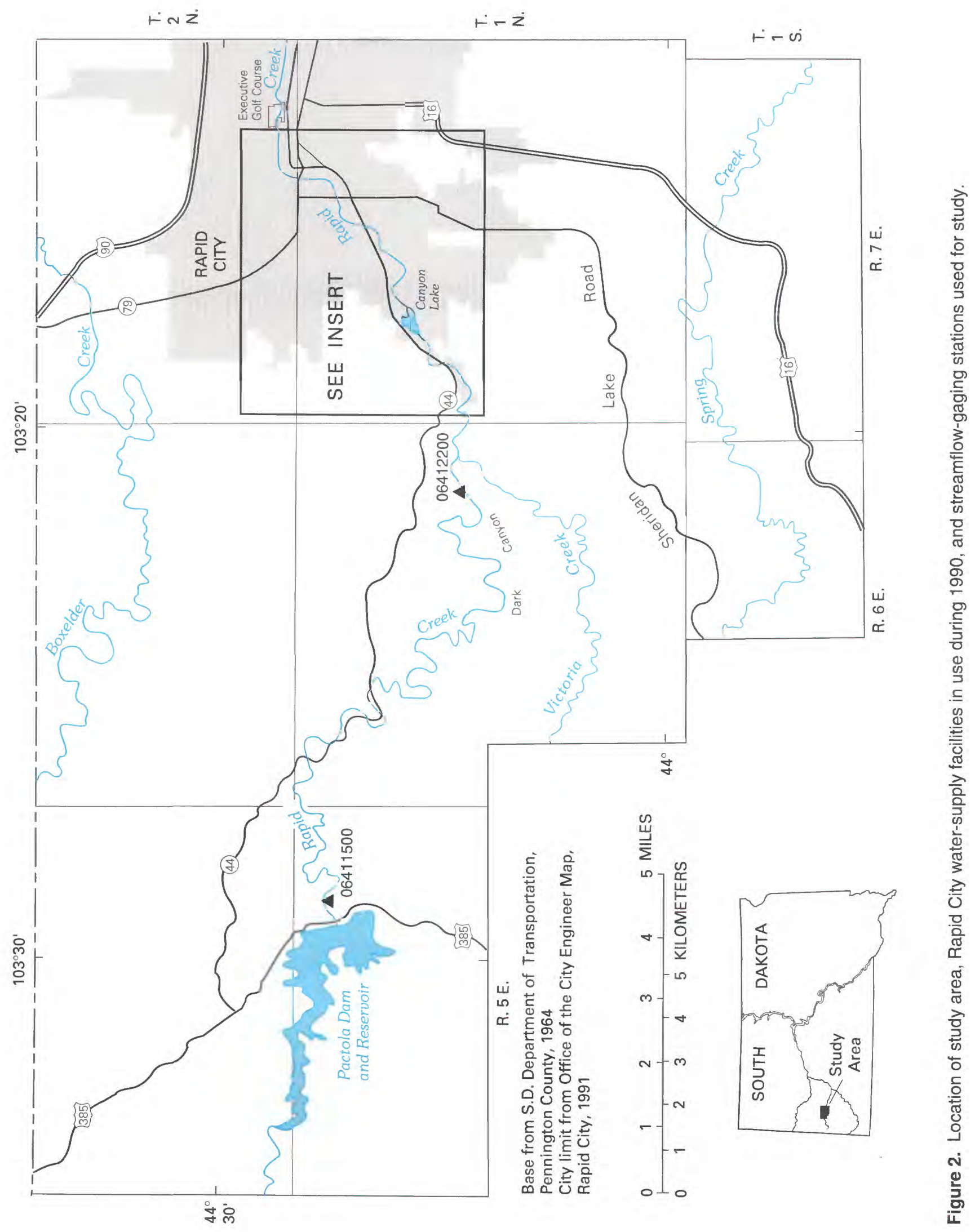




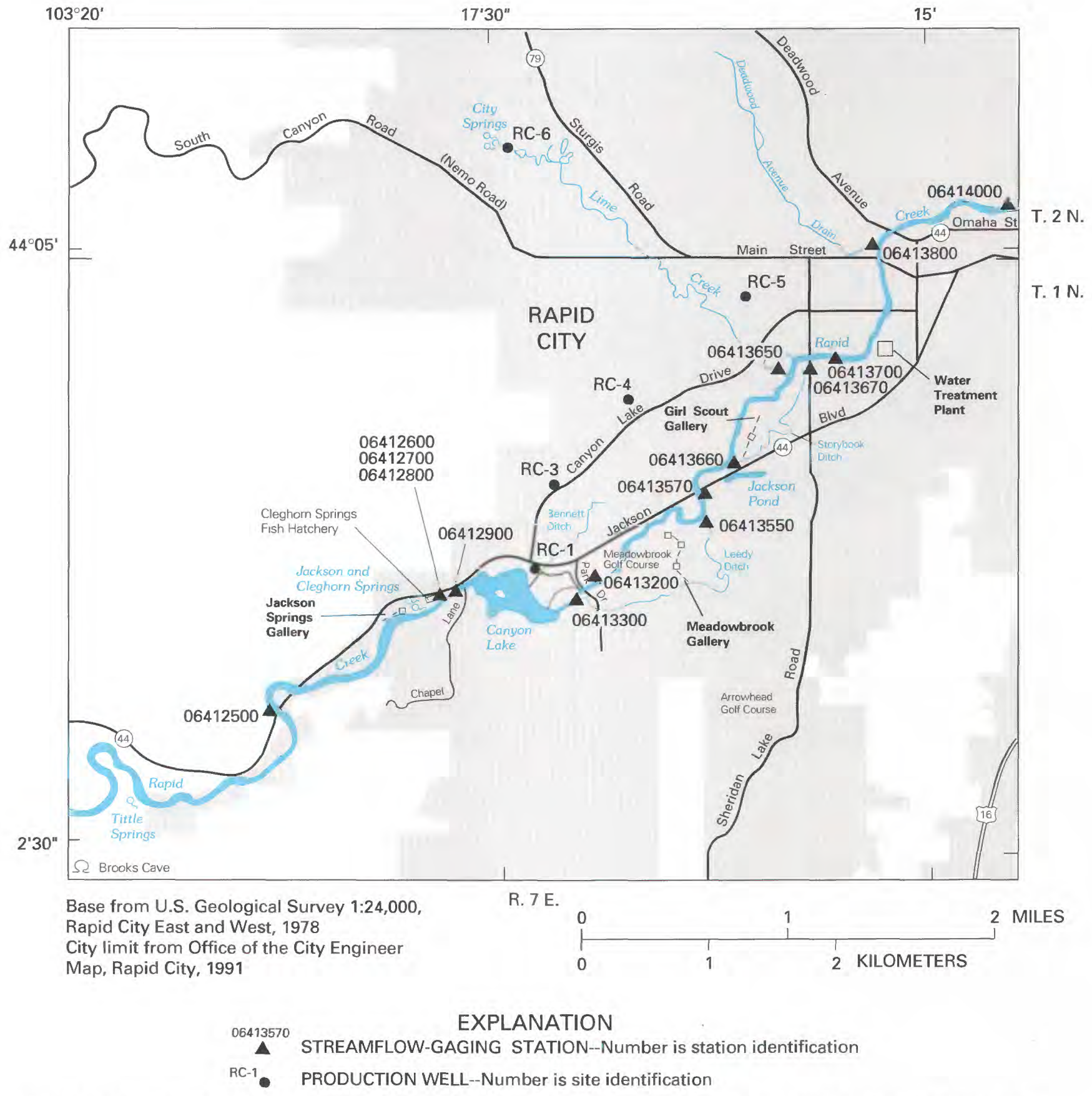

Figure 2. Location of study area showing Rapid City water-supply facilities in use during 1990 and streamflow-gaging stations used for study.--Continued 


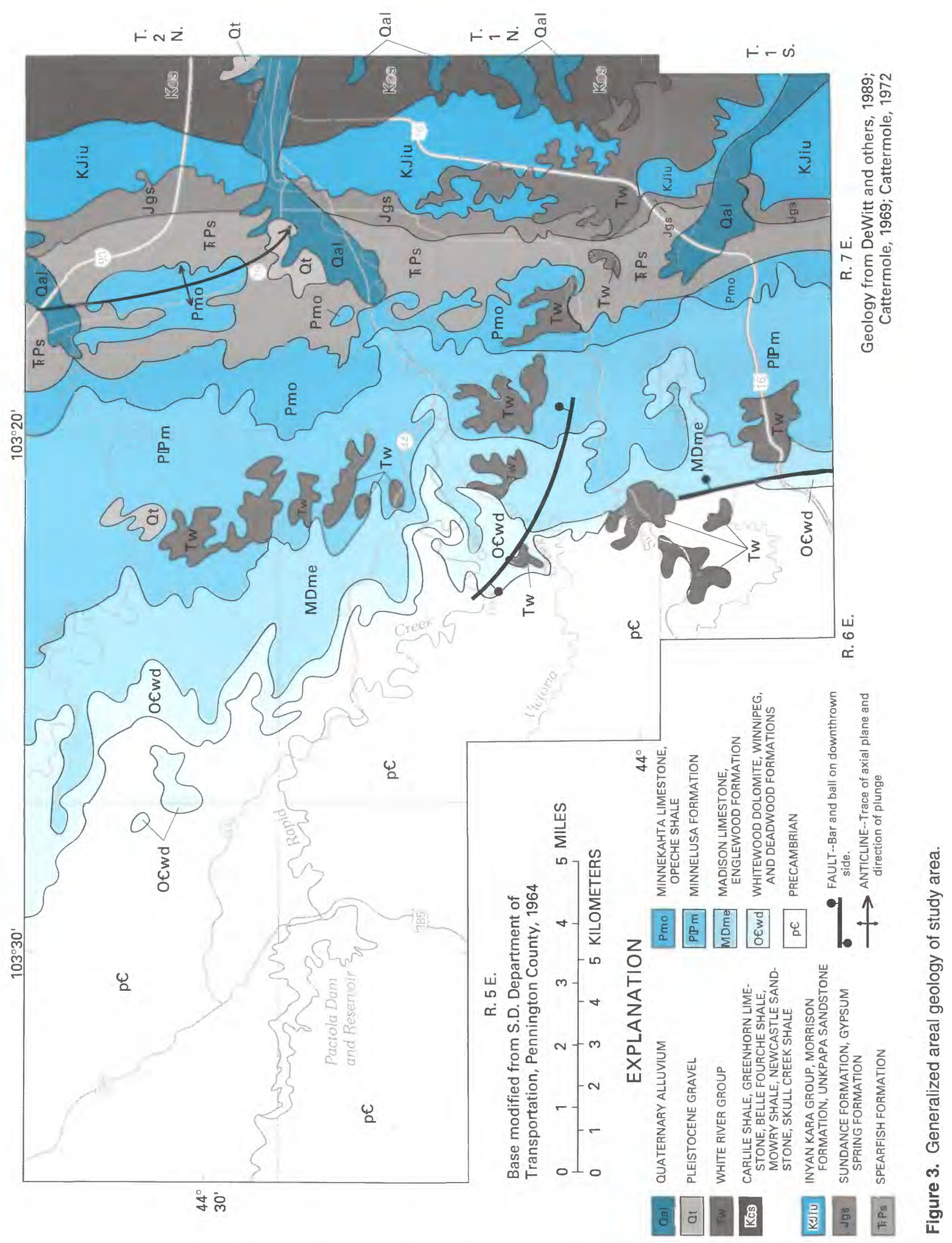


Table 1. Generalized stratigraphic sequence and aquifers in study area

[Modified from Robinson and others, 1964; Cattermole, 1969 and 1972; and Brown and others, 1982]

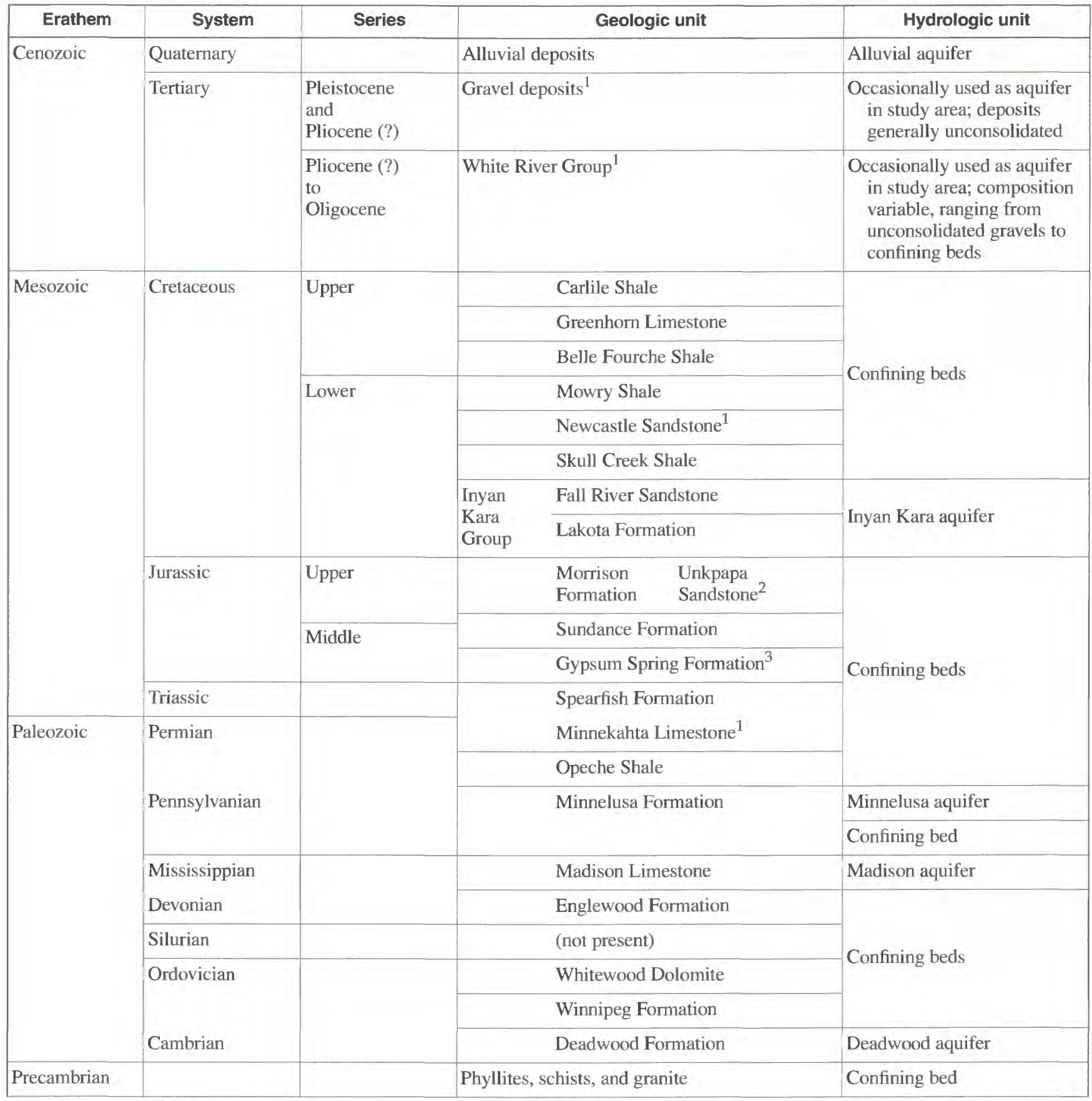

${ }^{1}$ Occasionally used as minor source of water supply in the study area.

${ }^{2}$ Occurs only in the southern and eastern Black Hills.

${ }^{3}$ Occurs only in the northern and western Black Hills. 
Convective thunderstorms caused by orographic effects frequently produce intense rainfall. Rapid Creek has a history of flash flooding because of the steep terrain and narrow canyons. The most notable flood of record occurred June 9-10, 1972, when Rapid Creek peaked at an estimated $50,000 \mathrm{ft}^{3} / \mathrm{s}$ in Rapid City and 237 people were killed (Schwarz and others, 1975).

Land use has become increasingly diverse as multiple uses of natural resources have developed. Ponderosa pine is the most important tree species in the higher altitudes (Orr, 1959), both in terms of the timber industry and in terms of water use (evapotranspiration). Numerous phreatophytes, including cottonwood and various species of elm, poplar, and willow, also have the potential to transpire large amounts of water in the lower altitudes, especially along creek bottoms (Packard, 1988).

\section{Surface Water}

The average annual streamflow of Rapid Creek through WY 1990 at gaging station 06414000 (fig. 2) is $59.3 \mathrm{ft}^{3} / \mathrm{s}$ (U.S. Geological Survey, 1991). The flow in Rapid Creek is regulated by Deerfield and Pactola Reservoirs. Maximum releases occur in summer in response to irrigation and municipal demand during the growing season. A minimum of about $15 \mathrm{ft}^{3} / \mathrm{s}$ generally is released from Pactola Reservoir during the winter.

Most Black Hills streams are diminished as they flow across outcrops of Paleozoic rocks (primarily the Madison Limestone and Minnelusa Formation) that are exposed around the periphery of the Black Hills (Rahn and Gries, 1973). Based on long-term streamflow records, net losses from Rapid Creek in Dark Canyon (fig. 3) west of Rapid City average about 4 to $6 \mathrm{ft}^{3} / \mathrm{s}$ (Peter, 1985; Driscoll, 1987). Boxelder Creek to the north of Rapid Creek and Spring Creek to the south generally lose all of their base flow in crossing these outcrops (Rahn and Gries, 1973).

\section{Ground Water}

The Madison Limestone and Minnelusa Formation contain important, regionally extensive aquifers that are recharged through infiltration of precipitation on outcrop areas and through streamflow losses. Where confined by the overlying Spearfish Formation and other units (Greene, 1993), the Madison and Minnelusa aquifers generally have artesian pressure and vertical ground-water leakage generally is upward.
The Madison and Minnelusa aquifers generally are unconfined west of Rapid City, where streamflow losses occur, but have artesian pressure at all of the City's infiltration galleries, as evidenced by water-level records for various observation wells (Driscoll and others, 1996). Ground-water flow is generally eastward for bedrock aquifers within the study area, including the Madison and Minnelusa aquifers (Peter, 1985; Greene, 1993). Alluvial ground-water flow also is generally eastward (Stetler, 1989).

Several artesian springs, believed to originate primarily from the Madison Limestone (Peter, 1985), rise up through the overlying Minnelusa Formation and discharge near the contact between the Minnekahta Limestone, which is a minor aquifer in the study area (table 1), and the Spearfish Formation. These springs include Jackson Springs, Cleghorn Springs, and City Springs (fig. 2) which, if not for pumping, would collectively discharge about $25 \mathrm{ft}^{3} / \mathrm{s}$ in west Rapid City (Driscoll, 1987). A simplified three-dimensional depiction of the hydrogeologic setting in the area of Rapid City is shown in figure 4.

The Rapid Creek alluvial aquifer (fig. 4) is formed by deposits of erosional remnants of bedrock units. These deposits are of limited extent upstream from Canyon Lake but generally increase in width and thickness downstream (fig. 3). The alluvial deposits typically consist of boulders, cobbles, gravel, sand, and clay. Particle sizes grade from notably coarser near Canyon Lake to much finer toward the eastern boundary of the study area (Stetler, 1989). The coarser deposits are permeable enough to yield large volumes of water to shallow wells despite a relatively thin saturated thickness.

Rapid Creek progresses through outcrops of Mesozoic shales, sandstones, and limestones (fig. 3) in the "Gap" area of Rapid City (fig. 4). Of the Mesozoic units, only the Inyan Kara Group has particular importance as a regional aquifer (table 1), and none of the units measurably affect the flow of Rapid Creek (Peter, 1985).

\section{WATER DEVELOPMENT AND USE}

The development and use of water by settlers in the Rapid Creek Basin began in the late 1870s, with the first water right granted in 1877 for agricultural purposes. The first municipal water right in the basin was secured by Rapid City in December 1885 , when the City purchased the land and "perpetual rights to the 


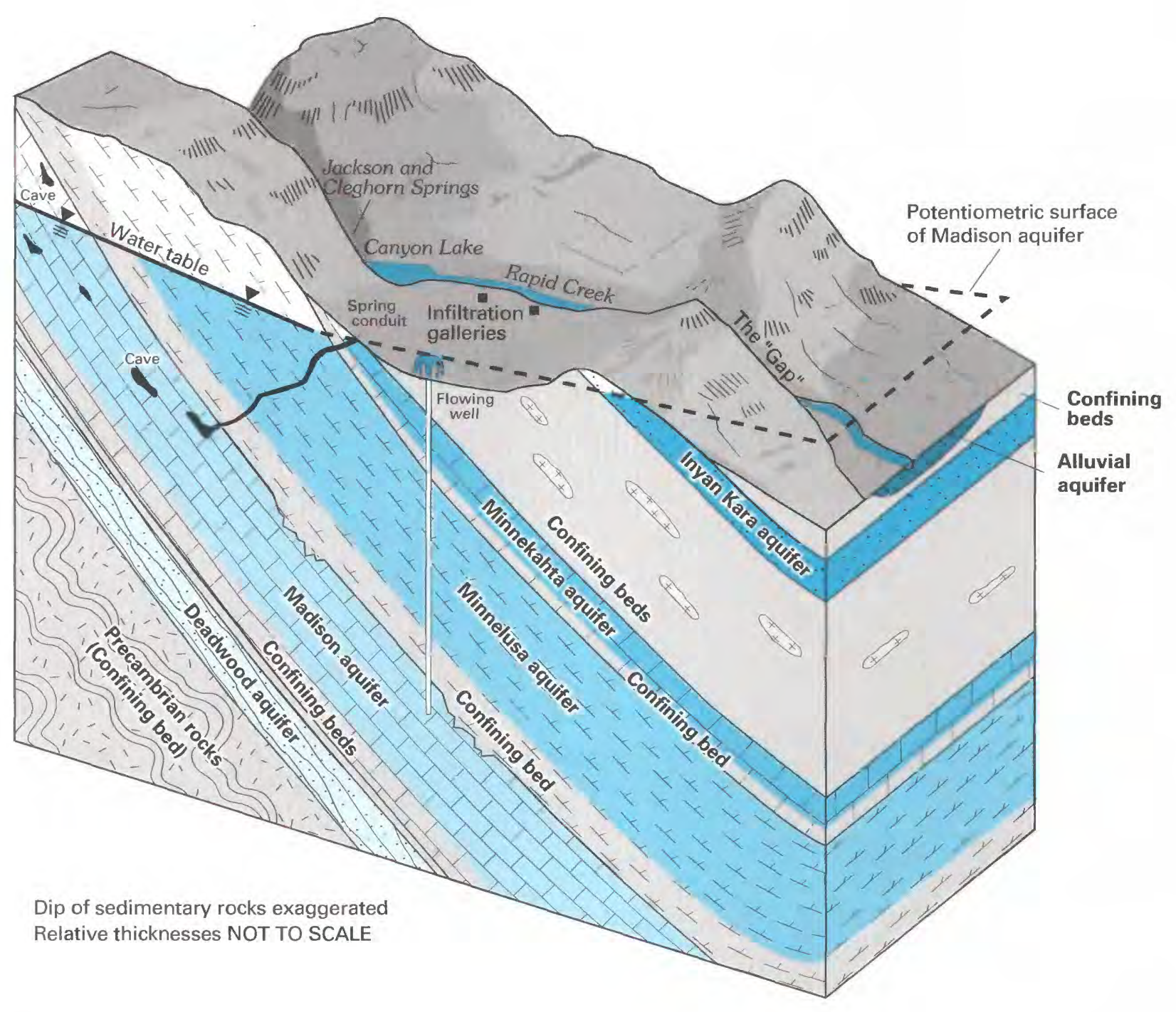

Figure 4. Simplified diagramatic section of hydrogeologic setting in Rapid City area.

use of" City Springs (Earl Grant, local historian, written commun., 1953). A chronology of events relevant to water development in the Rapid Creek Basin is presented in table 11 in the Supplemental Information section at the end of this report. A summary of municipal water development through 1990 is shown in figure 5 and locations of municipal water-supply facilities in use during 1990 are shown in figure 2.

\section{Municipal}

Rapid City's first distribution system (fig. 5) began delivery of water from City Springs (fig. 2) in
November 1886 (Earl Grant, local historian, written commun., 1953; Stetler, 1989). Cleghorn Springs was developed by the Federal government in 1906 for an Indian hospital built in west Rapid City. The pipeline to the hospital subsequently was used by residents along the line and eventually became the responsibility of the Cleghorn Springs Water Users Association.

Further development of City Springs and Tittle Springs in Dark Canyon provided adequate water for the City's growing population until drought conditions of the 1930's (Earl Grant, local historian, written commun., 1953; Stetler, 1989). 

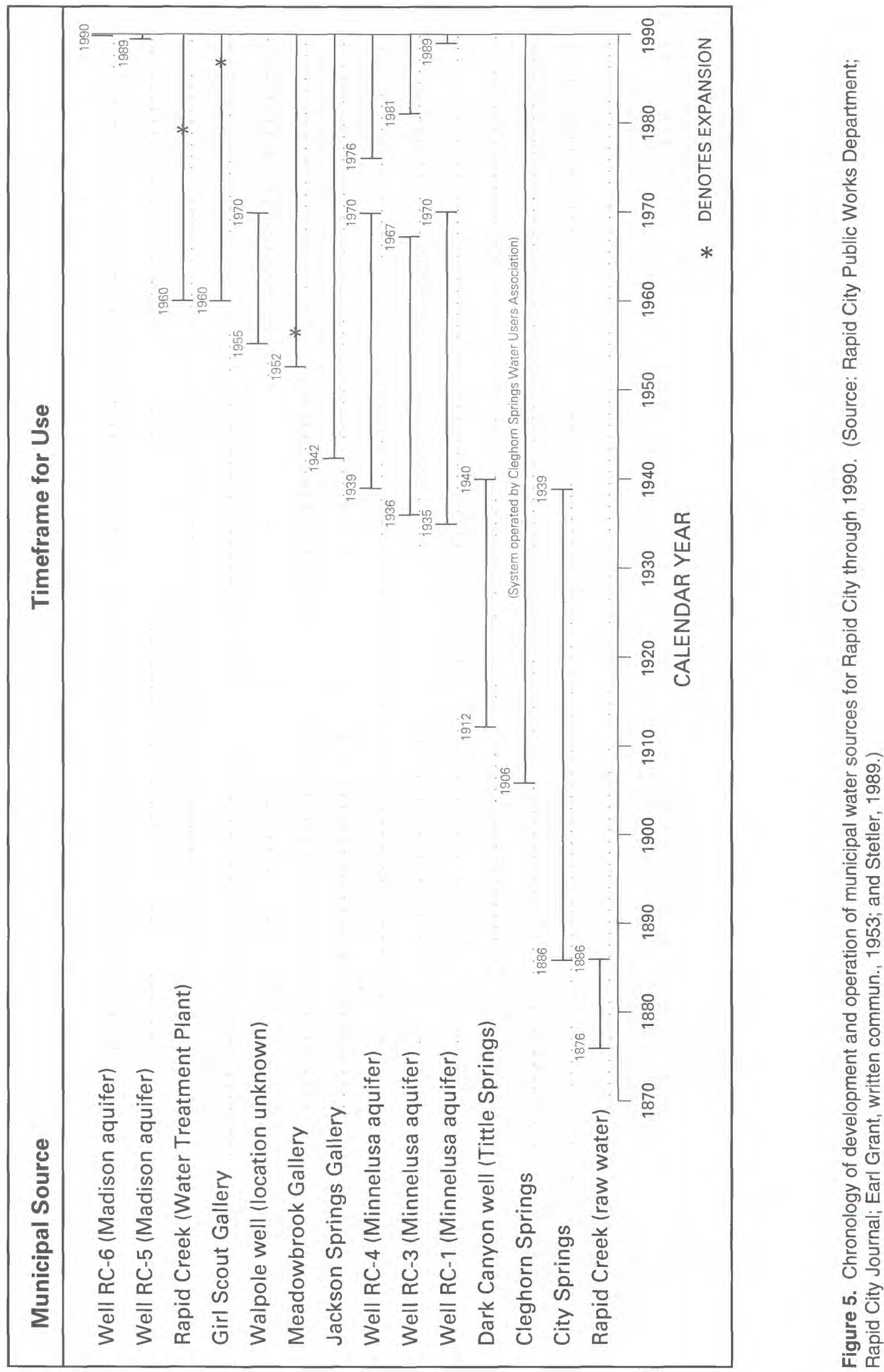
In response to the drought conditions, the City initiated a well-drilling program in 1935 to secure additional water supplies. Of the five bedrock wells drilled during this early effort, three were still in production during 1990 (figs. 2 and 5). Well RC-1 (fig. 2), as indicated from driller's logs and well-completion data, extends to the Deadwood aquifer; however, production is primarily from the Minnelusa aquifer (table 2). This well was used only for park watering between 1970 and 1989 , but was connected to the municipal supply in 1989 because of drought conditions and increasing demand (fig. 5). Well RC-3 is completed primarily in the Minnelusa aquifer but may penetrate the Madison aquifer by 20 to $40 \mathrm{ft}$, and well RC- 4 is completed only in the Minnelusa aquifer. Well RC-2 and an unnumbered well were drilled during 1936-41 but were abandoned (table 11). The "Walpole" well was used during 1955-70 (fig. 5).

The drought of the late 1980's produced a new period of expansion and acquisition of additional water supplies, including the purchase of water rights to natural flows in Rapid Creek from irrigators in Rapid Valley. During 1989-90, the City initiated a drilling program to complete additional wells in the Madison aquifer, thus increasing total water production and reducing dependence on streamflow, particularly that stored in Pactola Reservoir. Well RC-5 (fig. 2) is completed only in the Madison aquifer, as indicated from the driller's log and borehole geophysics. Well RC-6, which is located adjacent to City Springs, was completed in the Madison aquifer but may also be open to the Minnelusa aquifer. Five additional wells were completed in the Madison aquifer during 1991 (table 2) but were not in production during the period of this study. Annual production for WY 1987-90 from bedrock wells and other municipal sources is presented in table 3. Average annual production for the period used for hydrologic budgeting (WY 1988-89) is shown in figure 6. Monthly production records for WY 1987-90 are presented in table 12 in the Supplemental Information section.

Table 2. Selected information on Rapid City production wells

$[--$, no data $]$

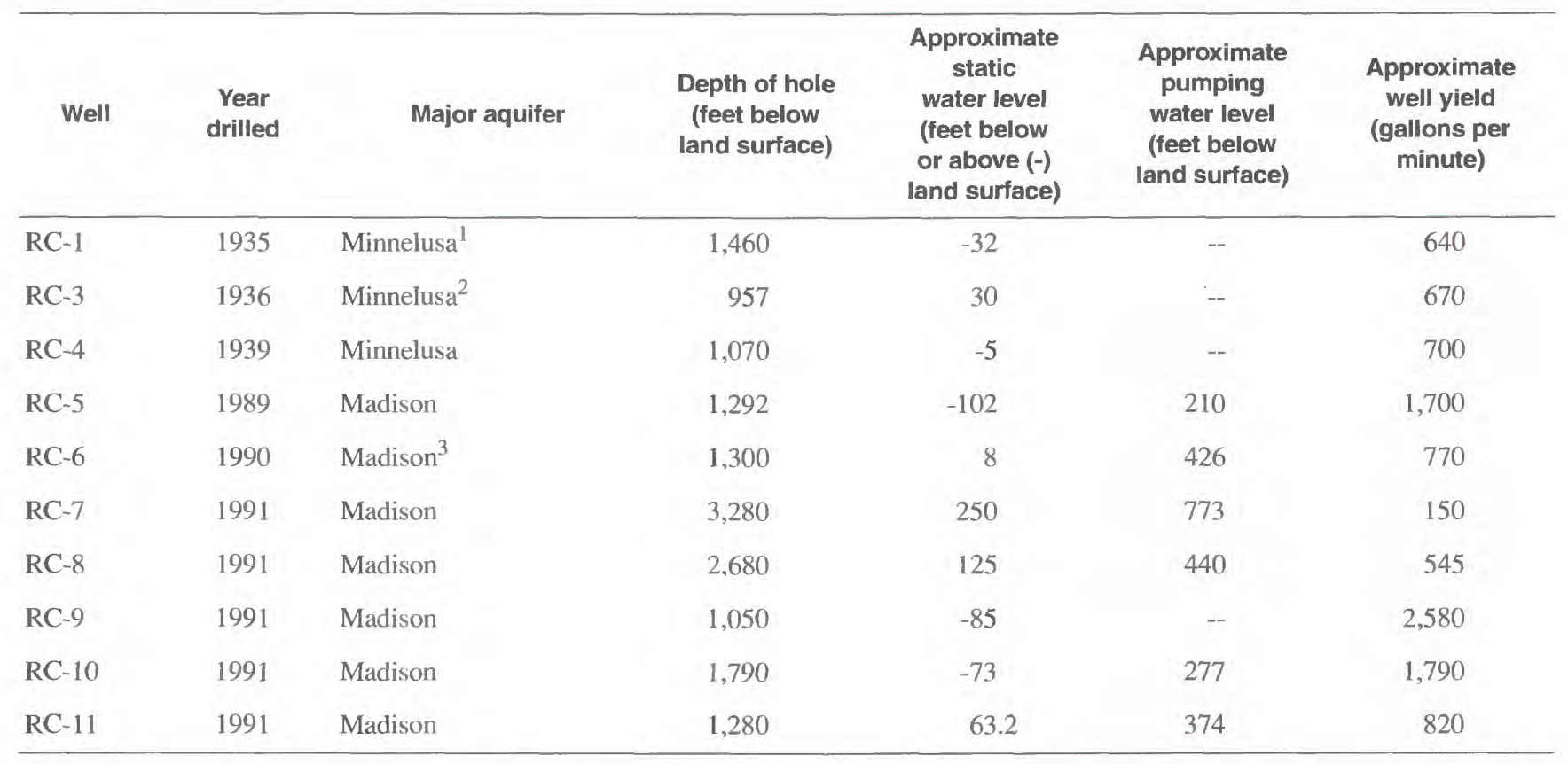

\footnotetext{
${ }^{1}$ May also produce from Madison and Deadwood aquifers.

${ }^{2}$ May also produce from Madison aquifer.

${ }^{3}$ May also produce from Minnelusa aquifer.
} 
Table 3. Annual water production, in acre-feet, for Rapid City, water years 1987-90

[Source: Rapid City Water Department (see table 12). All values reported to the nearest acre-foot for use in hydrologic budgets. --, well not yet constructed]

\begin{tabular}{|c|c|c|c|c|c|}
\hline \multirow[b]{2}{*}{ Source } & \multicolumn{5}{|c|}{ Water year } \\
\hline & 1987 & 1988 & 1989 & 1990 & $\begin{array}{c}1988-89 \\
\text { mean }^{1}\end{array}$ \\
\hline \multicolumn{6}{|l|}{ Finished water } \\
\hline Jackson Springs Gallery & 4,201 & 4,581 & 4,128 & 4,501 & 4,355 \\
\hline Meadowbrook Gallery & 1,992 & 2,489 & 1,708 & 2,332 & 2,099 \\
\hline Girl Scout Gallery & ${ }^{2} 366$ & ${ }^{2} 580$ & 1,182 & 876 & 881 \\
\hline RC-1 (Minnelusa ${ }^{3}$ well) & 0 & 0 & 61 & 191 & 30 \\
\hline RC-3 (Minnelusa ${ }^{3}$ well) & 429 & 402 & 362 & 466 & 382 \\
\hline RC-4 (Minnelusa well) & 670 & 668 & 67 & 723 & 368 \\
\hline RC-5 (Madison well) & -- & -- & - & 254 & 0 \\
\hline RC-6 (Madison ${ }^{3}$ well) & -- & -- & - & ${ }^{4} 0$ & \\
\hline Water Treatment Plant (Rapid Creek) & 3,064 & 5,737 & 2,049 & 511 & 3,893 \\
\hline Total $^{1}$ finished water & 10,722 & 14,457 & 9,558 & 9,854 & 12,008 \\
\hline \multicolumn{6}{|l|}{ Raw water (irrigation) } \\
\hline Arrowhead Golf Course & 164 & 265 & 149 & 149 & 207 \\
\hline Meadowbrook Golf Course & 139 & 193 & 142 & 110 & 168 \\
\hline Executive Golf Course & $\underline{25}$ & 37 & 29 & 26 & 33 \\
\hline Total $^{1}$ raw water & 328 & 494 & 320 & 285 & 407 \\
\hline
\end{tabular}

\footnotetext{
independent rounding.

${ }^{2}$ No production from July 10, 1987, to April 28, 1988, because of construction.

${ }^{3}$ Predominant source; however, well may also produce from other aquifer(s).

${ }^{4}$ First production during December 1990.
}

${ }^{1}$ Mean and total values may not be exact arithmetic mean of annual values or exact arithmetic total of individual values. respectively, because of

The Jackson Springs, Meadowbrook, and Girl Scout Galleries (fig. 2) were constructed by placing perforated, large-diameter pipe within excavations in the alluvial aquifer at a maximum depth of about $30 \mathrm{ft}$. A schematic showing typical construction of infiltration galleries is shown in figure 7 .

The Jackson Springs Gallery was constructed in 1942 and has a sustained production capacity of about $8 \mathrm{ft}^{3} / \mathrm{s}$ (fig. 8), which is equivalent to about $5.2 \mathrm{Mgal} / \mathrm{d}$. The Jackson Springs Gallery is the largest individual source of municipal water for Rapid City (fig. 6) and is operated with less daily variation than the Meadowbrook or Girl Scout Galleries (fig. 8). Production averaged about 4,355 acre-ft/yr during WY 1988-89 (table 3 ), or about $6 \mathrm{ft}^{3} / \mathrm{s}$ on a sustained basis.

The Meadowbrook Gallery was constructed in 1952 and was expanded in 1955 to its present production capacity of about $3.5 \mathrm{Mgal} / \mathrm{d}$. Production averaged about 2,099 acre-ft/yr during WY 1988-89 (table 3), or about $3 \mathrm{ft}^{3} / \mathrm{s}$ on a sustained basis.

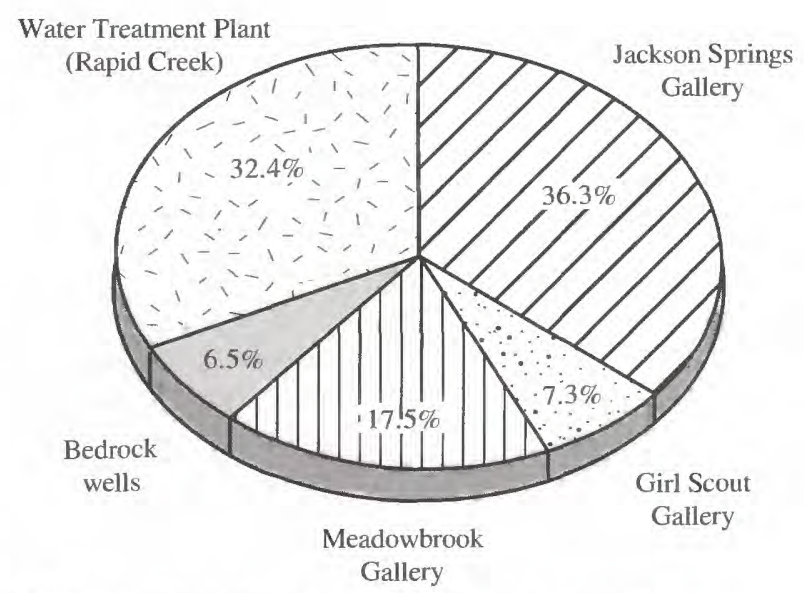

NOTE: Average annual production for all sources totaled 12,008 acre-feet.

Figure 6. Sources of finished municipal water for Rapid City during water years 1988-89 (excludes golf course irrigation). (Source: Rapid City Public Works Department.) 


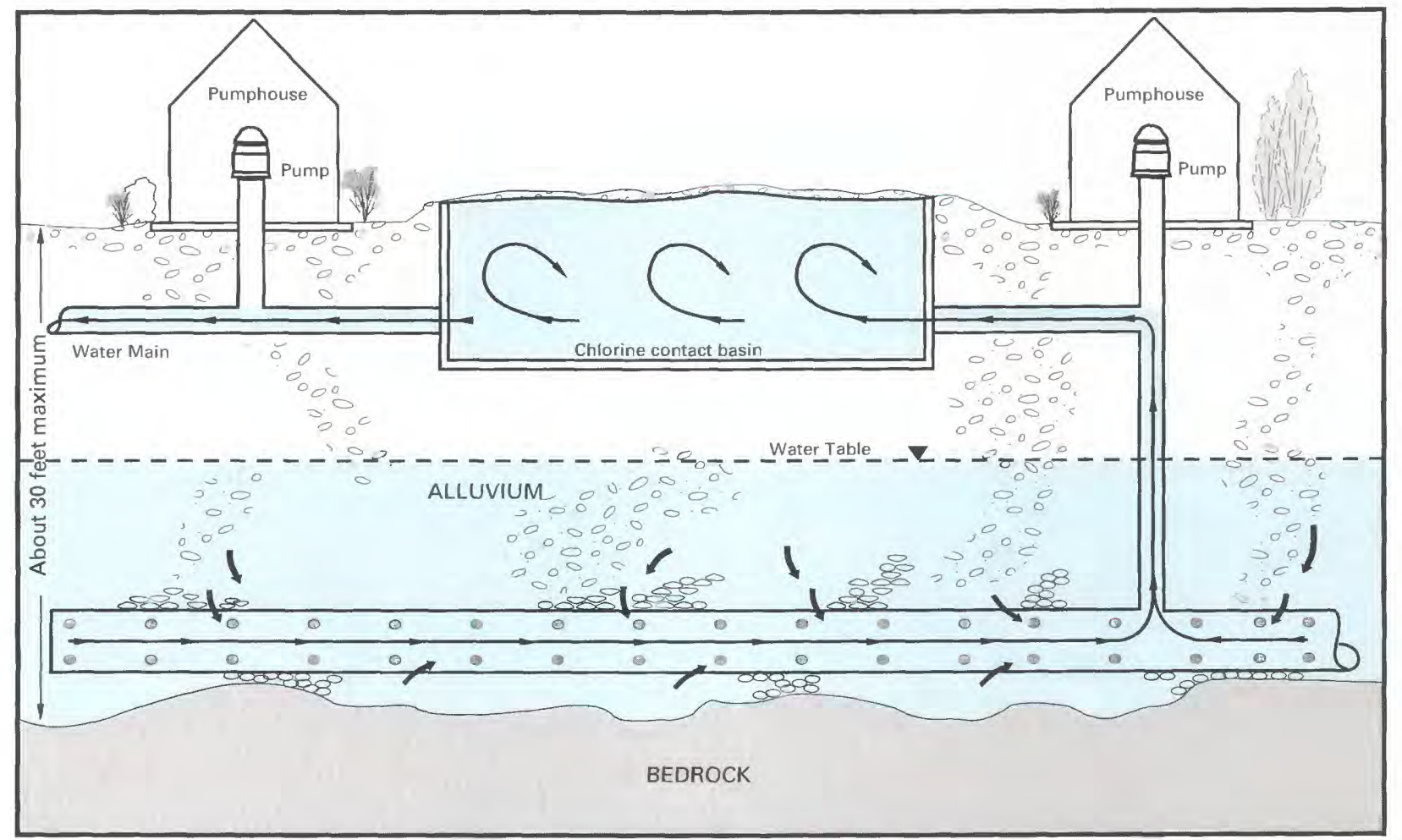

NOT TO SCALE

Figure 7. Schematic cross section showing typical construction of infiltration galleries along Rapid Creek.

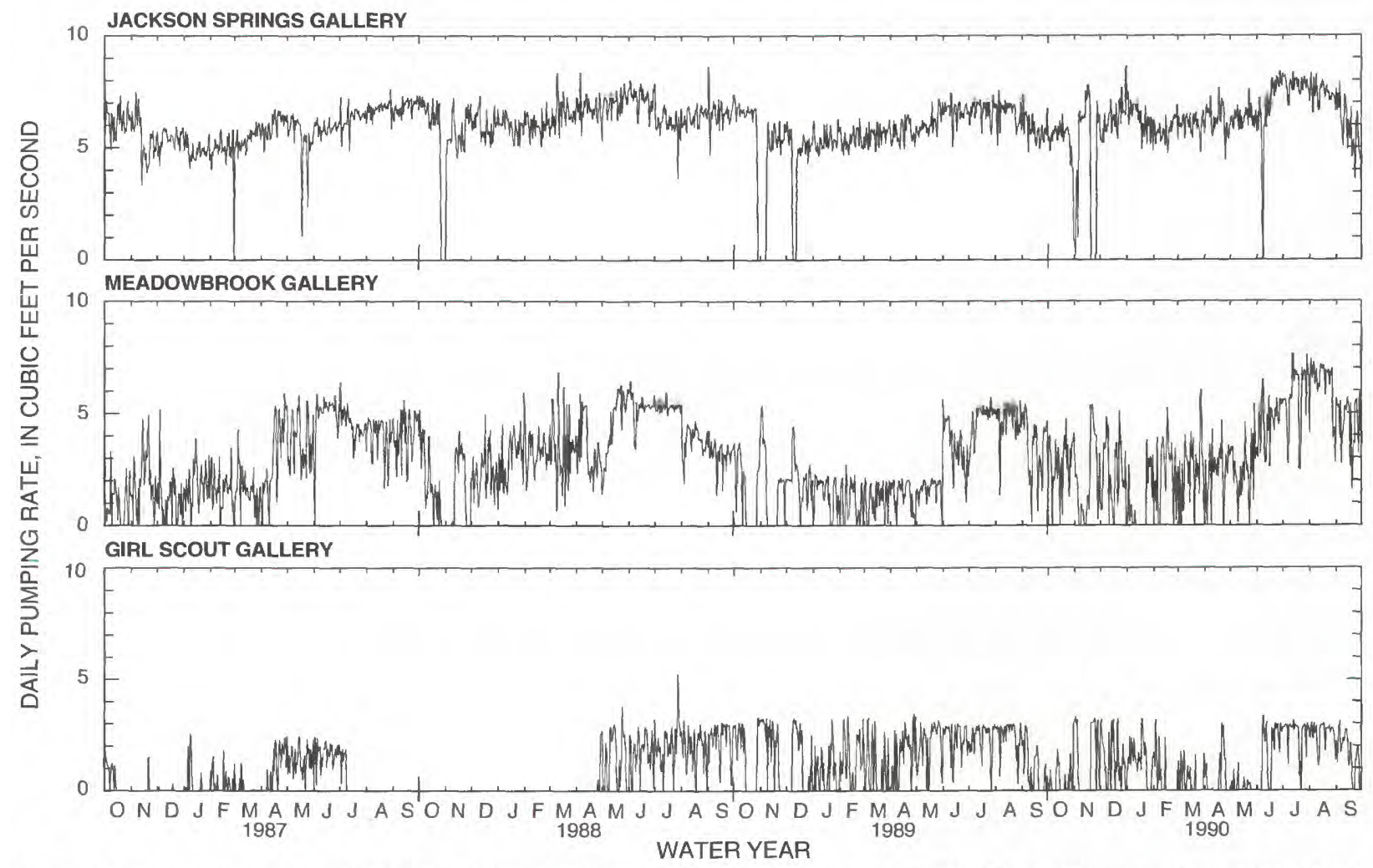

Figure 8. Daily pumping rate for Rapid City infiltration galleries for water years 1987-90. (Source: Rapid City Public Works Department.) 
The Girl Scout Gallery was constructed in 1960 and expanded during 1987-88 to its present production capacity of about $1.5 \mathrm{Mgal} / \mathrm{d}$. Production during WY 1988-89 was limited because of construction activities and averaged only 881 acre-ft/yr (table 3 ), or about $1.2 \mathrm{ft}^{3} / \mathrm{s}$ on a sustained basis.

The Water Treatment Plant (fig. 2) was constructed in 1960 and expanded in 1979 to its present production capacity of about $32 \mathrm{Mgal} / \mathrm{d}$. The plant draws water directly from Rapid Creek and operates seasonally to meet peak summer demand, which depends primarily on demand for lawn watering. An annual maximum of 5,737 acre- $\mathrm{ft}$ of treated water was produced during WY 1988 (table 3), which was an extreme drought year. Production averaged 3,893 acre-ft/yr during WY 1988-89 (table 3).

In 1988, the Rapid City Public Works Department, Water Division, supplied water to about 14,750 users, representing an estimated population of 57,000 residents. This total included about 6,600 residents of Ellsworth Air Force Base (Rodger A. Kruger, Rapid City Public Works Department, Water Division, oral commun., 1989). Annual production of the Water Division increased from about 2,650 acre-ft in 1943, when recordkeeping began, to about 10,000 acre-ft in 1990 (fig. 9). The maximum annual production of 14,460 acre-ft occurred during the drought of 1988. Daily demand during 1988 ranged from about $10 \mathrm{Mgal} / \mathrm{d}$ during the winter to about $35 \mathrm{Mgal} / \mathrm{d}$ during the summer (Rapid City Public Works Department, 1987-90).

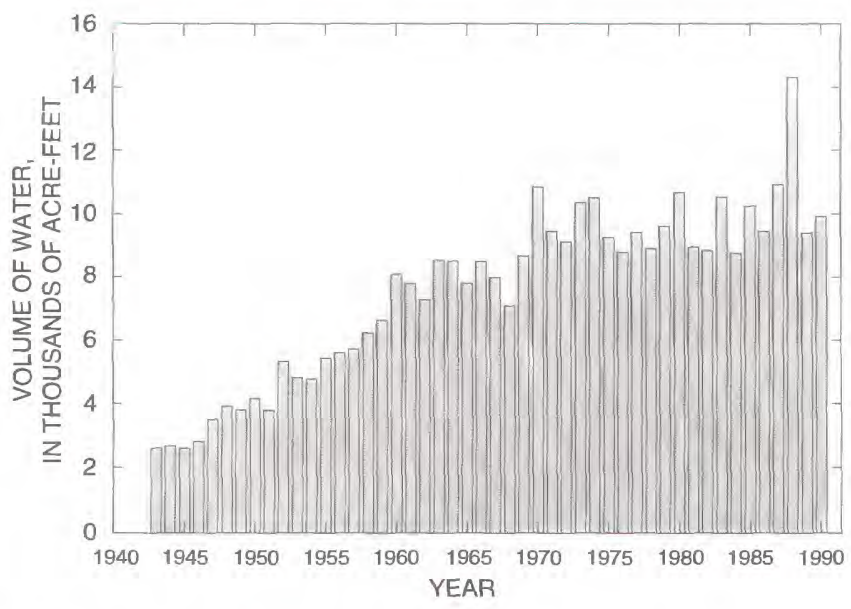

Figure 9. Municipal production of finished water (all sources) for Rapid City from 1943-90. (Source: Rapid City Public Works Department.)
The Rapid Valley Water Service Company supplied water to about 2,150 additional users, representing about 7,500 suburban residents living east of Rapid City. Water is drawn directly from Rapid Creek, from a shallow infiltration gallery adjacent to Rapid Creek, and from two deep wells (Lorraine Weimers, Rapid Valley Water Service Company, oral commun., 1992). This supply is supplemented by water from Rapid City during periods of peak demand.

\section{Irrigation}

The first water right on Rapid Creek was issued in 1877 for irrigation use on Leedy Ditch in west Rapid City (table 11). Bennett Ditch, Leedy Ditch, and Storybook Ditch (fig. 2) provide minor amounts of water (generally less than $2 \mathrm{ft}^{3} / \mathrm{s}$ each) for lawn and garden watering by residents. Rapid City reports withdrawals from Rapid Creek for irrigation of the Arrowhead, Meadowbrook, and Executive Golf Courses (table 3, fig. 2). Water is pumped from the creek and applied directly to these golf courses without passing through the City distribution system. Numerous ditches that are owned and operated by individual ditch companies divert water to agricultural users east of Rapid City. Irrigation demand, in combination with municipal demand, generally determines releases from Pactola Reservoir during the summer.

Irrigation interests hold annual rights to all stored water in excess of 7,000 acre-ft in Deerfield Reservoir. An additional amount in Pactola Reservoir (usually 7,000 acre-ft), which is determined by the Bureau of Reclamation at the beginning of each irrigation season (May 1 through September 30) is allocated for irrigation (Bureau of Reclamation, 1943, 1952a, $1952 b, 1961)$.

The total combined irrigation withdrawals from the ditches is difficult to calculate directly. The Bureau of Reclamation (1990) maintains records, by source, of water provided for irrigation, including natural flows in Rapid Creek upstream of Pactola Reservoir. Since 1958, the natural flows through Pactola Reservoir during the irrigation season have ranged from 4,256 acre- $\mathrm{ft}$ in 1986 to 19,394 acre-ft in 1964 . Combined releases to the Rapid Valley Water Conservancy District from storage in both Deerfield and Pactola Reservoirs have ranged from zero (for 9 different years) to 8,638 acre- $\mathrm{ft}$ in 1985 . Total diversions by the Conservancy District, including natural flows and releases from storage, have ranged from 4,383 acre-ft in 1986 to 25,575 acre- $\mathrm{ft}$ in 1981 (Bureau of Reclamation, 1990). 


\section{Reservoirs}

Three reservoirs (Canyon Lake, Deerfield, and Pactola) are located on the main stem of Rapid Creek. Canyon Lake was constructed in the 1930's by the Civilian Conservation Corps for recreational and aesthetic purposes only. The dam was destroyed by the 1972 flood and reconstructed in the late 1970's.

Canyon Lake has less than 150 acre-ft of storage (Stewart and others, 1989) and functions as a passthrough reservoir. Deerfield and Pactola Reservoirs are operated on a pooled-storage basis. Monthend usable contents of Deerfield and Pactola Reservoirs through 1990 are shown in figure 10.

Construction of Deerfield Dam, an earthfill structure, began July 7, 1942. Storage in Deerfield Reservoir, which is for municipal water supply, irrigation, and recreation, began December 3, 1945, and the facilities were completed by 1947 (U.S. Water and Power Resources Service, 1981). Active capacity is 15,500 acre- $\mathrm{ft}$ and dead storage is 150 acre- $\mathrm{ft}$.

Surcharge capacity (capacity above the crest of the spillway) is 26,660 acre- $\mathrm{ft}$ (Bureau of Reclamation, 1985b). The reservoir usually is maintained at or near capacity.

Construction of Pactola Dam, also an earthfill structure, began November 25, 1952, and storage began August 1956 (U.S. Water and Power Resources Service, 1981). The multipurpose dam was built to provide municipal water for Rapid City and the Rapid Valley Water Service Company, irrigation water for the Rapid Valley Water Conservancy District, flood control on Rapid Creek, fish and wildlife benefits, and waterbased recreation. The need for water at Ellsworth Air Force Base provided additional justification for construction of Pactola Dam. Active capacity is 54,960 acre- $\mathrm{ft}$, and combined dead and active storage is 1,017 acre-ft. In addition to water-supply storage, Pactola Reservoir provides 43,057 acre-ft of exclusive flood-control storage and 41,892 acre-ft of surcharge capacity (Bureau of Reclamation, 1988). During nonirrigation months (October through April), a minimal conservation release of $15 \mathrm{ft}^{3} / \mathrm{s}$ typically is maintained from Pactola Reservoir (Bureau of Reclamation, 1989).

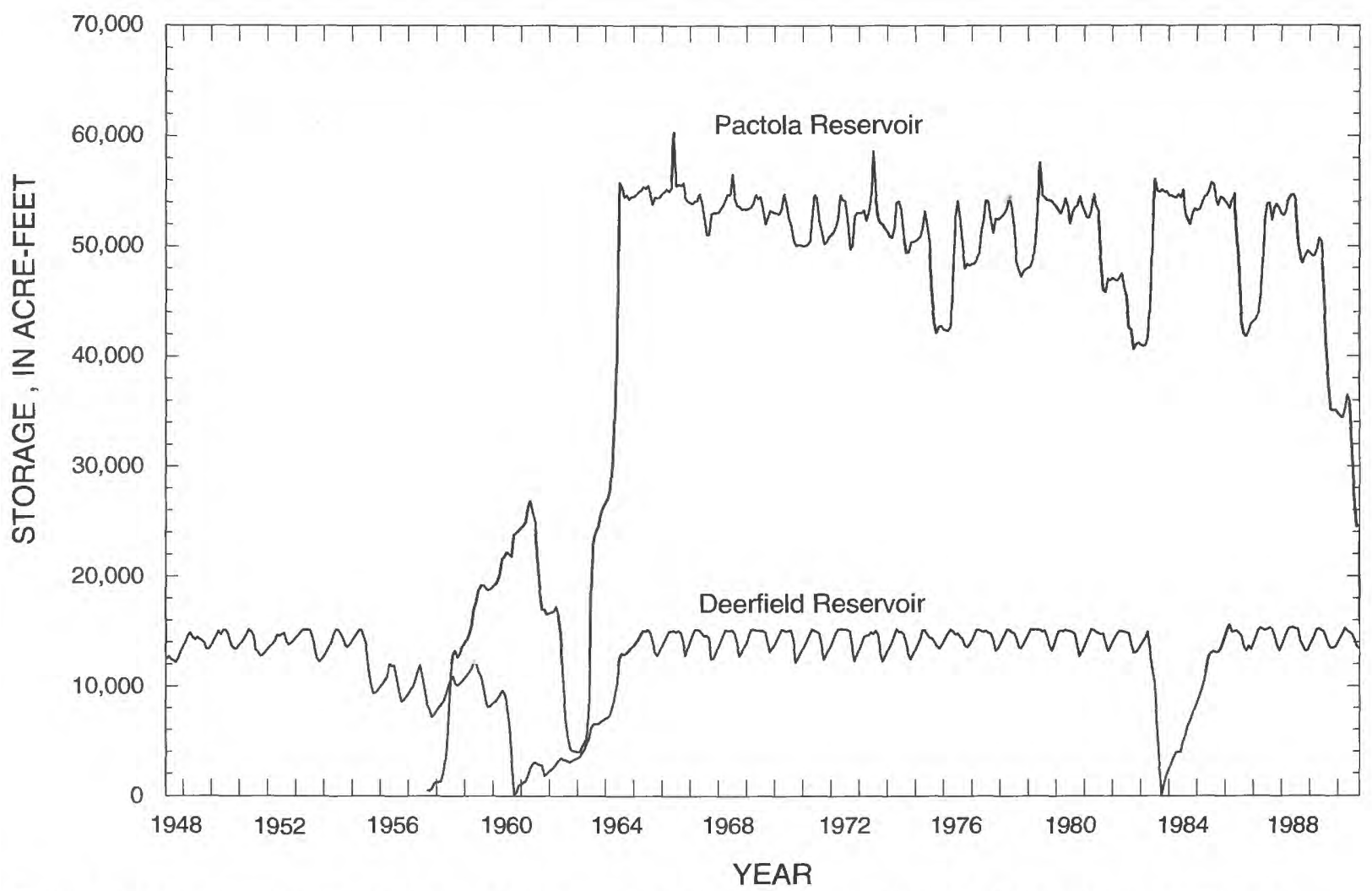

Figure 10. Monthend usable contents of Deerfield and Pactola Reservoirs though 1990 (Source: Bureau of Reclamation). 


\section{STUDY DESIGN AND METHODS}

The study was designed to quantify groundwater and surface-water interactions along Rapid Creek and identify sources contributing water to the City's three infiltration galleries. From the onset, there was a concern that streamflow gaging alone might not yield conclusive results because gallery pumping rates generally are small relative to the flow of Rapid Creek. Thus, the study included measurement of water levels in observation wells and collection of hydrochemical data to differentiate and identify potential sources of water.

Data-collection activities were focused on October through December each year because effects of variables such as stormflow and evaporation were minimized, and low, stable flows in Rapid Creek improved the probability that effects of gallery pumping could be directly measured. Gallery cycling, which consisted of alternately maximizing and ceasing gallery pumping for extended numbers of days (fig. 11), was performed to stress the hydrologic system for studies of interactions between the galleries, Rapid Creek, and its alluvial aquifer. These studies were conducted over three fall seasons to avoid the possibility that an anomalous year of flow conditions or measurements would yield unrepresentative results.

\section{Data-Collection Networks}

The data-collection networks for the study consisted of streamflow-gaging stations, observation wells, and water-quality sampling sites. Seventeen continuous-record, streamflow-gaging stations operated within the study area were considered, with WY 1988-89 being the most intensive period of data collection. Artificial controls were installed at many sites, especially in the smaller channels, to improve accuracy. A summary of gaging-station information is presented in table 4, and locations of gaging stations are shown in figure 2. Daily streamflow data were published annually in Water Resources Data, South Dakota, for WY 1987-90 (U.S. Geological Survey, 1988-91). Instantaneous streamflow measurements were made at various miscellaneous sites where minor flows occurred or water-quality samples were collected.
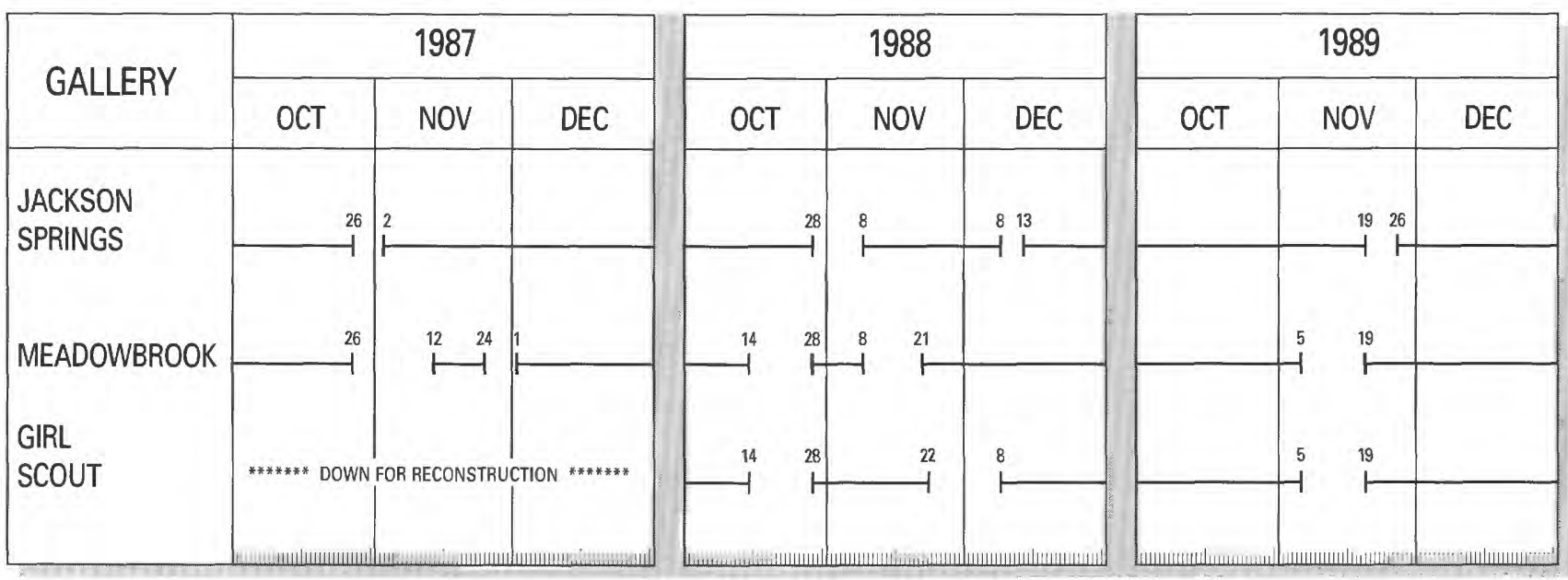

EXPLANATION

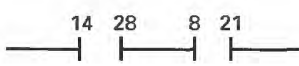

LINES INDICATE PUMPING PERIODS AND GAPS INDICATE SCHEDULED NONPUMPING PERIODS-Numbers indicate date on which pumping transition occurred

Figure 11. Schematic showing scheduled gallery cycling during October through December 1987-89. 
Table 4. Streamflow-gaging network used for study

[Type of control: A, artificial; NC. natural channel; MNC, modified natural channel]

\begin{tabular}{|c|c|c|c|c|}
\hline $\begin{array}{c}\text { Station } \\
\text { identification } \\
\text { number } \\
\text { (fig. 2) }\end{array}$ & Station name & $\begin{array}{c}\text { Type } \\
\text { of } \\
\text { control }\end{array}$ & $\begin{array}{l}\text { Period of } \\
\text { record used } \\
\text { (water } \\
\text { year) }\end{array}$ & $\begin{array}{c}\text { Drainage } \\
\text { are? } \\
\text { (square } \\
\text { miles) }\end{array}$ \\
\hline 06411500 & Rapid Creek below Pactola Dam & A & $1988-90$ & 320 \\
\hline 06412200 & Rapid Creek above Victoria Creek, near Rapid City & $\mathrm{NC}$ & $1989-90$ & 355 \\
\hline 06412600 & Cleghorn Springs Main Channel at Fish Hatchery, at Rapid City & A & $1988-90$ & $\left({ }^{1}\right)$ \\
\hline 06412700 & Cleghorn Springs South Channel at Fish Hatchery, at Rapid City & A & $1988-90$ & $\left({ }^{1}\right)$ \\
\hline 06412800 & Cleghorn Springs North Channel at Fish Hatchery, at Rapid City & A & $1988-90$ & $\left({ }^{1}\right)$ \\
\hline 06413300 & Leedy Ditch at headgate below Canyon Lake Dam, at Rapid City & A & $1988-290$ & $\left({ }^{1}\right)$ \\
\hline 06413550 & Leedy Ditch at mouth, at Rapid City & A & $1988-{ }^{2} 90$ & $(1)$ \\
\hline 06413570 & Rapid Creek above Jackson Boulevard, at Rapid City & A & $1988-{ }^{2} 90$ & 391 \\
\hline 06413650 & Lime Creek at mouth, at Rapid City & A & $1988-90$ & 10.1 \\
\hline 06413660 & Storybook Ditch at headgate, at Rapid City & $\mathrm{MNC}$ & ${ }^{2} 1988-{ }^{-2}-90$ & $\left({ }^{1}\right)$ \\
\hline 06413670 & Storybook Ditch at mouth, at Rapid City & A & $1988-{ }^{2} 90$ & $\left({ }^{1}\right)$ \\
\hline 06413700 & Rapid Creek above Water Treatment Plant, at Rapid City & $\mathrm{NC}$ & $1988-{ }^{2} 90$ & 404 \\
\hline
\end{tabular}

\footnotetext{
${ }^{1}$ No drainage area determined (spring or ditch).

${ }^{2}$ Incomplete year of record.
}

Water levels were measured during WY 1987-89 in 32 observation wells completed in the alluvial aquifer, predominantly near the infiltration galleries (table 5). Measurements also were made at one access point to the Jackson Springs Gallery and two access points to the Meadowbrook Gallery. Locations of observation wells are shown in subsequent sections on detailed site maps of the gallery areas. Water levels were measured intermittently (with an emphasis on gallery cycling periods) using steel and electric tapes. Four wells near the Water Treatment Plant were instrumented and monitored to determine aquifer response to changes in streamflow in an area not influenced by gallery pumping. Water-level measurements in wells, galleries, and streams were made relative to measuring points with altitudes established by leveling from known bench marks. Water-level data are presented in tables 13-16 in the Supplemental Information sertion.

Water-quality samples were collected at 31 sites (table 6, fig. 12). Sampling consisted primarily of field measurements of dissolved gases (oxygen and nitrogen) and collection of samples for analysis of unstable isotopes of radium and stable isotopes of oxygen and hydrogen. 
Table 5. Observation wells used for study

[Method constructed: B, bored by hollow-stem auger; D, dug by backhoe; G, access point to gallery; --, no data]

\begin{tabular}{|c|c|c|c|c|c|c|c|}
\hline Location & Well name & $\begin{array}{c}\text { Station } \\
\text { identification } \\
\text { number }\end{array}$ & $\begin{array}{c}\text { Land- } \\
\text { surface } \\
\text { datum } \\
\text { (feet above } \\
\text { sea level) }\end{array}$ & $\begin{array}{c}\text { Well } \\
\text { depth of } \\
\text { (feet } \\
\text { below } \\
\text { land } \\
\text { surface) }\end{array}$ & $\begin{array}{l}\text { Method } \\
\text { con- } \\
\text { structed }\end{array}$ & \multicolumn{2}{|c|}{$\begin{array}{c}\text { Depth to water } \\
\text { (feet below } \\
\text { land surface) }\end{array}$} \\
\hline \multirow[t]{4}{*}{ Jackson-Cleghorn } & CS-1 & 440328103190501 & $3,384.39$ & 11 & B & 5.04 & 7.92 \\
\hline & $\mathrm{CS}-2$ & 440328103190502 & $3,383.81$ & 18 & B & 4.55 & 8.13 \\
\hline & CS-3 & 440328103190503 & 3.383 .75 & 20 & B & 4.79 & 7.48 \\
\hline & West manhole & 440327103180502 & $3,386.80$ & -- & $\mathrm{G}$ & 5.03 & 10.25 \\
\hline \multirow[t]{9}{*}{ Meadowbrook } & MBN-1 & 440344103163001 & $3,320.66$ & 20 & B & 5.46 & 14.88 \\
\hline & MBN-6 & 440344103163005 & $3,319.53$ & 20 & B & 5.04 & 14.66 \\
\hline & MBN-7 & 440344103163006 & $3,319.14$ & 20 & B & 4.96 & 14.75 \\
\hline & MBN-8 & 440344103163007 & $3,314.33$ & 15.2 & D & 1.38 & 10.47 \\
\hline & MBN-9 & 440344103163008 & $3,319.02$ & 13.7 & $\mathrm{D}$ & 4.38 & 12.53 \\
\hline & MBN-10 & 440344103163009 & $3,321.33$ & 15.5 & D & 6.71 & 14.07 \\
\hline & PH4 & 440343103163002 & 3.320 .85 & -- & $\mathrm{G}$ & 6.05 & 16.39 \\
\hline & PH5 & 440343103163001 & $3,324.07$ & -- & G & 9.09 & 22.49 \\
\hline & MBS-1 & 440342103163501 & $3,321.58$ & 17.5 & B & 6.48 & 17.50 \\
\hline \multirow{9}{*}{ Girl Scout } & GS-2 & 440320103161502 & $3,293.31$ & 20 & $\mathrm{~B}$ & .31 & 10.84 \\
\hline & GS-3 & 440320103161503 & $3,294.34$ & 19.5 & B & 3.98 & 13.89 \\
\hline & GS-4 & 440320103161504 & 3.294 .76 & 30.5 & $\mathrm{~B}$ & 4.53 & 15.85 \\
\hline & GS-5 & 440320103161505 & $3,294.97$ & 20 & B & 4.73 & 15.70 \\
\hline & GS-6 & 440320103161506 & $3,295.06$ & 30 & $\mathrm{~B}$ & 4.80 & 13.38 \\
\hline & GS-7 & 440320103161507 & $3,295.46$ & 20 & B & 5.19 & 12.08 \\
\hline & GS-8 & 440320103161508 & $3,294.12$ & 21 & B & 3.58 & 8.43 \\
\hline & GS-8A & 440320103161510 & $3,294.74$ & 18 & $\mathrm{~B}$ & 3.00 & 7.53 \\
\hline & GS-9 & 440320103161509 & $3,297.50$ & 28 & B & 5.25 & 11.54 \\
\hline \multirow[t]{4}{*}{ Water Treatment Plant } & WT-1 & 440304103161301 & $3,275.71$ & 13.5 & B & 4.21 & 5.33 \\
\hline & WT-2 & 440304103161302 & $3,275.94$ & 15 & B & 4.34 & 5.50 \\
\hline & WT-3 & 440304103161503 & $3,277.58$ & 16.4 & $\mathrm{~B}$ & 5.74 & 6.38 \\
\hline & WT-4 & 440304103161504 & $3,277.52$ & 16.4 & $\mathrm{~B}$ & 5.37 & 6.02 \\
\hline
\end{tabular}

${ }^{1}$ Range of measured values between August 1987 and November 1989. 
Table 6. Water-quality-sampling sites

[Site type: SW, surface water: GW, ground water]

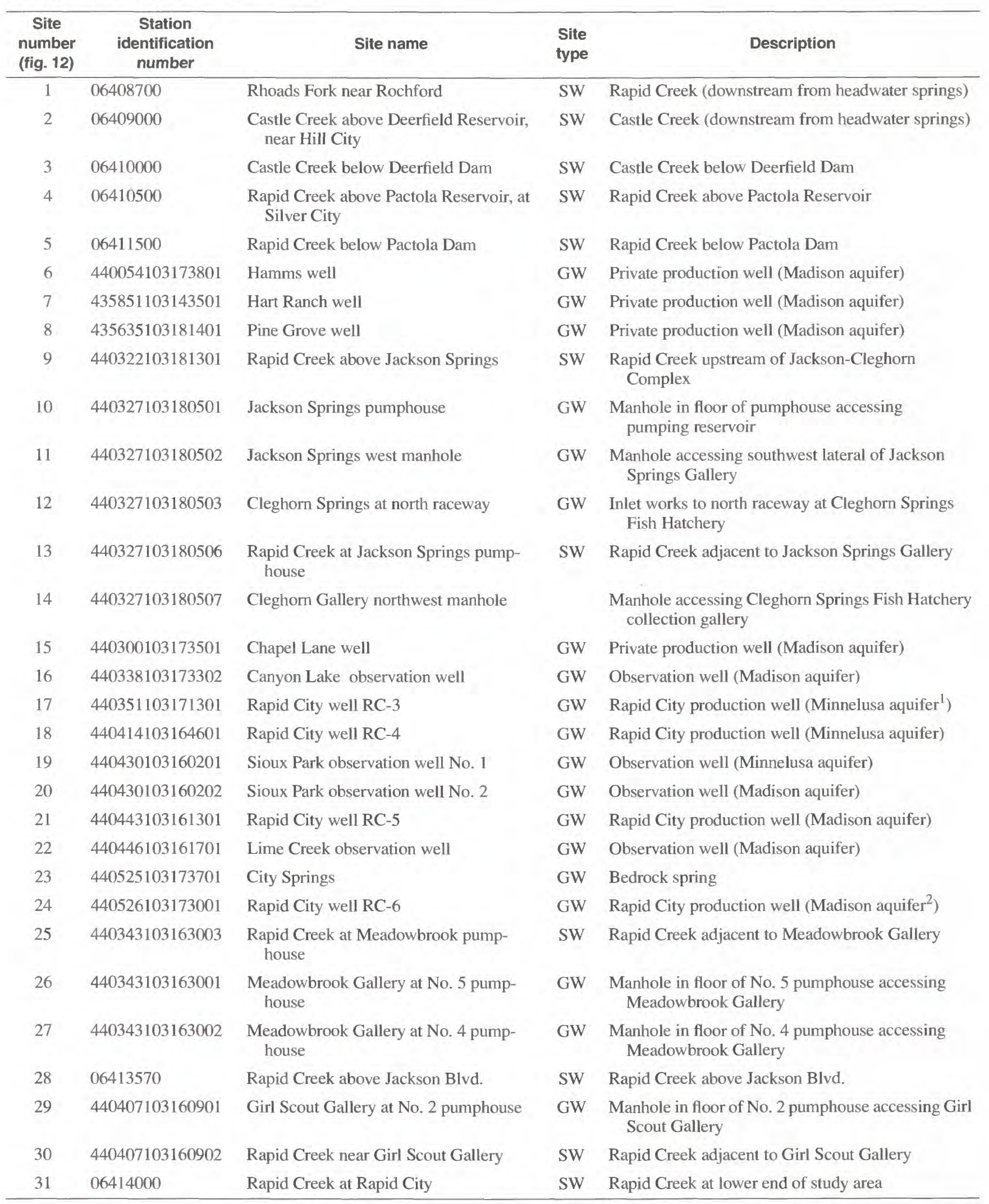

${ }_{1}^{1}$ May also produce from Madison aquifer.

${ }^{2}$ May also produce from Minnelusa aquifer. 


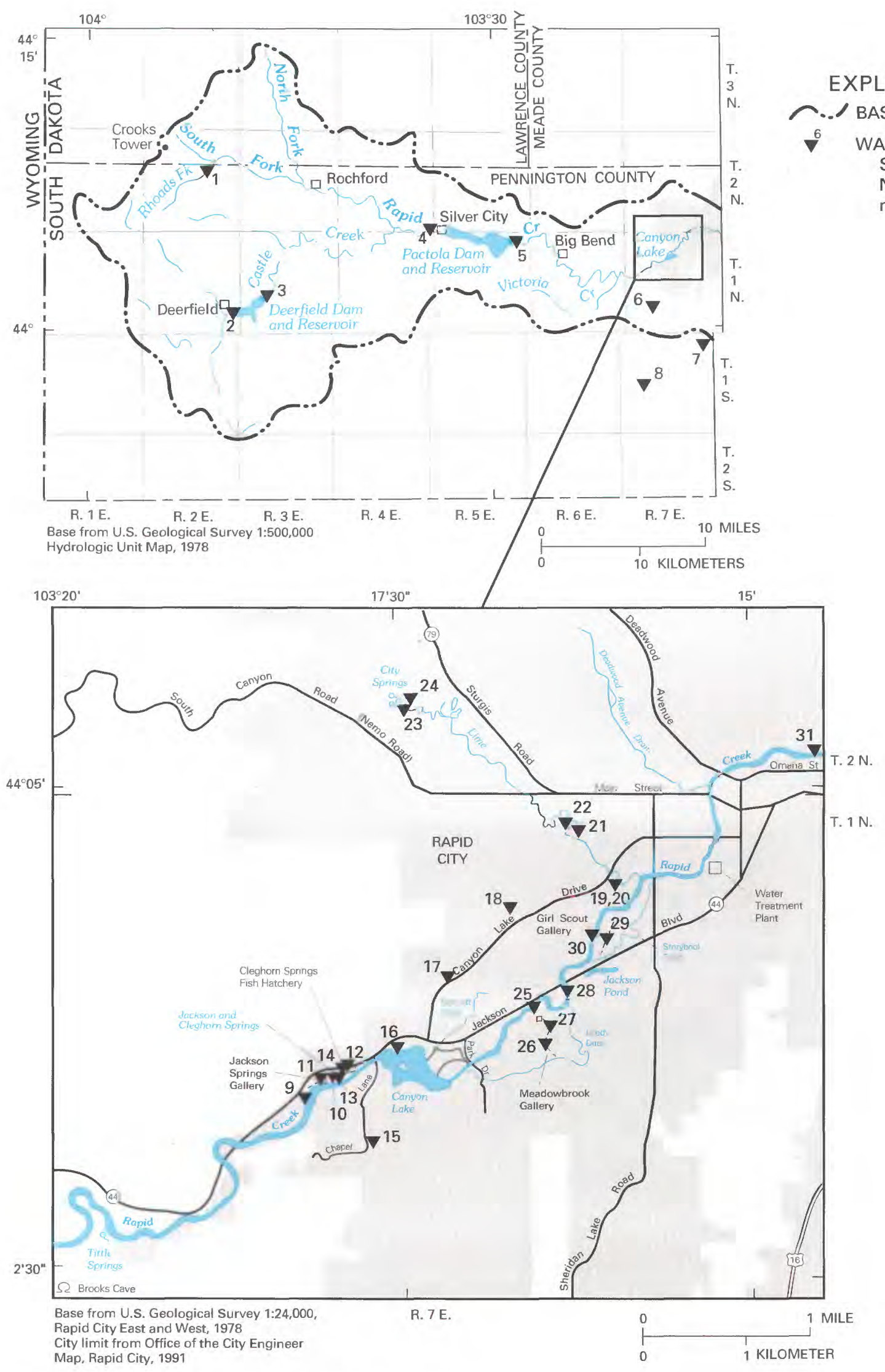

Figure 12. Location of water-quality sampling sites. 


\section{Hydrologic Budgets}

Various methods of hydrologic budgeting were used to quantify interactions between ground water and surface water. Hydrologic budgets were derived from the water-balance equation that states: Inflow Volume $=$ Outflow Volume \pm Change in Storage. For this study, changes in storage in the stream channel and alluvial aquifer are negligible relative to the annual flow volume of Rapid Creek.

"Control-volume analyses" (Streeter and Wylie, 1979) were used to quantify potential springflow from bedrock aquifers into the alluvial aquifer along Rapid Creek near the three infiltration galleries. The upper boundary of the control volume is defined as the surface of the alluvial aquifer and the free-water surface of the stream. The lower boundary is defined as the contact between the alluvial aquifer and the underlying bedrock unit. Although this underlying confining layer generally is much less permeable than the alluvial aquifer, the potential exists for upward or downw'rd leakage to occur through fractures or solution features in the confining layer. For convenience, the term springflow includes both diffuse leakage and concentrated discharge from an underlying bedrock aquifer into the control volume.

All components of flow into or out of the control volume, except bedrock leakage (springflow), car be measured or estimated. Springflow through the confining layer into the stream or alluvial aquifer system is computed as the residual; thus, it includes all of the errors associated with measurement or estimation of other terms in the equation. A positive sign on the residual indicates upward leakage. The following water-balance equation was applied using average annual values, in acre-feet per year, for WY 1988-89:

$$
R C_{i}+T_{i}+P_{s a}+A_{i}+S F_{i}=R C_{o}+W_{s a}+E T_{s a}+A_{o}
$$

where

$$
\begin{aligned}
R C_{i}= & \text { Rapid Creek inflow; } \\
T_{i}= & \text { tributary inflow; } \\
P_{s a}= & \text { precipitation on the stream and alluvial } \\
& \text { area; } \\
A_{i}= & \text { alluvial ground-water inflow; } \\
S F_{i}= & \text { upward leakage from bedrock aquifers } \\
& \text { (springflow), computed as a residual; }
\end{aligned}
$$

$$
\begin{aligned}
R C_{o}= & \text { Rapid Creek outflow; } \\
W_{s a}= & \text { withdrawals from surface and alluvial } \\
& \text { sources; } \\
E T_{s a}= & \text { evapotranspiration from the stream and allu- } \\
& \text { vial area; and } \\
A_{o}= & \text { alluvial ground-water outflow. }
\end{aligned}
$$

Solving for springflow:

$$
S F_{i} \pm e=R C_{o}+W_{s a}+E T_{s a}+A_{o}-R C_{i}-T_{i}-P_{s a}-A_{i}
$$

where $e$ is the error term associated with uncertainties in measurement or estimation of other terms in the equation.

Rapid Creek inflow $\left(R C_{i}\right)$ and outflow $\left(R C_{o}\right)$ and tributary inflow $\left(T_{i}\right)$ for several perennial tributaries were measured at continuous-record streamflowgaging stations (table 7). Tributary inflow from ungaged basins was estimated as 3 percent of annual precipitation on the drainage area using a regression equation presented by Driscoll (1987). Average annual precipitation on the stream and alluvial area $\left(P_{s a}\right)$ was estimated as 11.9 in. for WY 1988-89 using data for the Rapid City climatological station (index number 6947, U.S. Department of Commerce, 1987-90). That amount constitutes only about 70 percent of the long-term average precipitation for that station, which reflects extremely dry climatic conditions that prevailed during WY 1988-89. Average annual evap?transpiration $\left(E T_{s a}\right)$ from the stream and alluvial area was estimated as 30.4 in., by multiplying 0.7 times pan evaporation, using data for climatological stations at Pactola Reservoir (index number 6427) and at Cottonwood 2E (index number 1972), located about 70 mi east of Rapid City. Withdrawals from both surface and alluvial sources $\left(W_{s a}\right)$ were reported by the Rapid City Public Works Department, Water Division (table 3), or estimated as necessary. Significant figures for all terms generally were carried throughout waterbalance calculations and rounded after calculations were completed. 
Table 7. Annual flow, in acre-feet per year, for stations in streamflow-gaging network

$[--$, no data; ---, incomplete year of record]

\begin{tabular}{|c|c|c|c|c|c|}
\hline \multirow{2}{*}{$\begin{array}{c}\text { Station } \\
\text { identification } \\
\text { number }\end{array}$} & \multirow[b]{2}{*}{ Station name ${ }^{1}$} & \multicolumn{4}{|c|}{ Water year } \\
\hline & & 1988 & 1989 & 1990 & $\begin{array}{c}1988-89 \\
\text { mean }^{2}\end{array}$ \\
\hline 06412200 & Rapid Creek above Victoria Creek & -- & 24,840 & 20,820 & -- \\
\hline 06412500 & Rapid Creek above Canyon Lake & 24,690 & 19,150 & 13,750 & 21,920 \\
\hline 06412700 & Cleghorn Springs South Channel & 805 & 700 & 677 & 752 \\
\hline 06412800 & Cleghorn Springs North Channel & 754 & 703 & 661 & 728 \\
\hline 06412900 & Rapid Creek below Cleghorn Springs & 35,810 & 29,770 & 24,170 & 32,790 \\
\hline 06413200 & Rapid Creek below Park Drive & 33.760 & 26,780 & --- & 30,270 \\
\hline 06413570 & Rapid Creek above Jackson Blvd. & 33,260 & 25,490 & --- & 29,375 \\
\hline 06413650 & Lime Creek at mouth & 1,200 & 719 & 735 & 960 \\
\hline 06413660 & Storybook Ditch at headgate & $3_{2,300}$ & 1,700 & --- & 2,000 \\
\hline 06413670 & Storybook Ditch at mouth & 1,760 & 1,330 & -- & 1,545 \\
\hline 06413700 & Rapid Creek above Water Treatment Plant & 34,000 & 26,530 & --- & 30,265 \\
\hline 06413800 & Deadwood Avenue Drain at mouth & 1,860 & 1,740 & 1,750 & 1,800 \\
\hline 06414000 & Rapid Creek at Rapid City & 30,700 & 26,740 & 22,770 & 28,720 \\
\hline
\end{tabular}

\footnotetext{
${ }^{1}$ Some of the station names have been shortened.

${ }^{2}$ Mean values reported to the nearest acre-foot per year for use in hydrologic budgets.

${ }^{3}$ Part of year estimated.
}

Alluvial ground-water inflow $\left(A_{i}\right)$ and outflow $\left(A_{o}\right)$ were estimated for each control volume using values for transmissivity, hydraulic gradient, and alluvial width provided by Geibel (1991). Estimates for each cross section were derived using the equation:

$$
A=44.27 T I W
$$

where

$A=$ alluvial ground-water flow, in acre-feet per year;

$T=$ transmissivity (cross-sectional average), in feet squared per day;

$I=$ hydraulic gradient (dimensionless);

$W=$ width of cross section, in miles; and $44.27=$ a conversion factor.

Hydrologic budgets also were developed to quantify streamflow gains or losses from ground-water seepage for each of five subreaches of Rapid Creek between Pactola Reservoir and central Rapid City. This analysis provides information on the efficiency of Rapid Creek as a conveyance channel for water from Pactola Reservoir, the point of storage, to points of use in Rapid City. Considering only the stream channel as the control volume:

$$
R C_{i}+T_{i}+P_{s}+G W_{s}=R C_{o}+W_{s}+E_{s}
$$

where

$$
\begin{aligned}
R C_{i} & =\text { Rapid Creek inflow; } \\
T_{i} & =\text { tributary inflow; } \\
P_{s} & =\text { precipitation directly on stream; } \\
G W_{s} & =\text { ground-water seepage; } \\
R C_{o} & =\text { Rapid Creek outflow; } \\
W_{s} & =\text { withdrawals from surface sources; and } \\
E_{S} & =\text { evaporation directly from stream. }
\end{aligned}
$$


Average annual flow values for WY 1988-89, in acre-feet per year, were used for input. Rapid Creek inflow and outflow were measured at streamflow gages that delimited each subreach. Measured values for tributary inflow and for withdrawals from surface sources were used if available; estimated values were used as necessary. Tributary inflow from ungaged basins was estimated in the same manner as for equation 2. Precipitation on and evaporation from the stream are considered negligible relative to the other terms in the equation. A positive value for ground-water seepage $\left(\mathrm{GW}_{s}\right)$ indicates seepage from ground-water sources to the creek, and a negative value indicates seepage from the creek to ground water. Neglecting precipitation and evaporation and solving for ground-water seepage as the residual:

$$
G W_{s} \pm e=R C_{o}+W_{s}-R C_{i}-T_{i}
$$

where $e$ is again the error term.

An error analysis (Burkham and Dawdy, 1970) was performed for each solution of equations 2 and 5 in which springflow and ground-water seepage were computed as residuals. The standard error $\left(S E_{s}\right)$ for the error term $(e)$ associated with the residual is estimated by the following equation:

$$
S E_{s}=\left[\sum_{j=1}^{n} s_{i j}^{2}+\sum_{j=1}^{m} s_{o j}^{2}\right]^{0.5}
$$

where

$s_{i j}=$ standard error of the $j^{\text {th }}$ inflow component,

$s_{o j}=$ standard error of the $j^{\text {th }}$ outflow component,

$n=$ number of inflow components, and

$m=$ number of outflow components.

The error terms associated with each of the flow components are assumed to be uncorrelated. The error terms were estimated as follows:

measured Rapid Creek inflow $\left(R C_{i}\right)$ and outflow $\left(R C_{o}\right), \pm 3$ percent;

tributary inflow $\left(T_{i}\right), \pm 3$ percent for measured and \pm 50 percent for estimated;

estimated precipitation $\left(P_{s a}\right), \pm 25$ percent; withdrawals $\left(W_{s a}\right.$ and $\left.W_{s}\right), \pm 3$ percent for measured and \pm 50 percent for estimated;

estimated evapotranspiration $\left(E_{s a}\right), \pm 25$ percent; and estimated alluvial inflow $\left(A_{\mathrm{i}}\right)$ and outflow $\left(A_{\mathrm{o}}\right), \pm 50$ percent.

An estimate of the uncertainty associated with each solution of equations 2 and 5 is given by the standard error. The standard error generally is dominated by the error associated with streamflow measurements, in spite of low uncertainty ( \pm 3 percent), because the magnitude of annual streamflow is large compared to all other variables. A 5-percent error term probably would be used for most streamflow records; however, a 3-percent error term is justifiable for this study because of favorable gaging conditions and extraordinary efforts that were devoted to achieving a high level of gaging accuracy (artificial controls, frequent inspections, etc.).

\section{Hydrochemistry}

Hydrochemical information was used to identify potential sources of water at the three infiltration galleries and at Cleghorn Springs. The most useful chemical characteristics were distinct signatures produced by dissolved gases (oxygen and nitrogen), radionuclides, and stable isotopes of oxygen $\left({ }^{18} \mathrm{O}\right)$ and hydrogen $\left({ }^{2} \mathrm{H}\right.$; deuterium or $\left.\mathrm{D}\right)$.

In-situ measurements of dissolved-gas pressure were made at various creek, spring, well, and gallery sites with a Weiss Saturometer (Weitkamp and Katz, 1980). This instrument uses a membrane-diffusion method of gas-pressure measurement. Total gas pressure is read by a gage that represents hyperbaric pressure, or pressure differential between the dissolved gases in the water, and atmospheric barometric pressure. The nitrogen gas component is determined by subtracting the dissolved oxygen component (measured using a field dissolved oxygen meter) from total gas pressure.

Because of differences in depositional environments, aquifers may contain unique proportions of thorium and uranium and their resulting decay products of Ra-228 and Ra-226 (Thomas F. Kraemer, U.S. Geological Survey, oral commun., 1990). Because. Ra-228 and Ra-226 are slightly soluble in water, these isotopes can impart distinct signatures to water from different aquifers that are useful for identification (Michel and Moore, 1980). The field procedure for determination of radium-226 activity in stream and well water is described by Michel and others $(19 \& 1)$. The radon-emanation technique for measuring racium 
in the laboratory has been described by Broecker (1965) and by Mathieu (1988).

Stable isotopes of oxygen $\left({ }^{18} \mathrm{O}\right)$ and hydrogen (D) develop distinct signatures in waters of different origin because isotopes fractionate according to their masses. For example, when water evaporates, the lighter isotopes are present in greater abundance in the water vapor and the remaining water becomes enriched in the heavier isotopes (Drever, 1988). Stable isotopes are reported by convention as $\delta$ values relative to an international standard known as Vienna Standard Mean Ocean Water (VSMOW). These $\delta$ values are actually ratios given in units of parts per thousand (per mil and written \%o).

Distinct isotopic signatures of oxygen and hydrogen occur in water in the Black Hills area. The lightest water occurs on the west side of the Black Hills at higher altitudes, where $\delta^{18} \mathrm{O}$ ranges from -18 to $-16.5 \%$ and the heaviest water occurs on the east side at lower altitudes, where $\delta^{18} \mathrm{O}$ ranges from -15 to $-13 \%$ (Back and others, 1983). These signatures aid the interpretation of hydrologic flowpaths and identification of water sources. Analyses for radium and stable isotopes were performed in the U.S. Geological Survey laboratories in Reston, Virginia.

\section{GROUND-WATER AND SURFACE-WATER INTERACTIONS AT CITY INFILTRATION GALLERIES}

Interactions among Rapid Creek, the alluvial aquifer, and potential sources of springflow from bedrock aquifers near the City's three infiltration galleries were examined. Potential sources of springflow were quantified for three reaches of Rapid Creek (fig. 13) using control-volume analyses. Interactions between the galleries and the alluvial aquifer, and between the galleries and the creek also were examined. Hydrochemical interpretations of dissolved gases, radium isotopes, and stable isotopes of oxygen and hydrogen were performed, and used in combination with the physical information to identify potential sources of water to each gallery.

\section{Jackson Springs Gallery}

The Jackson Springs Gallery (fig. 14) is located immediately adjacent to Rapid Creek about $0.5 \mathrm{mi}$ upstream of Canyon Lake. This site was selected for installation of an infiltration gallery because of the large flows of Jackson Springs. When constructed in 1942 , the gallery was positioned over the snring, with one of the gallery laterals extending partly under Rapid Creek.

Cleghorn Springs, which is located inmediately adjacent to Jackson Springs, supplies water for the Cleghorn Springs Fish Hatchery and for the Cleghorn Springs Water Users Association (fig. 14). A gravityflow collection system captures the flow of Cleghorn Springs for delivery to the hatchery raceways.

Jackson and Cleghorn Springs may be separate springs that issue from a single source. Because of site development, the only visible flows from the collective springs are the outfall from the hatchery and seepage into Rapid Creek adjacent to the springs. The springs are collectively referred to as Jackson and Cleghorn Springs and the site is referred to as the JacksonCleghorn Complex. When referred to individually, Jackson Springs refers to springflow near the Jackson Springs Gallery and Cleghorn Springs refers to the outfall from the Cleghorn Springs Fish Hatchery.

\section{Control-Volume Analysis}

The Jackson-Cleghorn control volume is defined as that reach of Rapid Creek and its alluvial aquifer from gaging station 06412500, Rapid Creek above Canyon Lake, to station 06412900, Rapid Creek below Cleghorn Springs (fig. 13). The surface arsa of the alluvial aquifer in this reach is about 70 acres. The width, hydraulic gradient, and transmissivity of the alluvial aquifer are about $0.03 \mathrm{mi}, 0.0069 \mathrm{ft} / \mathrm{ft}$ (36 ft/mi), and $20,000 \mathrm{ft}^{2} / \mathrm{d}$, respectively, at the upstream extent and $0.12 \mathrm{mi}, 0.0069 \mathrm{ft} / \mathrm{ft}$, and $15,000 \mathrm{ft}^{2} / \mathrm{d}$, respectively, at the downstream extent of the reach (Geibel, 1991).

Thickness and saturated thickness of the alluvial aquifer were determined for seismic-refraction profiles A-A', B-B', and C-C' (fig. 15) near the Jackson Springs Gallery (fig. 14). The thickness of alluvial deposits overlying the Minnelusa Formation varies from less than $10 \mathrm{ft}$ to about $25 \mathrm{ft}$. The saturated thickness varies from zero to about $20 \mathrm{ft}$. The seismic-refraction analysis and water-level measurements in observation wells near the gallery (table 13) indicate the depth to the water table is about 5 to $10 \mathrm{ft}$. 


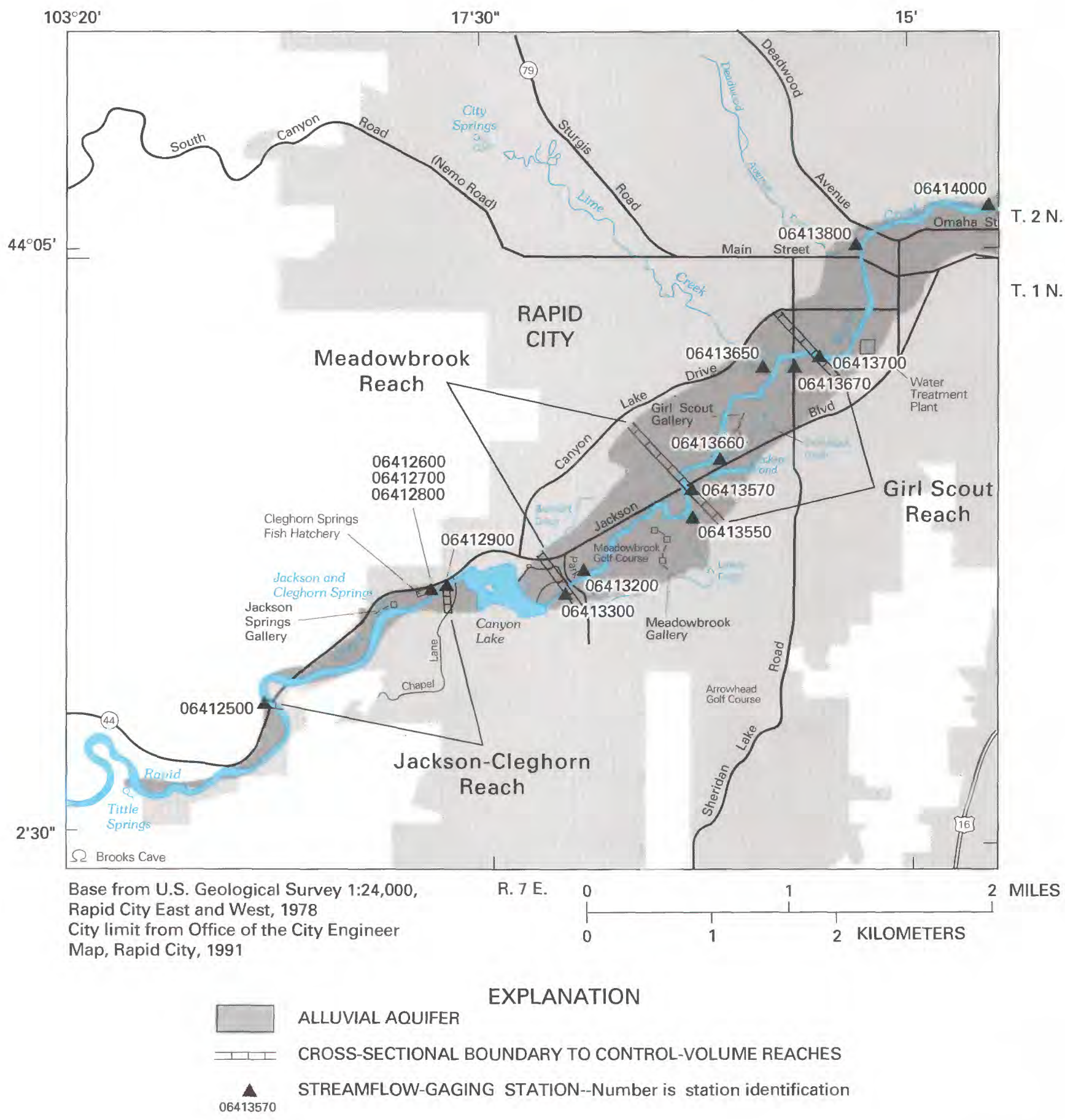

Figure 13. Approximate extent of alluvial aquifer and cross-sectional boundaries to control-volume reaches (extent of alluvial aquifer modified from Geibel, 1991). 


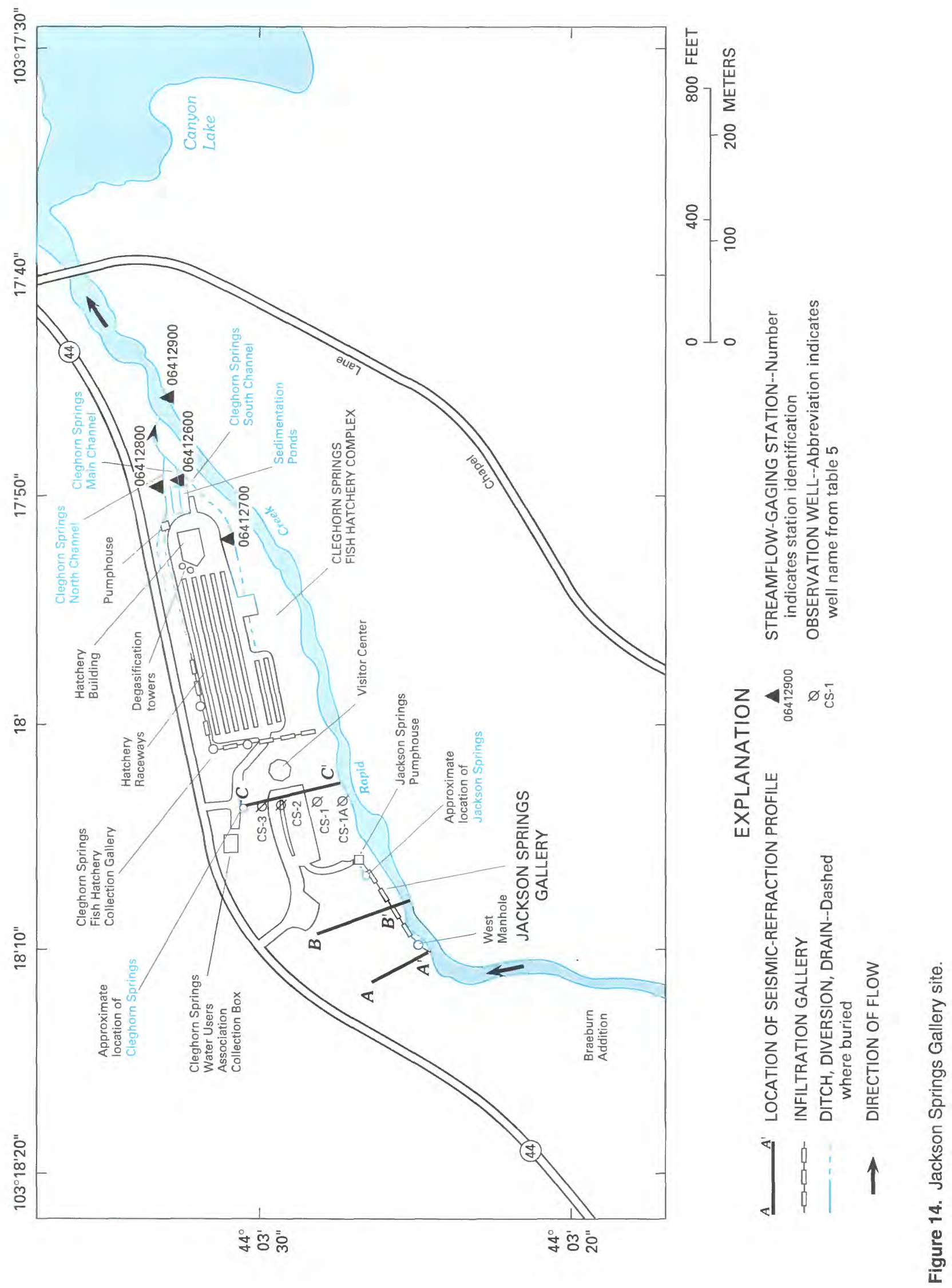




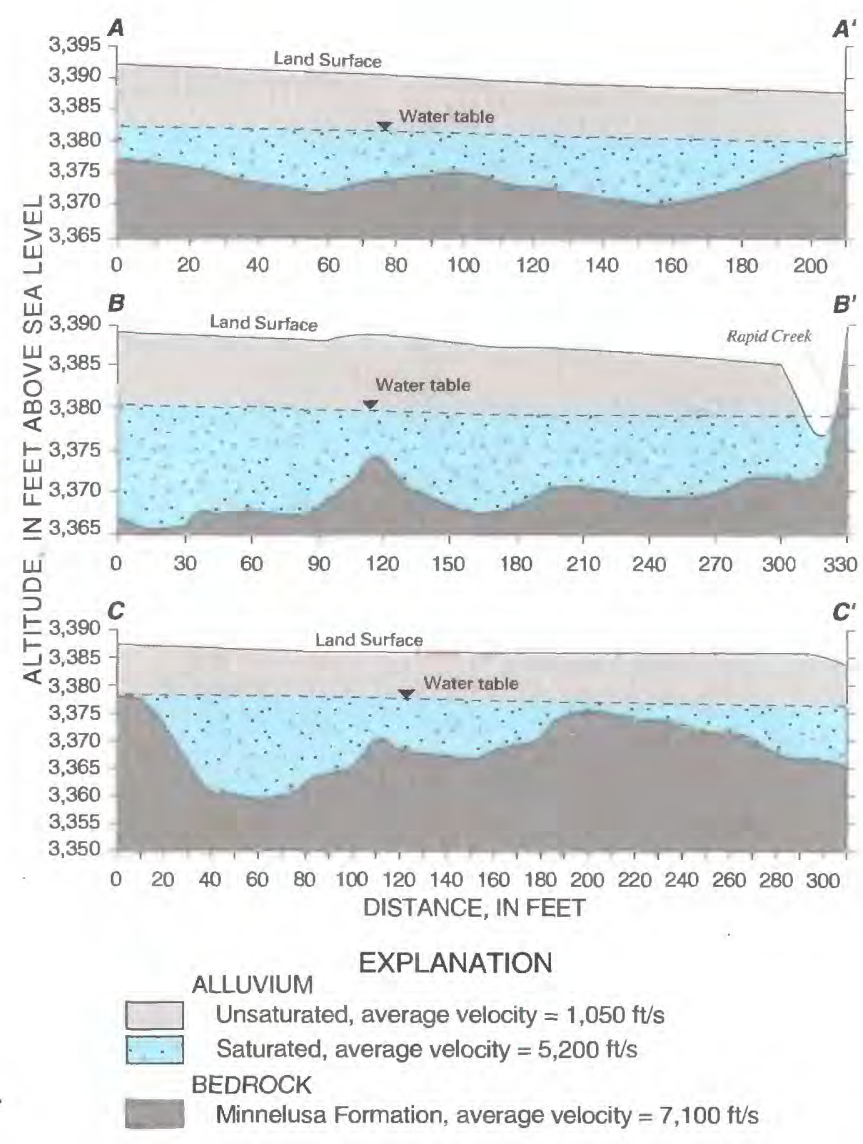

Figure 15. Geologic sections from interpretation of Jackson-Cleghorn seismic-refraction profiles (locations of sections shown in figure 14).

Springflow from Jackson and Cleghorn Springs was computed from the control-volume analysis to be about 15,600 acre- $\mathrm{ft} / \mathrm{yr}$ (equivalent to about $21.6 \mathrm{ft}^{3} / \mathrm{s}$ ) for WY 1988-89. Inflows and outflows to the control volume are schematically illustrated in figure 16 . Mean values of Rapid Creek inflow and outflow for WY 1988-89 were taken from table 7, and withdrawals from the Jackson Springs Gallery were taken from table 3. Annual withdrawals by the Cleghorn Springs Water Users Association were estimated as 50 acre-ft/yr and other values were estimated as previously described. Combined springflow was computed by substituting the following values, which are shown with associated error terms, into equation 2 :

$$
\begin{aligned}
R C_{i}= & 21,920( \pm 3 \text { percent }), \text { measured at station } \\
& 06412500 ; \\
T_{i}= & 130( \pm 50 \text { percent }), \text { estimated; } \\
P_{s a}= & 70( \pm 25 \text { percent }), \text { estimated; } \\
A_{i}= & 180( \pm 50 \text { percent }), \text { estimated; }
\end{aligned}
$$

$$
\begin{aligned}
R C_{o}= & 32,790( \pm 3 \text { percent }), \text { measured at station } \\
& 06412900 ; \\
W_{s a}= & 4,355( \pm 3 \text { percent }), \text { measured, plus } 50( \pm 50 \\
& \text { percent }), \text { estimated; } \\
E T_{s a}= & 180( \pm 25 \text { percent }), \text { estimated; and } \\
A_{o}= & 550( \pm 50 \text { percent }), \text { estimated. }
\end{aligned}
$$

Thus, springflow $\left(S F_{i}\right)=15,625$ or 15,600 acre-ft/yr (rounded).

Alluvial inflow $\left(A_{i}\right)$ and outflow $\left(A_{o}\right)$ were estimated by substituting the following values into equation 3:

$$
\begin{aligned}
T= & 20,000 \mathrm{ft}^{2} / \mathrm{d} \text { for inflow and } 15,000 \mathrm{ft}^{2} / \mathrm{d} \text { for } \\
& \text { outflow; } \\
I= & 0.0069 \text { (dimensionless); and } \\
W= & 0.03 \text { mi for inflow and } 0.12 \mathrm{mi} \text { for outflow. }
\end{aligned}
$$

Thus, alluvial inflow $\left(A_{i}\right)=180 \mathrm{acre}-\mathrm{ft} / \mathrm{yr}$; and alluvial outflow $\left(A_{o}\right)=550$ acre-ft/yr.

The standard error of the residual was computed by substituting the previous values and error estimates into equation 6. Thus, $S E_{S P R I N G}=1,228$ or.

$\pm 1,200 \mathrm{acre}-\mathrm{ft} / \mathrm{yr}$, which is small relative to the magnitude of the computed value of springflow into the reach $(15,600 \mathrm{acre}-\mathrm{ft} / \mathrm{yr})$. This indicates that the uncertainty associated with the estimate is small.

\section{Interactions with Alluvial Aquifer}

The Jackson Springs Gallery was cycled (on, off, on) four times (fig. 11) during the study to determine how pumping affects interactions with the alluvial aquifer and distribution of springflow and seepage into Rapid Creek. Changes in alluvial water levels for the observation-well network at the Jackson-Cleghorn Complex (fig. 14) during Oct. 22 through Nov. 13, 1987, are shown in figure 17. The water level in the west manhole of the gallery, during pumping periods, was as much as $5 \mathrm{ft}$ lower than the stage of Rapid Creek immediately adjacent to the manhole. This indicates that at least part of the gallery production is induced infiltration from the creek. Gallery pumping resulted in only about $2 \mathrm{ft}$ of drawdown in the observation wells (fig. 17), which are located about $200 \mathrm{ft}$ east of the gallery (fig. 14). Water levels rose rapidly when gallery pumps were turned off. Most of the recovery occurred within 1 day and full recovery occurred within 2 days. 
INFLOWS, IN ACRE-FEET

PER YEAR

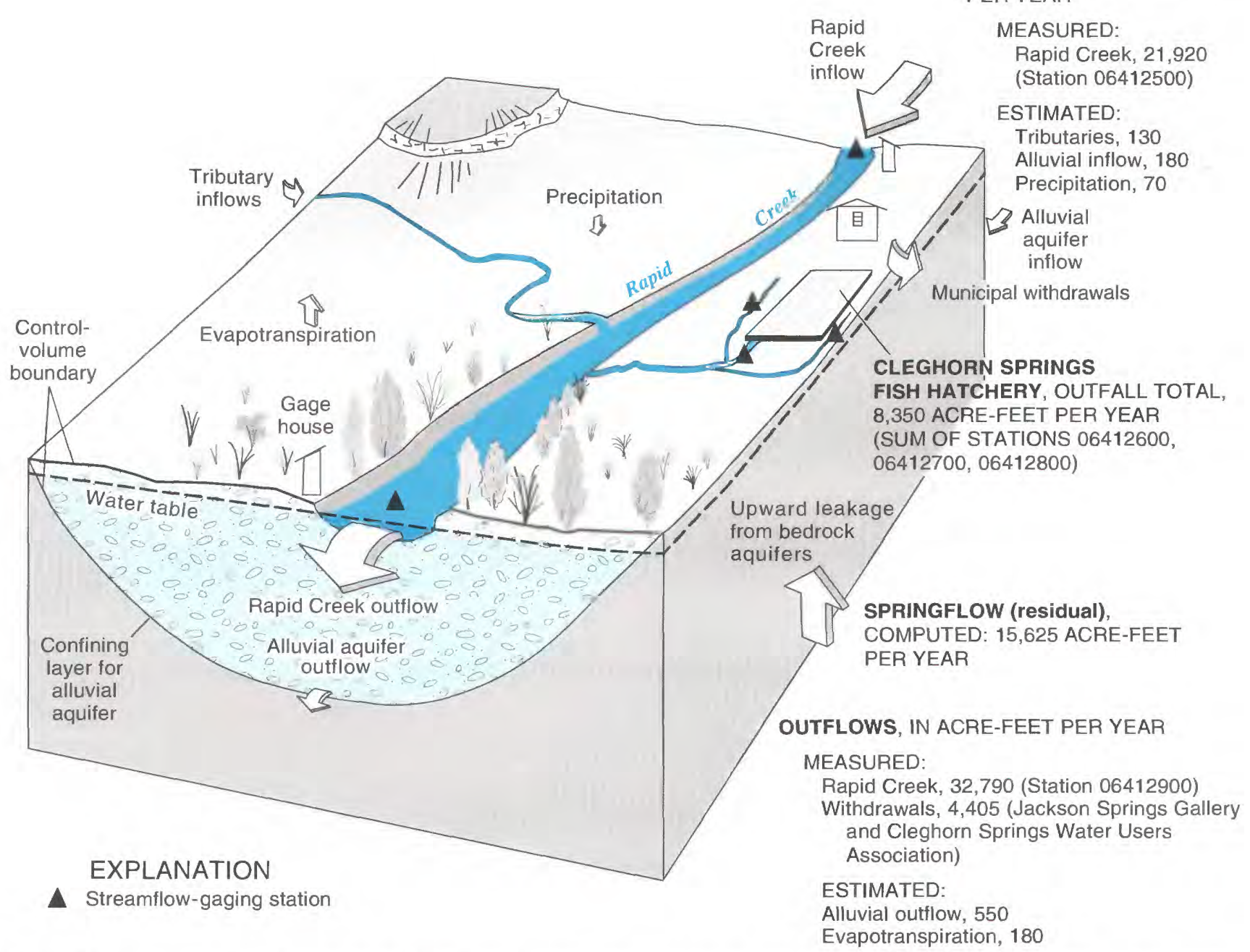

Figure 16. Control volume for Jackson-Cleghorn Complex showing mean annual inflows and outflows during water years 1988-89.

A profile of water levels (fig. 18) along the line of observation wells (fig. 14) indicates the hydraulic gradient in the alluvial aquifer slopes toward Rapid Creek when pumps are on. When pumps are off and a static equilibrium is established, the hydraulic gradient slopes in both directions away from well CS-1. This probably results from the upwelling of Jackson and Cleghorn Springs into the alluvium.

\section{Interactions with Rapid Creek}

Effects of pumping of Jackson Springs Gallery on streamflow in Rapid Creek and the outfall from
Cleghorn Springs are shown in figure 19 for October through December of WY 1988-90. The gaged gain across this reach of Rapid Creek is computed by subtracting the flow at the upstream gaging station (06412500) from the flow at the downstream gaging station (06412900). Rapid Creek, which routinely gains flow across this reach, gains additional flow during nonpumping periods. A substantial part of this additional flow was contributed by the outfall from the Cleghorn Springs Fish Hatchery (sum of three channels), which increased in flow during the nonpumping periods. 


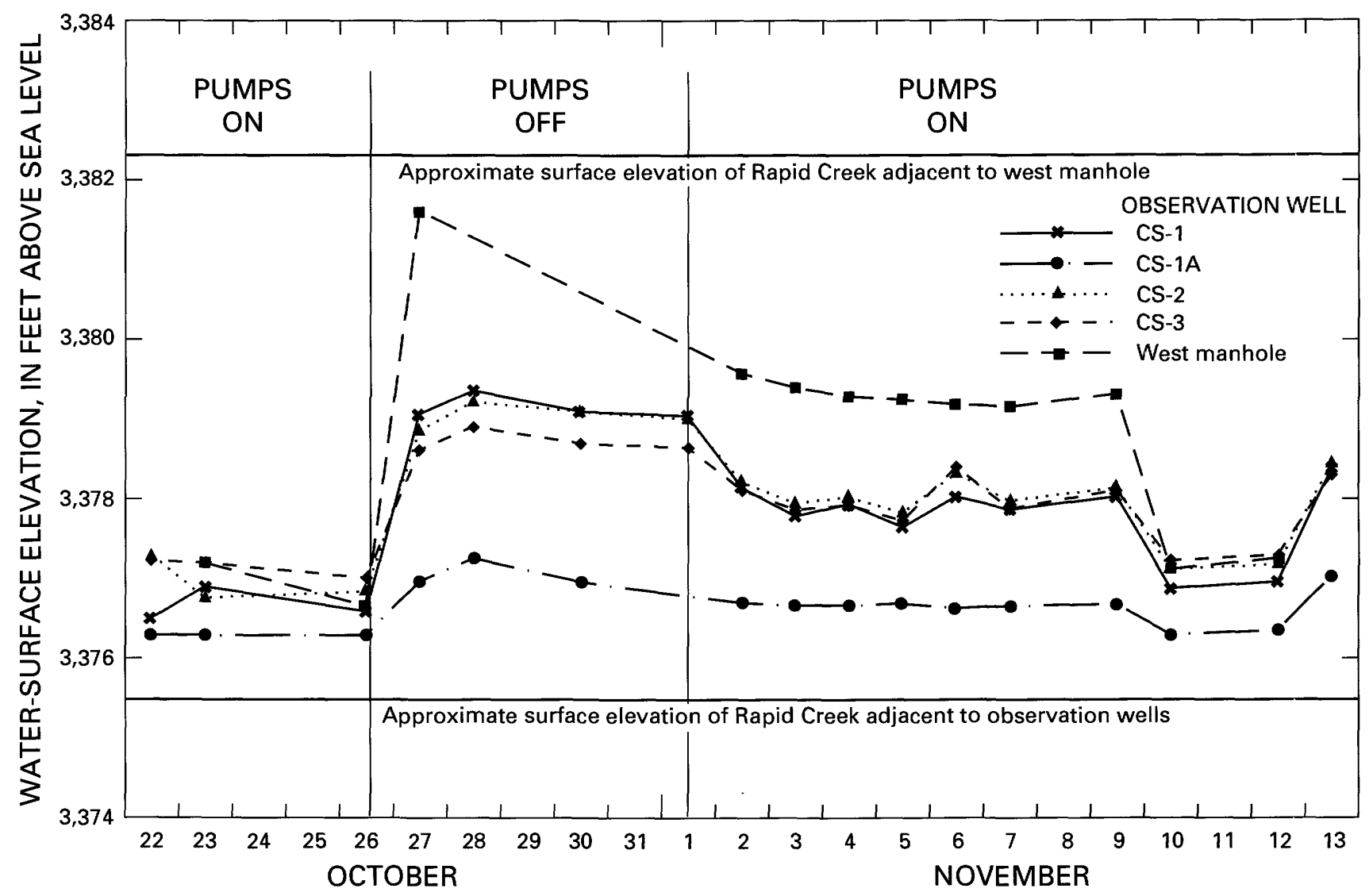

Figure 17. Measured water level of selected observation wells near Jackson Springs Gallery during gallery cycling, October 22 through November 13, 1987.

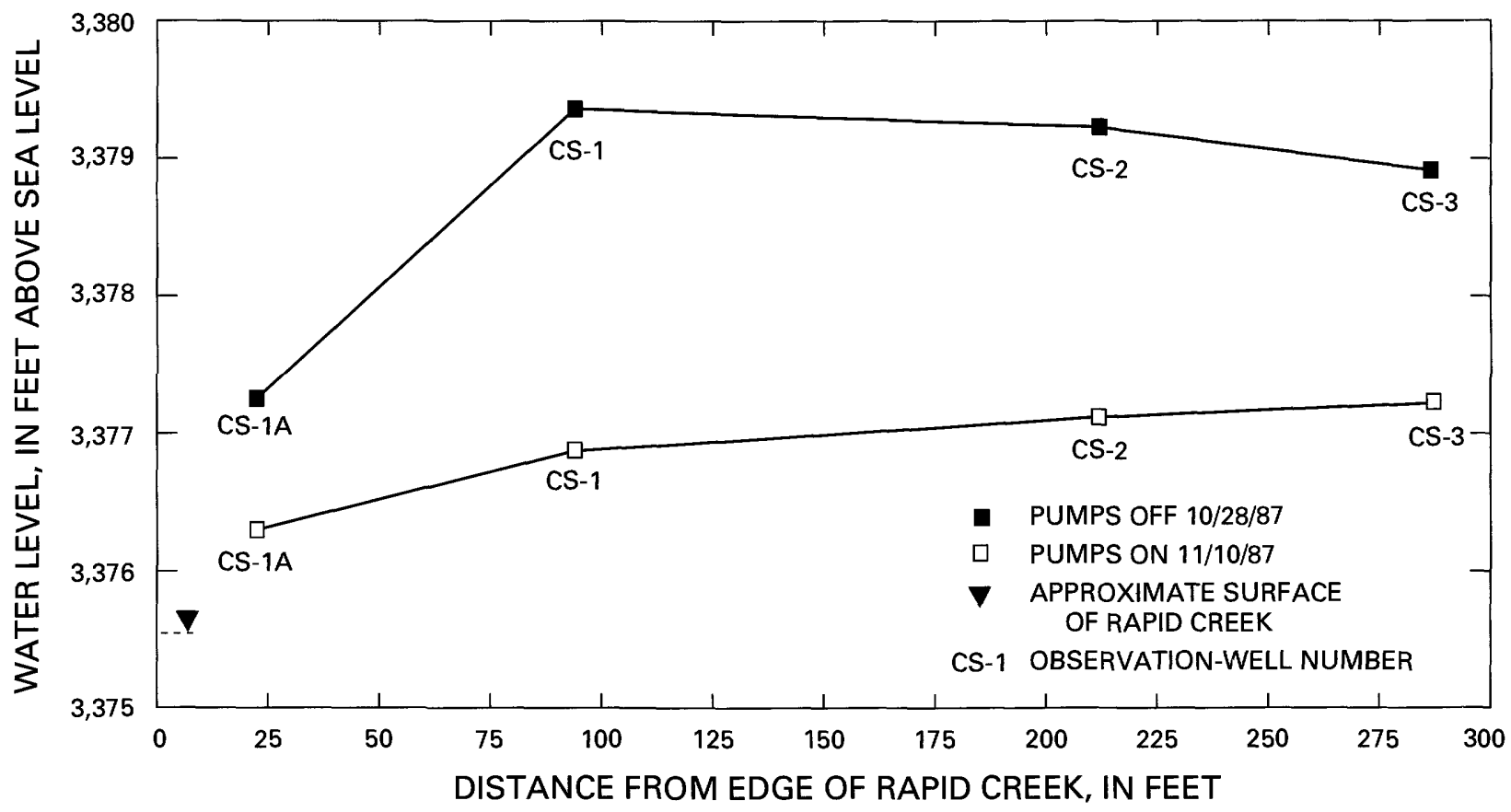

Figure 18. Cross-sectional profile of alluvial water level during gallery cycling at Jackson Springs Gallery. 


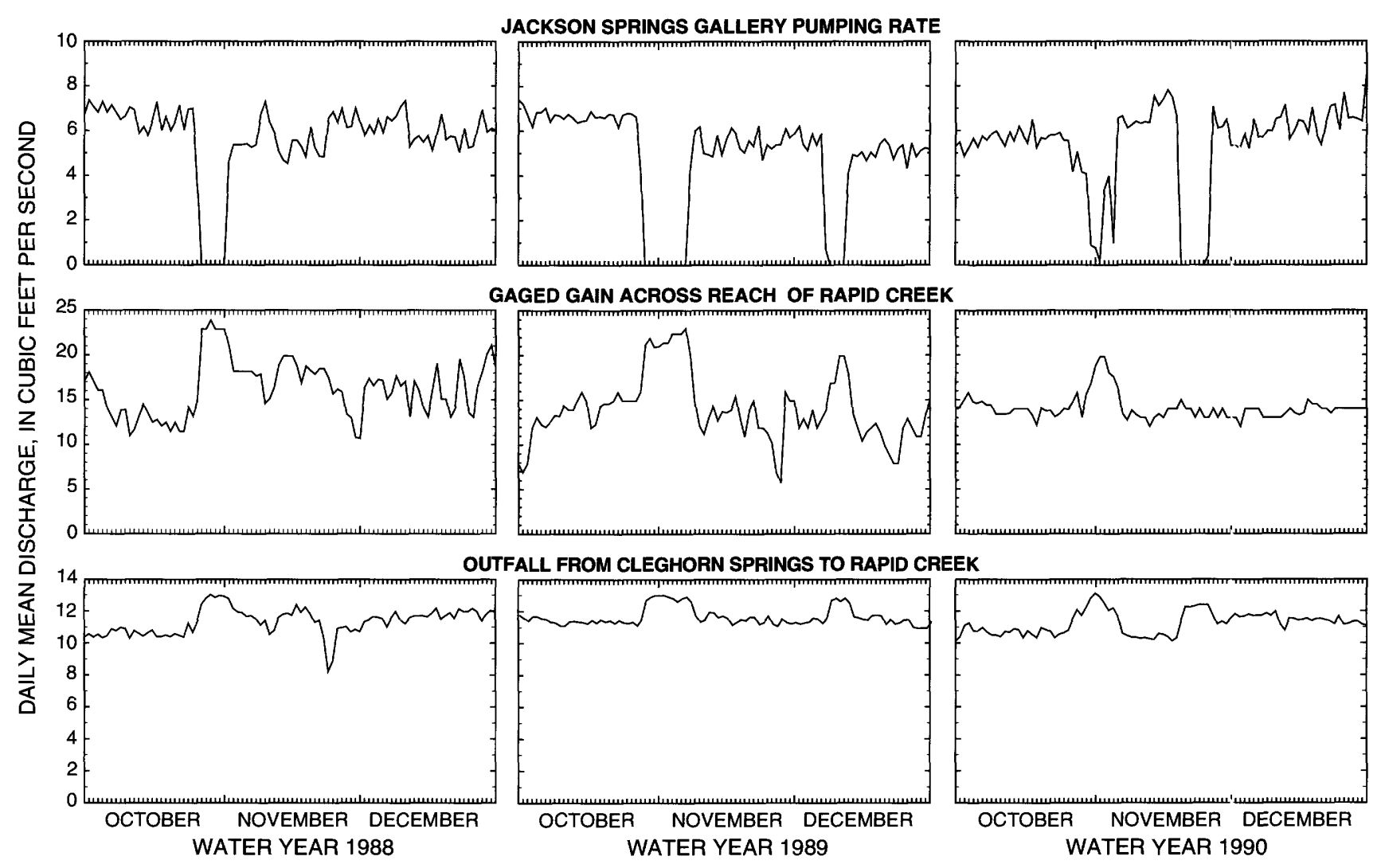

Figure 19. Comparison of Jackson Springs Gallery pumping rate, gaged gain across reach, and outfall from Cleghorn Springs, October through December, water years 1988-90.

The effects of gallery pumping on distribution of flow within the Jackson-Cleghorn Complex were analyzed for each of four scheduled cycling periods (fig. 11). Each cycle consisted of three periods (pumps on, pumps off, pumps on) of equal duration, separated by 1-day transition periods for equilibration of the alluvial aquifer. Daily streamflow and selected calculated values for the four cycling periods are presented in table 17 in the Supplemental Information section. Results of the analyses for three of the four cycling periods are presented in table 8. Results for the fourth cycling period (Nov. 13 through Dec. 2, 1989), which are suspect because of a large period of estimated record for station 06412500, Rapid Creek above Canyon Lake (table 17), are not included in table 8.

The average decrease in the pumping rate for the three cycling periods was $5.75 \mathrm{ft}^{3} / \mathrm{s}$ (table 8 ). As a result, the gaged gain of Rapid Creek increased by $7.25 \mathrm{ft}^{3} / \mathrm{s}$ (from an average of $13.87 \mathrm{ft}^{3} / \mathrm{s}$ with pumps on to $21.12 \mathrm{ft}^{3} / \mathrm{s}$ with pumps off). This increase consisted of increased outfall from Cleghorn Springs Fish Hatchery and increased seepage from the alluvium to
Rapid Creek. The outfall from the hatchery (measured at gaging stations 064 12600, 06412700, anc' 06412800; fig. 14) increased by an average of $1.42 \mathrm{ft}^{3} /:$ during the three cycling periods. Seepage from the alluvium to Rapid Creek (calculated as the gaged gain of Rapid Creek minus the outfall from Cleghorn Springs) increased by an average of $5.83 \mathrm{ft}^{3} / \mathrm{s}$. Increased seepage from the alluvium was visually apzarent during the nonpumping periods.

Total springflow, which is calculated as the sum of gallery production and the gaged gain of Rapid Creek, increased by an average of $1.50 \mathrm{ft}^{3} / \mathrm{s}$ during nonpumping periods (table 8). A physical exp ${ }^{1}$ anation for increased springflow is not apparent. In fact, a decrease in springflow might be anticipated because discontinuation of pumping increases the hydraulic haad within the alluvial aquifer (figs. 17 and 18), thus decreasing the hydraulic gradient from the underlying bedrock aquifer to Jackson-Cleghorn Springs. The small calculated increase in springflow may reflect the limitations of measurement accuracy rather than an act tal increase in springflow. 
Table 8. Comparison of mean daily flow values for selected pumping and nonpumping periods at the Jackson-Cleghcrn Complex

\begin{tabular}{|c|c|c|c|c|c|c|}
\hline \multirow[b]{2}{*}{$\begin{array}{c}\text { Period } \\
\text { (month/day) }\end{array}$} & \multirow[b]{2}{*}{ Test result } & \multicolumn{5}{|c|}{ Flow component, in cubic feet per second } \\
\hline & & $\begin{array}{c}\text { Jackson } \\
\text { Springs } \\
\text { Gallery } \\
\text { production } \\
\text { (1) }\end{array}$ & $\begin{array}{c}\text { Gaged gain } \\
\text { across reach } \\
\text { of Rapid Creek } \\
\text { (2) }\end{array}$ & $\begin{array}{l}\text { Outfall from } \\
\text { Cleghorn } \\
\text { Springs Fish } \\
\text { Hatchery } \\
\text { (3) }\end{array}$ & $\begin{array}{c}\text { Seepage }^{1} \\
(2-3)\end{array}$ & $\begin{array}{c}\text { Tota' } \\
\text { springfl }>w^{2} \\
(1+2)\end{array}$ \\
\hline \multicolumn{7}{|c|}{1987 test } \\
\hline \multirow[t]{3}{*}{$10 / 20-11 / 08$} & Mean (pumps on) & 5.97 & 15.16 & 11.25 & 3.91 & 21.13 \\
\hline & Mean (pumps off) & 0 & 22.97 & 12.85 & 10.12 & 22.97 \\
\hline & Difference of means & -5.97 & 7.81 & 1.60 & 6.21 & 1.84 \\
\hline \multicolumn{7}{|c|}{ First 1988 test } \\
\hline \multirow[t]{3}{*}{$10 / 18-11 / 18$} & Mean (pumps on) & 6.08 & 14.14 & 11.44 & 2.70 & 20.22 \\
\hline & Mean (pumps off) & 0 & 21.90 & 12.85 & 9.05 & 21.90 \\
\hline & Difference of means & -6.08 & 7.76 & 1.41 & 6.35 & 1.68 \\
\hline \multicolumn{7}{|c|}{ Second 1988 test } \\
\hline \multirow[t]{7}{*}{$12 / 04-12 / 17$} & Mean (pumps on) & 5.21 & 12.31 & 11.47 & .84 & 17.52 \\
\hline & Mean (pumps off) & 0 & 18.50 & 12.72 & 5.78 & 18.50 \\
\hline & Difference of means & -5.21 & 6.19 & 1.25 & 4.94 & .98 \\
\hline & \multicolumn{6}{|c|}{ Average for three periods } \\
\hline & Mean (pumps on) & 5.75 & 13.87 & 11.39 & 2.48 & 19.62 \\
\hline & Mean (pumps off) & 0 & 21.12 & 12.81 & 8.31 & 21.12 \\
\hline & Difference of means & -5.75 & 7.25 & 1.42 & 5.83 & 1.50 \\
\hline
\end{tabular}

\footnotetext{
${ }^{1}$ Seepage is the flow from the alluvium to the creek, calculated as the gaged gain of Rapid Creek minus the outfall from Cleghorn Springs Fish Hatchery.

${ }^{2}$ Total springflow of Jackson-Cleghorn Springs, calculated as the gaged gain of Rapid Creek plus production of Jackson Springs Gallery.
}

The outfall from the Cleghorn Springs Fish Hatchery also is affected by the rate of streamflow (or stage) within Rapid Creek, although this effect is less pronounced than the effect from pumping of the Jackson Springs Gallery. Larger releases from Pactola Reservoir during summer irrigation months (May through September) generally correspond to increased outfall from the hatchery (fig. 20). A multiple linearregression analysis was used to quantify relations among the hatchery outfall (dependent variable), streamflow measured at station 06412500 (Rapid Creek above Canyon Lake) and the gallery pumping rate. The pumping rate is included as an independent variable because of the demonstrated effect of gallery pumping on outfall from the hatchery. The resulting regression equation, using daily mean values in cubic feet per second, for WY 1988-90 is:

$$
Q_{C S O}=0.014 Q_{R C}-0.25 Q_{J S G}+12.5
$$

where

$$
\begin{aligned}
Q_{C S O}= & \text { outfall from Cleghorn Springs; } \\
Q_{R C}= & \text { flow of Rapid Creek, measured at gaging sta- } \\
& \text { tion } 06412500 \text { (Rapid Creek above C } 2 \text { nyon } \\
& \text { Lake); and } \\
Q_{J S G}= & \text { Jackson Springs Gallery pumping rate. }
\end{aligned}
$$

The coefficient of determination $\left(\mathrm{R}^{2}\right)$ for this relation indicates that only 34 percent of the dail' variability of the outfall from Cleghorn Springs can be predicted by the independent variables. The F ratio (279) and the p-value associated with the slope $(<0.001)$, however, indicate a high probability that the slope is significantly non-zero. Although considerable error exists for predicting individual daily values. the regression equation is useful for estimating averages 


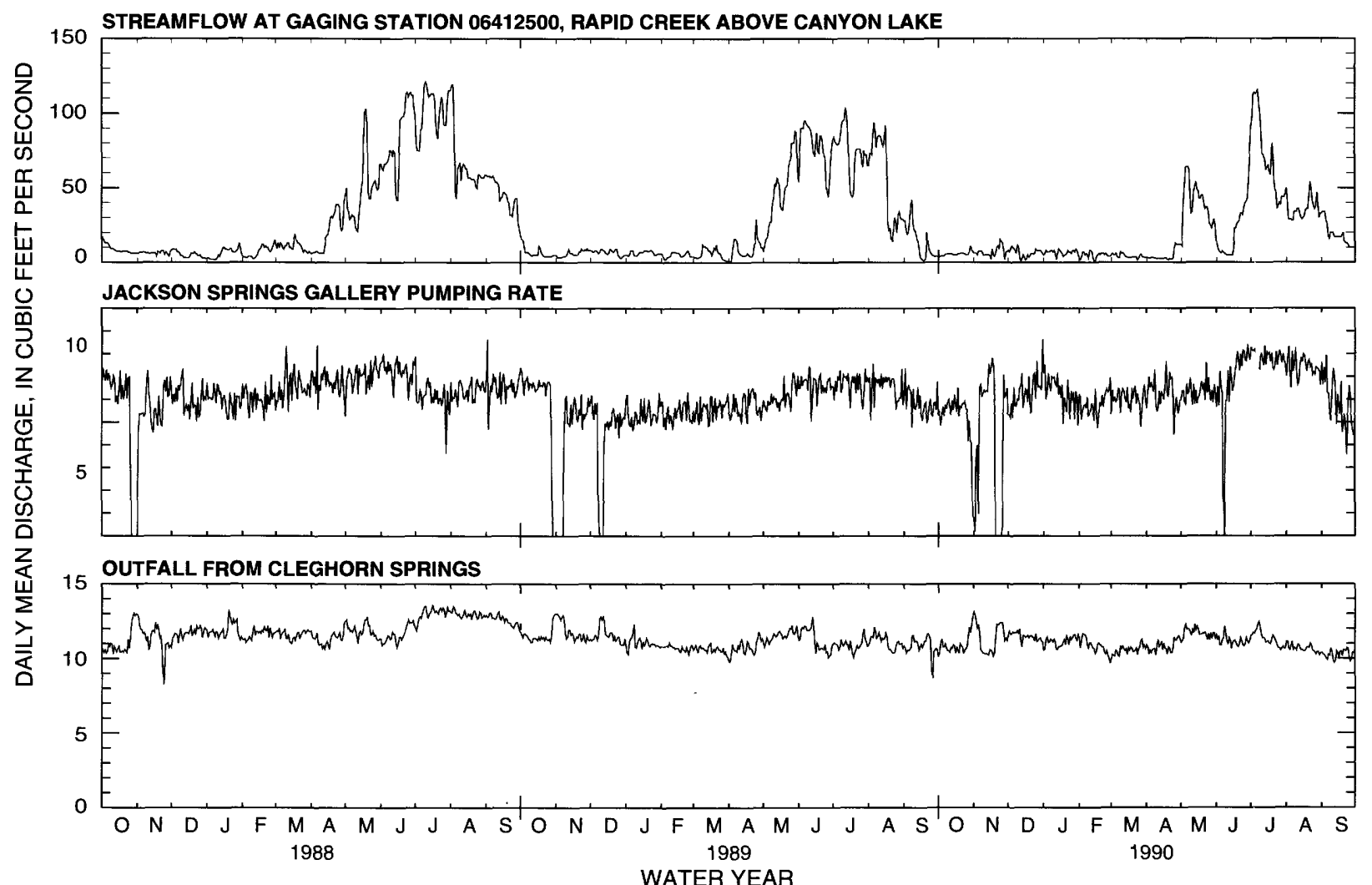

Figure 20. Comparison of Rapid Creek streamflow, Jackson Springs Gallery pumping rate, and outfall from Cleghorn Springs, water years 1988-90.

for longer periods. This relation may be important for (1) future evaluation of potential effects on springflow from large-scale development of water supplies from bedrock sources, (2) development of relations between springflow and bedrock potentiometric head, or (3) development of relations between springflow and long-term climatic conditions (recharge).

\section{Hydrochemical Interpretations}

Hydrochemical information was used to examine possible sources of water at the JacksonCleghorn Complex. Dissolved oxygen and nitrogen (table 18 in the Supplemental Information section) were measured at the infiltration galleries and at selected sites for comparison (table 6 and fig. 12). The saturation of dissolved gases in water from the Jackson Springs manhole was compared to other possible sources of water in the area (fig. 21). Most ground water from bedrock sources in the Rapid Creek study area was undersaturated with respect to oxygen and supersaturated with respect to nitrogen. Water in Rapid Creek at Jackson Springs generally was near or slightly above saturation with respect to dissolved oxygen and nitrogen and showed more variability than water from the ground-water sites. The maximum measured saturation value for nitrogen during the study was about 128 percent for the Chapel Lane well, which produces from the Madison aquifer, and the minimum value was about 94 percent for the Rapid Creek at Jackson Springs pumphouse site (table 18).

Nitrogen gas is used to differentiate ground water from surface water because it behaves as a conservative tracer (Heaton and Vogel, 1981). Denitrification was considered as a nitrogen-forming reaction that could produce supersaturation but was rejected for several reasons. First, denitrification occurs under anaerobic conditions, but all ground-water samples collected were oxygenated. Second, the reaction times, at typical temperatures, for denitrification to occur are much longer than the traveltimes along the flowpaths between the creek and galleries. Third, isotopic analysis of dissolved nitrogen in water from Cleghorn Springs indicated the gases were of atmosfheric origin (C. Kendall, U.S. Geological Survey, written commun., 1987). Furthermore, entrainment of air at the time of recharge and subsequent changes in temperature and pressure commonly are accepted as processes by which nitrogen supersaturates within ground water (Heaton and Vogel, 1981). 


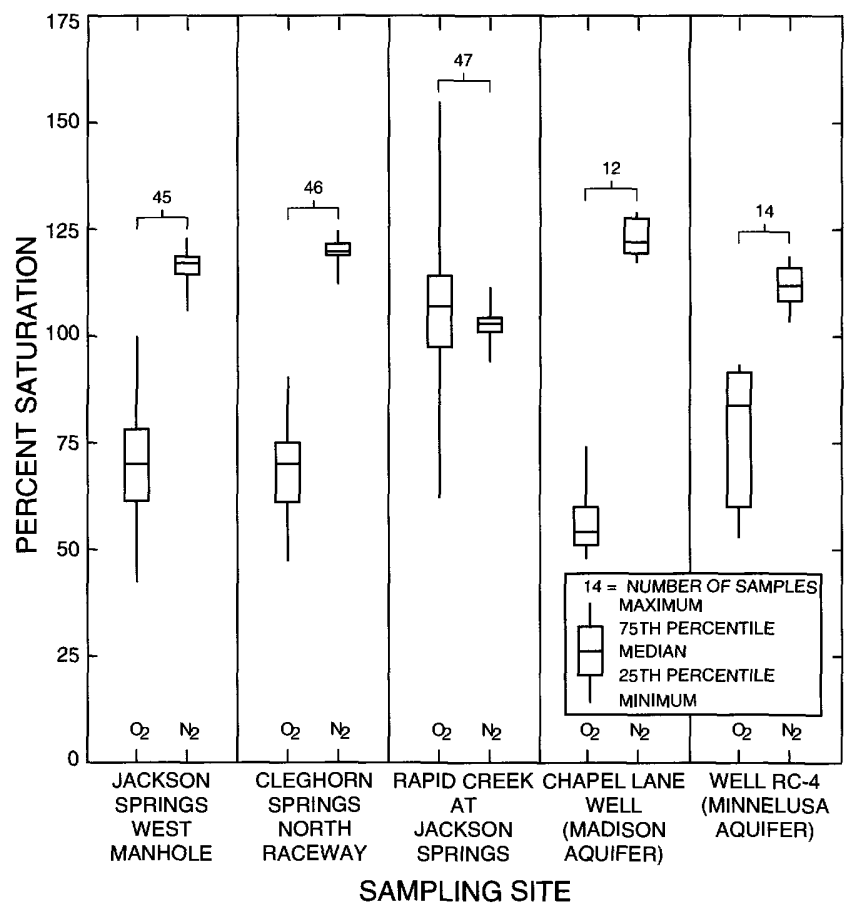

Figure 21. Percent saturation of dissolved oxygen and nitrogen for Jackson-Cleghorn Complex and other selected sites.
The dissolved gas data indicate that water from the Jackson Springs Gallery and water from Cleçhorn Springs are similar (fig. 21). The relative saturation of dissolved nitrogen for Jackson Springs is slightly lower than for Cleghorn Springs, which could be explained by a minor amount of induced infiltration from $R$ apid Creek.

The isotopes of radium ( $\mathrm{Ra}-226$ and $\mathrm{Ra}-22^{\circ}$ ) provide additional evidence on potential sources of water at the Jackson-Cleghorn Complex. Activit: levels and activity ratios of radium isotopes for sites in the study area are presented in table 19 in the Supplemental Information section. Water from the Jackson Springs Gallery falls on a mixing line between Rapid Creek and Cleghorn Springs, which are the two most probable sources (fig. 22). A mixing line commonly is used in isotopic studies to relate waters of different isotopic composition. If the isotopic composition of a water lies between the isotopic composition of two other waters, a mixture of the two end members is indicated.

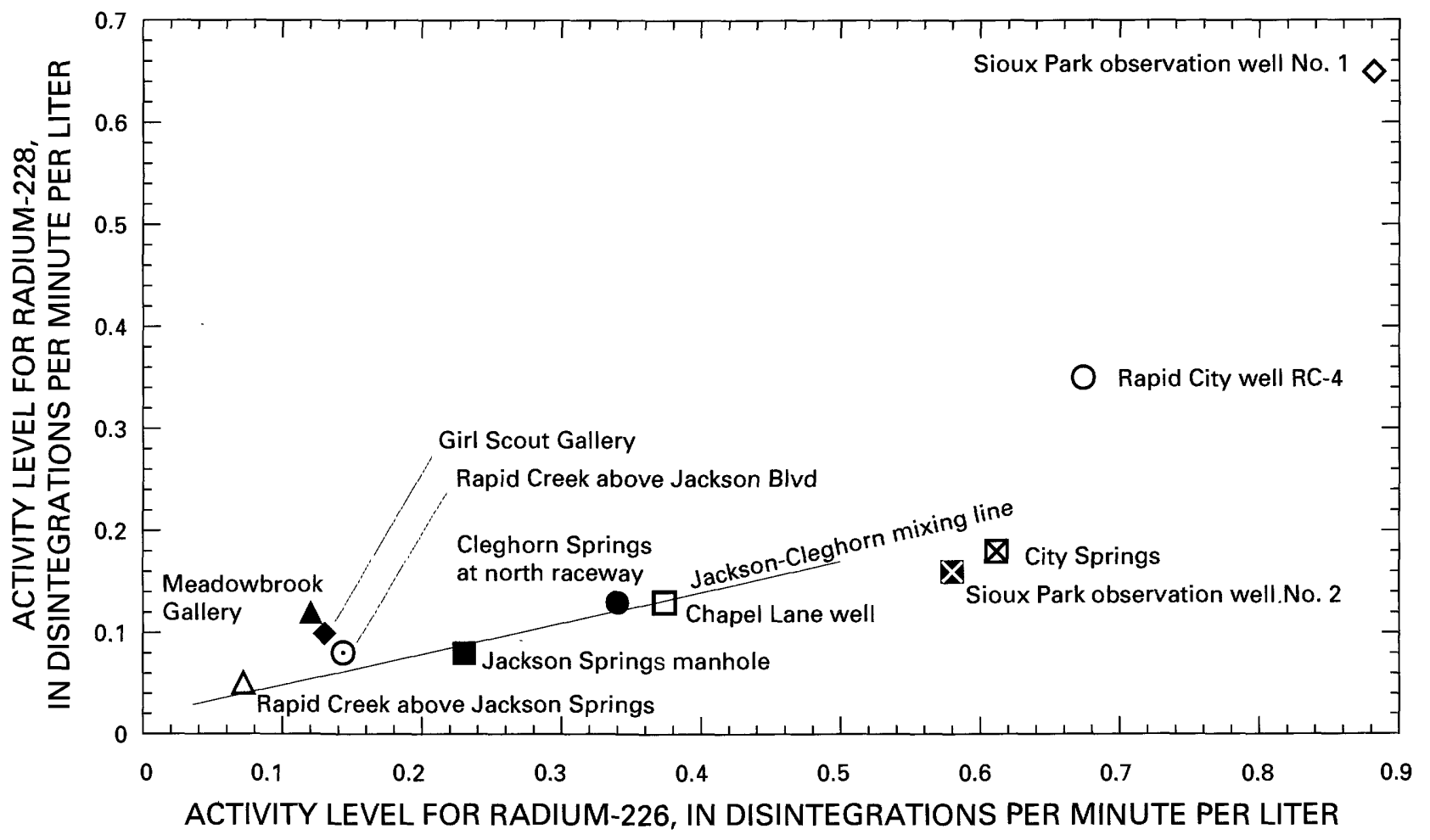

Figure 22. Relation between radium-228 and radium-226 isotopes for selected sites, with probable mixing line for Jackson and Cleghorn Springs. 
The stable isotopes of oxygen and hydrogen provide additional evidence on potential sources of water at the Jackson-Cleghorn Complex. Analyses of samples from selected sites in the study area are presented in table 19 in the Supplemental Information section. An understanding of the isotopic composition of Rapid Creek is helpful for subsequent comparisons to ground water. As shown in figure 23, the isotopic composition of Rapid Creek becomes progressively heavier as the creek descends in elevation from the headwaters (Rhoads Fork) and flows eastward to Rapid City (Rapid Creek at Rapid City). Evaporation processes usually do not substantially alter the isotopic composition of streams or rivers unless large reservoirs affect the flow (Gat and Gonfiantini, 1981). Pactola and Deerfield Reservoirs apparently are sufficiently large, relative to inflows, to alter the isotopic composition of Rapid Creek.

The isotopic composition of Rapid Creek immediately below Pactola Dam and above (and at) the Jackson Springs pumphouse shows little seasonal variation (fig. 23). Pactola Reservoir homogenizes the isotopic composition of Rapid Creek, with little subsequent alteration in the reach immediately downstream. The isotopic composition of Cleghorn Springs (at north raceway) is consistently heavier than that of Rapid Creek, causing variations in downstream composition in response to seasonal chances in releases from Pactola Reservoir. The proportion of flow added to Rapid Creek by Jackson and Cleghorn Springs ranges from less than 10 percent curing large releases to more than 50 percent during small releases (fig. 20). Thus, in downstream reaches, th : isotopic composition of Rapid Creek is similar to that of Cleghorn Springs during winter months when releases are minimal and becomes progressively lighter as releases are increased.

Jackson and Cleghorn Springs were considered by Rahn and Gries (1973) to be of similar origin, discharging from the Madison aquifer. Back and others (1983) concluded that Cleghorn Springs probably is Madison aquifer water that has been influenced by minor dissolution of evaporites from the Minnelusa Formation. Values for $\delta^{18} \mathrm{O}$ and $\delta \mathrm{D}$ for Ravid Creek, Jackson Springs, Cleghorn Springs, City Springs, and nine wells that produce from the Madison aquifer are shown in figure 24. The Madison aquifer water has two apparent groupings - one of heavier water for sites south of Rapid Creek (table 6 and fig. 12) and the other of lighter water for sites north of Rapid Creek. The isotopically light water in the Madison aquifer to the north is similar to that of Rapid Creek, incicating a possible flowpath to the north for water re-harged in the loss zone of Rapid Creek in Dark Canyon.

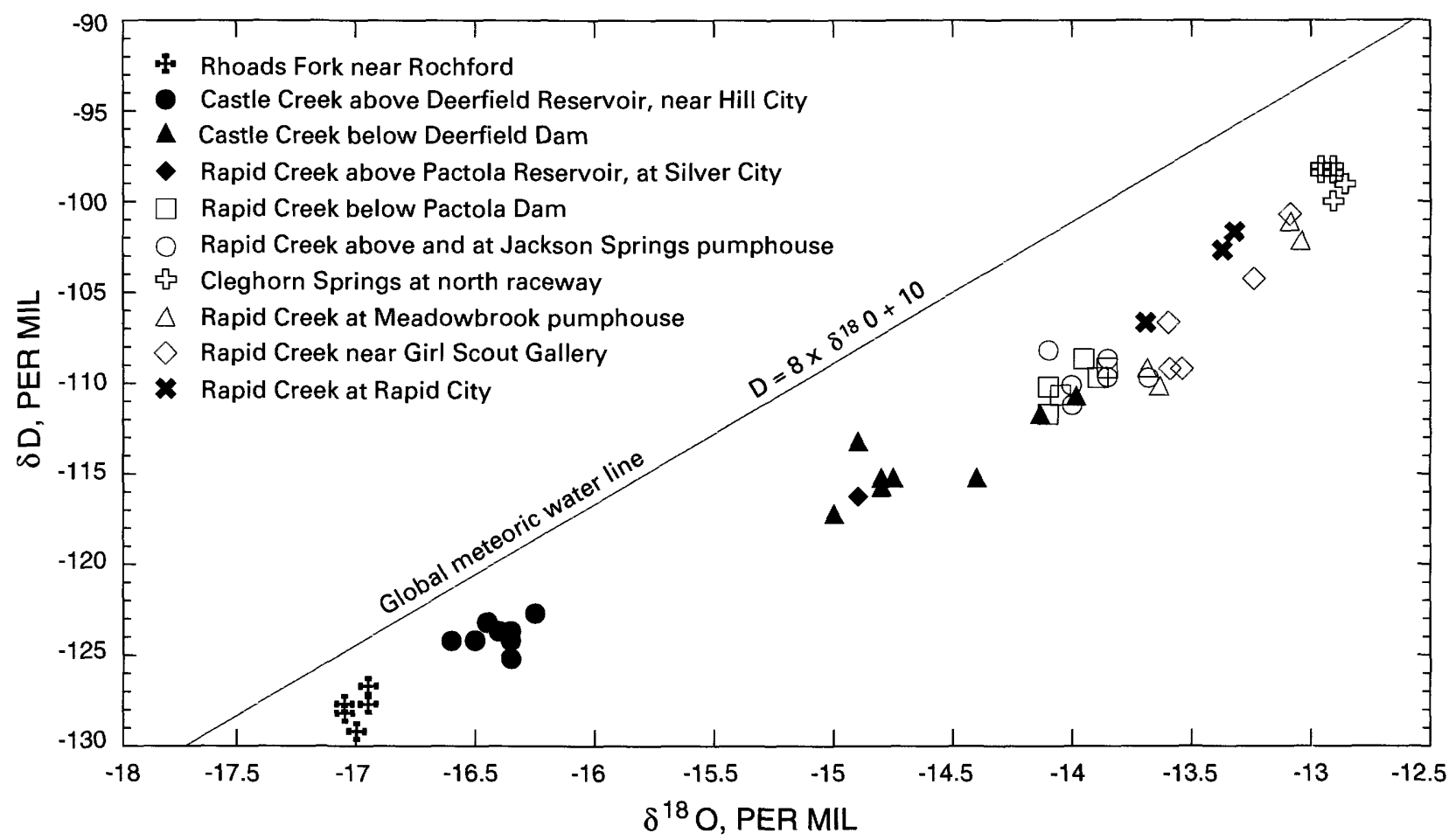

Figure 23. Relation between $\delta \mathrm{D}$ and $\delta^{18} \mathrm{O}$ illustrating the evolution of Rapid Creek water, with comparison to global meteoric water line (Craig, 1961). 


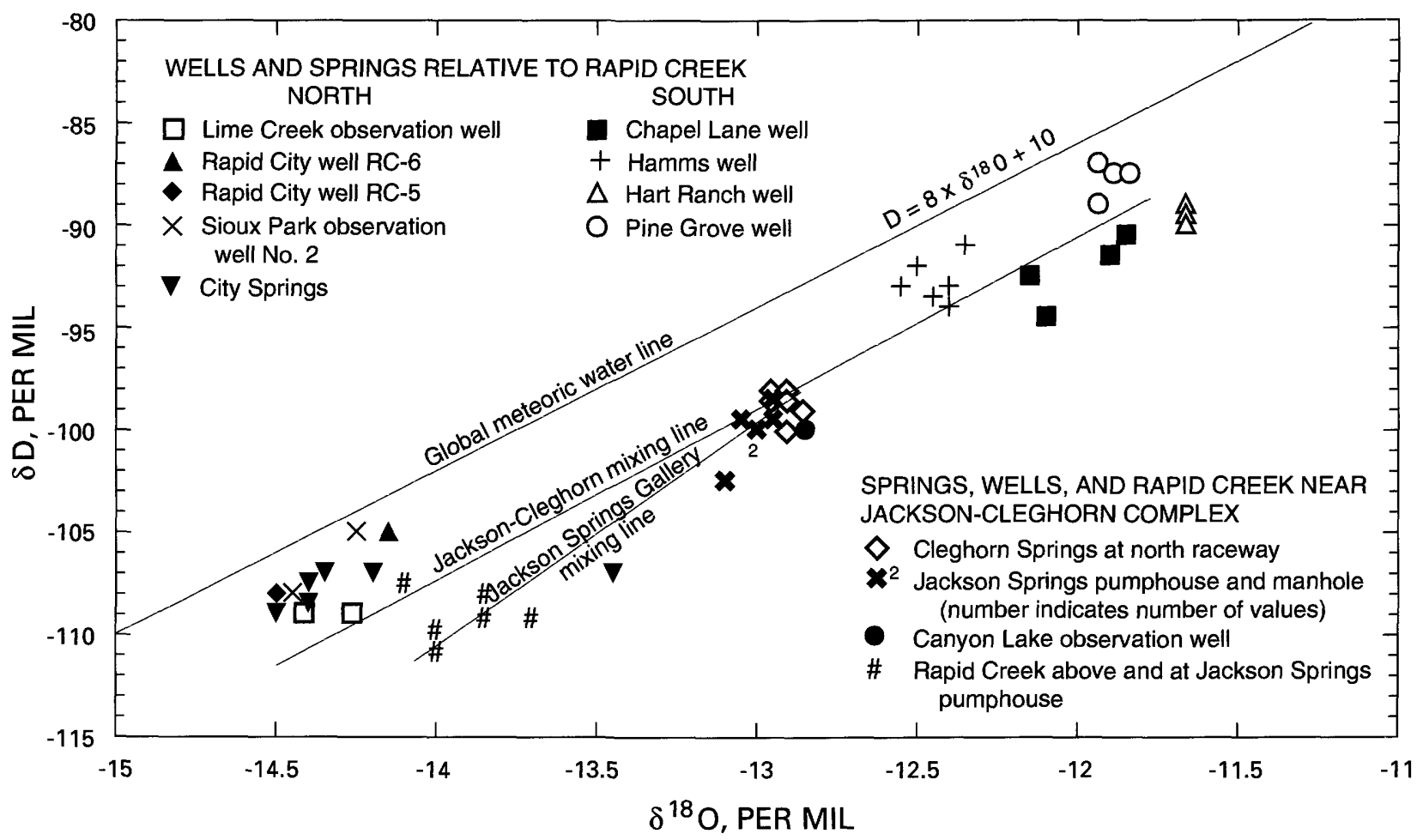

Figure 24. Relation between $\delta D$ and $\delta{ }^{18} \mathrm{O}$ for Rapid Creek and selected springs and Madison wells in study area. The groupings show lighter water in the Madison aquifer to the north of Rapid Creek and heavier water to the south.

Jackson Springs, Cleghorn Springs, and the Canyon Lake observation well (Madison aquifer) fall along the "Jackson-Cleghorn" mixing line (fig. 24) that includes heavier water (from the south) as one end member and lighter water (from the north and/or from Rapid Creek) as the other end member. The mix indicates a slightly larger component of heavier water from the south, but the relative proportion contributed from the north or from Rapid Creek cannot be determined. The component of heavier water from the south indicates that Jackson and Cleghorn Springs are not simply "resurgent" springs in which streamflow lost in Dark Canyon reappears at the springs. Isotopically heavier water, similar to that from the south, apparently is present in the mix; however, the amount of streamflow contributed by Rapid Creek cannot be determined from this analysis.

The conclusion that Jackson and Cleghorn Springs represent a regional discharge point from the Madison aquifer and have a large contributing area is consistent with the large, steady discharge from these springs. This hydrochemical interpretation is consistent with potentiometric maps for the Madison aquifer presented by Peter (1985) and Greene (1993); however, flow lines are not necessarily strictly orthogonal to equipotential lines for anisotropic aquifers (Greere, 1997). Peter and others (1991) reported that solution cavities within the Madison Limestone are preferentially oriented along certain axes, and Greene (19.33) reported strongly anisotropic transmissivity in western Rapid City.

Water produced at the Jackson Springs Gallery consists predominantly of bedrock springflow and is similar in composition to water from Cleghorn Springs (fig. 24). Water from the gallery consistently is slightly lighter than that from Cleghorn Springs, however, and falls directly on the "Jackson Gallery" mixing line with a minor component of induced infiltration from Rapid Creek. Based on the stable isotopes, it is estimated that about 90 percent of the gallery production is sprirgflow from the Madison aquifer and about 10 percent is induced infiltration from Rapid Creek. This propotion probably varies with the pumping rate, however. This finding is similar to that based on the dissolved gases and radium isotopes and also is consistent with allıvial water-level data, which indicate a large spring source and only minor drawdown from gallery pumping. 


\section{Summary for Jackson Springs Gallery}

The Jackson Springs Gallery was constructed in 1942 over the site of a large carbonate spring of the same name. Gallery production during WY 1988-89 averaged 4,355 acre-ft/yr (equivalent to $6.0 \mathrm{ft}^{3} / \mathrm{s}$ ), and the measured outfall from the adjacent Cleghorn Springs Fish Hatchery was 8,350 acre-ft/yr $\left(11.5 \mathrm{ft}^{3} / \mathrm{s}\right)$. The control-volume analysis indicates that combined bedrock springflow from Jackson and Cleghorn Springs averaged about 15,600 acre- $\mathrm{ft} / \mathrm{yr}\left(21.6 \mathrm{ft}^{3} / \mathrm{s}\right)$. The standard error $( \pm 1,200 \mathrm{acre}-\mathrm{ft} / \mathrm{yr})$ is small, indicating that the uncertainty associated with the estimate is small.

Gallery pumping caused drawdown of about $5 \mathrm{ft}$ below the creek level in the west manhole of the gallery, indicating that at least part of the gallery production results from induced infiltration from the creek. Drawdown was only about $2 \mathrm{ft}$ in observation wells located about $200 \mathrm{ft}$ east of the gallery, and the hydraulic gradient remained toward Rapid Creek. Water levels in the alluvial aquifer recovered completely within 2 days after pumping was discontinued, and flow in Rapid Creek responded almost immediately, with an increase similar to the pumping rate. Most of the increase consisted of additional seepage from the alluvium to the creek; however, the outfall from the hatchery also increased measurably. Flow of the hatchery outfall was determined to be related to flow (or stage) in Rapid Creek as well as to the gallery pumping rate.

The hydrochemical characteristics of Jackson and Cleghorn Springs are very similar. Water from both springs is supersaturated with respect to dissolved nitrogen and undersaturated with respect to dissolved oxygen, which is characteristic of bedrock aquifers in the area. It is concluded from interpretation of data for ${ }^{18} \mathrm{O}$ and $\mathrm{D}$ that Jackson and Cleghorn Springs represent a regional discharge point from the Madison aquifer. The flow of these springs consists of isotopically heavier water from the Madison aquifer south of Rapid Creek and a slightly smaller component of isotopically lighter water, which consists of a mix (of unknown proportions) of water from the north and water recharged in the loss zone of Rapid Creek in Dark Canyon. It is estimated that about 90 percent of the Jackson Springs Gallery production is springflow from the Madison aquifer and about 10 percent is induced infiltration from Rapid Creek.

\section{Meadowbrook Gallery}

The Meadowbrook Gallery (fig. 25) is located about $0.7 \mathrm{mi}$ downstream from Canyon Lake. The site was selected and developed during 1950-52 for an infiltration gallery because springs and a marsh existed in the area before development. The State of South Dakota approved the site for municipal water production with the condition that at least 40 acres around the gallery remain undeveloped. This condition gave rise to the Meadowbrook Golf Course. The Meadowbrook Gallery extends about $1,700 \mathrm{ft}$ from Rapid Creek (fig. 25), the greatest distance of the three galleries. The average depth of the gallery is about $20 \mathrm{ft}$ below land surface.

\section{Control-Volume Analysis}

The Meadowbrook control volume is defined as Rapid Creek and its alluvial aquifer from where streamflow is diverted at gaging station 06413300 , Leedy Ditch at headgate, to station 06413570, Rapid Creek above Jackson Boulevard (fig. 13). The surface area of the alluvial aquifer in this reach is about 240 acres. The width, hydraulic gradient, and transmissivity of the alluvial aquifer are about $0.33 \mathrm{mi}$, $0.011 \mathrm{ft} / \mathrm{ft}$, and $15,000 \mathrm{ft}^{2} / \mathrm{d}$ at the upstream extent and $0.67 \mathrm{mi}, 0.0054 \mathrm{ft} / \mathrm{ft}$, and $10,000 \mathrm{ft}^{2} / \mathrm{d}$, respectively, at the downstream extent of the reach (Geibel, 1991). The downstream decrease in transmissivity is caused by diminishing particle sizes within the alluvial aquifer.

Thickness and saturated thickness of the alluvial aquifer were determined for seismic-refraction profile D-D' (fig. 26) near the Meadowbrook Gallery (fig. 25). The thickness of alluvial deposits overlying the Spearfish Formation varies from near zero near Leedy Ditch to about $30 \mathrm{ft}$. The saturated thickress ranges from zero to about $25 \mathrm{ft}$. The seismic-ref action analysis and water-level measurements in observation wells near the gallery (table 14) indicate the depth to the water table is about 5 to $10 \mathrm{ft}$ when the gallery pumps are off.

Springflow entering the Meadowbrook control volume was computed to be about 700 acre- $\mathrm{ft} / \mathrm{yr}$ (equivalent to about $1.0 \mathrm{ft}^{3} / \mathrm{s}$ ) for WY $1988-89$ (fig. 27). Equation 2 was modified for this reach to include ditch inflow $\left(D_{i}\right)$ and ditch outflow $\left(D_{o}\right)$, resulting in:

$$
S F_{i} \pm e=R C_{o}+D_{o}+W_{s a}+E T_{s a}+A_{o}-R C_{i}-D_{i}-T_{i}-P_{s a}-A_{l}
$$




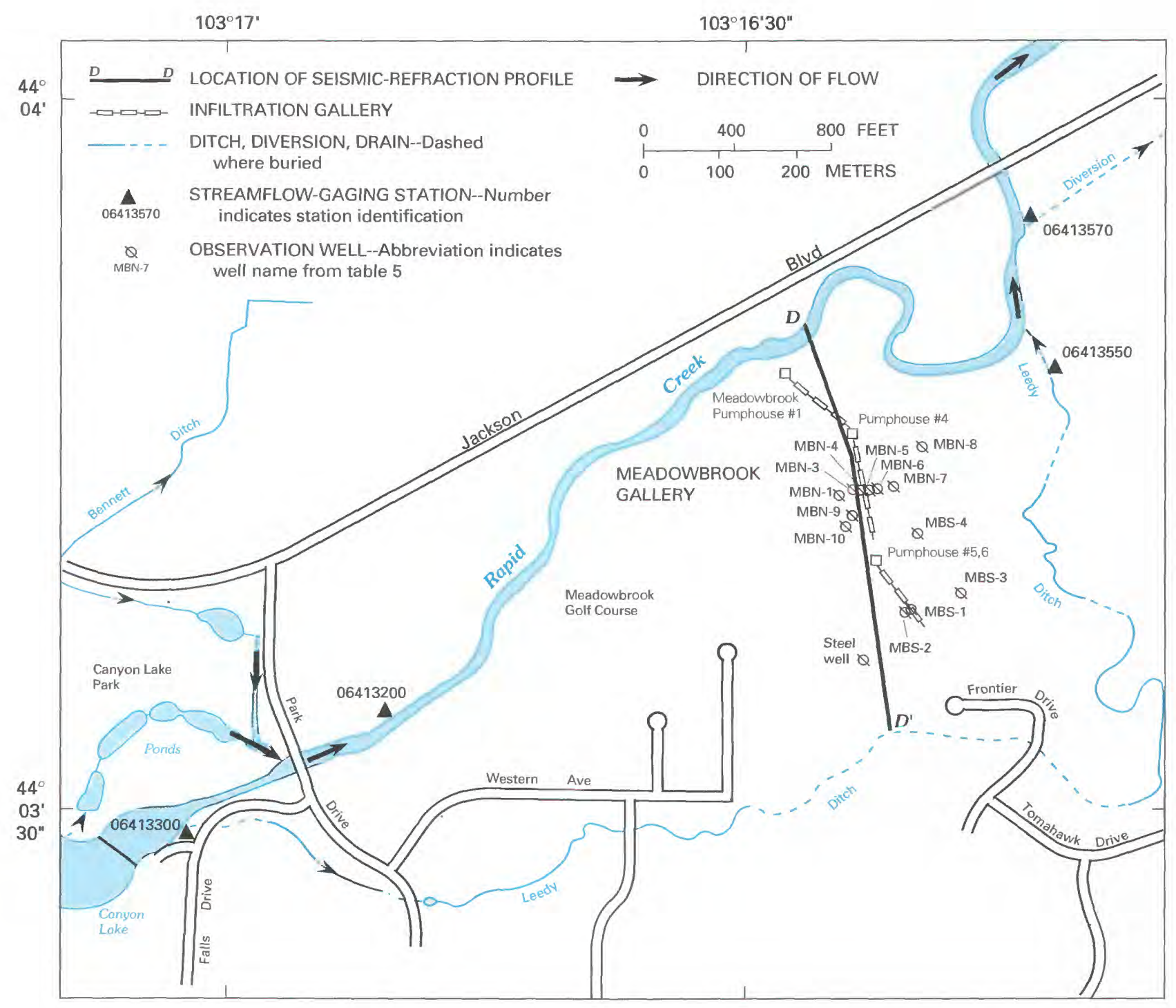

Figure 25. Meadowbrook Gallery site.

Values for most of the variables were obtained as previously described. Measured withdrawals of 168 acre-ft/yr for irrigation of Meadowbrook Golf Course (table 3 ) were neglected because irrigation occurs within the control volume. Withdrawals from Leedy Ditch were estimated as 244 acre-ft/yr based on the assumption that one-half of the average decrease in flow along the ditch resulted from withdrawals from the control volume. Springflow was computed by substituting the following values, which are shown with associated error terms, into equation 8 :
$R C_{i}=30,270( \pm 3$ percent $)$, measured at station 06413200 ;

$D_{i}=772( \pm 3$ percent $)$, measured at station 06413300 , plus 200 ( \pm 50 percent), estimated for Bennett Ditch;

$T_{i}=130$ ( \pm 50 percent $)$, estimated;

$P_{\text {sa }}=240$ ( \pm 25 percent $)$, estimated;

$A_{i}=2,300$ ( \pm 50 percent $)$, estimated;

$R C_{o}=29,375$ ( \pm 3 percent $)$, measured at station 06413570 ;

$D_{o}=100$ ( \pm 50 percent $)$, estimated for Bennett Ditch, plus 100 ( \pm 50 percent), estimated for a diversion to Jackson Pond; 
$W_{s a}=2,099$ ( \pm 3 percent $)$, measured for Meadowbrook Gallery, plus 207 ( \pm 3 percent), measured for irrigation of Arrowhead Golf Course, plus 244 ( \pm 50 percent), estimated for Leedy Ditch;

$E T_{s a}=870( \pm 25$ percent $)$, estimated; and

$A_{o}=1,600$ ( \pm 50 percent $)$, estimated.

Thus, springflow $\left(S F_{i}\right)=683$ or 700 acre-ft/yr (rounded).

The standard error of the residual was computed using equation 6. Thus, $S E_{S P R I N G}= \pm 1,900 \mathrm{acre}-\mathrm{ft} / \mathrm{yr}$, which is large relative to computed springflow into the reach. This indicates that the uncertainty associated with the estimate is large.

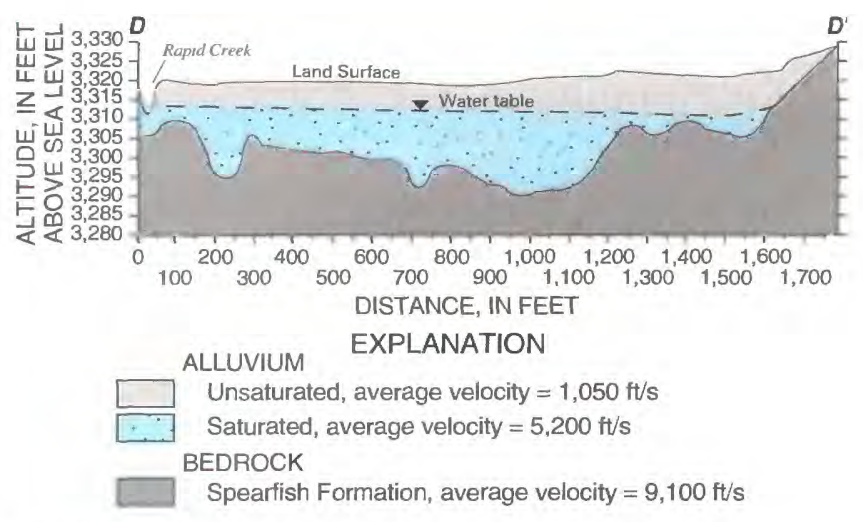

Figure 26. Geologic section from interpretation of Meadowbrook seismic-refraction profile (location of section shown in figure 25).

INFLOWS, IN ACRE-FEET PER YEAR

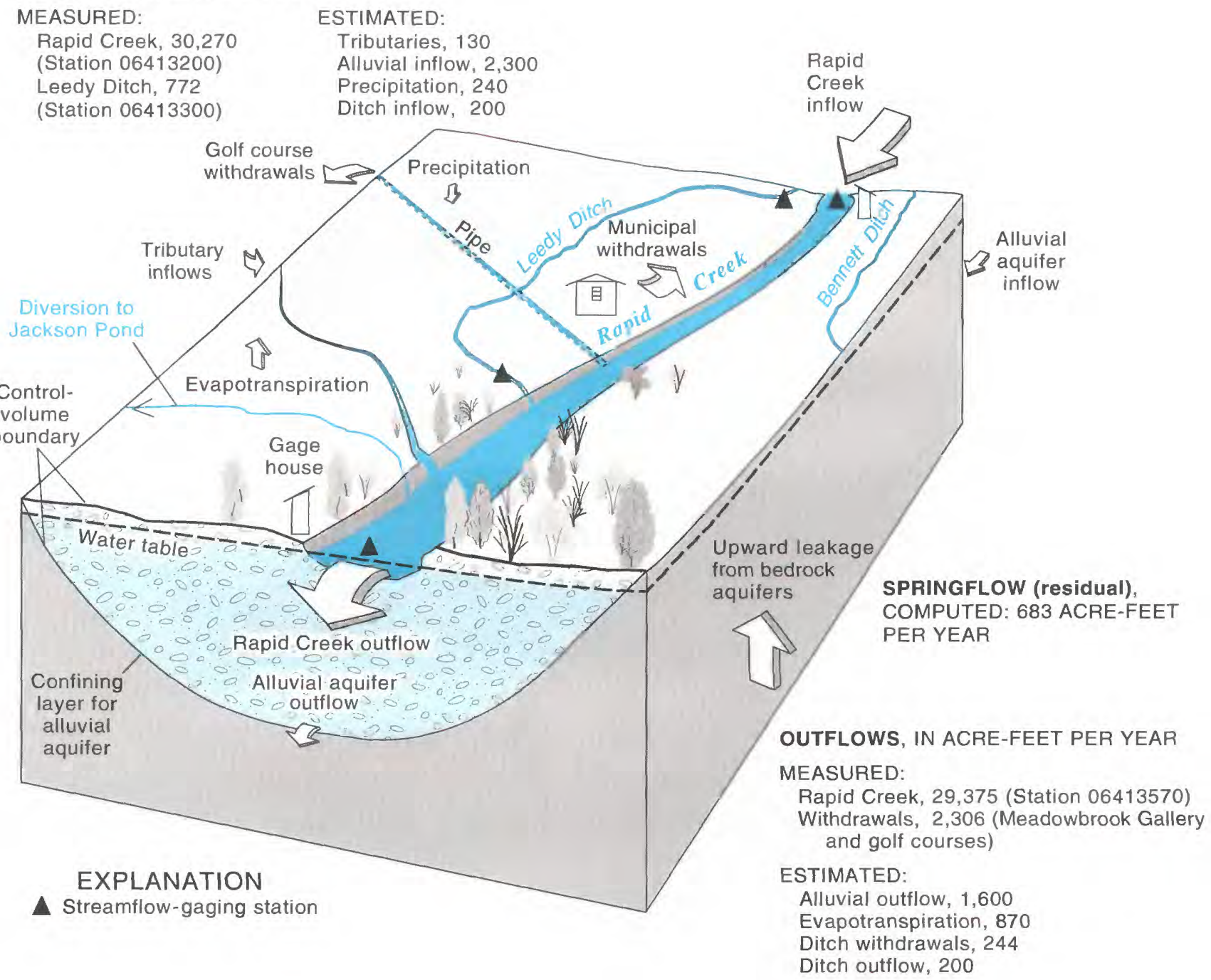

Figure 27. Control volume for Meadowbrook Gallery showing mean annual inflows and outflows during water years 1988-89. 


\section{Interactions with Alluvial Aquifer}

Observation wells near the Meadowbrook Gallery (fig. 25) provided information on effects of gallery pumping on water levels in the alluvial aquifer. The range in measured water levels in these observation wells, relative to a profile of Rapid Creek at a flow of about $70 \mathrm{ft}^{3} / \mathrm{s}$, is shown in figure 28 . The stage of Rapid Creek generally fluctuates by about $0.5 \mathrm{ft}$ as flow fluctuates within a typical range of about 20 to $150 \mathrm{ft}^{3} / \mathrm{s}$. The highest water levels in the observation wells occurred during nonpumping periods. The lowest levels, which occurred during periods of maximum pumping, indicate that the gallery may be able to induce flow from the creek to the alluvium for a considerable distance downstream.

A longitudinal profile of alluvial water levels is shown in figure 29. During nonpumping periods, the ground-water gradient is about $1.4 \mathrm{ft}$ in $200 \mathrm{ft}$, or about $0.007 \mathrm{ft} / \mathrm{ft}$, which is similar to the gradient of Rapid Creek in the reach.
Cross-sectional water-table profiles near the gallery are shown in figure 30 . During nonpumpirg periods, line MBS- 1 to MBS-4 to MBN-8 had a gradient of about $0.002 \mathrm{ft} / \mathrm{ft}$, in a northerly directic n toward Rapid Creek, and line MBS-3 to MBS-4 to MBN-7 had a similar gradient, indicating a minor f 1 w component from the alluvium toward the creek. The gradient toward the creek could be caused by a small bedrock spring near the gallery. Both lines show a general gradient from the creek to the gallery during pumping periods.

Changes in water level with time in the alluvial aquifer near the gallery during the first cycling period of 1988 are shown in figure 31 . When gallery pumps were turned off, most of the recovery in the aquifer occurred in about 1 week, and complete stabilization required more than 2 weeks. When pumping was resumed, dewatering of the aquifer occurred more quickly than recovery. Many of the observation wells were completely dewatered (table 14), indicating that pumping capacity exceeds the capacity of the aquifer to transmit flow.

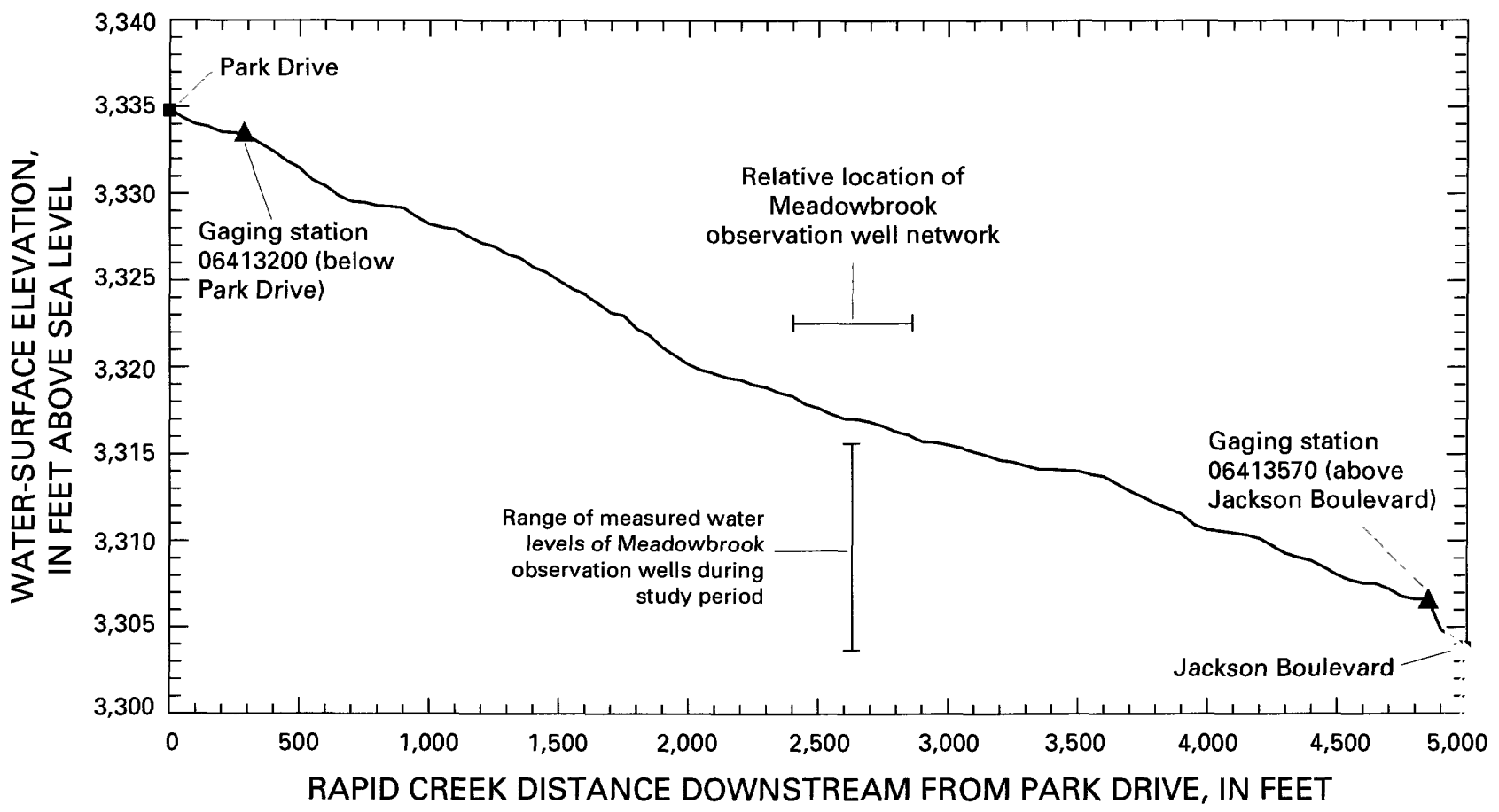

Figure 28. Profile of Rapid Creek water-surface elevation near Meadowbrook Gallery, July 31 to August 1, 1989. 


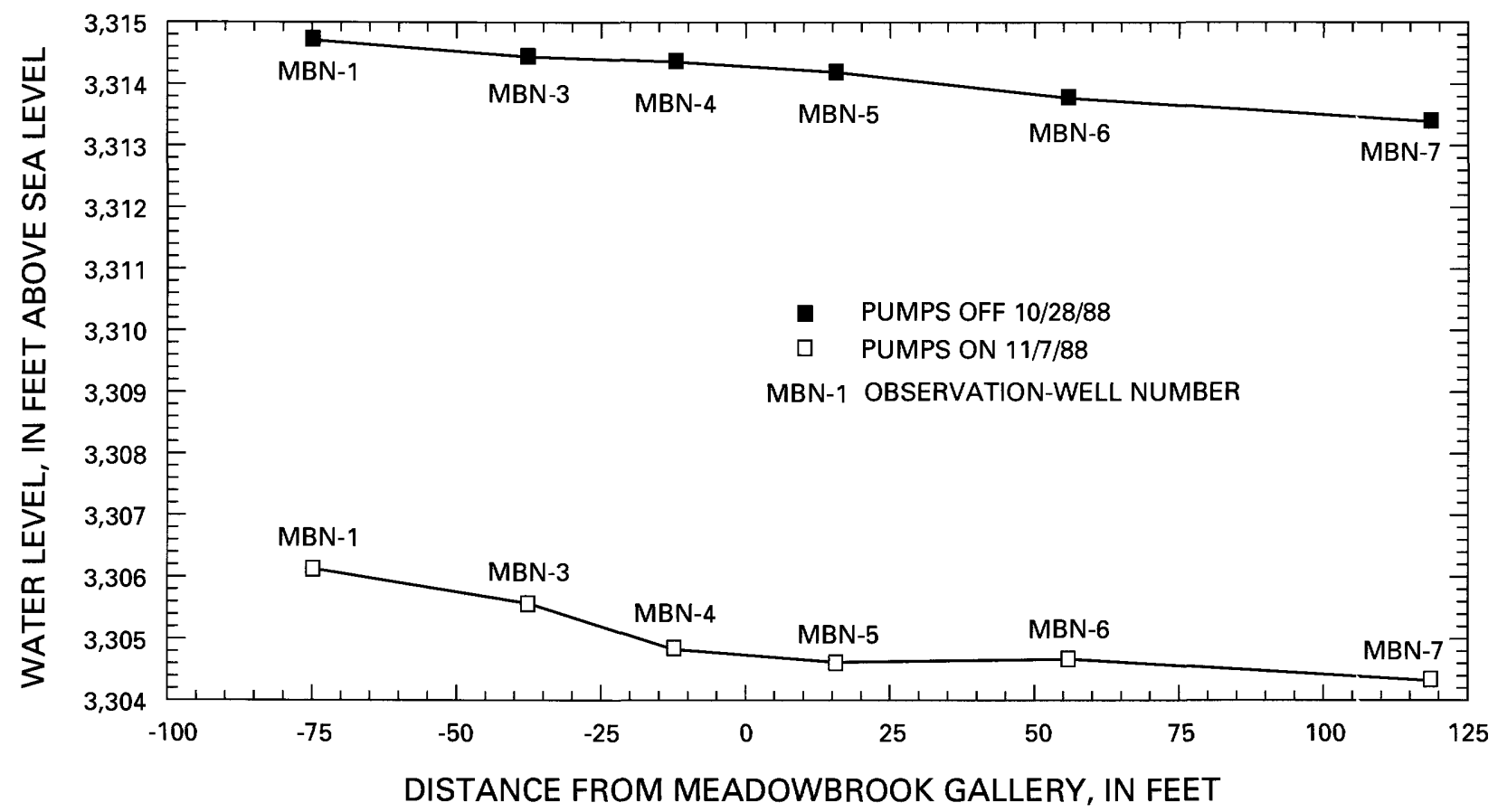

Figure 29. Longitudinal profile of alluvial water level during gallery cycling at Meadowbrook Gallery.

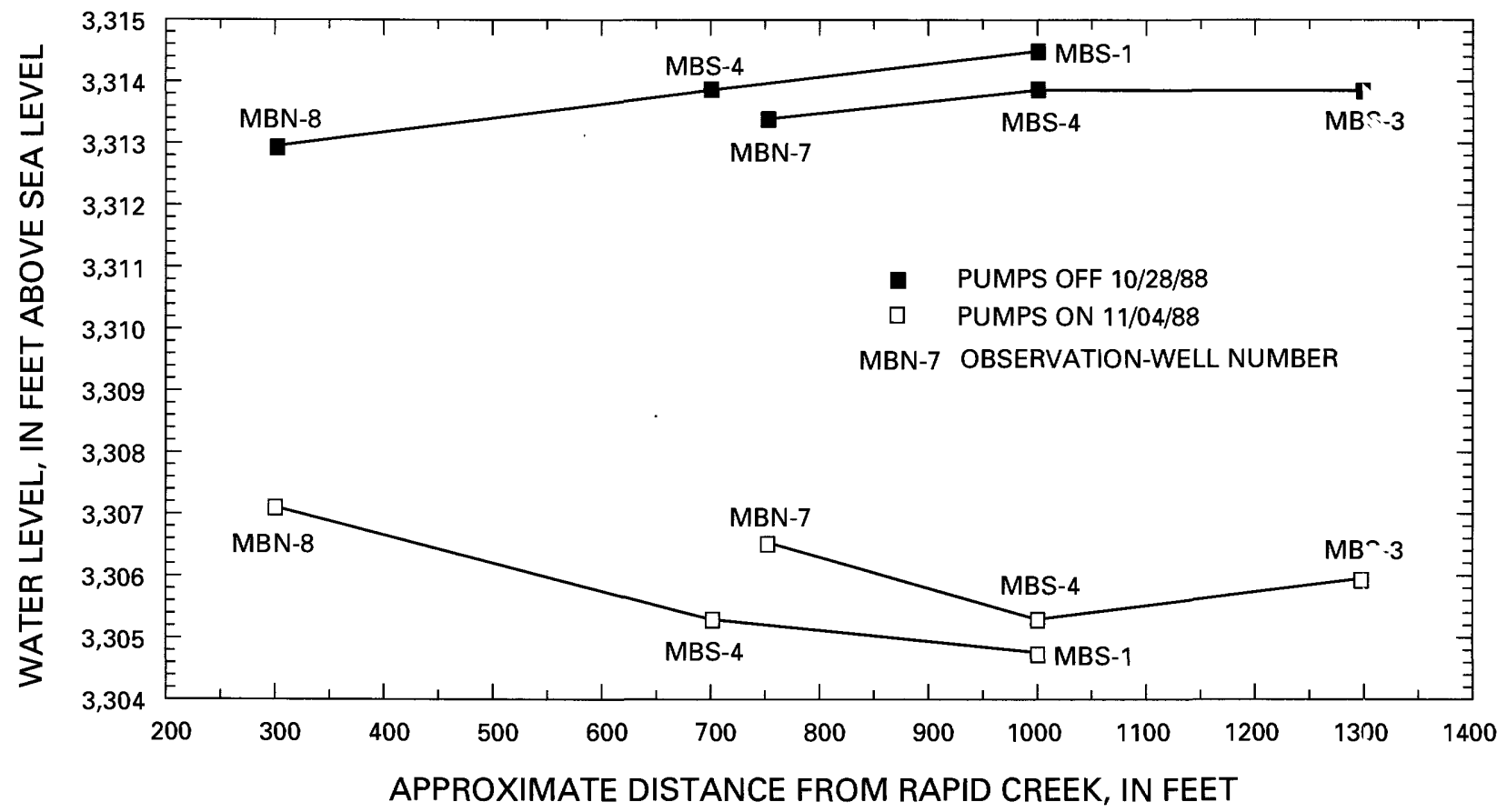

Figure 30. Cross-sectional profiles of alluvial water level during gallery cycling at Meadowbrook Gallery. 


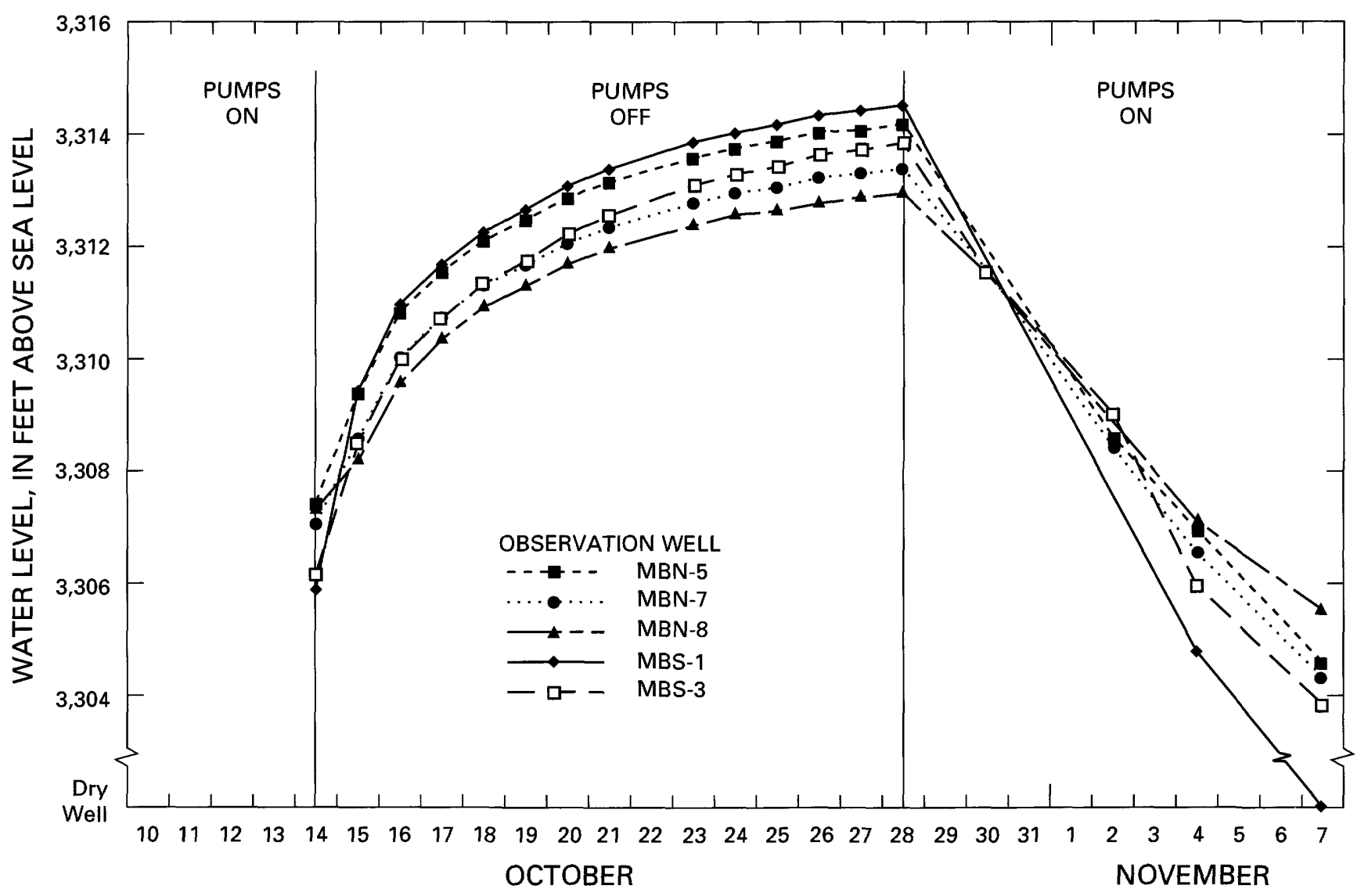

Figure 31. Measured water level of selected observation wells near Meadowbrook Gallery during gallery cycling, October 14 through November 7, 1988.

\section{Interactions with Rapid Creek}

The Meadowbrook Gallery was cycled five times during the study (fig. 11) to determine effects of gallery pumping on flow in Rapid Creek and Leedy Ditch (fig. 32). The gain (or loss) across Leedy Ditch (fig. 25 ) is calculated by subtracting upstream flow (station 06413300) from downstream flow of the ditch (station 06413550). The change in flow of Rapid Creek within the reach delimited by Leedy Ditch is calculated by subtracting the flow of Rapid Creek below Park Drive (station 06413200) from the computed flow of Rapid Creek just upstream from the mouth of Leedy Ditch (station 06413570 minus 06413550). The effects of gallery pumping on the creek are ambiguous for most of the periods of comparison; thus, no attempt is made to quantify the effects. Qualitatively, the flow of Rapid Creek increased by about the same magnitude as the change in pumping rate for two cycling periods during WY 1989.
The difficulty in quantifying the response of Rapid Creek probably results primarily from the long response time in the alluvial aquifer (fig. 31) as woll as the large area around the gallery that may be affe-ted by drawdown (fig. 28). Also, effects are more difficult to quantify than for the Jackson-Cleghorn reach because production of the Meadowbrook Gallery is only about one-half that of the Jackson Springs Gallery.

The Leedy Ditch loss rate shows no relation to the Meadowbrook Gallery pumping rate (fig. 32). Much of Leedy Ditch is located south of the alluvium (fig. 13), and the remainder generally is piped or lined; hence, the finding of no effect is consistent with the physical setting of the ditch.

\section{Hydrochemical Interpretations}

Hydrochemical signatures produced by dissolved oxygen and nitrogen, radium isotopes, and stable isotopes of oxygen and hydrogen were user to 

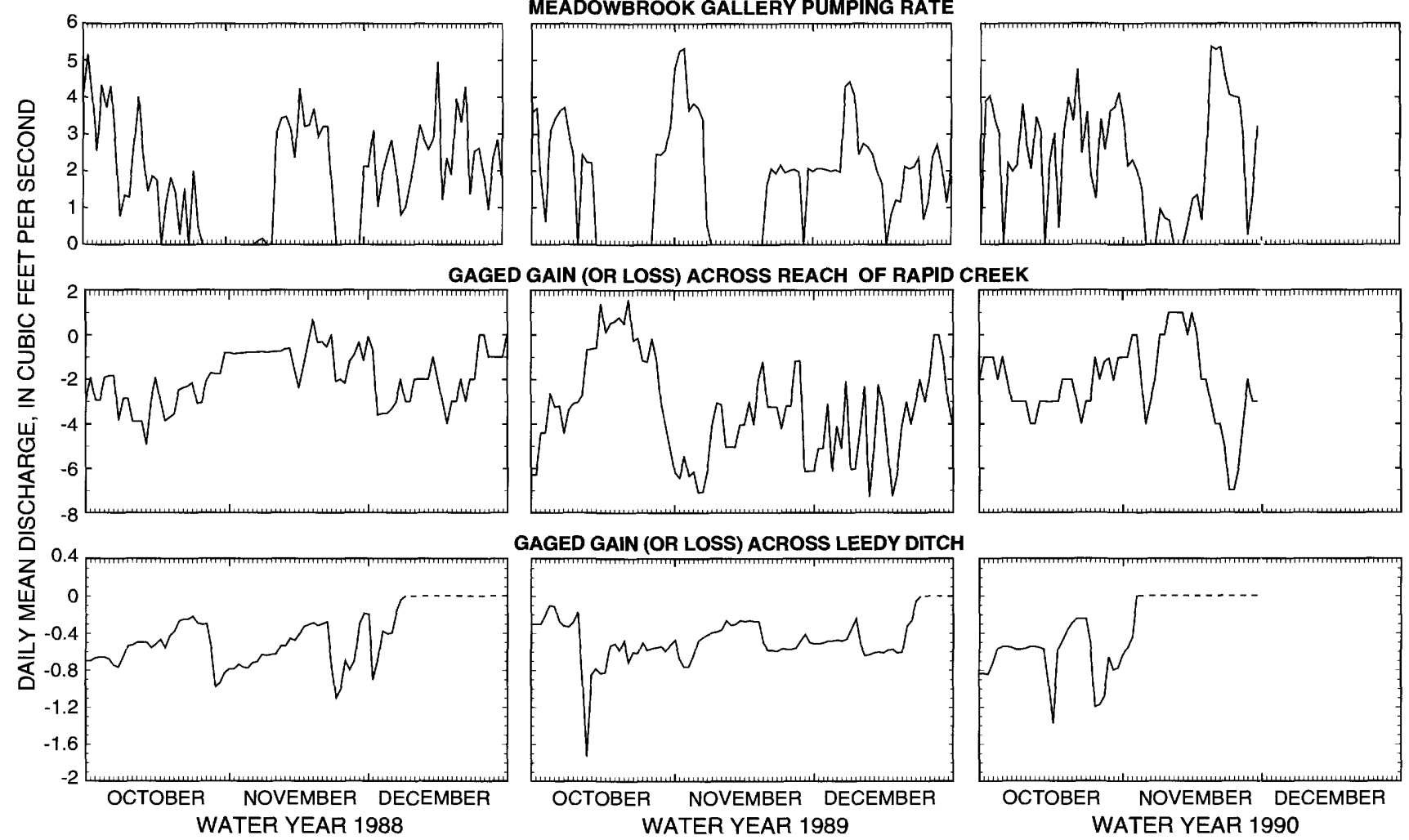

GAGED GAIN (OR LOSS) ACROSS LEEDY DITCH
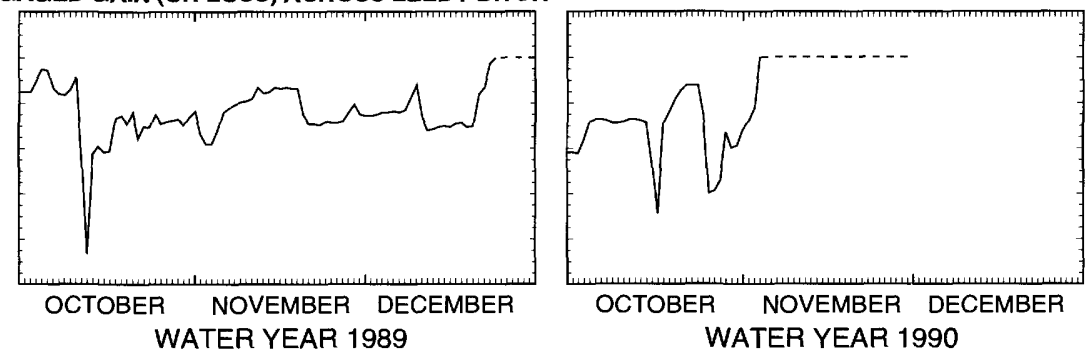

Figure 32. Comparison of Meadowbrook Gallery pumping rate, gaged gain (or loss) across reach, and gaged gain (or loss) across Leedy Ditch, October through December, water years 1988-90. Dashes indicate periods of no diversions to Leedy Ditch.

examine potential sources of water at the Meadowbrook Gallery. Gas-saturation values for the gallery and potential sources are shown in figure 33. The gradient from Rapid Creek to the gallery during pumping periods (figs. 28-30) indicates that flow occurs from the creek to the gallery. Nitrogen saturation, however, is larger for the Meadowbrook Gallery than in Rapid Creek (fig. 33), indicating that water from a bedrock source also may be present.

Activity levels of radium isotopes for selected sites are shown in figure 22 . The Ra-228/Ra-226 activity ratio was $1.01 \pm 0.022$ for water from the Meadowbrook Gallery (table 19), which is a distinct hydrochemical signature not replicated at any other site analyzed for this study. The activity ratio for Rapid Creek above Jackson Boulevard was 0.556 \pm 0.019 , indicating that the gallery water probably is not solely comprised of induced infiltration. Although production from the Meadowbrook Gallery may include a component of bedrock springflow, a second end member has not been identified. Thus, a mixing line for the Meadowbrook Gallery is not shown in figure 22.

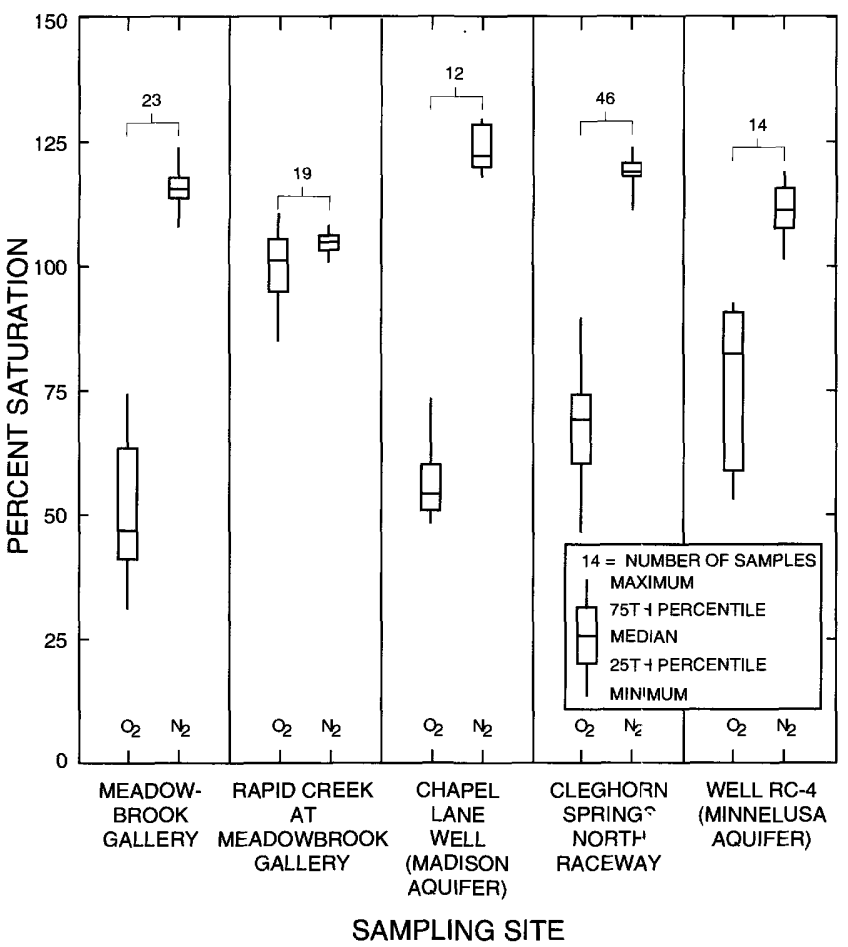

Figure 33. Percent saturation of dissolved oxygen and nitrogen for Meadowbrook Gallery and selected sites. 
Values for $\delta^{18} \mathrm{O}$ and $\delta \mathrm{D}$ for the Meadowbrook Gallery and potential sources of water for the gallery are shown in figure 34 . The mixing line for the gallery was drawn using water from Rapid Creek and Cleghorn Springs as end members. The isotopic composition of Rapid Creek varies seasonally as releases from Pactola Reservoir are changed in response to municipal and irrigation demand. In the summer when reservoir releases of isotopically light water are increased, the proportion of isotopically heavy water contributed to the creek by Jackson-Cleghorn Springs decreases. In response, the isotopic composition of Rapid Creek at the Meadowbrook pumphouse becomes lighter.

The isotopic composition of the gallery water also shifts from heavier in the winter to lighter in the summer (fig. 34), confirming that gallery pumping causes induced infiltration from Rapid Creek. During winter months, the isotopic composition of the gallery is very similar to that of Cleghorn Springs and Rapid Creek at the Meadowbrook pumphouse. During summer months, the gallery water becomes isotofically lighter but not as light as Rapid Creek at the Meadowbrook pumphouse, indicating a component of heavier water from some other source. Although the most probable source is upward leakage from either the Madison or Minnelusa aquifer, the aquifer cannot be determined from these data.

\section{Summary for Meadowbrook Gallery}

The Meadowbrook Gallery was constructed during 1950-52 in a marshy area around which the Meadowbrook Golf Course was later developed. Gallery production during WY 1988-89 averaged about 2,100 acre- $\mathrm{ft} / \mathrm{yr}$ (equivalent to $2.90 \mathrm{ft}^{3} / \mathrm{s}$ ). The control-volume analysis indicates that bedrock springflow averaged about 700 acre-ft/yr (equivalent to about $\left.1.0 \mathrm{ft}^{3} / \mathrm{s}\right)$. The standard error $( \pm 1,900 \mathrm{acre}-\mathrm{ft} / \mathrm{yr})$ is large, however, indicating that the uncertainty associated with the estimate is large.

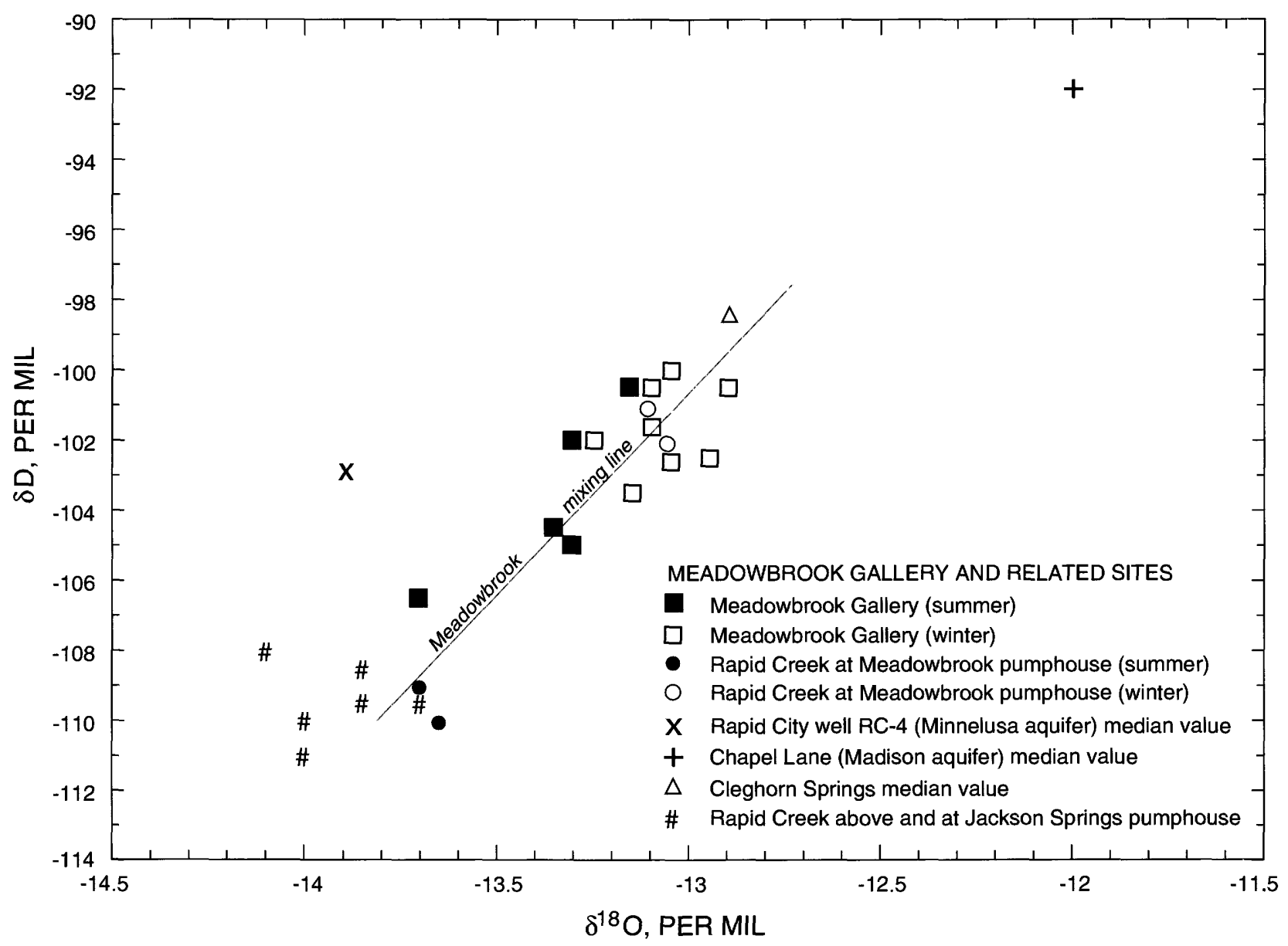

Figure 34. Relation between $\delta \mathrm{D}$ and $\delta^{18} \mathrm{O}$ for Meadowbrook Gallery. Potential sources of water are shown along with a mixing line for the gallery. Water produced by the gallery shifts along the mixing line seasonally. 
Pumping of the Meadowbrook Gallery induces a hydraulic gradient within the alluvial aquifer from Rapid Creek to the gallery, indicating that induced infiltration occurs. Maximum drawdown is about $10 \mathrm{ft}$; however, many of the observation wells are completely dewatered by sustained pumping. When pumps are turned off, alluvial water levels require about 2 weeks for complete recovery, after which a gradient is established from the alluvium to the creek, indicating possible bedrock springflow. The effects on Rapid Creek from gallery pumping are difficult to quantify because of the relatively small pumping rate and the long response time in the large alluvial area that is affected by drawdown. The flow of Leedy Ditch is not measurably affected by gallery pumping.

The Meadowbrook Gallery produces water that is supersaturated with respect to dissolved nitrogen and undersaturated with respect to dissolved oxygen. These dissolved gases and the radium isotopes indicate a possible component of springflow from underlying bedrock aquifers. The stable isotopes of oxygen and hydrogen in the gallery shifted from heavier in the winter to lighter in the summer in response to seasonal changes in isotopic composition of Rapid Creek. This response confirms the presence of creek water resulting from induced infiltration. The seasonal shift is smaller in the gallery than in the creek, however, again indicating a possible component of bedrock springflow. The combination of evidence indicates that although induced infiltration occurs, bedrock springflow probably is an additional source of water for the Meadowbrook Gallery.

\section{Girl Scout Gallery}

The Girl Scout Gallery (fig. 35) is located about $0.5 \mathrm{mi}$ downstream from the Meadowbrook Gallery (fig. 2) between Storybook Ditch and Rapid Creek. The gallery was constructed in 1960 on land once used as a Girl Scout camp. The gallery was under reconstruction from July 10, 1987, to April 28, 1988, to increase the production capacity by extending the subsurface laterals $300 \mathrm{ft}$ in each direction. The laterals are about $15 \mathrm{ft}$ below land surface.

\section{Control-Volume Analysis}

The Girl Scout control volume is defined as Rapid Creek and its alluvial aquifer from gaging station 06413570, Rapid Creek above Jackson Boulevard, to station 06413700, Rapid Creek above Water Treat- ment Plant (fig. 13). The surface area of th alluvial aquifer in this reach is about 310 acres. TT $\bullet$ width, hydraulic gradient, and transmissivity of t 1 alluvial aquifer are about $0.67 \mathrm{mi}, 0.0054 \mathrm{ft} / \mathrm{ft}$, and $10,000 \mathrm{ft}^{2} / \mathrm{d}$ at the upstream extent and $0.50 \mathrm{mi}, 0.0054 \mathrm{ft} / \mathrm{ft}$, and $5,000 \mathrm{ft}^{2} / \mathrm{d}$, respectively, at the downstream extent of the reach (Geibel, 1991).

Thickness and saturated thickness of the alluvial aquifer were determined for seismic-refraction profiles E-E' and F-F' (fig. 36) near the Girl Scout Gallery (fig. 35). The alluvial thickness varies from a few feet to about $20 \mathrm{ft}$, and the saturated thickness ranges from zero to about $15 \mathrm{ft}$. The seismic-refraction analysis and water-level measurements in observation wells near the gallery (table 15) indicate the depth to the water table is about 4 to $6 \mathrm{ft}$ when the gallery pumps are off.

Springflow entering the Girl Scout control volume was computed to be about 500 acre- $\mathrm{ft} / \mathrm{yr}$ (equivalent to about $0.7 \mathrm{ft}^{3} / \mathrm{s}$ ) for WY 1988-89 (fig. 37). Equation 8 was used for this anal''sis because of the diversion to Jackson Pond that occurs just upstream from gaging station 06413570. Flows of Storybook Ditch do not need to be accounted for because diversions and return flows both occur within the control volume. Values for other variables were obtained as previously described. Springf ow was computed by substituting the following values, which are shown with associated error terms, into equation 8:

$R C_{i}=29,375$ ( \pm 3 percent $)$, measured at station 06413570 ;

$D_{i}=100$ ( \pm 50 percent $)$, estimated for diversion to Jackson Pond;

$T_{i}=960( \pm 3$ percent $)$, measured at station

06413650 , plus 50 ( \pm 50 percent), estimated;

$P_{s a}=310$ ( \pm 25 percent $)$, estimated;

$A_{i}=1,600$ ( \pm 50 percent), estimated;

$R C_{o}=30,265$ ( \pm 3 percent $)$, measured at station 06413700 ;

$D_{o}=0$

$W_{s a}=881$ ( \pm 3 percent $)$, measured for Girl Scout Gallery

$E T_{\text {sa }}=1,100$ ( \pm 25 percent $)$, estimated; and $A_{o}=600$ ( \pm 50 percent $)$, estimated.

Thus, springflow $\left(S F_{i}\right)=451$ or 500 acre-ft/yr (rounded).

The standard error of the residual was computed using equation 6 . Thus, $S E_{S P R I N G}= \pm 1,600$ acre-ft/yr, which is large relative to the computed springflow into the reach. This indicates that the uncertainty associated with the estimate is large. 


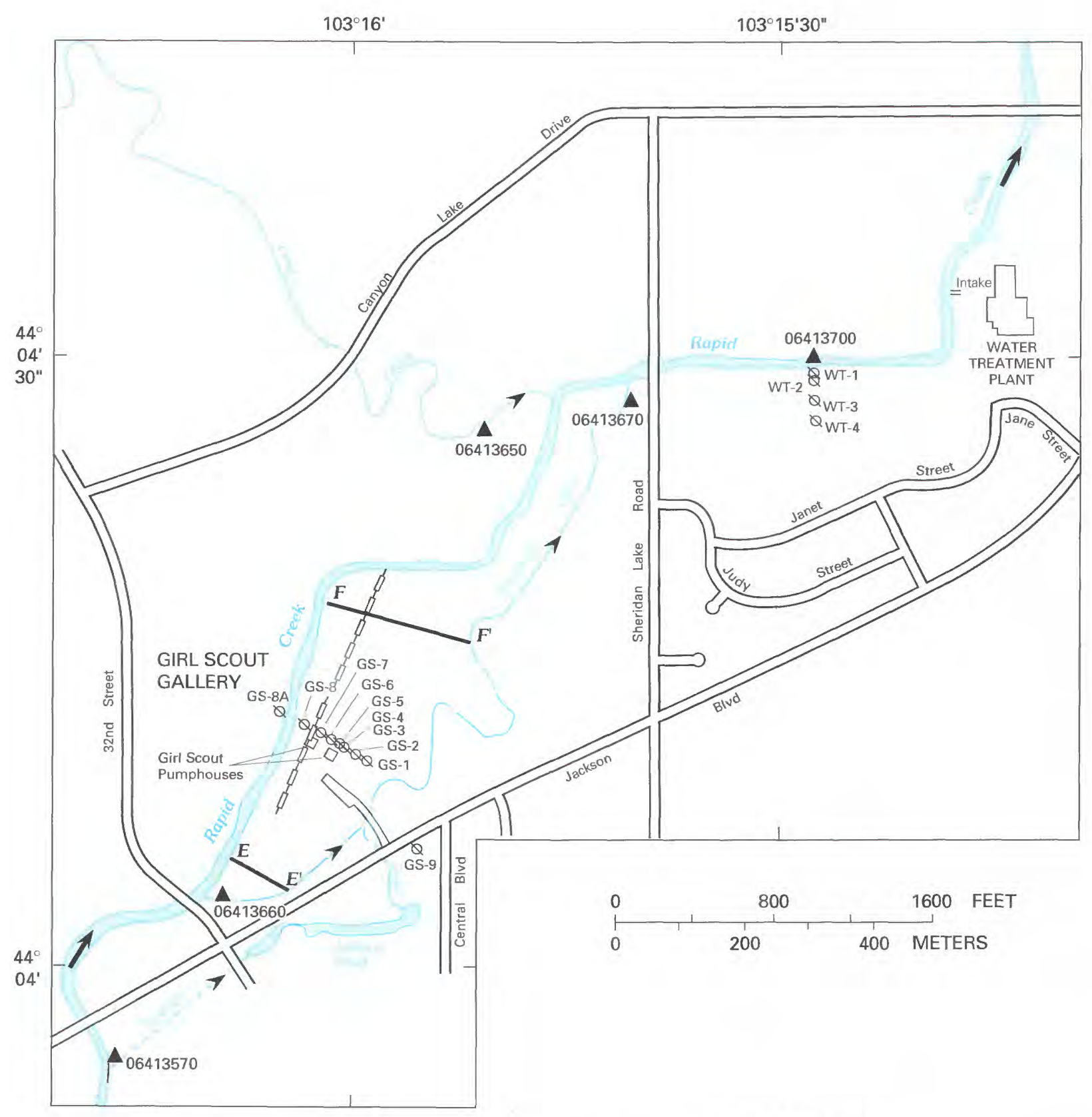

EXPLANATION

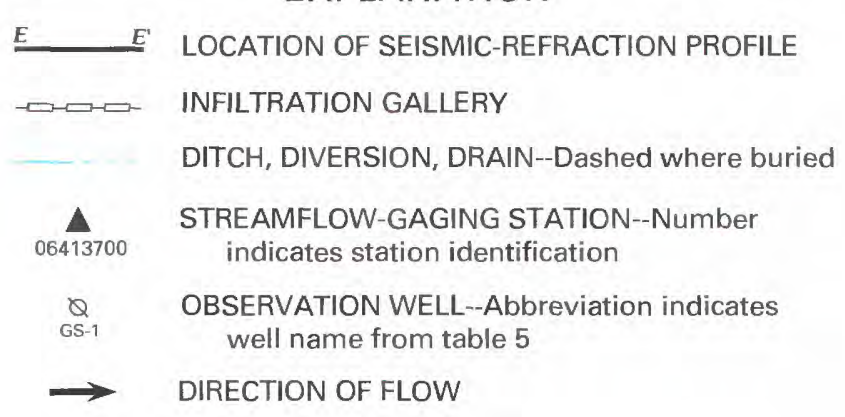

Figure 35. Girl Scout Gallery site. 

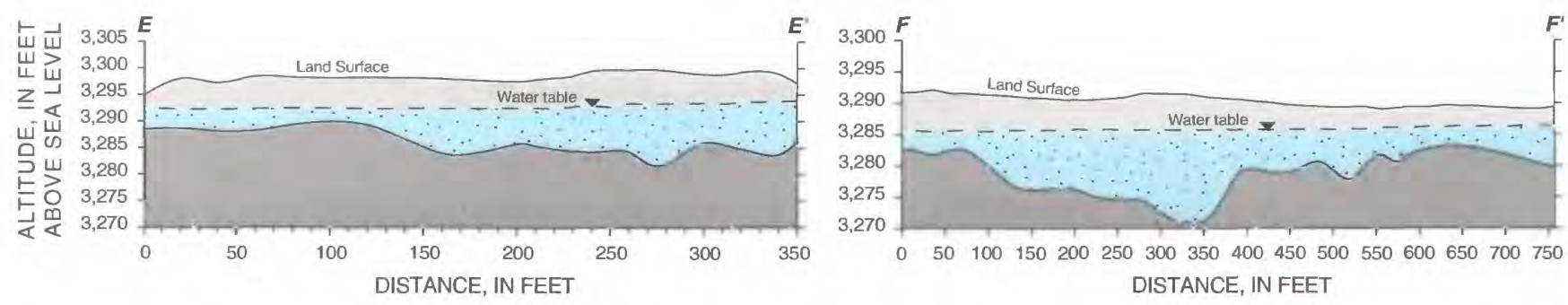

\section{EXPLANATION}

ALLUVIUM

BEDROCK

Unsaturated, average velocity $=1,050 \mathrm{ft} / \mathrm{s}$

Saturated, average velocity $=4,000 \mathrm{ft} / \mathrm{s}$

Figure 36. Geologic section from interpretation of Girl Scout seismic-refraction profiles (locations of sections shown in figure 35).

INFLOWS, IN ACRE-FEET PER YEAR

MEASURED:

Rapid Creek, 29,375

(Station 06413570)

Lime Creek, 960

(Station 06413650)

ESTIMATED:

Tributaries, 50

Alluvial inflow, 1,600

Precipitation, 310

Ditch inflow 100

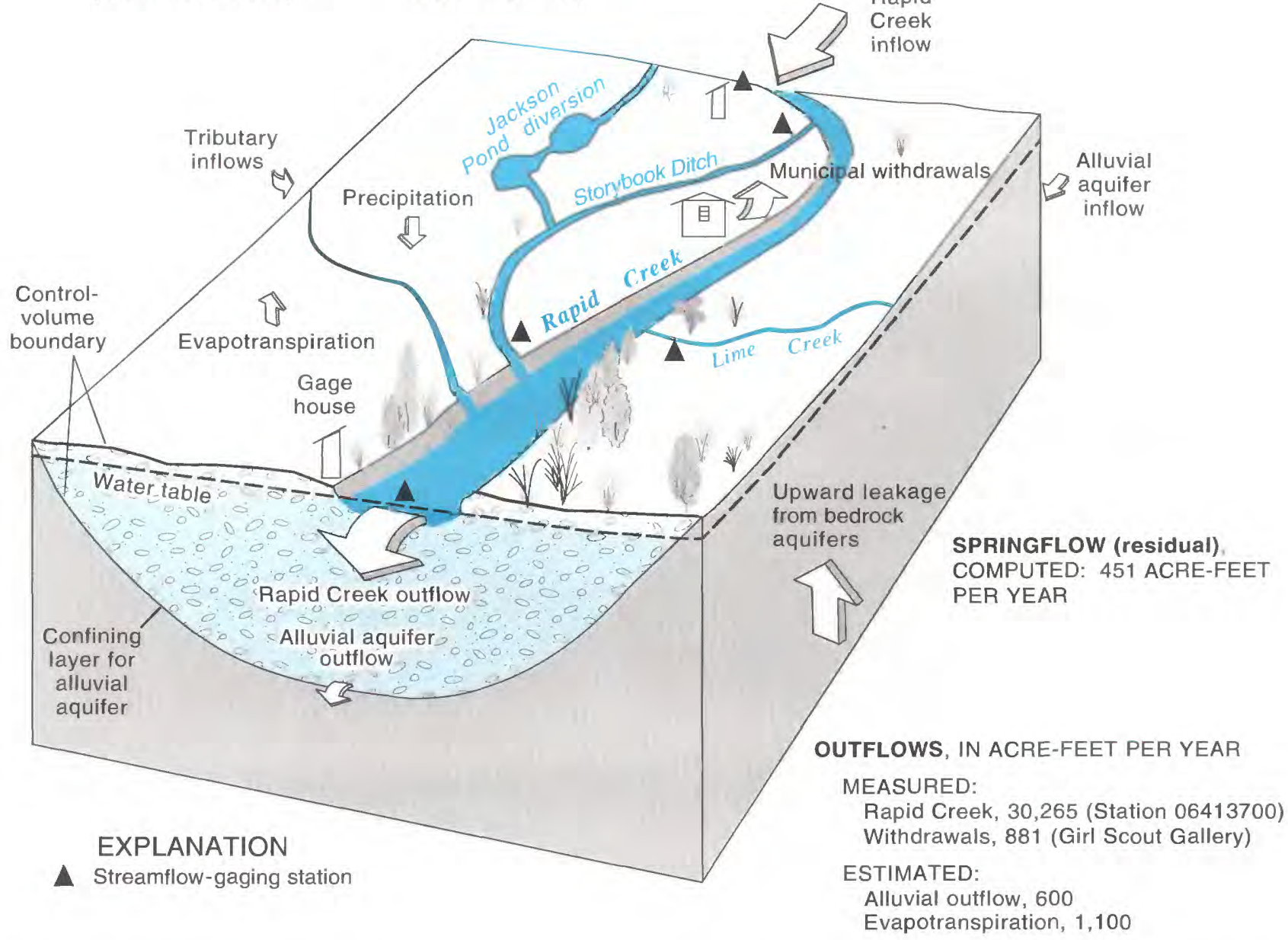

Figure 37. Control volume for Girl Scout Gallery showing mean annual inflows and outflows during water years 1988-89. 


\section{Interactions with Alluvial Aquifer}

Observation wells near the Girl Scout Gallery (fig. 35) provided information on effects of gallery pumping. Cross-sectional water-table profiles during pumping and nonpumping periods are shown in figure 38. During pumping periods, the gradient is from the creek to the gallery indicating that some flow is induced from the creek to the gallery.

As shown in figure 38, more than $2 \mathrm{ft}$ of drawdown occurred at well GS-8A (located across Rapid Creek from the gallery) at a maximum pumping rate of about $3 \mathrm{ft}^{3} / \mathrm{s}$. Thus, a limiting factor to the pumping rate of the Girl Scout Gallery may be the infiltration rate through the streambed of Rapid Creek. During nonpumping periods, a gradient existed from well GS-8A to both Rapid Creek and well GS-8. This indicates a possible spring source north of Rapid Creek, which is consistent with the control-volume analysis.

The response time for alluvial water levels (fig. 39) is longer than at Jackson Springs but shorter than at Meadowbrook. Most of the response at the Girl Scout Gallery occurred within 4 to 5 days, compared with 1 to 2 days at Jackson Springs and 1 to 2 weeks at Meadowbrook. None of the observation wells were completely dewatered by gallery pumping.

\section{Interactions with Rapid Creek}

The Girl Scout Gallery was cycled three times during the study (fig. 11) to determine effects of pumping on the flow in Rapid Creek and Storybook Ditch. Comparisons of gallery pumping and potential effects on flows in Rapid Creek and Storybook Ditch are shown in figure 40. The gain (or loss) of Rapid Creek within the reach delimited by Storybook Ditch (fig. 35) is calculated by subtracting the computed flow of Rapid Creek into the reach (station 06413570 minus 06413660) and inflow from Lime Creek (station 06413650) from the computed flow of Rapid Creek just upstream from the mouth of Storybook Ditch (station 06413700 minus 06413670). Data for WY 1988 are not presented because the Girl Scout Gallery was not in service during the fall of 1987. The effects of gallery pumping on Rapid Creek are evident in figure 40 but the effects are difficult to quantify. A complicating factor is that streamflow variability increases progressively in a downstream direction because of changing pumping rates in the Jackson Springs and Meadowbrook Galleries and changes in other upstream diversions.

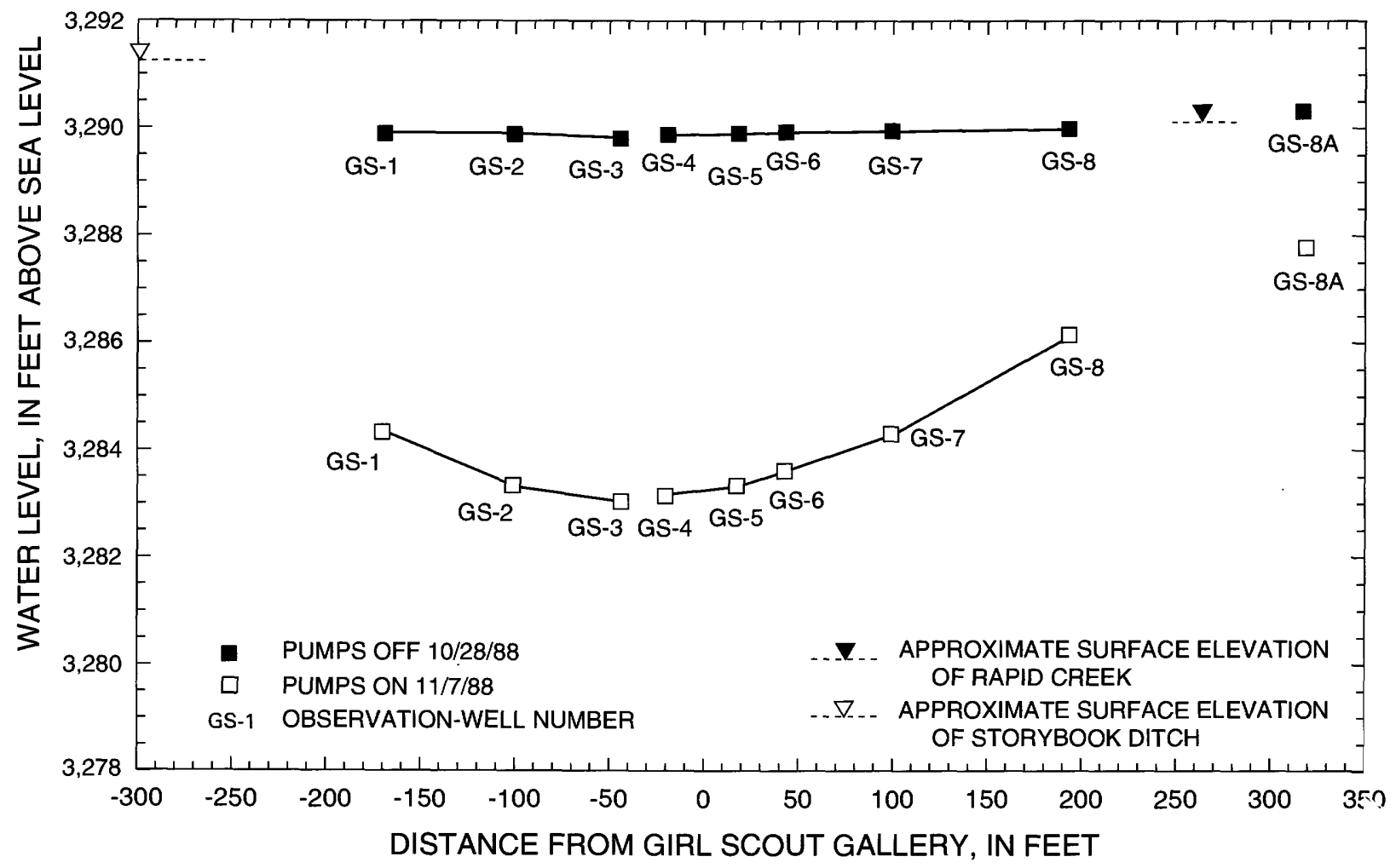

Figure 38. Cross-sectional profile of alluvial water level during gallery cycling at Girl Scout Gallery. 


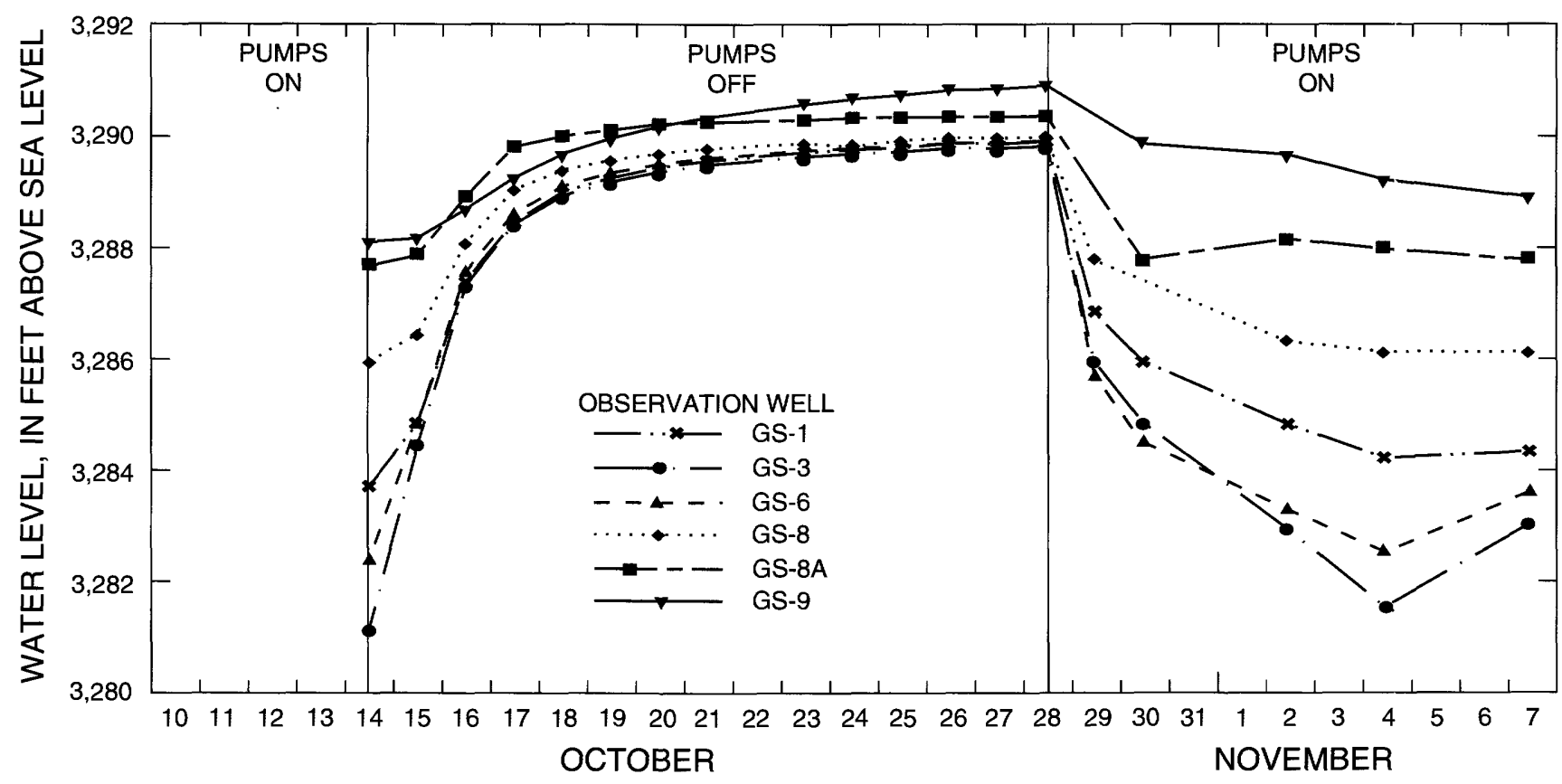

Figure 39. Measured water level of selected observation wells near Girl Scout Gallery during gallery cycling, October 14 through November 7, 1988.

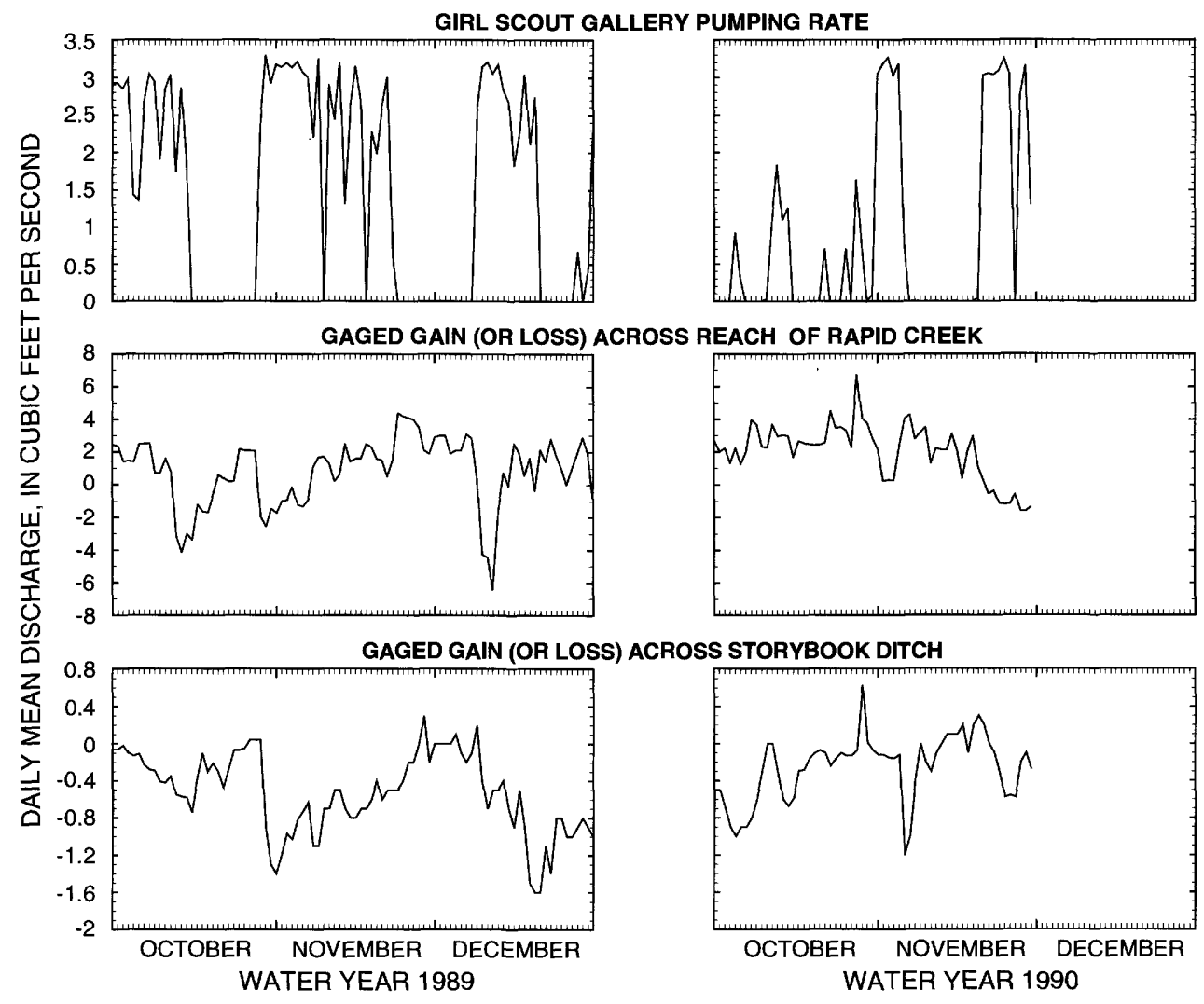

Figure 40. Comparison of Girl Scout Gallery pumping rate, gaged gain (or loss) across reach, and gaged gain (or loss) across Storybook Ditch, October through December, water years 1989-90. 
The loss rate across Storybook Ditch appears to be affected by pumping of Girl Scout Gallery, especially during the two cycling periods during WY 1989 (fig. 40). Storybook Ditch is constructed within the extent of the alluvial aquifer (fig. 13) and is sufficiently close to the gallery to be within the zone of influence of drawdown induced by pumping (fig. 38). A Wilcoxon-Mann-Whitney rank-sum test (Iman and Conover, 1983) was used to test for statistical significance between the median loss rate for pumping and nonpumping periods for each of the three cycling periods during WY 1989-90. The test results confirmed (at a 99-percent confidence level) that pumping of the Girl Scout Gallery affects flow in Storybook Ditch. The average change in loss rate of the ditch for the three cycling periods was about $0.5 \mathrm{ft}^{3} / \mathrm{s}$ in response to an average change in pumping rate of about $2.6 \mathrm{ft}^{3} / \mathrm{s}$.

\section{Hydrochemical Interpretations}

Hydrochemical signatures produced by dissolved oxygen and nitrogen, radium isotopes, and stable isotopes of oxygen and hydrogen were used to examine potential sources of water at the Girl Scout Gallery. Gas-saturation values for the gallery and potential sources are shown in figure 41 . The gradient from Rapid Creek to the gallery during pumping periods (fig. 38) indicates that flow occurs from the creek to the gallery. Nitrogen saturation, however, is larger for the gallery than in Rapid Creek (fig. 41), indicating that water from a bedrock source also may be present. Dissolved oxygen saturation for the Girl Scout Gallery (fig. 41) is notably lower than for the Jackson Springs and Meadowbrook Galleries (figs. 21 and 33).

Activity levels of radium isotopes for selected sites in western Rapid City are shown in figure 22 . The $\mathrm{Ra}-228 / \mathrm{Ra}-226$ activity ratio was $0.799 \pm 0.038$ for water from the Girl Scout Gallery and was $0.556 \pm$ 0.019 for Rapid Creek above Jackson Boulevard (table 19). This indicates the gallery water probably does not consist solely of induced infiltration. The closest Minnelusa aquifer observation well to the Girl Scout Gallery is Sioux Park observation well No. 1 (fig. 12, table 6). The activity ratio for the Girl Scout Gallery is very similar to the ratio of $0.742 \pm 0.041$ for this well (table 19), which may suggest springflow from the Minnelusa aquifer to the gallery.

Values for $\delta^{18} \mathrm{O}$ and $\delta \mathrm{D}$ for the Girl Scout Gallery and potential sources of water for the gallery are shown in figure 42 . All values for the gallery are within the

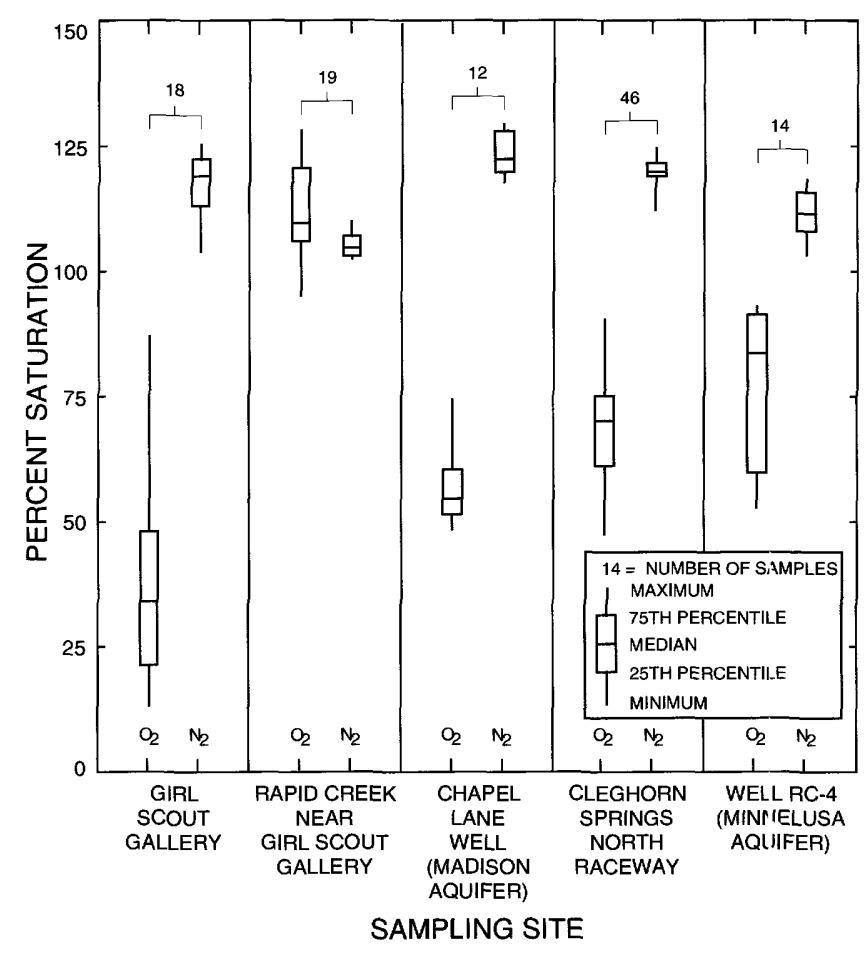

Figure 41. Percent saturation of dissolved oxygen and nitrogen for Girl Scout Gallery and selected sites.

range measured for the creek. The creek water varies seasonally from isotopically heavier in the winter to lighter in the summer in response to larger releases of lighter water from Pactola Reservoir during the summer. The mixing line in figure 42 shows that this seasonal variation also is apparent for the Girl Scout Gallery. Although the effect is less pronounced than for the Meadowbrook Gallery, this seasonal variation provides further evidence that the Girl Scout Gallery induces infiltration from Rapid Creek.

\section{Summary for Girl Scout Gallery}

The Girl Scout Gallery was constructed in 1960 at the site of a former Girl Scout camp between F apid Creek and Storybook Ditch. Gallery production d uring WY 1988-89 averaged about 880 acre-ft/yr (equivalent to $1.2 \mathrm{ft}^{3} / \mathrm{s}$ ). The control-volume analysis indicates that bedrock springflow averaged about 500 acre- $\mathrm{ft} / \mathrm{yr}$ $\left(0.7 \mathrm{ft}^{3} / \mathrm{s}\right)$. The standard error $( \pm 1,600$ acre- $\mathrm{ft} / \mathrm{yr})$ is large, however, indicating that the uncertainty associated with the estimate is large.

Pumping of the Girl Scout Gallery induces a hydraulic gradient within the alluvial aquifer from both Rapid Creek and Storybook Ditch toward the gallery. Drawdown from gallery pumping extends beyond Rapid Creek. When pumps are turned off, alluvial 


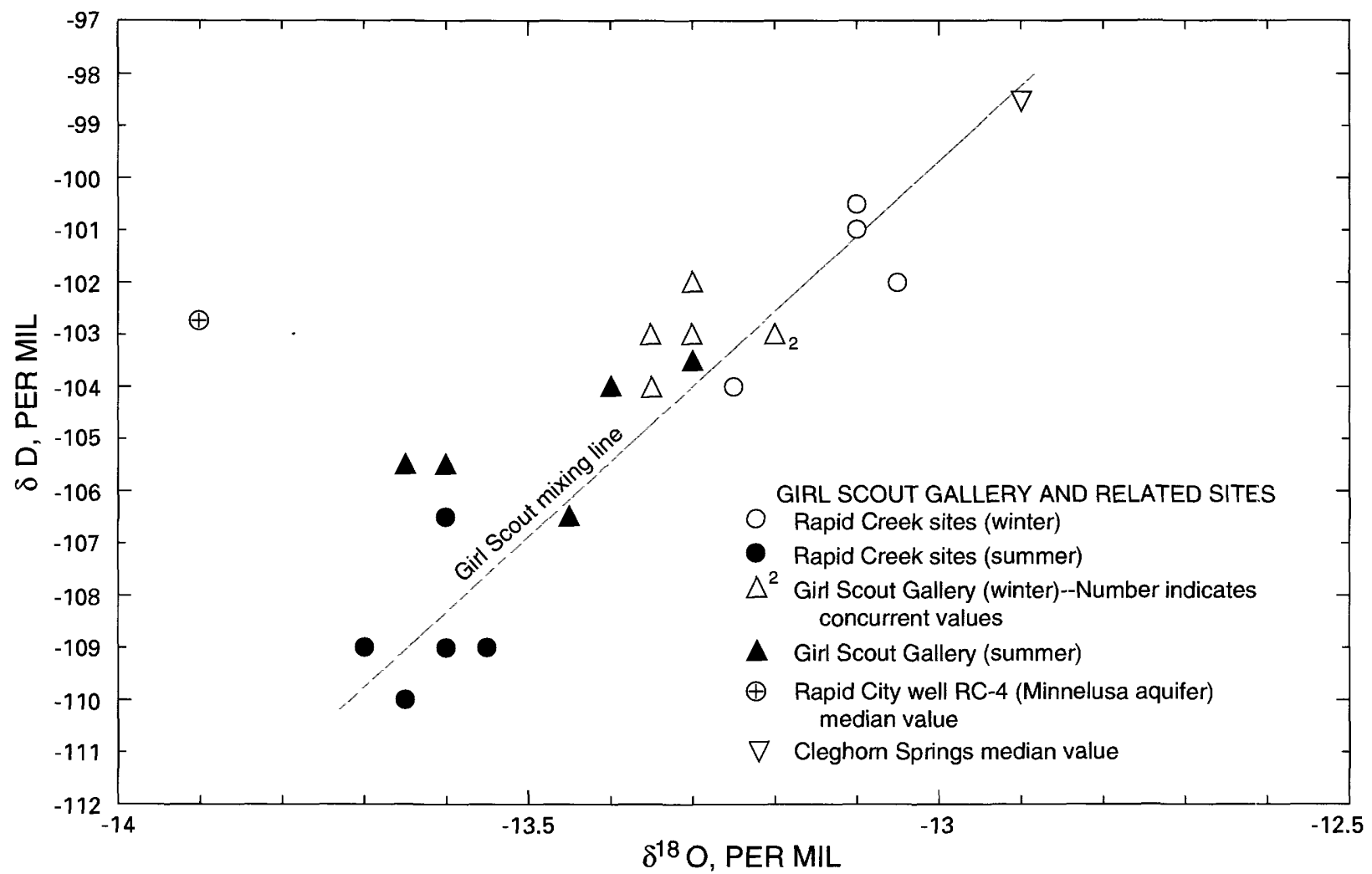

Figure 42. Relation between $\delta \mathrm{D}$ and $\delta^{18} \mathrm{O}$ for Girl Scout Gallery. Potential sources of water are shown alcng with a mixing line for the gallery. Rapid Creek sites include Rapid Creek at Meadowbrook pumphouse and Rapid Creek near Girl Scout Gallery.

water levels recover within about 4 to 5 days. The response of Rapid Creek to changing pumping rates generally is discernible in comparison hydrographs (fig. 40); however, effects are difficult to quantify because of relatively small pumping rates and large streamflow variability that results from upstream influences. The effect on Storybook Ditch was quantified, however, and the loss rate changed by about $0.5 \mathrm{ft}^{3} / \mathrm{s}$ in response to an average change in pumping rate of about $2.6 \mathrm{ft}^{3} / \mathrm{s}$.

Like the Meadowbrook Gallery, the Girl Scout Gallery produces water that is supersaturated with respect to dissolved nitrogen and undersaturated with respect to dissolved oxygen. These dissolved gases and the radium isotopes indicate that a component of bedrock springflow may be present at the gallery. The stable isotopes of oxygen and hydrogen in the gallery shifted seasonally in response to changes in isotopic composition of Rapid Creek, confirming the presence of creek water resulting from induced infiltration. The combination of evidence indicates that production of the Girl Scout Gallery consists of induced infiltration from Rapid Creek and Storybook Ditch mixed with a probable component of bedrock springflow.

\section{HYDROLOGIC BUDGET FOR RAPIJ CREEK}

Hydrologic budgets for WY 1988-8C were developed for five subreaches of Rapid Creek, delimited by six streamflow gages, between Pactola Reservoir and central Rapid City (fig. 43). Ground-water seepage was computed as a residual using equation 5 , which accounts for direct surface inflows, outflow's, and withdrawals within each subreach. Thus, the seepage term accounts for interactions with all hydrogec' ogic units adjacent to Rapid Creek, including both alluvial deposits and bedrock units. Although ground-water withdrawals are not considered in equation 5, seepage is affected by ground-water withdrawals that cause induced infiltration from Rapid Creek. A positive residual indicates seepage to the creek (straamflow gains), and a negative residual indicates se spage from the creek (streamflow losses). The standard error for each subreach was computed using equation 6. 


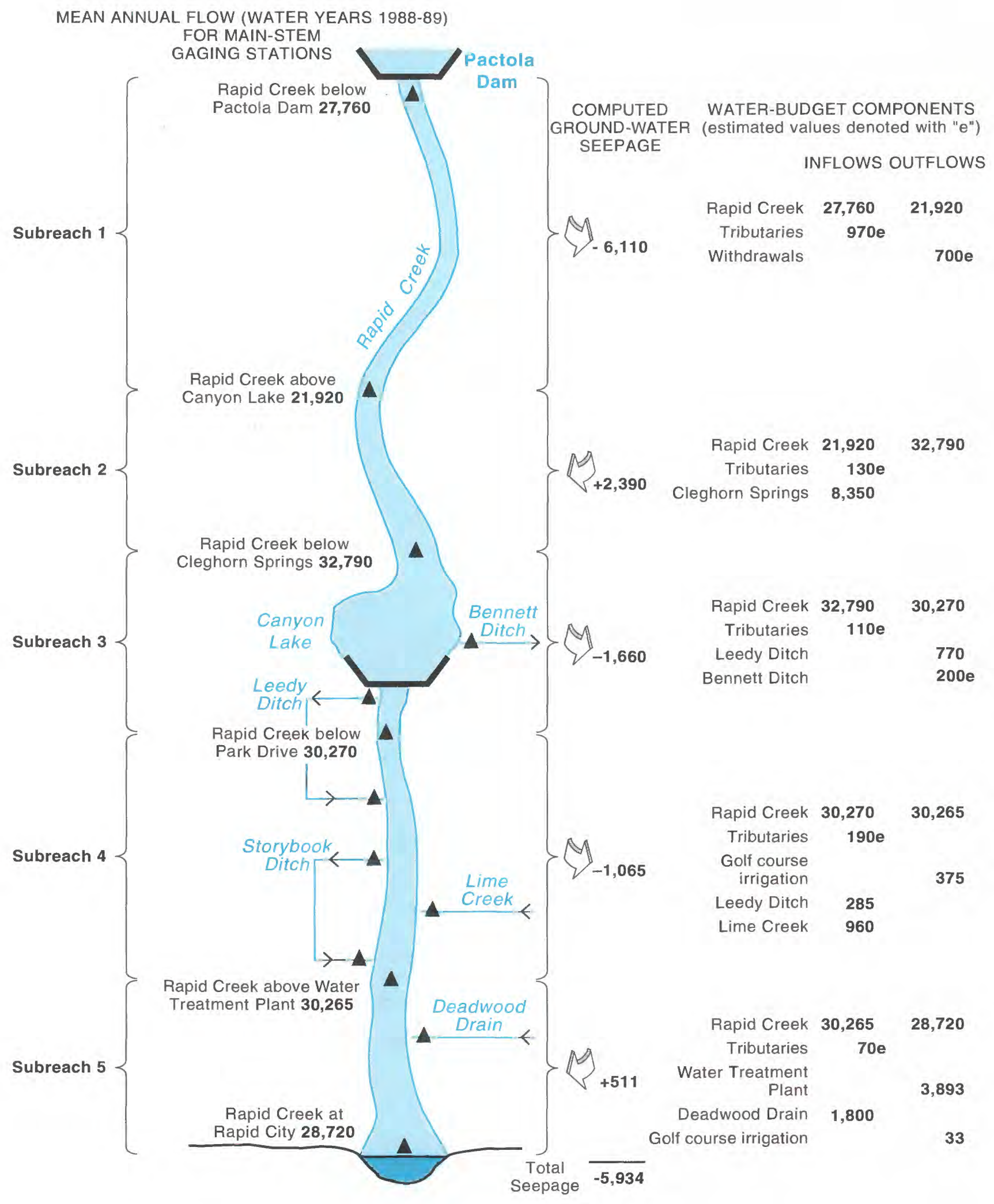

Figure 43. Hydrologic budget for Rapid Creek between gaging stations 06411500 (below Pactola Dam) and 06414000 (at Rapid City), water years 1988-89. All values are mean annual values in acre-feet per year. 
The hydrologic budgets are representative of dry climatic conditions because precipitation during WY 1988-89 was about 70 percent of the long-term average for Rapid City. Estimates of ungaged tributary inflows, which were computed as 3 percent of the average annual precipitation, are about 30 percent smaller than for average conditions. Other components of the hydrologic budgets, including withdrawals, diversions, and computed seepage values, probably are representative of dry climatic conditions rather than average conditions.

Subreach 1 is defined as the reach from station 06411500, Rapid Creek below Pactola Dam, to station 06412500, Rapid Creek above Canyon Lake (figs. 2 and 43). Ground-water seepage for subreach 1 was computed as $-6.110( \pm 1,200)$ acre-ft/yr (equivalent to an average loss rate of $8.4 \mathrm{ft}^{3} / \mathrm{s}$ ), indicating that net ground-water recharge occurs.

In the upstream part of subreach 1, Rapid Creek is incised into Precambrian metamorphic rocks (fig. 3) of relatively low permeability; thus, interactions with ground water are relatively small. Numerous residents in this area utilize water from Rapid Creek, or from shallow wells near the creek, for lawn watering and other domestic uses. Estimated withdrawals are based on 700 residences using 1 acre-ft of water per year, assuming that withdrawals are directly from Rapid Creek.

The downstream part of subreach 1 includes outcrops of various Paleozoic rocks (fig. 3, table 1), of which the Madison Limestone and Minnelusa Formation are of particular hydrologic importance. Significant streamflow losses to these units have been documented by numerous investigators. Driscoll (1987) and Peter (1985) estimated net streamflow losses from Rapid Creek to be about 4 and $6 \mathrm{ft}^{3} / \mathrm{s}$, respectively, using methods that did not account for tributary inflows or withdrawals. Hines (1991) determined from five separate series of streamflow measurements that losses occurred primarily to the Madison Limestone, with minor losses to the Minnelusa Formation. Total losses ranged from 7.1 to $11 \mathrm{ft}^{3} / \mathrm{s}$ with an average of $8.8 \mathrm{ft}^{3} / \mathrm{s}$. These values agree well with the computed loss rate of $8.4 \mathrm{ft}^{3} / \mathrm{s}$ for subreach 1. Hines also used radon gas analysis to identify several zones of significant ground-water discharge (springflow) within this reach.

Gaging station 06412200, Rapid Creek above Victoria Creek, also is located within subreach 1 (fig. 2) near the contact between the Precambrian and Paleozoic rocks (fig. 3). This station was not used for the hydrologic budgets because streamflow records are not available for WY 1988 (table 7). Records for WY 1989-90, however, indicate that interactions with ground water are minimal in the upstream part of subreach 1. Streamflow in the downstream part of subreach 1 (between stations 06412200 and 06412500 ) decreased by an average of 6,380 acre- $\mathrm{ft} / \mathrm{yr}$ for WY 1989-90 (table 7) without accounting for tributary inflows or withdrawals, both of which probably were minimal in this reach. This agrees well with the computed loss rate of 6,110 acre-ft/yr for WY 1988-89 for subreach 1 .

Water-level data collected at a pool within Brooks Cave (fig. 2) show a distinctive annual pattern that corresponds somewhat with changes in flow (or stage) of Rapid Creek (fig. 44). Brooks Cave is a solution cave in the Madison Limestone, with passageways that extend to the water table in the Madison aquifer (fig. 45). Numerous solution features are visible along the streambed of Rapid Creek in the outcrop of the Madison Limestone, which occurs between elevations of about 3,420 and 3,500 ft above sea level. The water level of the pool in Brooks Cave is near the center of this range and generally fluctuates between about 3,455 and 3,463 ft above sea level. Maximum water levels during WY 1989-90 (fig. 44), as well as during several subsequent years (Driscoll and others, 1996), are very similar and appear to be somewhat independent of flow in Rapid Creek. This may indicate that, above some fixed elevation, the pool spills into an adjacent opening.

The rapid change in water levels in Brooks Cave could indicate that losses from Rapid Creek increase with increasing streamflow. Previous investigators (Peter, 1985; Driscoll, 1987), however, have found no correlation between loss rates and streamflow. Thus, variations in loss rates may be very small. Another possibility is that increased losses may be balanced by increased springflow within this reach. Hines (1991) documented springflow at various locations such as Tittle Springs (fig. 2) within this reach.

Subreach 2 is the reach from station 06412500 , Rapid Creek above Canyon Lake, to station 06412900, Rapid Creek below Cleghorn Springs (figs. 2 and 43). In this reach, Rapid Creek gained 2,390 $( \pm 1,200)$ acre$\mathrm{ft} / \mathrm{yr}\left(3.3 \mathrm{ft}^{3} / \mathrm{s}\right)$ from ground-water seepage, in addition to 8,350 acre- $\mathrm{ft} / \mathrm{yr}\left(11.5 \mathrm{ft}^{3} / \mathrm{s}\right)$ from the outfall of Cleghorn Springs Fish Hatchery. These inflows are springflow from the Madison aquifer, which also is the primary source of water for the Jackson Springs Gallery. 


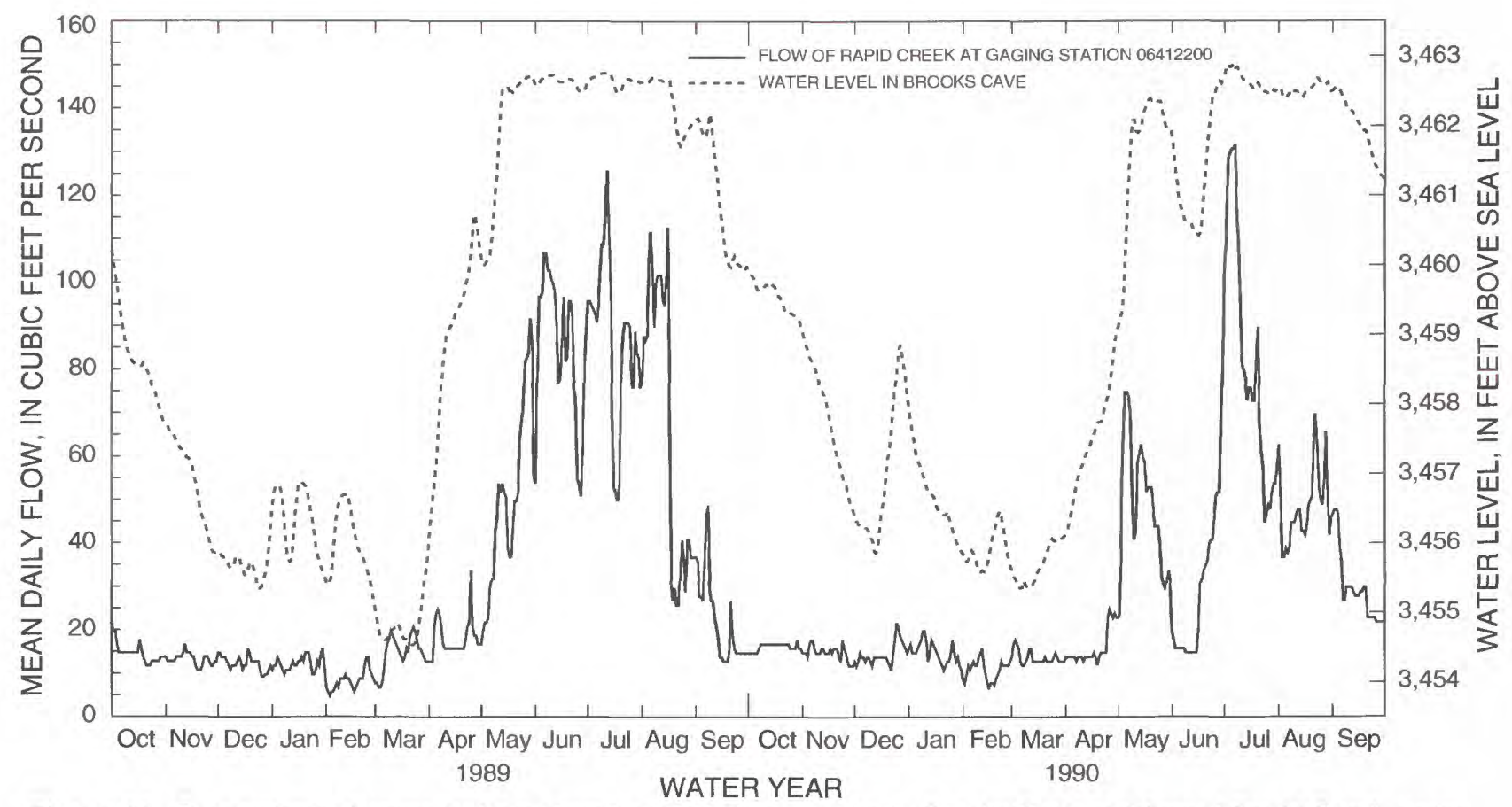

Figure 44. Comparison of water-surface elevation of Madison aquifer in Brooks Cave and flow of Rapid Creek, water years 1989-90.

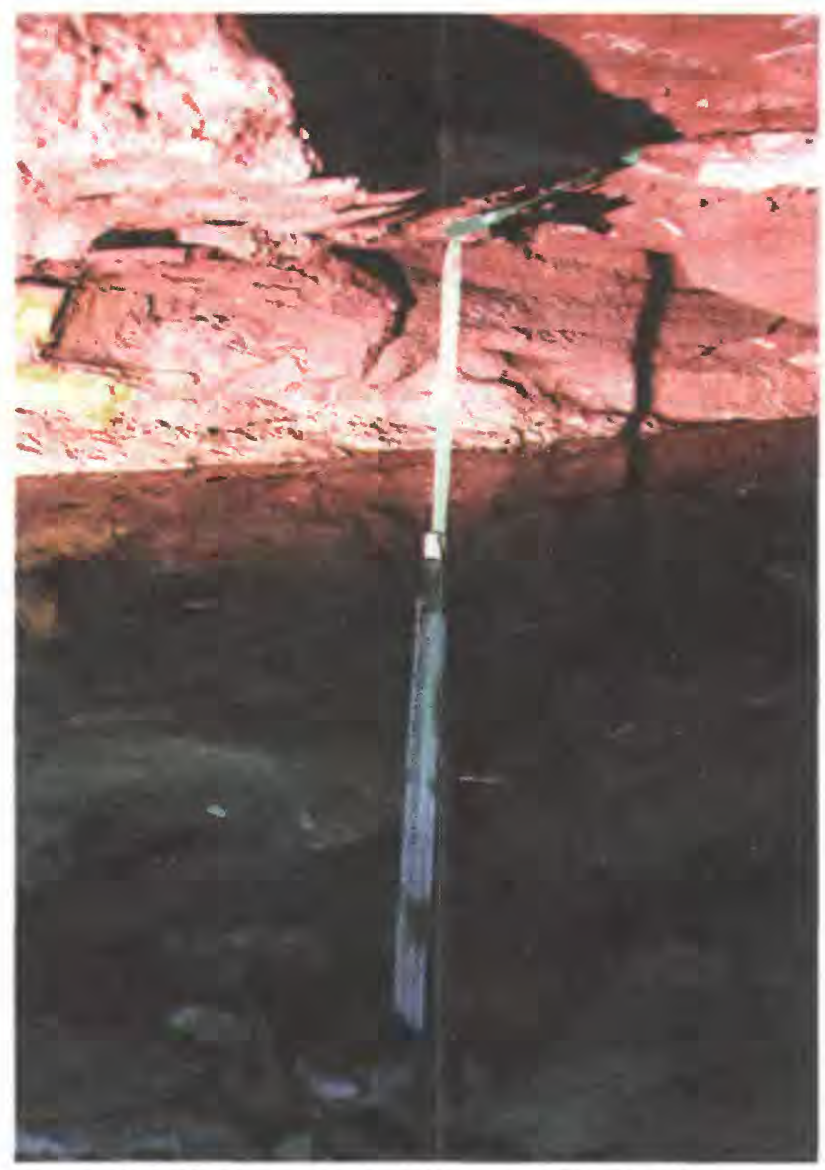

Figure 45. Photograph of staff gage in Brooks Cave.
Subreach 3 is the reach from station 06412900 , Rapid Creek below Cleghorn Springs, to station 06413200, Rapid Creek below Park Drive (figs. 2 and 43). In this reach, Rapid Creek lost $1,660( \pm 1,300)$ acre- $\mathrm{ft} / \mathrm{yr}\left(2.3 \mathrm{ft}^{3} / \mathrm{s}\right)$ to ground-water seepage.

Although the standard error is relatively large, there are two plausible explanations for seepage to ground water in this reach. Extensive seepage may occur to alluvial deposits, which increase in width immediately downstream from Canyon Lake Dam (fig. 13). Recharge also may occur to the Minnekahta Limestone, Opeche Shale, and Minnelusa Formation, which are exposed within this reach. An observation well completed in the Minnelusa aquifer is located just north of Canyon Lake, immediately adjacent to a well completed in the Madison aquifer (site 16 in fig. 12). The water level in the Minnelusa well is approximately equal to the watersurface elevation of Canyon Lake and may be affected by the level of the lake (Driscoll and others, 1996).

Subreach 4 is the reach from station 06413200 , Rapid Creek below Park Drive, to station 06413700 , Rapid Creek above Water Treatment Plant (figs. 2 and 43). In this reach, Rapid Creek lost 1,065 ( $\pm 1,300)$ acre- $\mathrm{ft} / \mathrm{yr}\left(1.5 \mathrm{ft}^{3} / \mathrm{s}\right)$ to ground-water seepage.

Numerous surface-water influences occur in this reach. Measured tributary inflows include Lime Creek and the 
return flows of Leedy Ditch. Direct withdrawals for irrigation of the Meadowbrook and Arrowhead Golf Courses also occur within this reach. The diversion and return flow of Storybook Ditch are excluded from the analysis because withdrawals from the ditch are negligible. Computed seepage to ground water probably results from infiltration induced by pumping of the Meadowbrook and Girl Scout Galleries, which averaged 2,980 acre- $\mathrm{ft} / \mathrm{yr}\left(4.1 \mathrm{ft}^{3} / \mathrm{s}\right)$ for WY $1988-89$ (table 3). This is consistent with the results of controlvolume and hydrochemical analyses presented earlier, which indicated that the source of water to both galleries is a combination of induced infiltration from Rapid Creek and bedrock springflow.

Subreach 5 is the reach from gaging station 06413700, Rapid Creek above Water Treatment Plant, to station 06414000, Rapid Creek at Rapid City (figs. 2 and 43). In this reach, Rapid Creek gained 511
$( \pm 1,300)$ acre- $\mathrm{ft} / \mathrm{yr}\left(0.7 \mathrm{ft}^{3} / \mathrm{s}\right)$ from ground-water seepage. Because the standard error is much larger than the residual, this is considered an equilibrium reach relative to ground-water interaction. Large surface withdrawals are made at the Water Treatment Plant, and the Deadwood Avenue Drain is a perennial tributary within the reach.

In subreach 5, Rapid Creek interacts with the adjacent alluvial aquifer without the complicating influence of gallery withdrawals. Continuous records were collected for selected periods for a line of four observation wells located south of Rapid Creek adjacent to gaging station 06413700 (fig. 35). Water levels in the observation wells respond quickly to changes in stage of Rapid Creek (fig. 46); however, the response attenuates with distance from the creek. Similar responses would be expected in other alluvial areas along Rapid Creek that are not influenced by production wells.

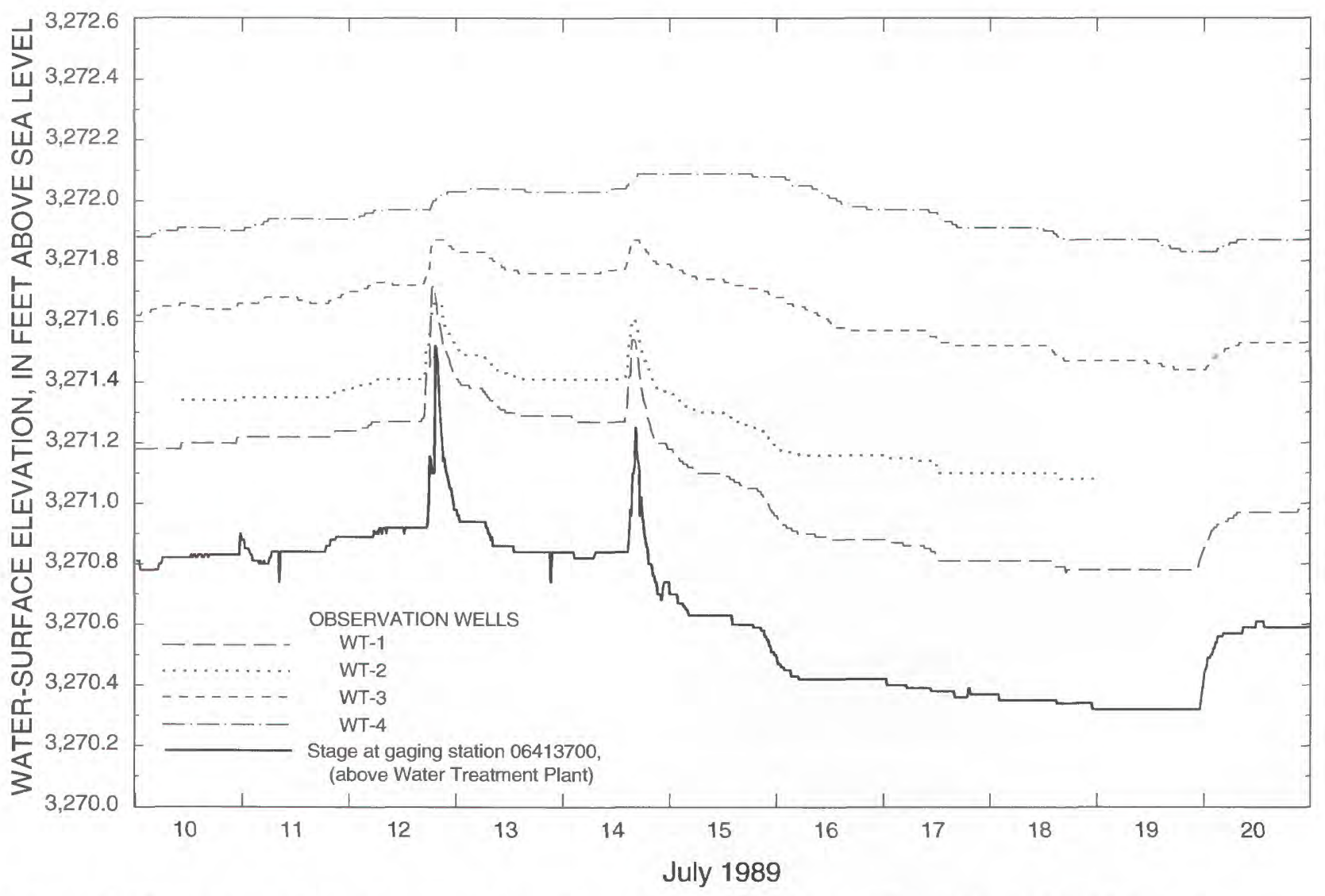

Figure 46. Comparison of alluvial water-surface elevations in alluvial wells and Rapid Creek, July 10 through July 20, 1989. 
Calculated seepage values for individual subreaches provide useful insights on interactions between Rapid Creek and ground water, especially for subreaches without control-volume analyses. Summing individual seepage values for all five subreaches, net seepage for the entire reach was about $-5,930 \mathrm{acre}-\mathrm{ft} / \mathrm{yr}$ (fig. 43). This is equivalent to an average seepage rate of about $8.2 \mathrm{ft}^{3} / \mathrm{s}$ from Rapid Creek to ground water. Although net seepage was negative, the flow of Rapid Creek increased by 960 acre-ft/yr $\left(1.3 \mathrm{ft}^{3} / \mathrm{s}\right)$ during WY 1988-89 (fig. 43) because surface inflows (including the outfall from Cleghorn Springs) exceeded the sum of net seepage and surface withdrawals.

Monthly differences in streamflow from Pactola Reservoir to central Rapid City for WY 1987-90 are presented in table 9. Streamflow within the reach generally increased from October through May; however, decreases were common for June through September. Months when flow decreased (table 9) correspond closely with months of large municipal water production (table 12).

Linear regression was used to examine relations between monthly difference in flow as a function of municipal water production (including golf course irrigation but excluding bedrock wells). Results of regression analyses, using units of cubic feet per second, are presented in table 10. The regression equation is ir the form of:

$$
Y=m X+b
$$

where

$$
\begin{aligned}
Y= & \text { monthly difference in flow of Rapid Creok } \\
& \quad \text { (Pactola Reservoir to Rapid City); } \\
m= & \text { coefficient (slope); } \\
X= & \text { monthly production (including golf courses } \\
& \text { but excluding bedrock wells); and } \\
b= & \text { constant (y intercept). }
\end{aligned}
$$

Regression analyses presented in table 10 are for individual WY 1987, 1988, 1989, and 1990 as we'l as for WY 1988-89 and 1987-90. Results for the various water years and combinations of water years are quite similar. The $\mathrm{r}^{2}$ values range from about 0.61 to 0.89 , which indicates that for these water years, most of the variability in the dependent variable (monthly difference in flow) can be explained by using only monthly production as an independent variable. The regres ${ }^{\circ}$ ion coefficients (slopes) consistently approximate -1 , indicating that streamflow is reduced by an amount similar to municipal production along Rapid Cree' The regression constants (y intercepts) consistently range from about 13 to $24 \mathrm{ft}^{3} / \mathrm{s}$, indicating that without withdrawals, streamflow would increase.

Table 9. Monthly differences in flow of Rapid Creek ${ }^{1}$, water years 1987-90

\begin{tabular}{lcccc}
\hline \multirow{2}{*}{ Month } & \multicolumn{4}{c}{ Monthly difference, In cubic feet per second, by water year } \\
\cline { 2 - 5 } & $\mathbf{1 9 8 7}$ & $\mathbf{1 9 8 8}$ & $\mathbf{1 9 8 9}$ & $\mathbf{1 9 9 0}$ \\
\hline October & 20.8 & 10.1 & -1.1 & 8.1 \\
November & 19.6 & 14.4 & 9.2 & 8.4 \\
December & 19.1 & 10.8 & 9.8 & 6.3 \\
January & 17.4 & 11.7 & 9.4 & 3.8 \\
February & 13.8 & 11.8 & 5.2 & 3.9 \\
March & 9.3 & 13.0 & 10.7 & 7.5 \\
April & 7.9 & 3.3 & 6.2 & 3.9 \\
May & 13.2 & 1.2 & 0.1 & 11.5 \\
June & 3.8 & -21.4 & -8.7 & -1.0 \\
July & -14.0 & -19.1 & -15.1 & -3.0 \\
August & 10.5 & -15.9 & -1.3 & 0.9 \\
September & 12.0 & -17.9 & 5.0 & 0.7 \\
Average for water year & 11.1 & 0.2 & 2.4 & 4.3 \\
\hline
\end{tabular}

${ }^{1}$ Difference computed as flow at downstream station (06414000, at Rapid City) minus upstream station (06411500, below Pactola Dam). 
Table 10. Results of regression analyses for monthly difference in flow of Rapid Creek across study reach as a function of Rapid City municipal water production ${ }^{1}$

\begin{tabular}{lcccc}
\hline & \multicolumn{4}{c}{ Regression information } \\
\cline { 2 - 5 } year & $\begin{array}{c}\text { Coefficient } \\
\text { (slope) }\end{array}$ & $\begin{array}{c}\text { Constant } \\
\text { (y inter- } \\
\text { cept) }\end{array}$ & $\begin{array}{c}\text { Coefficient } \\
\text { of } \\
\text { deter- } \\
\text { mination } \\
\left(\mathbf{r}^{2}\right)\end{array}$ & $\begin{array}{c}\text { Standard } \\
\text { error }\end{array}$ \\
\hline 1987 & -0.90 & 23.5 & 0.786 & 4.6 \\
1988 & -1.10 & 21.2 & .891 & 5.0 \\
1989 & -1.12 & 17.0 & .883 & 2.9 \\
1990 & -.73 & 12.8 & .613 & 2.8 \\
$1988-89$ & -1.03 & 17.9 & .852 & 4.5 \\
$1987-90$ & -.98 & 18.6 & .730 & 5.4 \\
\hline
\end{tabular}

${ }^{1}$ Includes golf course irrigation but excludes bedrock wells.

The regression constants (table 10) actually represent combinations of variables that collectively approximate constants. Previous analyses indicated that interactions with bedrock aquifers collectively result in a net increase in streamflow of about $13.2 \mathrm{ft}^{3} / \mathrm{s}$. This consists of bedrock springflow at the JacksonCleghorn Complex (estimated as $21.6 \mathrm{ft}^{3} / \mathrm{s}$ using control-volume analysis), which is partially offset by streamflow losses to the Madison Limestone and Minnelusa Formation (estimated as $8.4 \mathrm{ft}^{3} / \mathrm{s}$ using hydrologic budgeting). Possible bedrock interactions near Canyon Lake and the Meadowbrook and Girl Scout Galleries are neglected because uncertainties are large and the estimated interactions are small and tend to cancel.

Tributary inflows from Lime Creek and Deadwood Avenue Drain collectively averaged 2,760 acre$\mathrm{ft} / \mathrm{yr}$ (about $4 \mathrm{ft}^{3} / \mathrm{s}$ ) during WY 1988-89 (table 7).

These consistent inflows are large relative to their associated drainage areas, which indicates that most flow originates from bedrock springflow. With these inflows, a net increase of about $17 \mathrm{ft}^{3} / \mathrm{s}$ can be attributed to interactions with bedrock aquifers within the study reach. This is very similar to the regression constants presented in table 10 .

Inflows from other tributaries generally consist of base flow during November through March. Demand is minimal during those months because lawn watering and golf course irrigation seldom occur. Minimal municipal production, excluding bedrock wells, was about 125 to $150 \mathrm{Mgal}$ per month (table 12), or about 6 to $8 \mathrm{ft}^{3} / \mathrm{s}$. Subtracting that value from $17 \mathrm{ft}^{3} / \mathrm{s}$, a "base increase" of about 9 to $11 \mathrm{ft}^{3} / \mathrm{s}$ through the study reach would be expected during periods of minimal tributary inflows and minimal demand. Values near this "base" range were common for the months of November through March (table 9). For that period, most months with substantially larger differences probably had larger tributary inflows (especially in WY 1987), and months with substantially smaller differences may reflect effects of ice formation, which can convert large volumes of water to channel ice and reduce measurement accuracy.

This information can be used in managing releases from Pactola Reservoir during April through October, when demand increases and tributary inflows are likely to be more variable. Assuming no withdrawals and minimal tributary inflows, a net increase of about $17 \mathrm{ft}^{3} / \mathrm{s}$ generally would be expectec between Pactola Reservoir and gaging station 06414000 (at Rapid City). Larger increases would occur if substantial tributary inflows exist, beyond those of Lime Creek and Deadwood Avenue Drain. Increases are reduced by total demands from Rapid Creek withir this reach. In addition to municipal demand, there are withdrawals by residents west of Rapid City, diversions from various ditches, and effects from evapotranspiration. Thus, regression coefficients (slopes) generally are slightly more negative than -1.0 (table 10 ).

In summary, although the hydrology is complex, it also is quite predictable. With estimates of tributary inflows and projected demand, streamflow changes between Pactola Reservoir and Rapid City could be reasonably predicted. Although the methods presented are based on monthly values, daily estimates could be made, but with less accuracy.

\section{SUMMARY AND CONCLUSIONS}

Complex interactions between Rapid Creek and ground water occur between Pactola Reservoir and central Rapid City. Streamflow losses recl arge carbonate aquifers in the Madison Limestone and Minnelusa Formation, in outcrop areas we't of Rapid City. Artesian springflow from these bedrock aquifers occurs in several locations in western Rapid City. Natural interactions are complicated by withdrawals from three municipal infiltration galleries (Jackson Springs, Meadowbrook, and Girl Scout) lc cated in shallow alluvial deposits adjacent to Rapic Creek. 
Rapid City also obtains water from deep wells completed in the Madison and Minnelusa aquifers. Peak demand is supplemented by the municipal Water Treatment Plant, using direct withdrawals from Rapid Creek.

Interactions between ground water and surface water near the three infiltration galleries were studied extensively, with an emphasis on quantifying bedrock springflow using control-volume analyses. Hydrochemical data also were used to identify probable sources of water to each gallery. Hydrologic budgets were developed for WY 1988-89 for five subreaches of Rapid Creek between Pactola Reservoir and central Rapid City. These were two of the driest years on record for the Rapid City area.

The control-volume analysis indicated that combined bedrock springflow from Jackson and Cleghorn Springs averaged 15,600 acre-ft/yr (equivalent to $21.6 \mathrm{ft}^{3} / \mathrm{s}$ ) during WY 1988-89. Production of the Jackson Springs Gallery averaged 4,355 acre-ft/yr $\left(6.0 \mathrm{ft}^{3} / \mathrm{s}\right)$ and measured outfall from the adjacent Cleghorn Springs Fish Hatchery averaged 8,350 acre-ft/yr $\left(11.5 \mathrm{ft}^{3} / \mathrm{s}\right)$. The remainder of the bedrock springflow is contributed to Rapid Creek by seepage through the adjacent alluvium.

Pumping of the Jackson Springs Gallery causes drawdown of about $5 \mathrm{ft}$ below the creek level, in an access manhole immediately adjacent to Rapid Creek, indicating that at least part of the gallery production is induced infiltration from the creek. Drawdown in nearby alluvial observations wells is only about $2 \mathrm{ft}$, with the hydraulic gradient remaining toward Rapid Creek. Water levels in the alluvial aquifer recover within 2 days after pumping is discontinued and flows respond almost immediately in Rapid Creek and the hatchery outfall.

Water from Jackson and Cleghorn Springs is supersaturated with respect to dissolved nitrogen gas and undersaturated with respect to dissolved oxygen, which is characteristic of bedrock aquifers in the area, but different than Rapid Creek. Gas saturation values in water pumped by the Jackson Springs Gallery indicate a minor component of creek water, as do values for radium isotopes. Interpretations of data for stable isotopes of oxygen and hydrogen indicate that about 90 percent of the gallery production generally is from bedrock springflow and about 10 percent is induced infiltration from Rapid Creek. Jackson and Cleghorn Springs are concluded to be a regional discharge point for the Madison aquifer. Springflow consists of isotopically heavier water from the Madison aquifer south of Rapid Creek and a slightly smaller component of isotopically lighter water, which consists of a mix (of unknown proportions) of water from the north and water recharged in the loss zone of Rapid Creek.

The Meadowbrook Gallery produced about 2,100 acre-ft/yr $\left(2.9 \mathrm{ft}^{3} / \mathrm{s}\right)$ during WY 1988-89. Computed bedrock springflow was about 700 acre-ft/yr $\left(1.0 \mathrm{ft}^{3} / \mathrm{s}\right)$; however, the uncertainty associated with this estimate is high. Pumping induces a hydraulic gradient within the alluvial aquifer from Rapid Creek to the gallery. Maximum drawdown is at least $10 \mathrm{ft}$, and alluvial water levels require about 2 weeks for complete recovery. Effects on Rapid Creek are difficult to quantify because of the relatively small pumping rate and the long response time in the large alluvial area that is affected by drawdown. The flow of Leedy Ditch is not measurably affected by gallery pumping.

Dissolved gases and radium isotopes also indicate possible bedrock springflow at Meadowbrock Gallery. Stable isotopes of oxygen and hydrogen shifted from heavier in the winter to lighter in the summer, in response to seasonal changes in isotcpic composition of Rapid Creek. This confirms induced infiltration of creek water; however, the seasonal shift is smaller in the gallery than in the creek, indicat'ng possible bedrock springflow. The combination of evidence indicates that although induced infiltration occurs, bedrock springflow probably is an additional source of water at Meadowbrook Gallery.

The Girl Scout Gallery produced an average of about 880 acre-ft/yr $\left(1.2 \mathrm{ft}^{3} / \mathrm{s}\right)$ during WY 1988-89. Computed bedrock springflow was about 500 acre- $\mathrm{ft} / \mathrm{yr}\left(0.7 \mathrm{ft}^{3} / \mathrm{s}\right)$; however, the uncertaint:" associated with the estimate is high. Pumping induces a hydraulic gradient within the alluvium from both Rapid Creek and Storybook Ditch, toward the gallery, with drawdown extending beyond Rapid Creek to the north. Alluvial water levels recover within 4 to 5 days. Effects on Rapid Creek are difficult to quantify because of the relatively small pumping rate and large streamflow variability that results from upstream influences. The loss rate in Storybook Ditch changed by about $0.5 \mathrm{ft}^{3} / \mathrm{s}$, in response to an average change in punping rate of about $2.6 \mathrm{ft}^{3} / \mathrm{s}$.

Dissolved gases and radium isotopes indic ' possible component of bedrock springflow at Girl Scout Gallery. Stable isotopes of oxygen and hydrogen shifted seasonally, in response to changes in isotopic composition of Rapid Creek. The combination of evidence indicates that production of the Girl Scout 
Gallery consists of induced infiltration from Rapid Creek and Storybook Ditch, mixed with a probable component of bedrock springflow.

Hydrologic budgets were used to quantify ground-water seepage for five subreaches of Rapid Creek. In subreach 1, which extends from Pactola Reservoir to western Rapid City, Rapid Creek loses 6,110 acre-ft/yr (equivalent to an average loss rate of $8.4 \mathrm{ft}^{3} / \mathrm{s}$ ), as recharge to aquifers in the Madison Limestone and Minnelusa Formation. In subreach 2. Rapid Creek gains 2,390 acre- $\mathrm{ft} / \mathrm{yr}\left(3.3 \mathrm{ft}^{3} / \mathrm{s}\right)$ from ground-water seepage, in addition to 8,350 acre-ft/yr $\left(11.5 \mathrm{ft}^{3} / \mathrm{s}\right)$ from the outfall of Cleghorn Springs Fish Hatchery. These inflows are springflow from the Madison aquifer, which also is the primary source of water for the Jackson Springs Gallery. In subreach 3, which includes Canyon Lake, seepage from Rapid Creek is computed as 1.660 acre- $\mathrm{ft} / \mathrm{yr}\left(2.3 \mathrm{ft}^{3} / \mathrm{s}\right)$; however, the standard error of the estimate is large.

Seepage in this reach may occur to alluvial deposits or to outcrops of the Minnekahta Limestone, Opeche Shale, or Minnelusa Formation. In subreach 4. seepage from Rapid Creek is computed as 1,065 acre$\mathrm{ft} / \mathrm{yr}\left(1.5 \mathrm{ft}^{3} / \mathrm{s}\right)$, which results from induced infiltration from pumping of the Meadowbrook and Girl Scout Galleries. In subreach 5, which includes the municipal Water Treatment Plant, interactions with ground water are negligible.

Summing individual seepage values for all five subreaches, net seepage from Rapid Creek to ground water for the entire reach during WY 1988-89 was about 5,930 acre- $\mathrm{ft} / \mathrm{yr}\left(8.2 \mathrm{ft}^{3} / \mathrm{s}\right)$. The flow of Rapid Creek, however, increased by 960 acre-ft/yr $\left(1.3 \mathrm{ft}^{3} / \mathrm{s}\right)$ because surface inflows (including the outfall from Cleghorn Springs) exceeded the sum of net seepage and surface withdrawals. On a monthly basis during WY 1987-90, the change in flow through the entire reach ranged from a decrease of about $21 \mathrm{ft}^{3} / \mathrm{s}$, during months of peak demand, to an increase of about $21 \mathrm{ft}^{3} / \mathrm{s}$.

Linear regression was used to examine relations between monthly difference in streamflow across the entire study reach, as a function of municipal water production (including golf course irrigation but excluding bedrock wells). Results agree well with results of control-volume analyses and hydrologic budgets for various subreaches. Assuming no withdrawals and minimal tributary inflows, a net increase of about $17 \mathrm{ft}^{3} / \mathrm{s}$ generally would result from interactions with bedrock aquifers that occur within the reach. Increases consist primarily of springflow from Jackson and Cleghorn Springs and relatively stable tributary inflows of Lime Creek and the Deadwood Avenue Drain, which probably originate primarily from bedrock springflow. The increases are partially offset by losses to bedrock aquifers west of Rapid City.

Actual streamflow increases are offset by withdrawals from Rapid Creek and its alluvial aquifer. Municipal withdrawals from these sources generally were about 6 to $8 \mathrm{ft}^{3} / \mathrm{s}$ during periods of minimal demand. Although most demand is from municipal production, regression results also reflect $\epsilon$ fects of withdrawals from other sources such as residents west of Rapid City and from several small ditches in Rapid City.

\section{REFERENCES CITED}

Back, William, Hanshaw, B.B., Plummer, L.N., Rahn, P.H., Rightmire, C.T., and Rubin, Meyer, 1983, Process and rate of dedolomitization: Mass transfer and ${ }^{14} \mathrm{C}$ dating in a regional carbonate aquifer: Geological Society of America Bulletin, v. 94, p. 1415-1429.

Broecker, W.S., 1965, An application of natural radon to problems in ocean circulation, in Symposium on Diffusion in Oceans and Fresh Waters: Lamont Geological Observatory, Palesades, N.Y., p. 116-145.

Brown, D.L., Blankennagel, R.K., MacCary, L.M., and Peterson, J.A., 1982, Correlation of paleo tructure and sediment deposition in the Madison Limestone and associated rocks in parts of Montana, North Dakota, South Dakota, Wyoming, and Nebraska: U.S. Geological Survey Open-File Report 82-096, 71 p.

Bureau of Reclamation, 1943, Contract between the United States, Rapid City, South Dakota, and the Rapid Valley Water Conservancy District: Billings, Mont., $30 \mathrm{p}$. 1952a, Contract for purchase of water between the United States of America and the City of Rapid City, South Dakota: Billings, Mont., $6 \mathrm{p}$.

1952b, Definite plan report for Rapid Valley Unit,

Volume 1, Part 1: Huron, S. Dak., 54 p.

1961, Contract for the purchase of wate- between the United States of America and the Rapid Valley Water Conservancy District: Billings, Mont., 6 p. 1985a, Rapid City water supply study: Billings, Mont., Preliminary findings report, 85 p.

1985b, Reservoir capacity allocation for Deerfield Dam and Reservoir: Denver, Colo., 1 p.

1988, Reservoir capacity allocation for Pactola Dam and Reservoir: Denver, Colo., 1 p.

1989, Standing operating procedures, Factola Dam and Reservoir: Billings, Mont., 118 p.

1990, Annual summary of Deerfield and Pactola Reservoir operations: Billings, Mont., 18 p. 
Burkham, D.E., and Dawdy, D. R., 1970, Error analysis of streamflow data for an alluvial stream: U.S. Geological Survey Professional Paper 655-C, 13 p.

Cattermole, J.M., 1969, Geologic map of the Rapid City west quadrangle, Pennington County, South Dakota: U.S. Geological Survey Geologic Quadrangle Map GQ-828, scale 1:24,000.

1972, Geologic map of the Rapid City east quadrangle, Pennington County, South Dakota: U.S. Geological Survey Geologic Quadrangle Map GQ-986, scale 1:24,000.

Craig, H., 1961, Isotopic variations in meteoric waters: Science, v. 13, p. 1702-1703.

Darton, N.H., 1909, Geology and water resources of the northern portion of the Black Hills and adjoining regions in South Dakota and Wyoming: U.S. Geological Survey Professional Paper 65, 105 p.

Davis, A.D., 1991, Determination of ground-water flow conditions and extent of petroleum contamination in Rapid Creek alluvial aquifer at Rapid City, South Dakota: Final technical report submitted to South Dakota Department of Environment and Natural Resources, $140 \mathrm{p}$.

Delzer, G.C., 1993, Water quality and nutrient survey for those portions of Rapid Creek from below Pactola Reservoir to below Canyon Lake including Canyon Lake and Cleghorn Springs Fish Hatchery in Rapid City, South Dakota: Rapid City, South Dakota School of Mines and Technology, unpublished M.S. thesis, $157 \mathrm{p}$.

DeWitt, Ed, Redden, J.A., Buscher, David, and Wilson, A.B., 1989, Geologic map of the Black Hills area, South Dakota and Wyoming: U.S. Geological Survey Misce1laneous Investigations Series Map I-1910, scale 1:250,000, 1 sheet.

Drever, J.I., 1988, The geochemistry of natural waters (2d ed): Englewood Cliffs, N.J., Prentice Hall, 437 p.

Driscoll, D.G., 1987, Water yield and streamflow characteristics of Rapid Creek above Rapid City, South Dakota: Rapid City, South Dakota School of Mines and Technology, unpublished M.S. thesis, $116 \mathrm{p}$.

Driscoll, D.G., Bradford, W.L., and Neitzert, K.M., 1996. Selected hydrologic data, through water year 1994, Black Hills Hydrology Study, South Dakota: U.S. Geological Survey Open-File Report 96-399, 162 p.

Driscoll, D.G., and Zogorski, J.S., 1990, Basin characteristics, history of stream gaging, and statistical summary of selected streamflow records for the Rapid Creek Basin, western South Dakota: U.S. Geological Survey Open-File Report 90-120, 147 p.

Foster, A.D., 1985, Municipal water systems, Rapid City, South Dakota: Rapid City, FMG, Inc., 114 p.

Freeman, J.E., and Komor, S.C., 1991, Selected waterquality data for Rapid Creek Basin, southwestern South Dakota, 1946-90: U.S. Geological Survey Open-File Report 91-249, 194 p.
Gat, J.R., and Gonfiantini, R., eds, 1981, Stable isotope hydrology: Deuterium and oxygen-18 in the water cycle: International Atomic Energy Agency Technical Reports Series No. 210, 340 p.

Geibel, N.M., 1991, Ground-water flow conditions in the Rapid Creek alluvial aquifer at Rapid City, South Dakota: Rapid City, South Dakota School of Mines and Technology, unpublished M.S. thesis, $82 \mathrm{p}$.

Greene, E.A., 1992, Use of seismic refraction to determine the depth to water and saturated thickness of an all "vial aquifer along Rapid Creek, Rapid City, South Dalota, in National Ground Water Association 7th Annual Outdoor Action Conference, May 25-27, Proceedings: Las Vegas, Nevada, p. 339-348.

1993, Hydraulic properties of the Madison aquifer system in the western Rapid City area, South Dakota: U.S. Geological Survey Water-Resources Investigations Report 93-4008, 56 p.

1997, Tracing recharge from sinking streams over spatial dimensions of kilometers in a karst aquifer: Ground Water, v. 35, no. 5, p. 898-904.

Heaton, T.E., and Vogel, J.C., 1981, Excess air in groundwater: Journal of Hydrology, v. 50, p. 201-216.

Hines, G.K., 1991, Ground-water and surface-water in ${ }^{+}$-raction in a reach of Rapid Creek near Rapid City, $\mathbf{S}$ outh Dakota: Rapid City, South Dakota School of Mines and Technology, unpublished M.S. thesis, $86 \mathrm{p}$.

Iman, R.L., and Conover, W.J., 1983, A modern approa $h$ to statistics: New York, John Wiley \& Sons, 497 p.

Jorgenson, M.J., 1990, Water quality reconnaissance of the Rapid Creek alluvial aquifer in the Rapid City area, South Dakota: Rapid City, South Dakota School of Mines and Technology, unpublished M.S. thesis, 98 p.

Mathieu, G.G., 1988, Systems for measurement of 222Rn at low levels in natural waters: Health Physics 55, p. 989-992.

Michel, J., and Moore, W.S., 1980, 228Ra and 226Ra content of groundwaters in Fall Line aquifers: Health Physics 38, p. 663-671.

Michel, J., Moore, W.S., and King, P.T., 1981, Gamma ray spectrometry for determination of radium-228 and radium-226 in natural waters: Analytical Chemistry 53, p. 1885-1889.

Orr, H.K., 1959, Precipitation and streamflow in the Black Hills: Rocky Mountain Forest and Range Experiment Station Paper No. 44, 25 p.

Packard, B.L., 1988, Computer model for the determination of a hydrologic budget for a reach of Rapid Creek and a study of Leedy Ditch, Rapid City, South Dakota: Papid City, South Dakota School of Mines and Technology, unpublished M.S. thesis, $102 \mathrm{p}$.

Peter, K.D., 1985, Availability and quality of water from the bedrock aquifers in the Rapid City area, South Dakota: U.S. Geological Survey Water-Resources Investigations Report 85-4022, 34 p. 
Peter, K.D., Mills, K.R., and Loskot, C.L., 1991, Map showing geologic structure and altitude of the top of the Minnelusa Formation and orientation of mapped cave passages in the Madison Limestone, southern Black Hills, South Dakota: U.S. Geological Survey WaterResources Investigations Report 86-4167, 1 sheet.

Rahn, P.H., and Gries, J.P., 1973, Large springs in the Black Hills, South Dakota and Wyoming: South Dakota Geological Survey Report of Investigations 107, 46 p.

Rapid City Public Works Department, 1987-90, Public works year end reports: Rapid City, S. Dak. (issued annually).

Robinson, C.S., Mapel, W.J., and Bergendahl, M.H., 1964, Stratigraphy and structure of the northern and western flanks of the Black Hills, Wyoming, Montana, and South Dakota: U.S. Geological Survey Professional Paper 404, 134 p.

Schwarz, F.K., Hughes, L.A., Hansen, E.M., Petersen, M.S., and Kelly, D.B., 1975, The Black Hills-Rapid City flood of June 9-10, 1972-A description of the storm and flood: U.S. Geological Survey Professional Paper $877,45 \mathrm{p}$.

Soedjatmiko, Bogie, 1990, Application of a seismic survey for determining thickness of Rapid Creek alluvium, Rapid City, South Dakota: Rapid City, South Dakota School of Mines and Technology, unpublished M.S. thesis, $104 \mathrm{p}$.

Stetler, L.D., 1989, Evaluation of new infiltration gallery sites to augment Rapid City's water supply: Rapid City, South Dakota School of Mines and Technology, unpublished M.S. thesis, 162 p.
Stewart, W.C., Houtcooper, Wayne, and Delange, Keith, 1989, Canyon Lake and Rapid Creek diagnostic feasibility study: South Dakota Department of Water and Natural Resources, Water Resources Management Division, $52 \mathrm{p}$.

Streeter, V.L., and Wylie, E.B., 1979, Fluid me hanics (7th ed): New York, McGraw-Hill, 562 p.

U.S. Department of Commerce, 1987-90, Climatological data for South Dakota: Asheville, N.C. (issued annually).

U.S. Geological Survey, 1988-91, Water resou "ces data for South Dakota, water years 1987-90: U.S. Geological Survey Water Data Reports SD-87-1 to SD-90-1 (published annually).

U.S. Water and Power Resources Service, 1981, Project data: Denver, Colo., 1.463 p.

Weitkamp, D.E., and Katz, M., 1980, A review of dissolved gas supersaturation literature: Transactions of the American Fishery Society, v. 109, p. 659-702.

Williams, J.M., 1988, The origin and occurrence of dissolved nitrogen and oxygen in natural waters of the Black Hills area, South Dakota: Rapid City, South Dakota School of Mines and Technology, unpublished M.S. thesis, $85 \mathrm{p}$.

Williamson, J.E., Goldstein, R.M., and Porter, S.D., 1996, Selected trace metals in water, sediment, plants, and fish in Rapid Creek, Rapid City, South D-kota, 1993-94: U.S. Geological Survey Water-Resources Investigations Report 96-4276, $30 \mathrm{p}$.

Zogorski, J.S., Zogorski, E.M., and McKallip, T.E., 1990, Sources and summaries of water-quality information for the Rapid Creek Basin, western South Dakota: U.S. Geological Survey Open-File Report 90-1 15, 35 p. 


\section{SUPPLEMENTAL INFORMATION}


Table 11. Chronology of historical events relevant to water development in the Rapid Creek Basin

[ft, feet: gal/min, gallons per minute; Mgal/d, million gallons per day; $\mathrm{ft}^{3} / \mathrm{s}$, cubic feet per second]

\begin{tabular}{cc} 
Year & \multicolumn{1}{c}{ Event } \\
\hline 1876 & Rapid City founded by John R. Brennan (Feb. 25). \\
1877 & $\begin{array}{l}\text { First ranch established in Rapid Valley by Tom Taylor. Priority date of first water right for municipal use issued to } \\
\text { Cleghorn Springs Water Users Association. Priority date of first water right for irrigation use on Leedy Ditch to }\end{array}$ \\
& $\begin{array}{l}\text { J. Leedy (South Dakota Department of Environment and Natural Resources, Division of Water Rights, written } \\
\text { commun., 1990). }\end{array}$
\end{tabular}

1878 First recorded flood on Rapid Creek (July 16); one life lost (Rapid City Journal).

1885 City purchases land and water right from C. Leedy at City Springs. These springs were referred to as Lime, Limestone, Limecreek, or Leedy Springs in various accounts (Earl Grant, local historian, written commun., 1953; Stetler, 1989).

1886 First municipal water flowed through flume from City Springs to reservoir in Rapid City (Earl Grant, Incal historian. written commun., 1953; Stetler, 1989).

1892 Additional development of City Springs (Stetler, 1989).

1906 Cleghorn Springs developed by Federal government for non-municipal purposes (Earl Grant, local historian, written commun., 1953; Stetler, 1989).

1910 Water meters installed in city (Stetler, 1989).

1912 Well dug at Tittle Springs in Dark Canyon at same elevation as City Springs (Earl Grant, local historian, written commun., 1953; Stetler, 1989).

1930 Development of additional spring source (Merrill Springs) at City Springs (Leo A. Daly Company, w-itten commun., 1955).

1935 City begins drilling deep wells because of drought and low flows at City Springs. Well RC-1 drilled to $1,460 \mathrm{ft}$, plugged back to $880 \mathrm{ft}$, and produced $640 \mathrm{gal} / \mathrm{min}$ (Stetler, 1989).

1936 Well RC-2 drilled just southeast of Canyon Lake to top of Madison Limestone. RC-2 produced 150 to $400 \mathrm{gal} / \mathrm{min}$ (Stetler, 1989) but was abandoned because of problems with caving in (Earl Grant, local historian, written commun., 1953). Well RC-3 drilled to $957 \mathrm{ft}$ and produced $670 \mathrm{gal} / \mathrm{min}$ from the Minnelusa aquifer (S‘tler, 1989).

1939 Well RC-4 drilled to $1,070 \mathrm{ft}$ into the Minnelusa aquifer and produced $700 \mathrm{gal} / \mathrm{min}$ (Stetler, 1989).

1940 Approximate date of abandonment of Dark Canyon well (Tittle Springs) (Stetler, 1989).

1941 Well drilled north of current water treatment plant to $1,415 \mathrm{ft}$. Well produced only $100 \mathrm{gal} / \mathrm{min}$ and was abandoned (Stetler, 1989).

1942 Approximate date of construction of Jackson Springs Gallery (Leo A. Daly Company, written commın., 1955; Stetler, 1989).

1945 Deerfield Dam begins to fill with water.

1952 Meadowbrook Gallery constructed (Leo A. Daly Company, written commun., 1955; Stetler, 1989).

1955 Meadowbrook Gallery expanded to present capacity (4 Mgal/d) (Foster, 1985; Stetler, 1989). Walpole well utilized as municipal source (Rapid City Water Department, annual records).

1956 Pactola Reservoir begins to fill with water.

1960 Girl Scout Gallery constructed (2.0 Mgal/d capacity). Water Treatment Plant constructed (16.0 Mgal/d capacity, 21.5 Mgal/d peak capacity) (Foster, 1985; Stetler, 1989).

1967 Well RC-3 removed from service (Rapid City Water Department, annual records).

1970 Well RC-1 removed from municipal service but retained for park irrigation (Stetler, 1989). Well RC-4 and Walpole well removed from service (Rapid City Water Department, annual records). 
Table 11. Chronology of historical events relevant to water development in the Rapid Creek Basin-Continued

[ft, feet; gal/min, gallons per minute: Mgal/d, million gallons per day; $\mathrm{ft}^{3} / \mathrm{s}$, cubic feet per second]

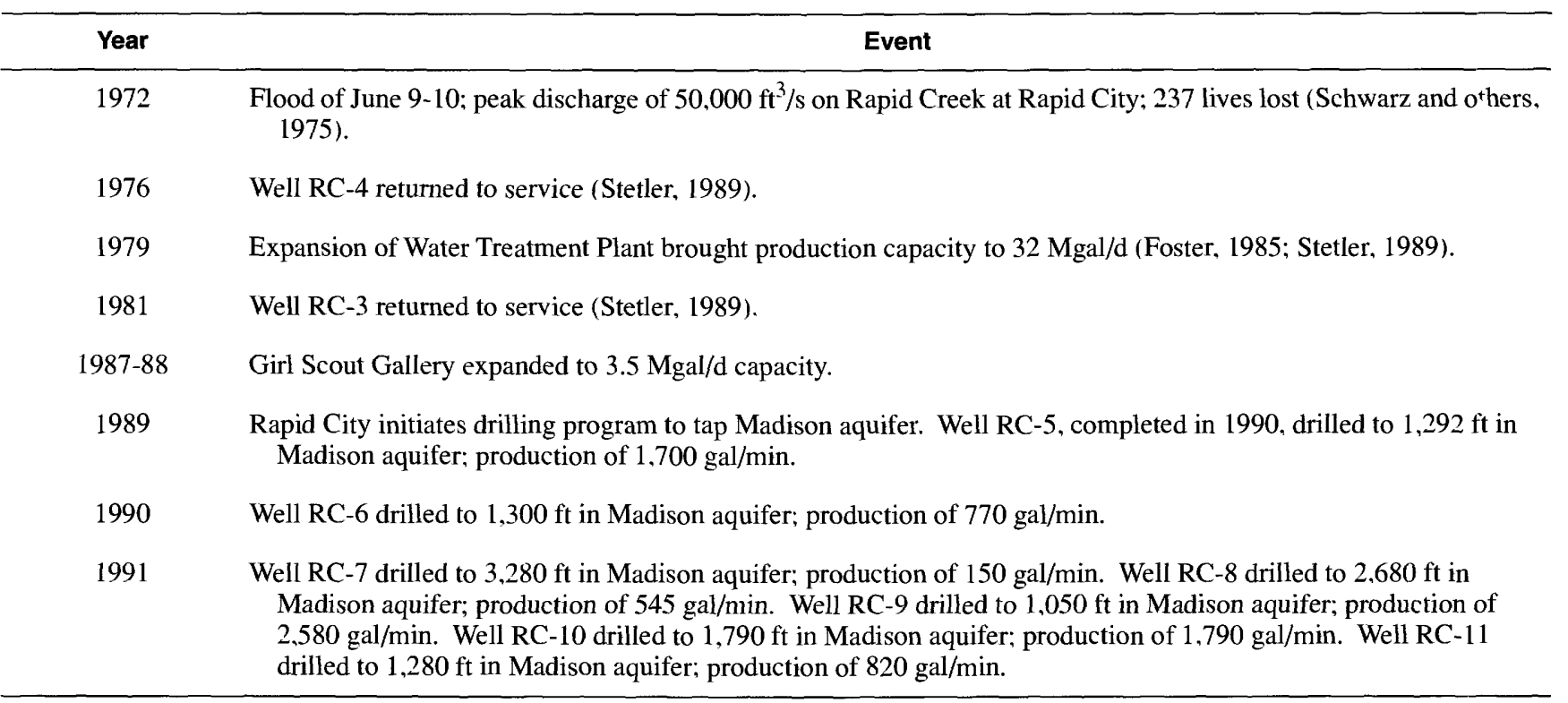




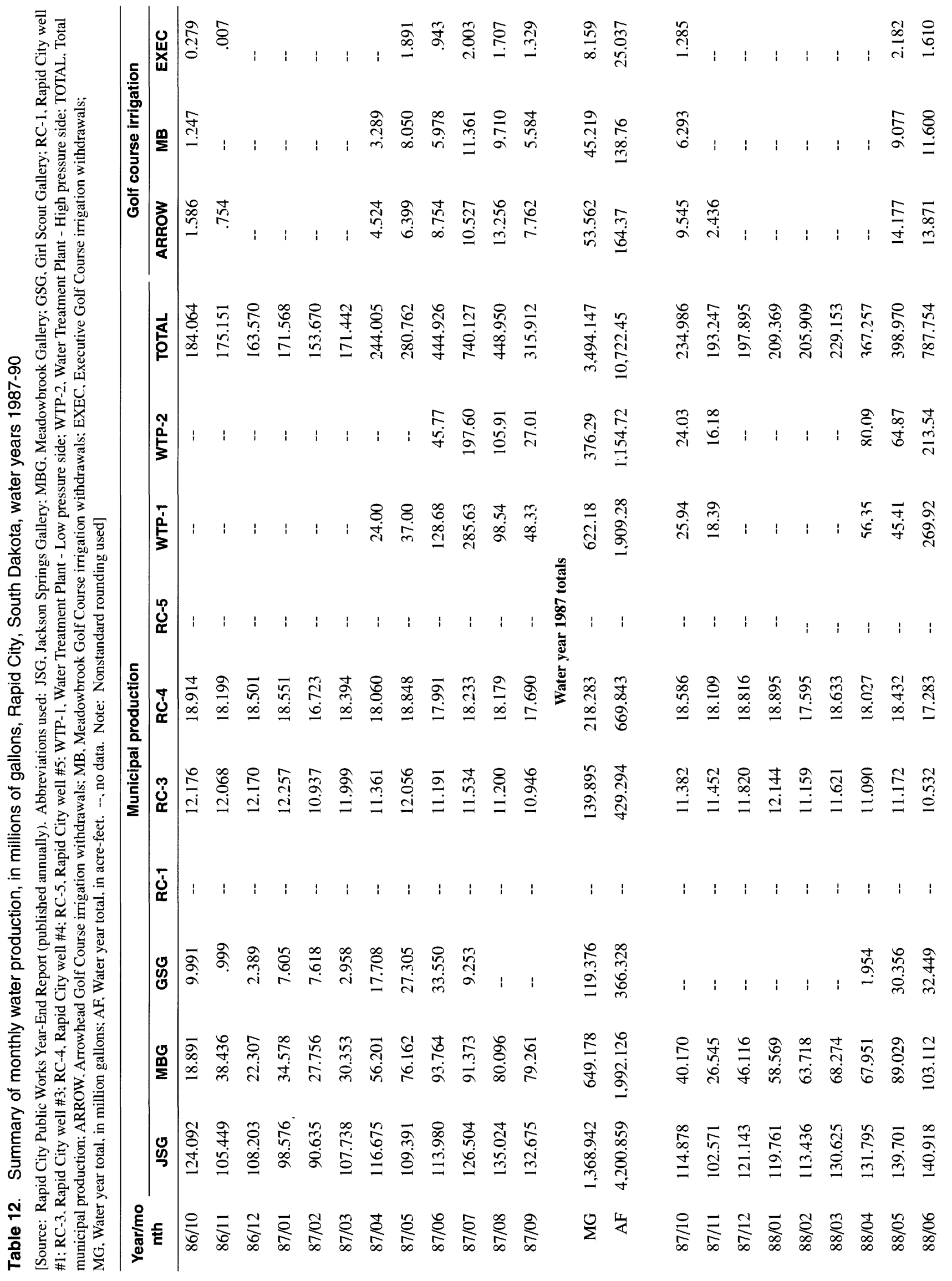




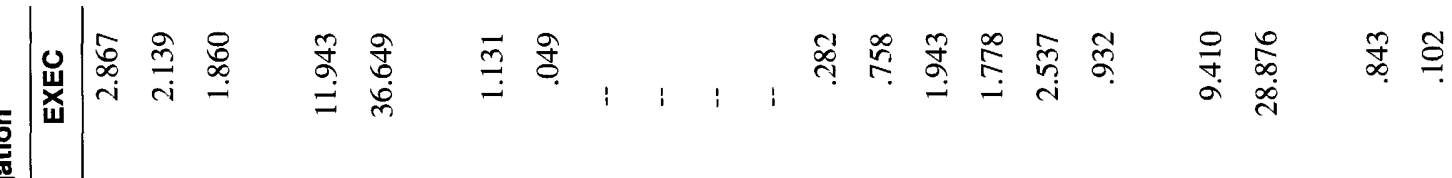

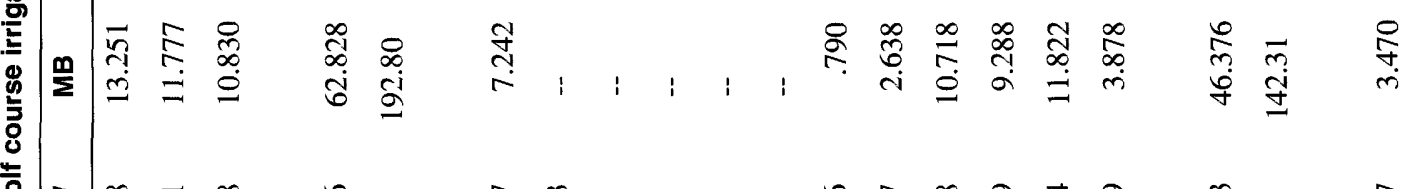

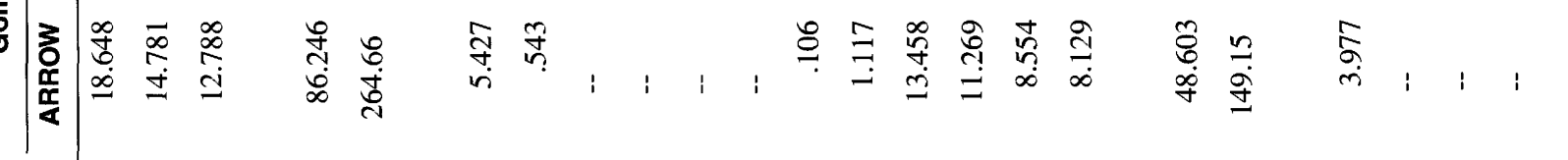

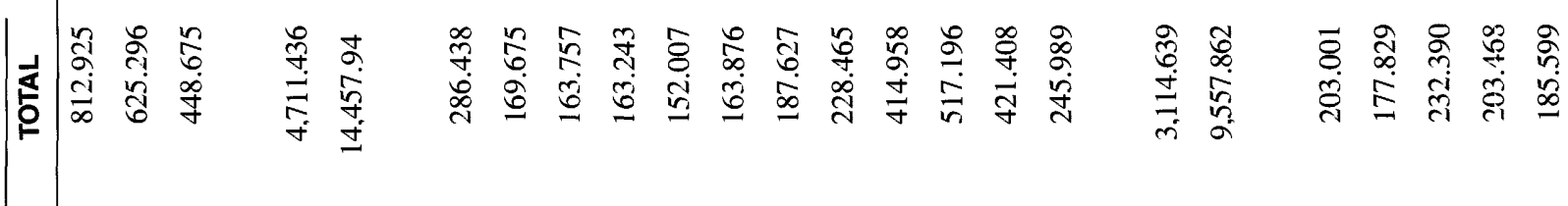

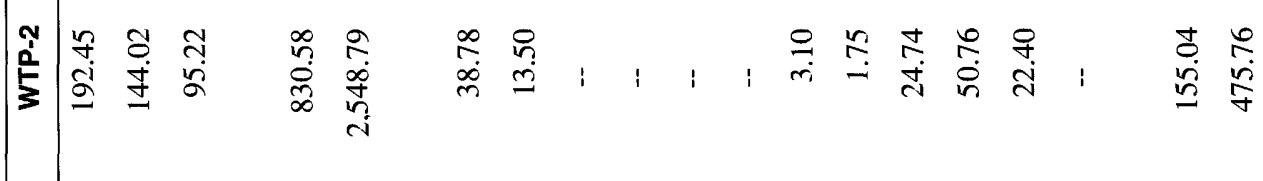

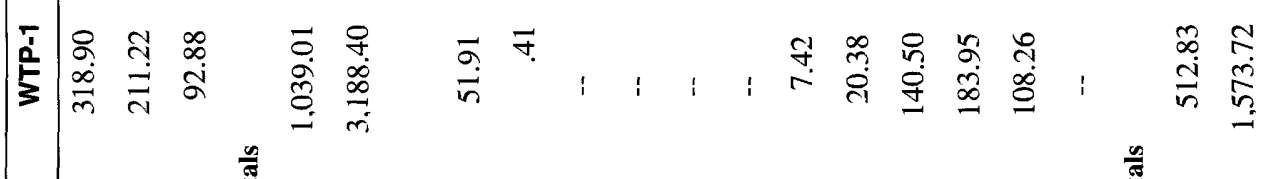

\section{高}

嘉

言

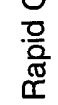

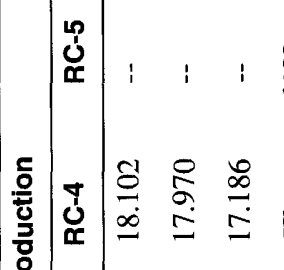

需

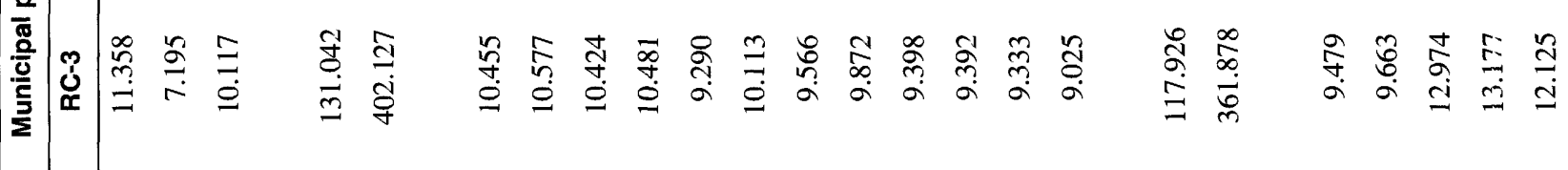

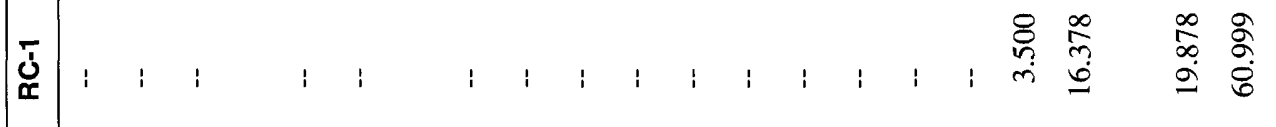

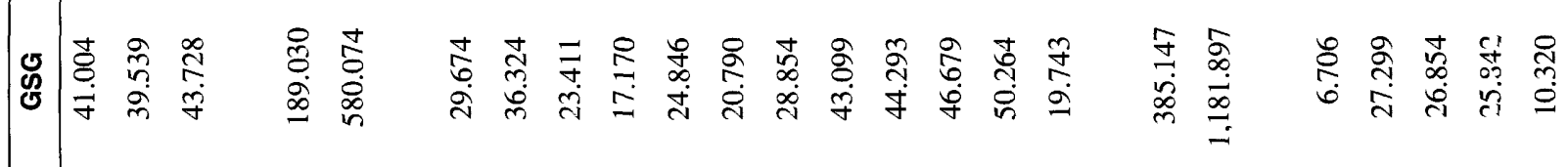

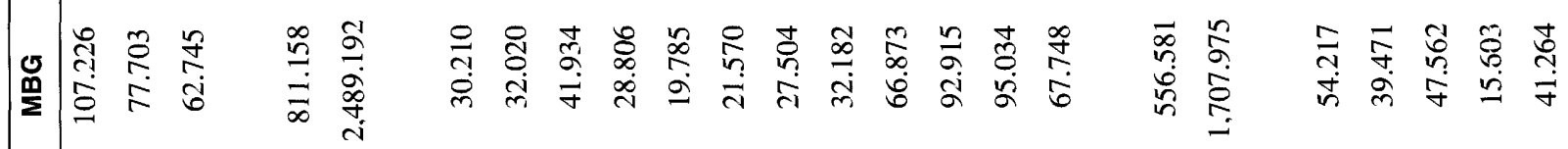

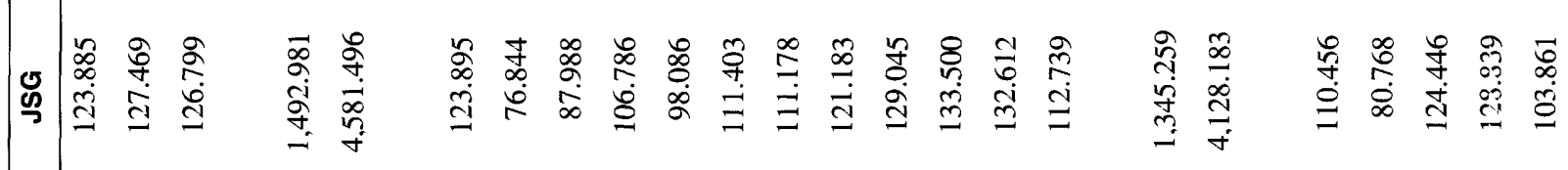
光 


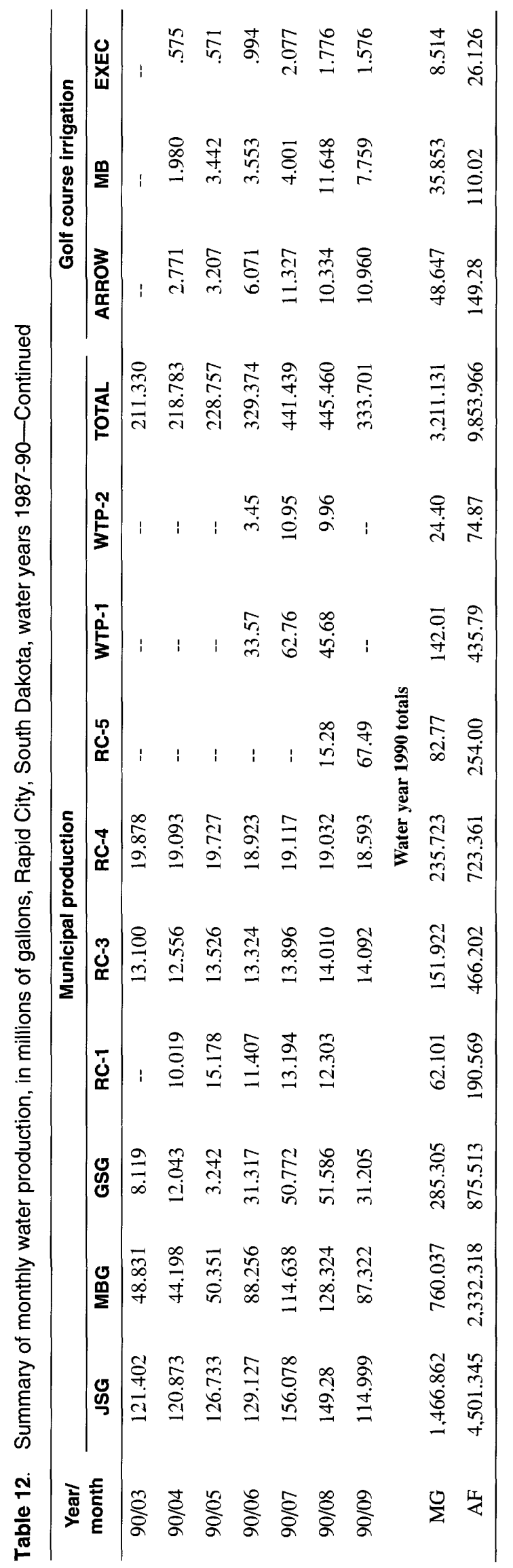


Table 13. Water-level data for observation-well network at Jackson-Cleghorn Complex [--, no data]

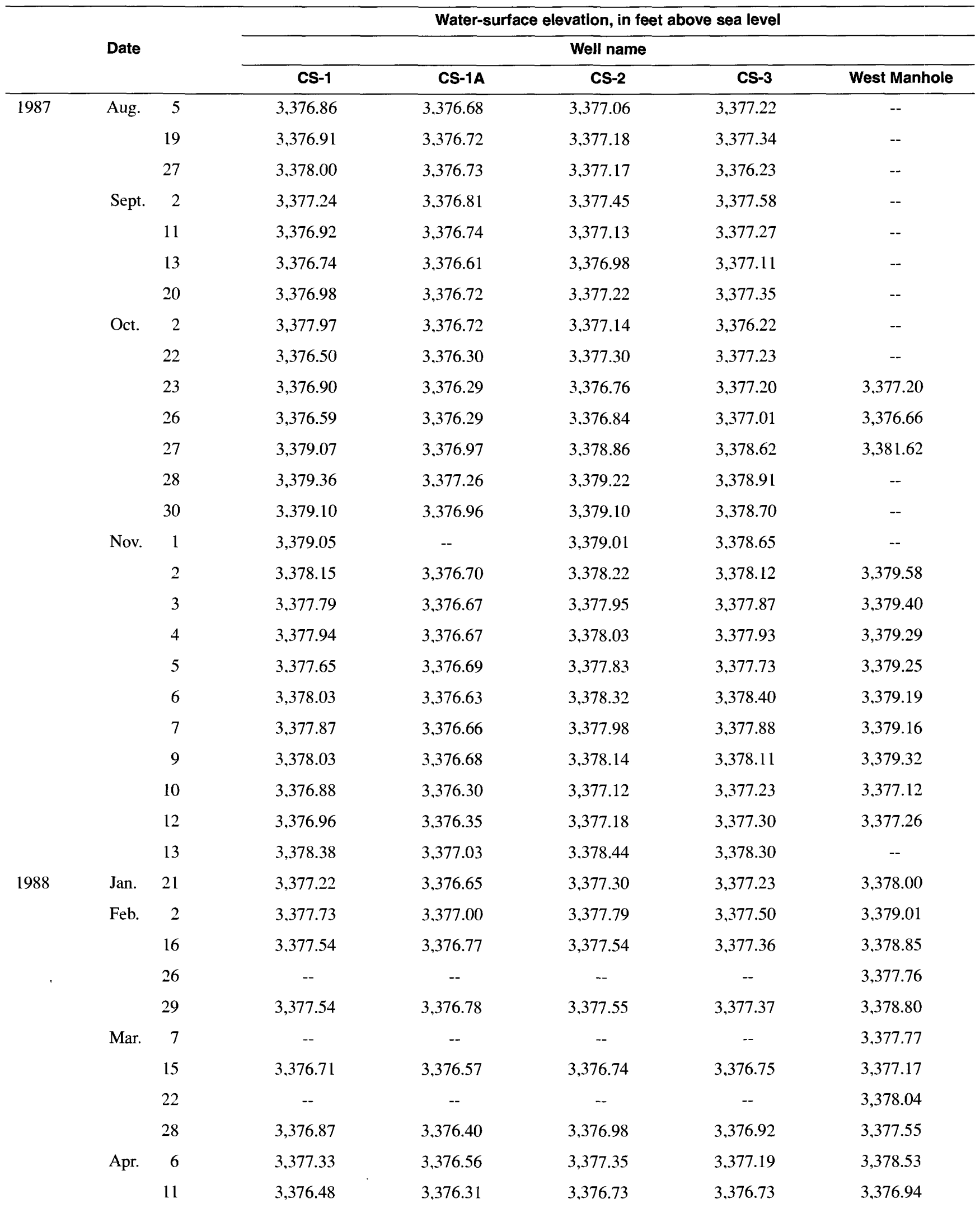


Table 13. Water-level data for observation-well network at Jackson-Cleghorn Complex-Continued [--, no data]

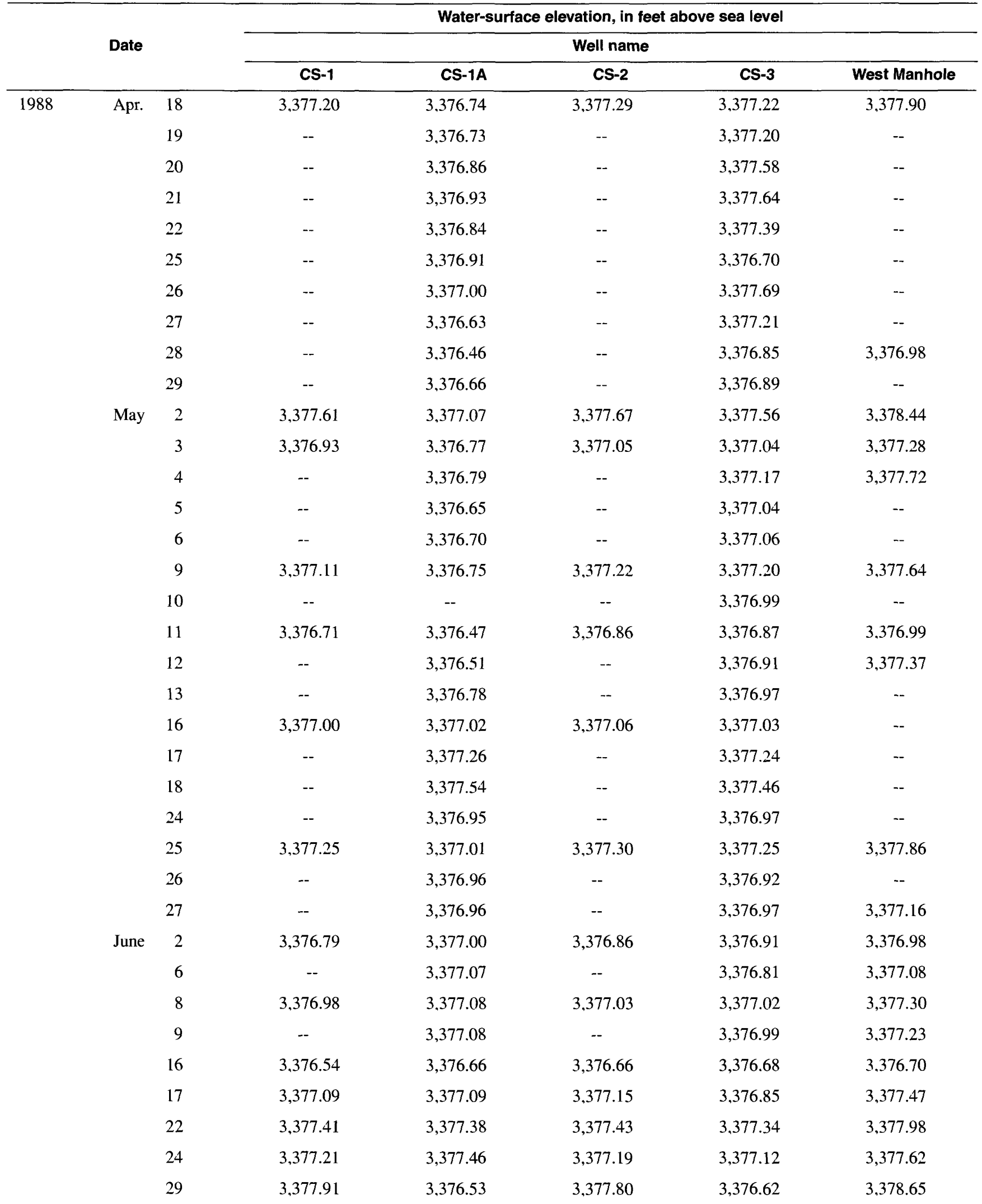


Table 13. Water-level data for observation-well network at Jackson-Cleghorn Complex-Continued [--, no data]

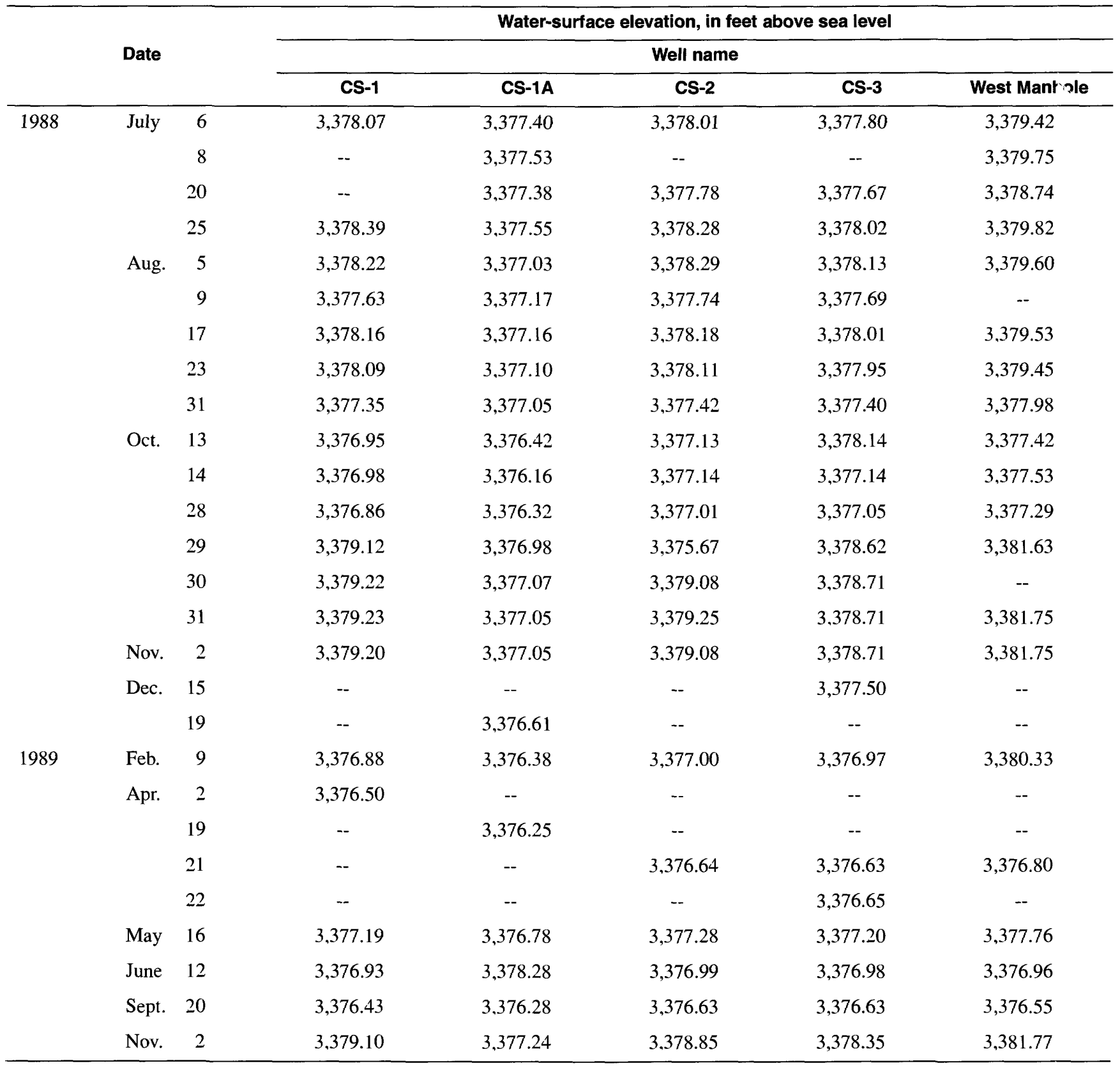




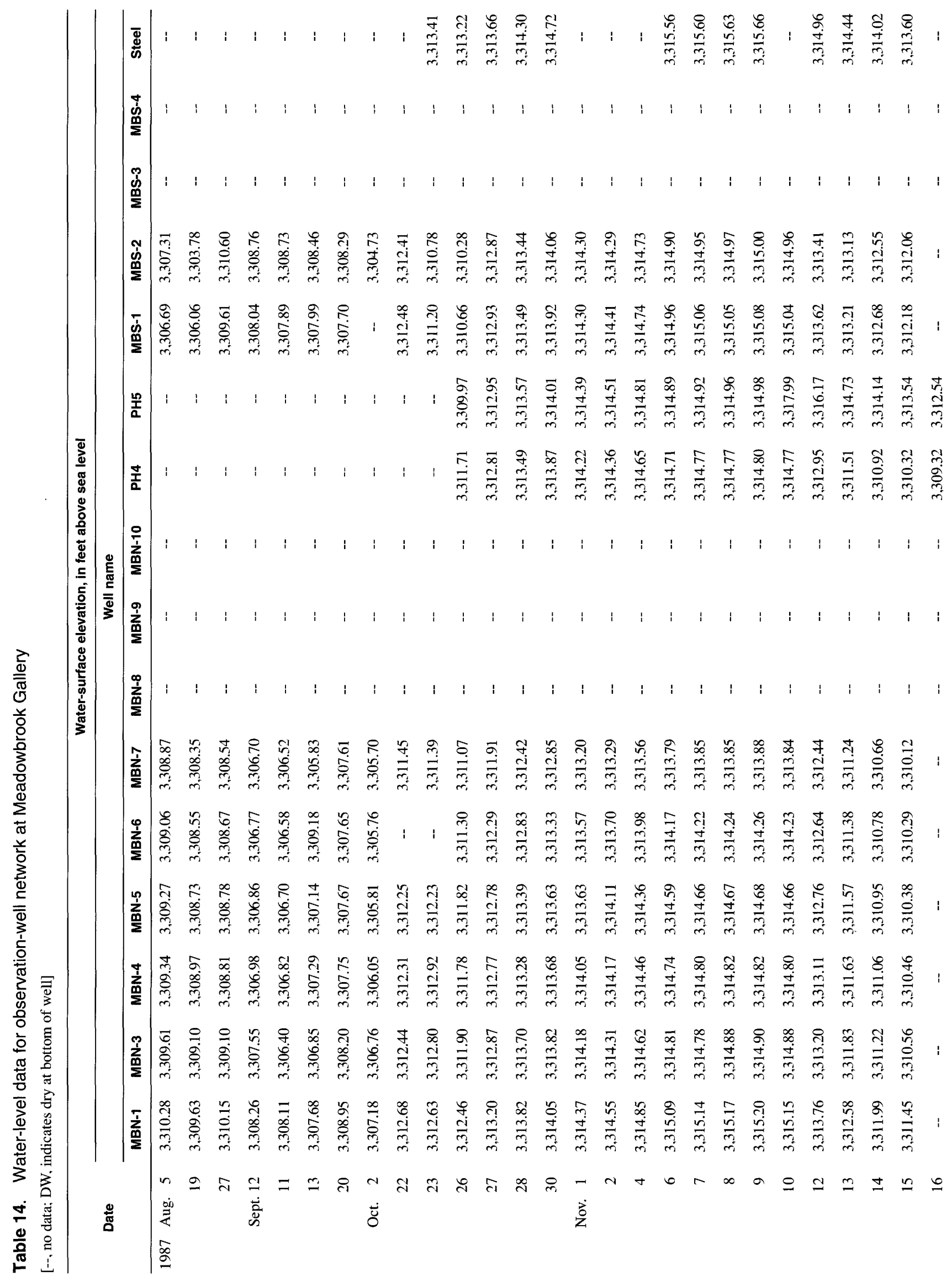




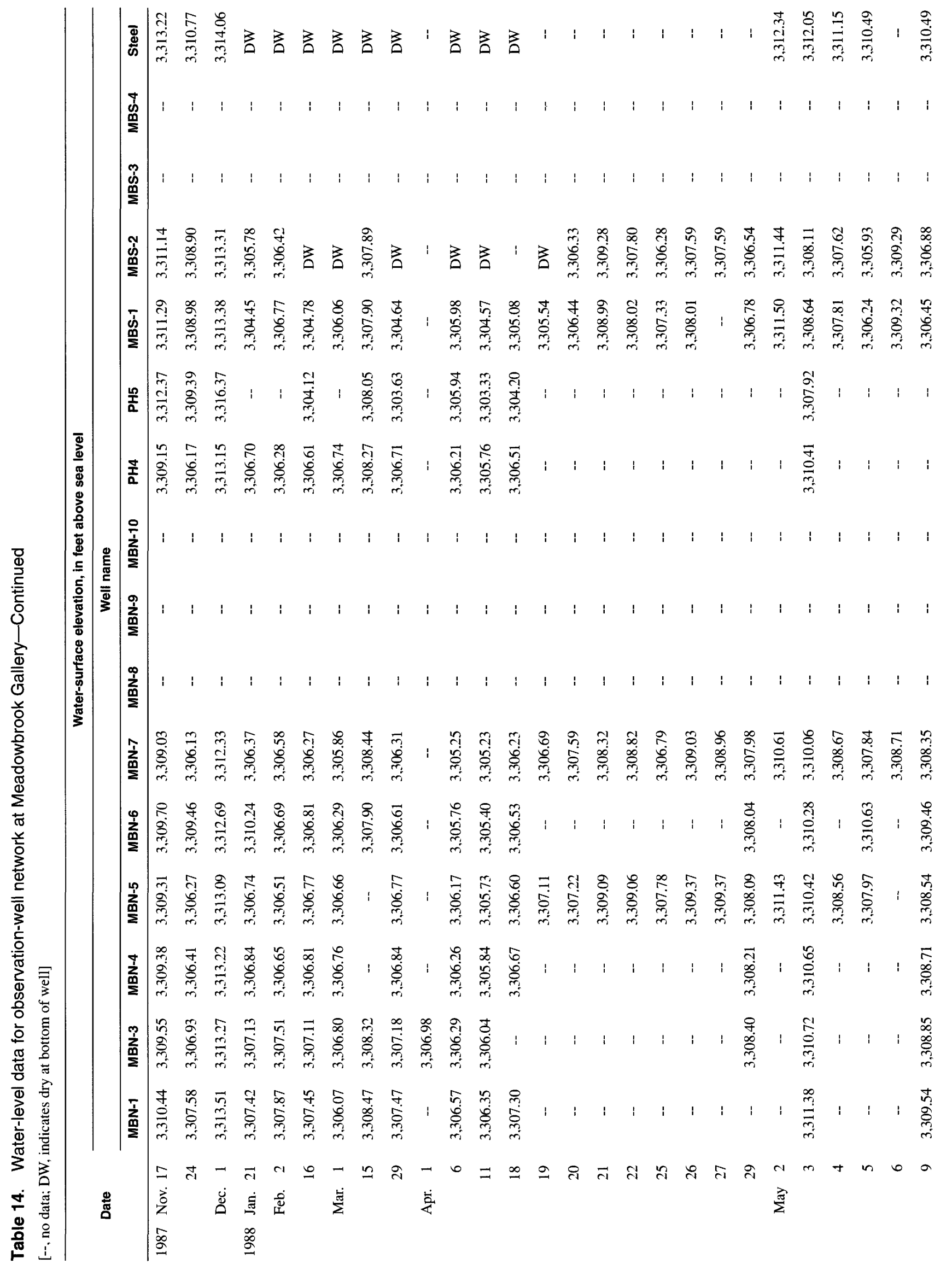




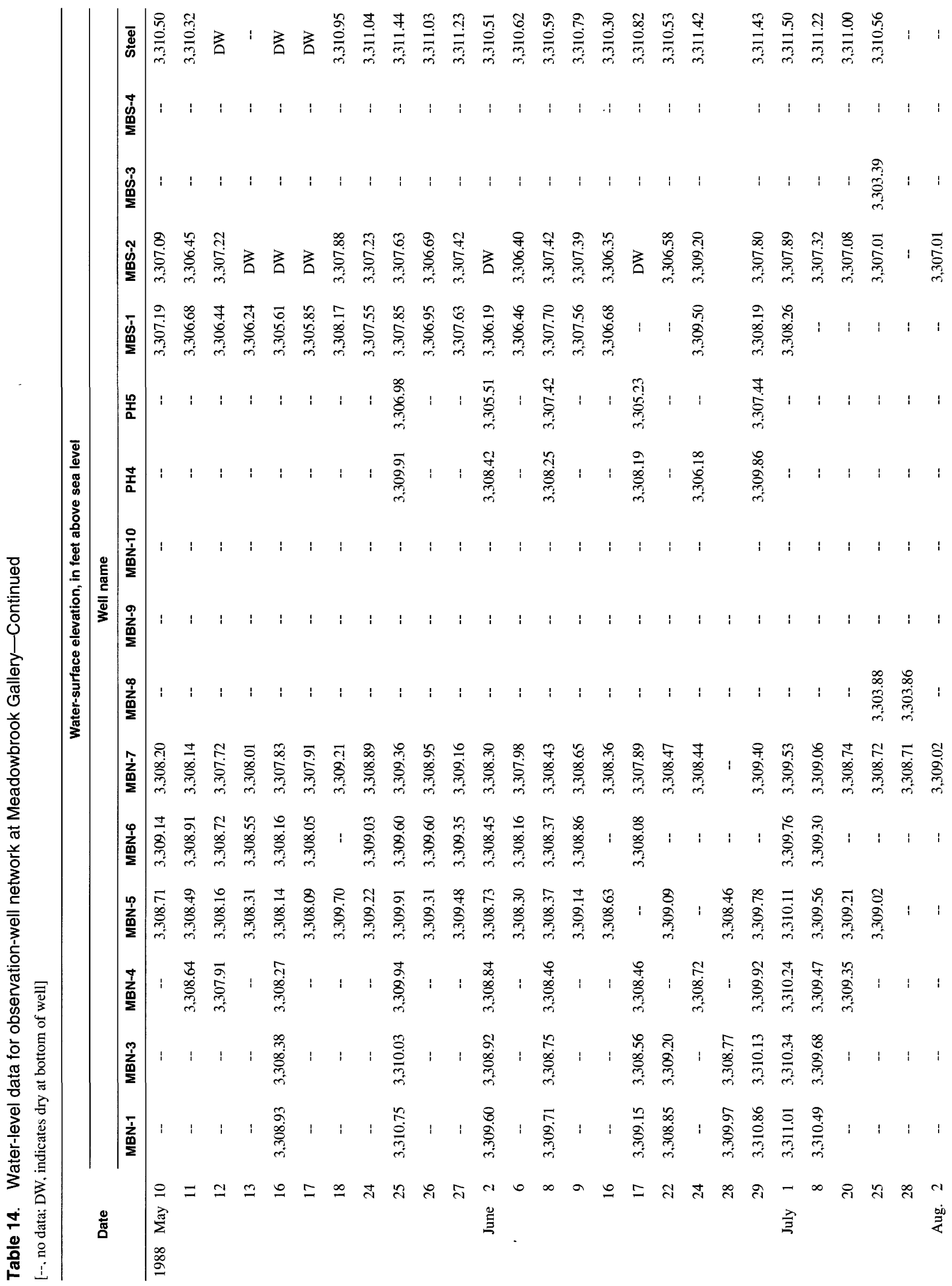




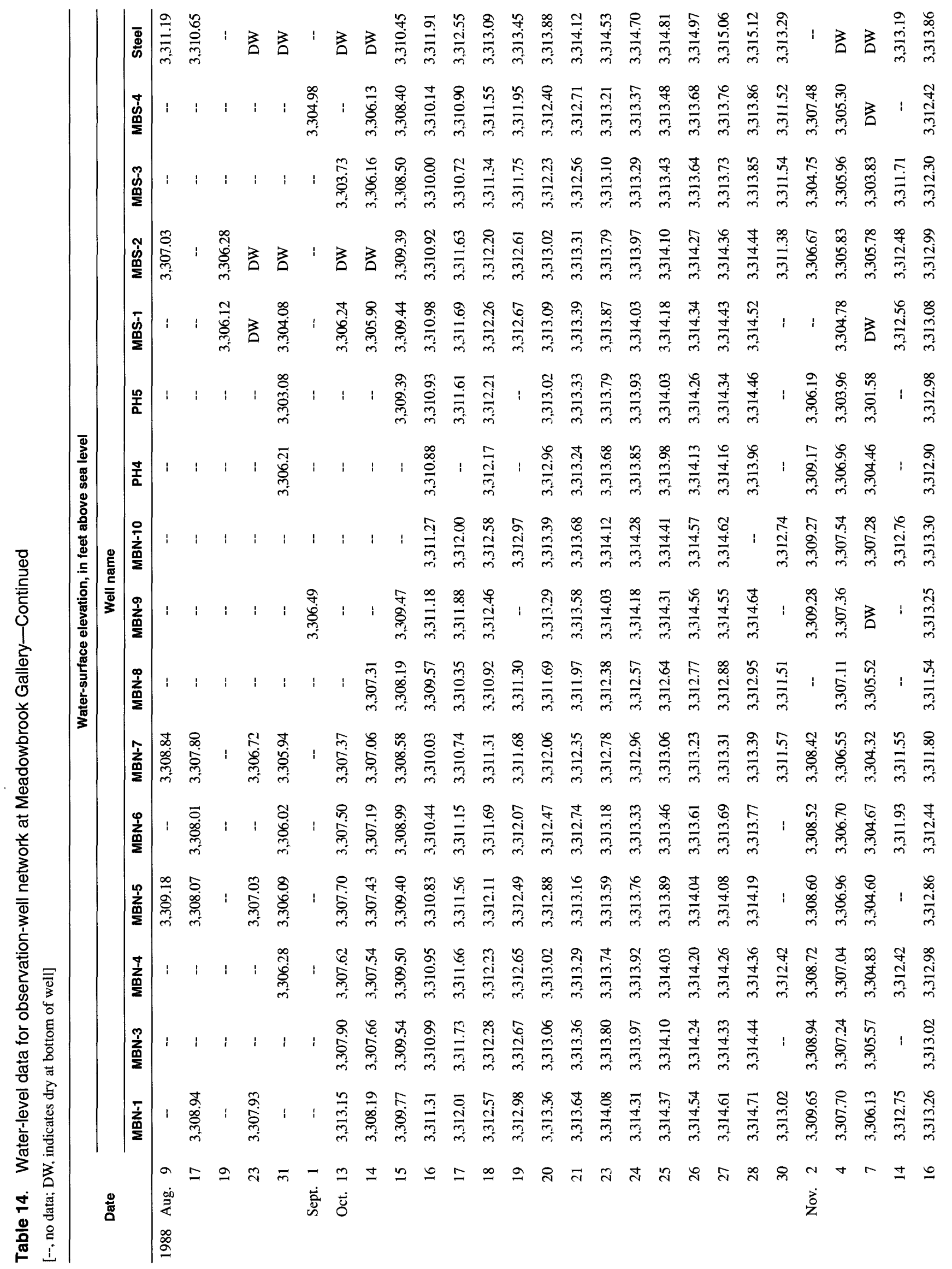




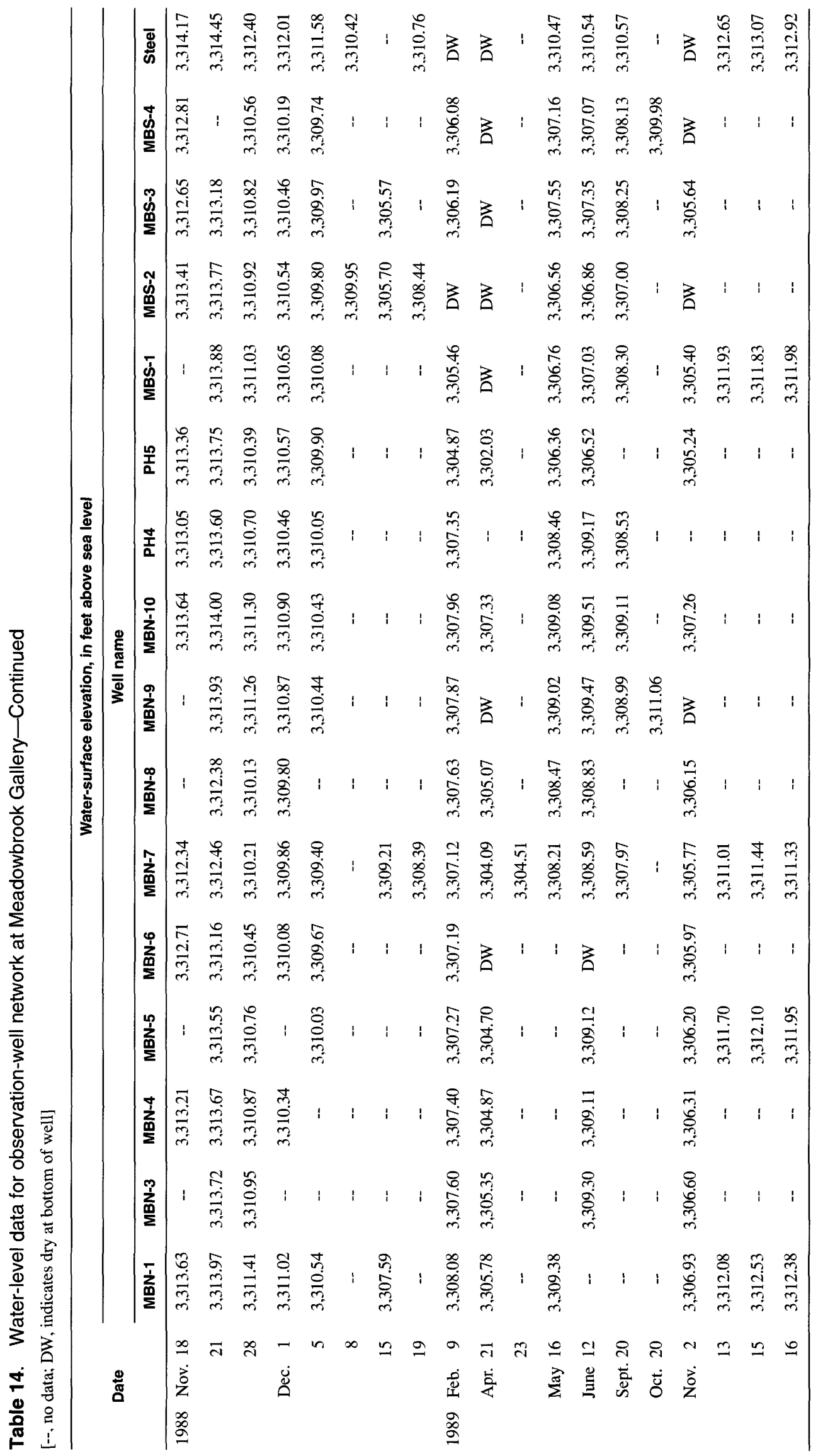


Table 15. Water-level data for observation-well network at Girl Scout Gallery

$[--$, no data $]$

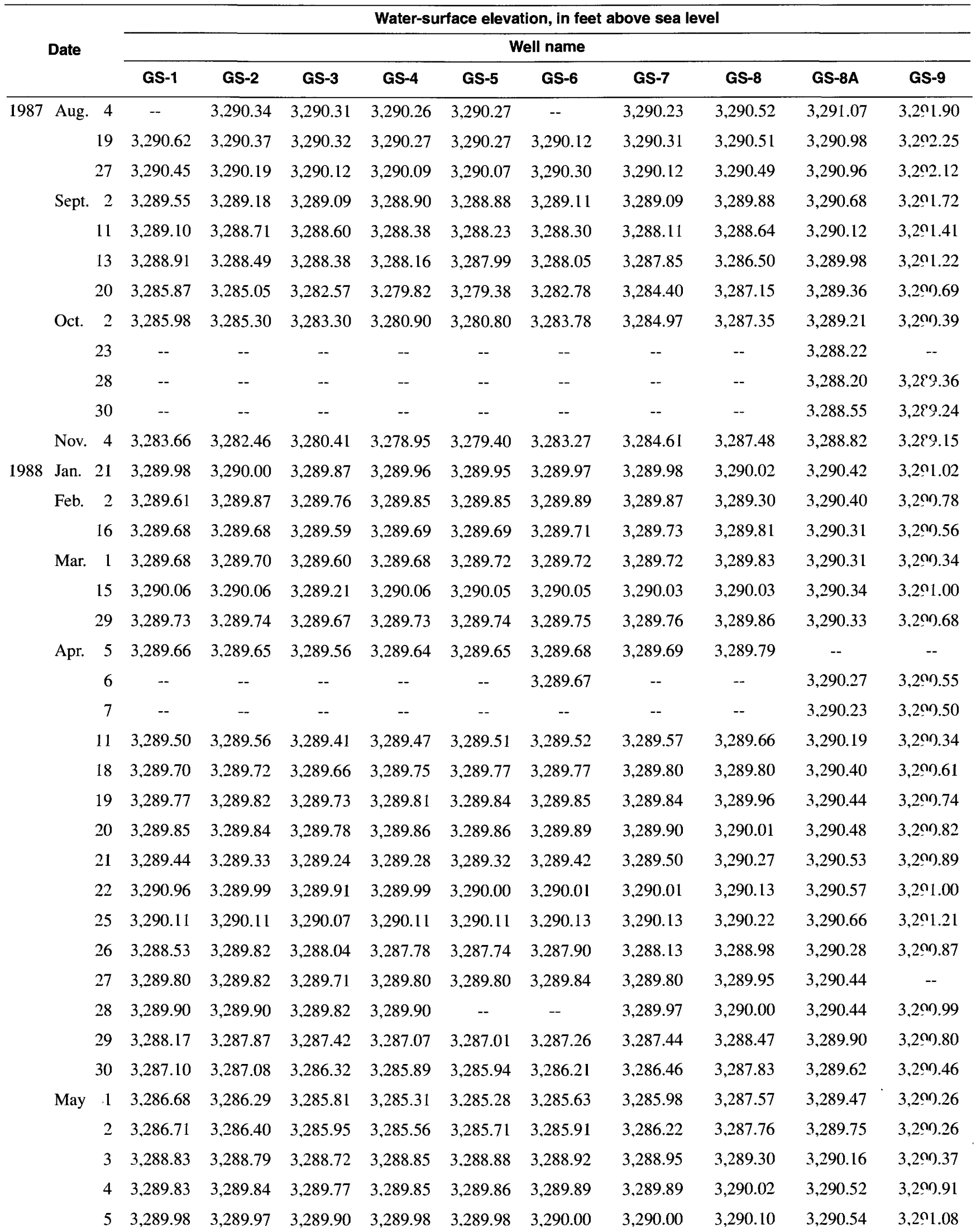


Table 15. Water-level data for observation-well network at Girl Scout Gallery-Continued $[-$, no data $]$

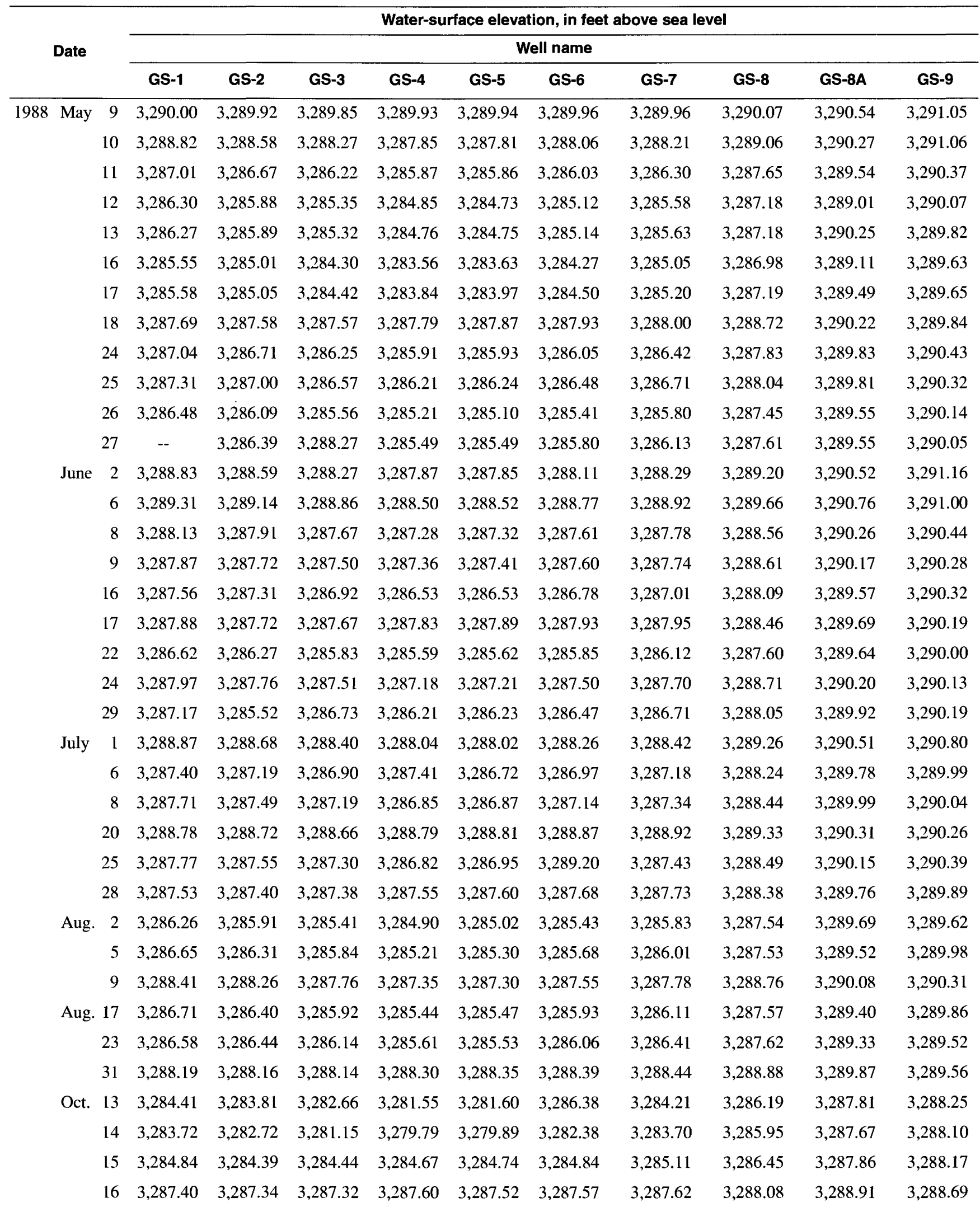


Table 15. Water-level data for observation-well network at Girl Scout Gallery-Continued [--, no data]

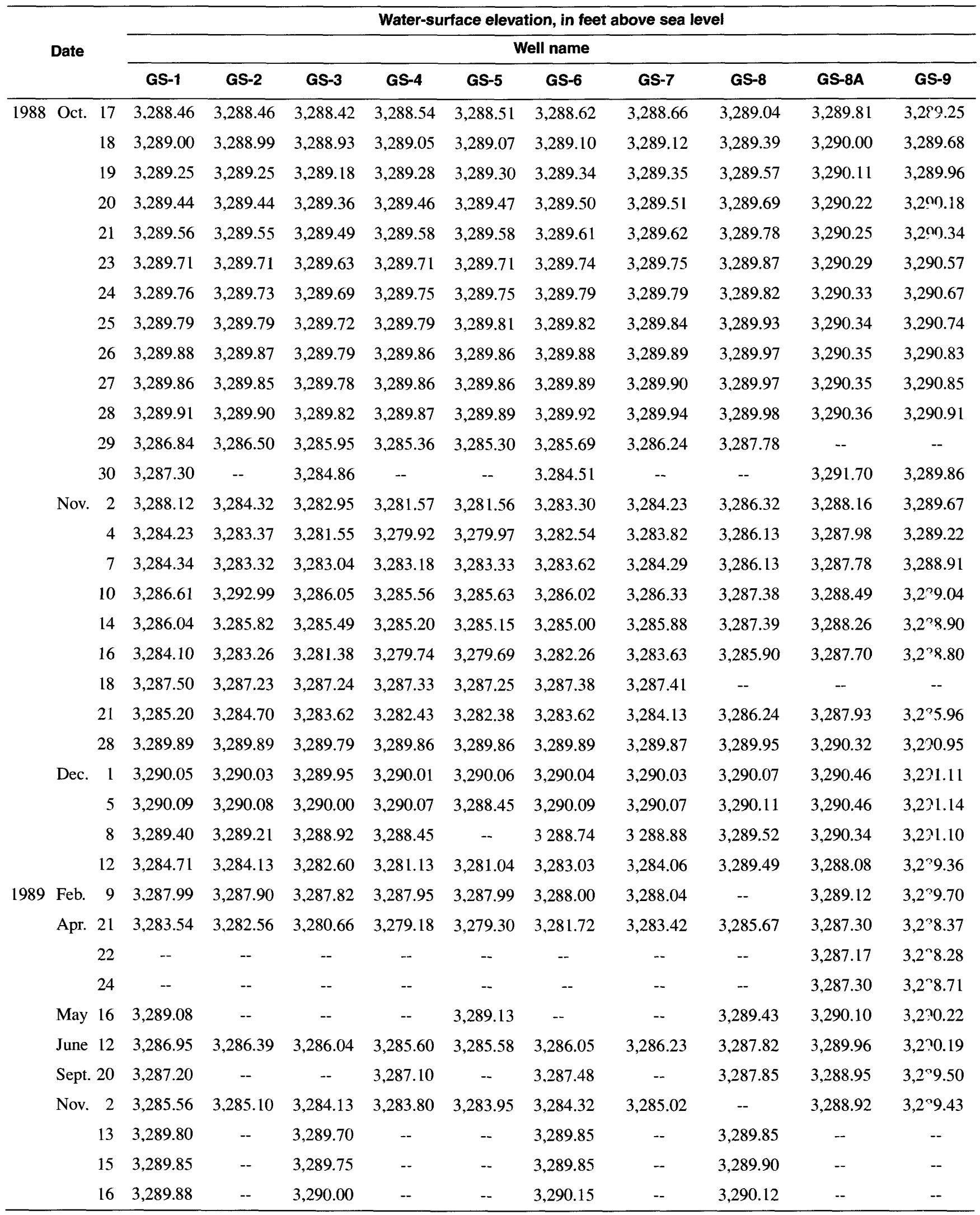


Table 16. Water-level data for observation-well network near Water Treatment Plant $[--$, no data]

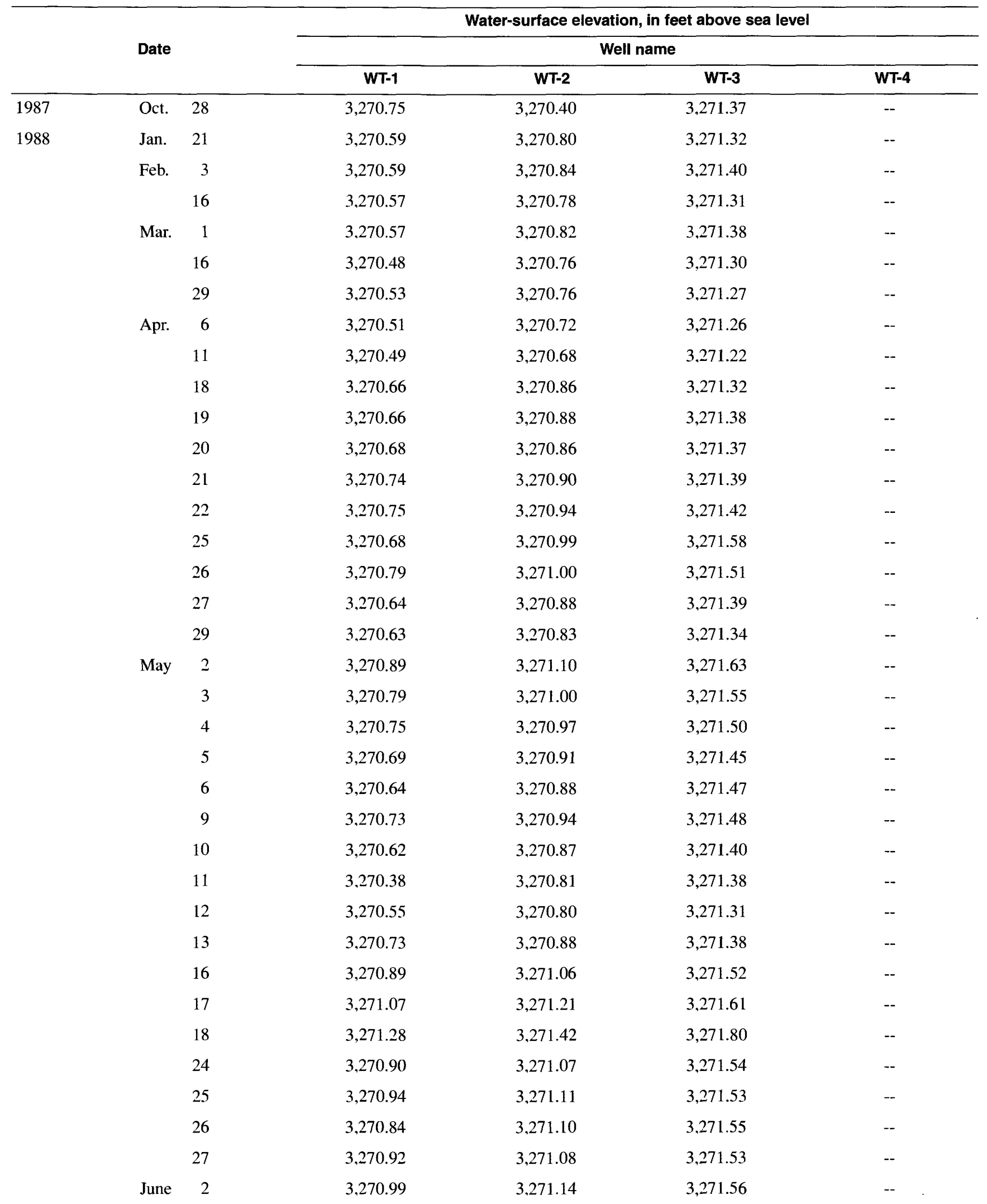


Table 16. Water-level data for observation-well network near Water Treatment Plant—Continued [--, no data]

\begin{tabular}{|c|c|c|c|c|c|c|}
\hline & & & \multicolumn{4}{|c|}{ Water-surface elevation, in feet above sea level } \\
\hline & \multicolumn{2}{|l|}{ Date } & WT-1 & WT-2 & WT-3 & WT-4 \\
\hline \multirow[t]{16}{*}{1988} & June & 6 & $3,271.04$ & $3,271.14$ & $3,271.54$ & -- \\
\hline & & 8 & $3,271.03$ & $3,271.16$ & $3,271.53$ & -- \\
\hline & & 17 & $3,271.19$ & $3,271.22$ & $3,271.56$ & -- \\
\hline & & 22 & $3,271.28$ & $3,271.40$ & $3,271.69$ & -- \\
\hline & & 23 & $3,271.43$ & 3.271 .52 & $3,271.82$ & -- \\
\hline & July & 1 & $3,271.41$ & $3,271.52$ & $3,271.86$ & -- \\
\hline & & 6 & $3,271.27$ & $3,271.36$ & $3,271.67$ & -- \\
\hline & & 8 & 3.271 .37 & $3,271.51$ & $3,271.80$ & -- \\
\hline & & 15 & $3,271.50$ & $3,271.52$ & $3,271.79$ & -- \\
\hline & & 20 & $3,271.29$ & $3,271.40$ & $3,271.72$ & -- \\
\hline & & 25 & $3,271.39$ & $3,271.46$ & $3,271.75$ & -- \\
\hline & & 28 & $3,271.25$ & $3,271.34$ & $3,271.67$ & -- \\
\hline & Oct. & 2 & -- & -- & -- & $3,271.48$ \\
\hline & & 12 & $3,270.41$ & $3,270.62$ & $3,271.06$ & -- \\
\hline & & 18 & $3,270.52$ & $3,270.73$ & $3,271.20$ & $3,271.66$ \\
\hline & Dec. & 5 & $3,270.48$ & $3,270.71$ & $3,271.22$ & $3,271.76$ \\
\hline \multirow[t]{10}{*}{1989} & Mar. & 20 & $3,270.41$ & $3,270.65$ & $3,271.22$ & $3,271.79$ \\
\hline & Apr. & 3 & $3,270.37$ & $3,270.60$ & $3,271.14$ & $3,271.70$ \\
\hline & May & 1 & 3.270 .37 & $3,270.62$ & $3,271.18$ & $3,271.76$ \\
\hline & & 16 & $3,270.60$ & 3.270 .80 & $3,271.34$ & $3,271.89$ \\
\hline & June & 6 & 3.270 .86 & 3.271 .20 & $3,271.62$ & $3,272.01$ \\
\hline & & 20 & $3,271.01$ & 3.271 .15 & 3.271 .55 & $3,271.88$ \\
\hline & & 28 & -- & $3,270.91$ & -- & -- \\
\hline & July & 10 & $3,271.21$ & 3.271 .33 & $3,271.64$ & $3,271.93$ \\
\hline & Aug. & 18 & $3,270.66$ & $3,270.85$ & $3,271.33$ & $3,271.77$ \\
\hline & Nov. & 8 & -- & $3,271.02$ & 3.271 .61 & $3,272.13$ \\
\hline
\end{tabular}




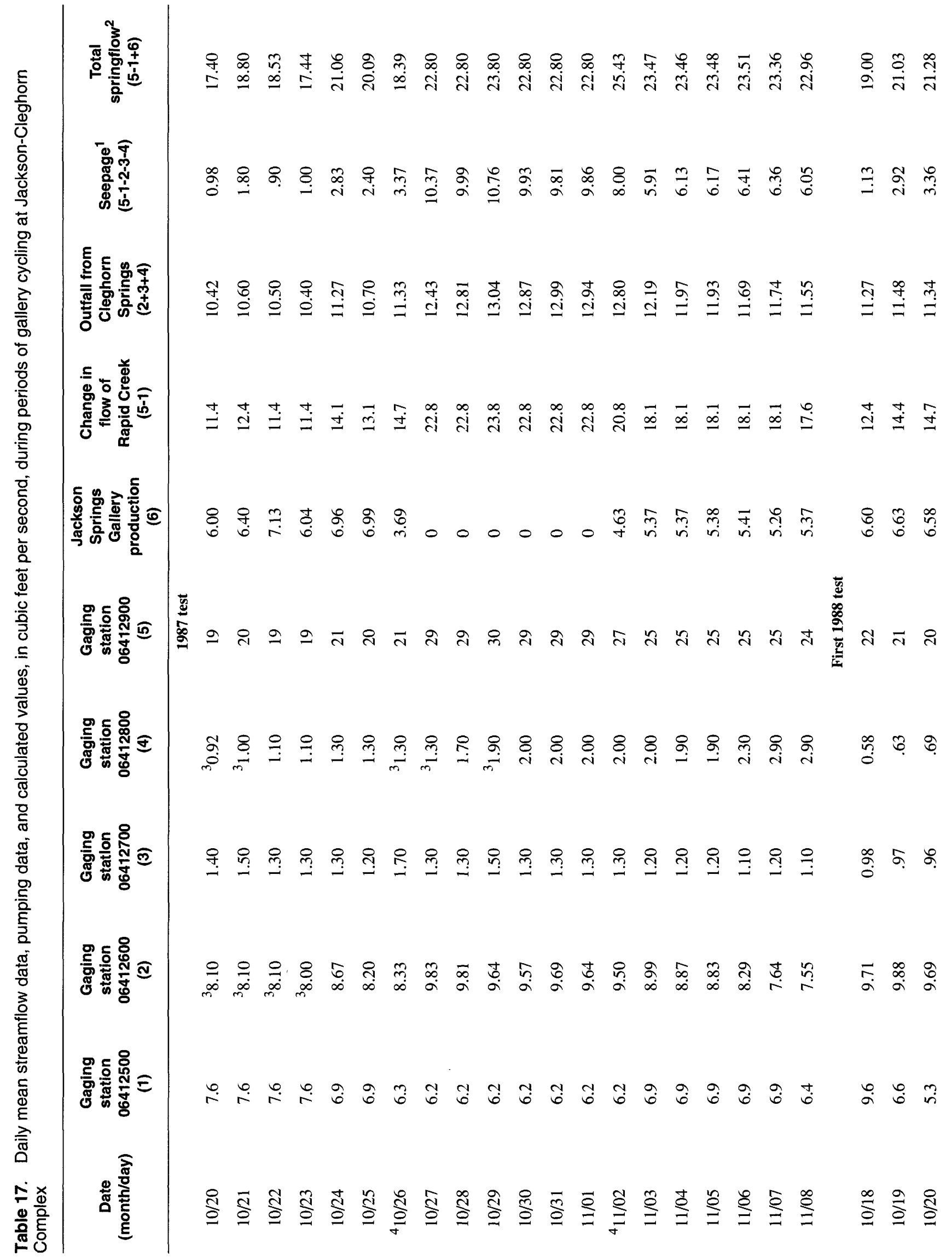




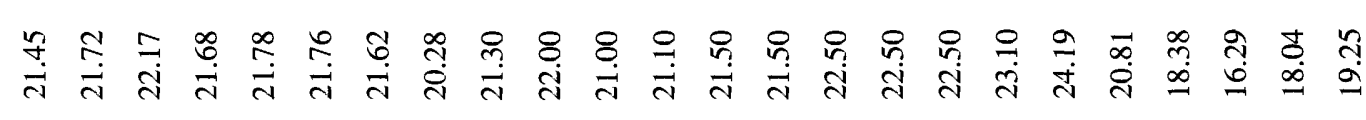

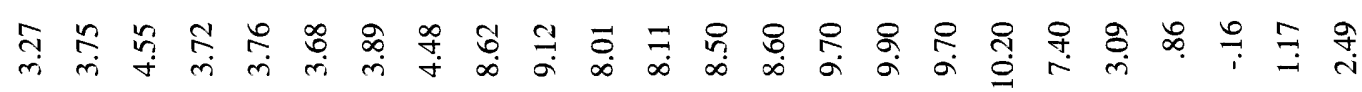

थँํ.

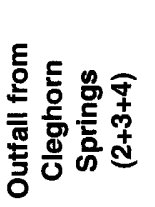

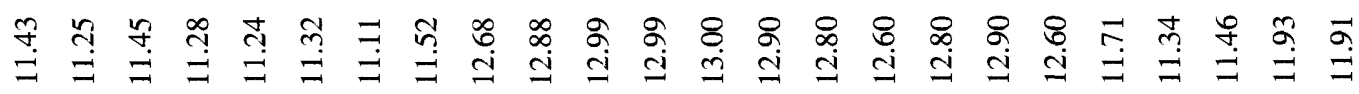

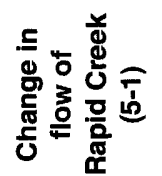

广்

$\frac{\text { 은 }}{\frac{5}{5}}$

סृ

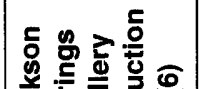

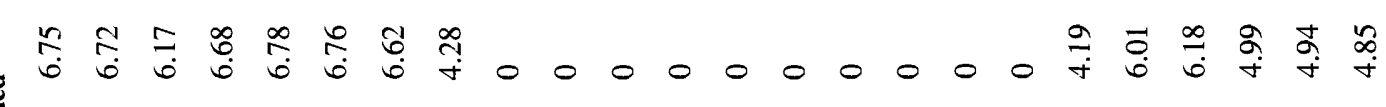
焉

$\frac{\Phi}{\frac{0}{3}}$

오을

囆 霖

(1)

용

(1)

产

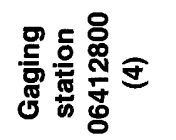

竧

คำ ๆ

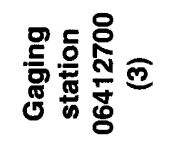

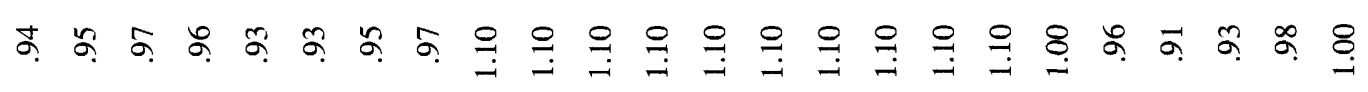

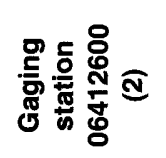

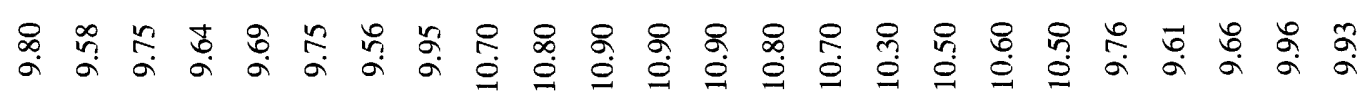

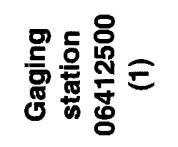

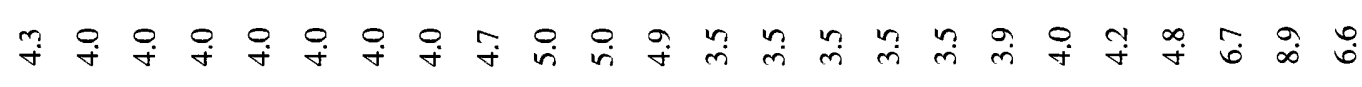

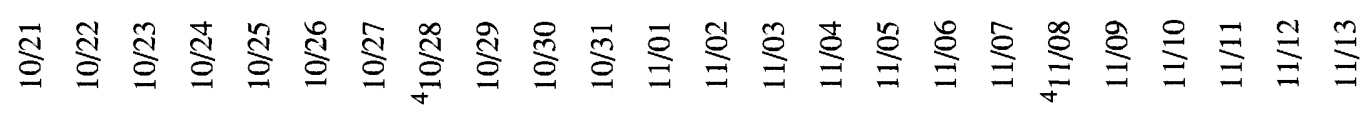




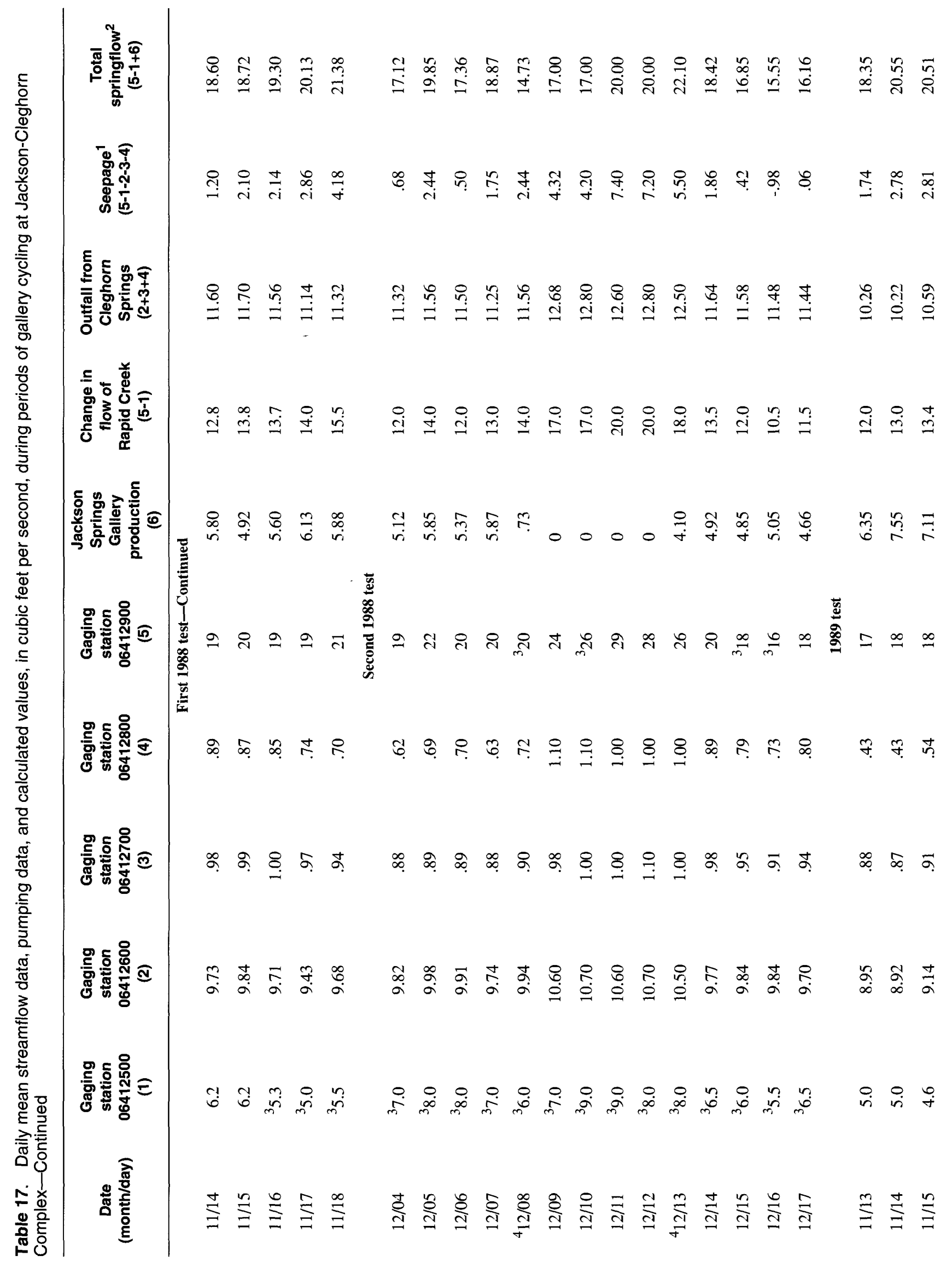




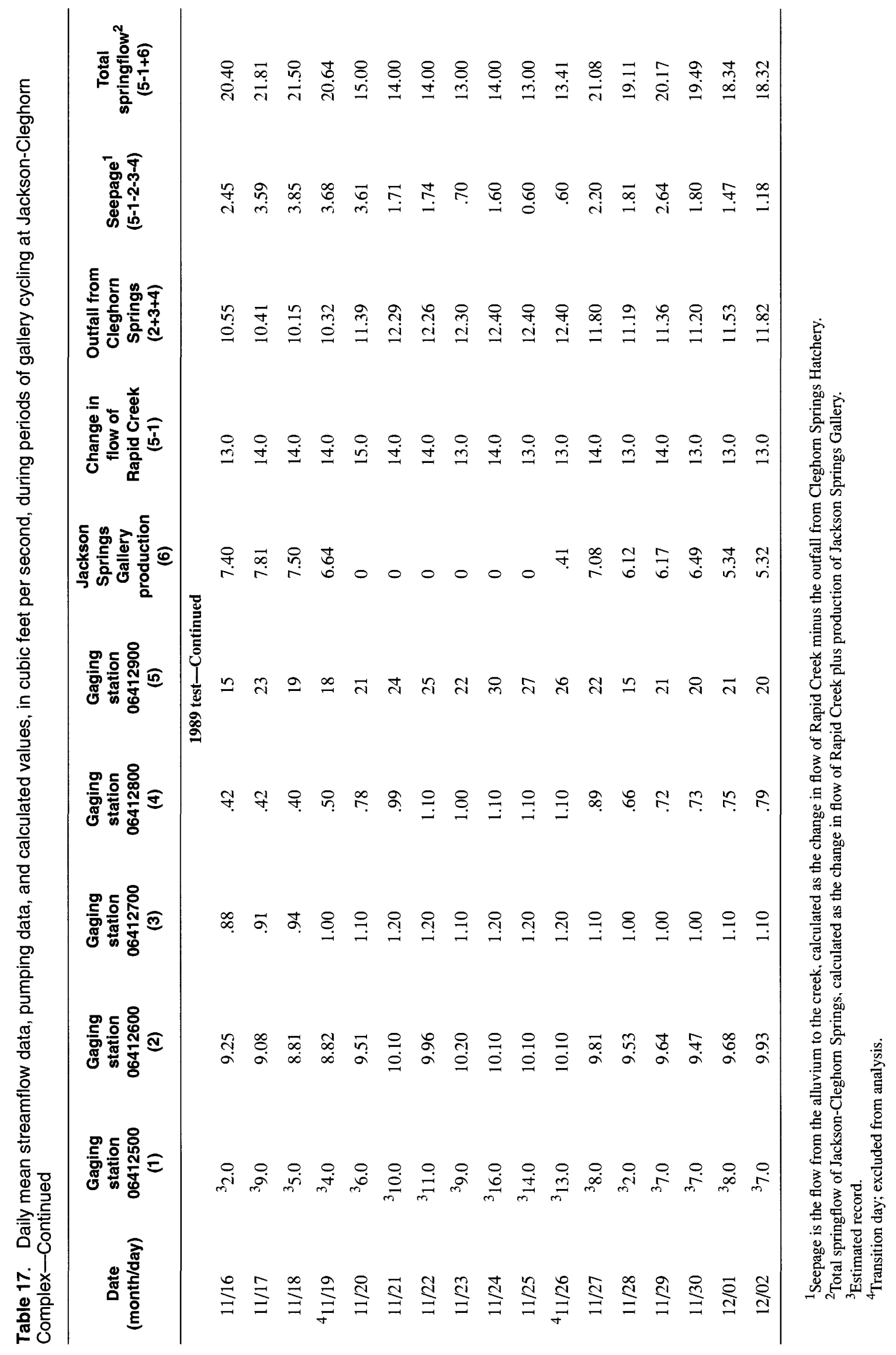


Table 18. Field measurements and calculated values of dissolved nitrogen and oxygen for selected sites in study area

[yymmdd, year, month, day; ${ }^{\circ} \mathrm{C}$, degrees Celsius; mm Hg, millimeters of mercury; mg/L, milligrams per liter]

\begin{tabular}{|c|c|c|c|c|c|c|c|c|c|}
\hline $\begin{array}{c}\text { Station } \\
\text { identification } \\
\text { number }\end{array}$ & $\begin{array}{c}\text { Date } \\
\text { (yymmdd) }\end{array}$ & $\begin{array}{c}\text { Time } \\
\text { (hours) }\end{array}$ & $\begin{array}{c}\text { Water } \\
\text { tempera- } \\
\text { ture } \\
\left({ }^{\circ} \mathrm{C}\right)\end{array}$ & $\begin{array}{c}\text { Baro- } \\
\text { metric } \\
\text { pressure } \\
(\mathrm{mm} \mathrm{Hg})\end{array}$ & $\begin{array}{c}\text { Dissolved } \\
\text { oxygen } \\
\text { (mg/L) }\end{array}$ & $\begin{array}{c}\text { Weiss } \\
\text { reading } \\
(\mathrm{mm} \mathrm{Hg})\end{array}$ & $\begin{array}{c}\mathrm{N}_{2} \\
\text { (percent } \\
\text { satura- } \\
\text { tion) }\end{array}$ & $\begin{array}{c}N_{2} \\
(m g / L)\end{array}$ & $\begin{array}{c}\mathrm{O}_{2} \\
\text { (percent } \\
\text { satura- } \\
\text { tion) }\end{array}$ \\
\hline \multicolumn{10}{|c|}{ Rapid Creek above Jackson Springs } \\
\hline \multirow[t]{4}{*}{440322103181301} & 870714 & 0847 & 12.0 & 676.0 & 11.4 & 15 & 97.76 & 15.09 & 119.10 \\
\hline & 870727 & 1030 & 15.5 & 673.0 & 10.9 & 28 & 99.06 & 14.17 & 123.70 \\
\hline & 870807 & 0845 & 13.0 & 676.0 & 7.7 & -2 & 104.20 & 15.76 & 82.36 \\
\hline & 870813 & 0940 & 14.0 & 668.0 & 8.6 & 26 & 106.20 & 15.55 & 95.22 \\
\hline \multicolumn{10}{|c|}{ Jackson Springs pumphouse } \\
\hline \multirow[t]{4}{*}{440327103180501} & 870604 & 0945 & 11.0 & 677.0 & 6.0 & 26 & 115.20 & 18.19 & 61.20 \\
\hline & 870612 & 1420 & 11.0 & 673.0 & 7.2 & 55 & 117.40 & 18.42 & 73.89 \\
\hline & 870615 & 0945 & 11.0 & 673.0 & 6.3 & 25 & 114.10 & 17.91 & 64.65 \\
\hline & 870901 & 0935 & 14.0 & 681.0 & 10.3 & 24 & 101.40 & 15.13 & 111.80 \\
\hline \multicolumn{10}{|c|}{ Jackson Springs west manhole } \\
\hline \multirow[t]{24}{*}{440327103180502} & 870211 & 1435 & 10.0 & 677.0 & 6.8 & 55 & 118.90 & 19.19 & 67.75 \\
\hline & 870309 & 1320 & 9.3 & 679.0 & 5.8 & 53 & 121.40 & 19.96 & 56.66 \\
\hline & 870310 & 1530 & 9.0 & 677.0 & 7.3 & 53 & 117.70 & 19.41 & 71.01 \\
\hline & 870311 & 0845 & 8.5 & 677.0 & 6.3 & 55 & 120.80 & 20.16 & 60.54 \\
\hline & 870312 & 1020 & 8.0 & 679.0 & 9.4 & 57 & 113.60 & 19.23 & 88.97 \\
\hline & 870313 & 1050 & 8.5 & 671.0 & 9.8 & 60 & 112.70 & 18.64 & 95.04 \\
\hline & 870318 & 1620 & 8.0 & 664.0 & 7.0 & 55 & 119.10 & 19.70 & 67.77 \\
\hline & 870320 & 1145 & 9.0 & 664.0 & 7.7 & 50 & 115.90 & 18.74 & 76.39 \\
\hline & 870324 & 1230 & 8.5 & 672.0 & 8.0 & 52 & 115.80 & 19.18 & 77.46 \\
\hline & 870327 & 1130 & 7.5 & 679.0 & 7.8 & 50 & 116.50 & 19.95 & 72.92 \\
\hline & 870330 & 1515 & 9.0 & 676.0 & 7.4 & 50 & 116.80 & 19.25 & 72.09 \\
\hline & 870403 & 1140 & 9.2 & 679.0 & 7.3 & 50 & 117.00 & 19.28 & 71.14 \\
\hline & 870407 & 1140 & 10.5 & 683.0 & 6.8 & 50 & 117.80 & 18.98 & 67.94 \\
\hline & 870410 & 1115 & 9.0 & 669.0 & 8.8 & 53 & 113.60 & 18.53 & 86.64 \\
\hline & 870414 & 1700 & 10.0 & 676.0 & 7.1 & 50 & 117.20 & 18.88 & 70.85 \\
\hline & 870417 & 0830 & 9.0 & 669.0 & 7.4 & 35 & 113.80 & 18.56 & 72.86 \\
\hline & 870421 & 1310 & 11.5 & 683.0 & 9.5 & 27 & 105.80 & 16.68 & 97.17 \\
\hline & 870424 & 1105 & 9.8 & 677.0 & 6.5 & 33 & 115.60 & 18.74 & 64.45 \\
\hline & 870428 & 0910 & 10.0 & 677.0 & 7.8 & 43 & 114.00 & 18.40 & 77.71 \\
\hline & 870501 & 1130 & 10.4 & 667.0 & 6.5 & 40 & 116.60 & 18.37 & 66.37 \\
\hline & 870505 & 1445 & 10.0 & 682.0 & 6.8 & 28 & 113.90 & 18.52 & 67.25 \\
\hline & 870507 & 0925 & 10.5 & 681.0 & 7.6 & 30 & 111.90 & 17.97 & 76.17 \\
\hline & 870512 & 1400 & 10.8 & 671.0 & 6.4 & 25 & 113.90 & 17.90 & 65.57 \\
\hline & 870604 & 0945 & 11.0 & 677.0 & 6.0 & 26 & 115.20 & 18.19 & 61.20 \\
\hline
\end{tabular}


Table 18. Field measurements and calculated values of dissolved nitrogen and oxygen for selected sites in study area-Continued

[yymmdd, year, month, day; ${ }^{\circ} \mathrm{C}$, degrees Celsius; $\mathrm{mm} \mathrm{Hg}$, millimeters of mercury; $\mathrm{mg} / \mathrm{L}$, milligrams per liter]

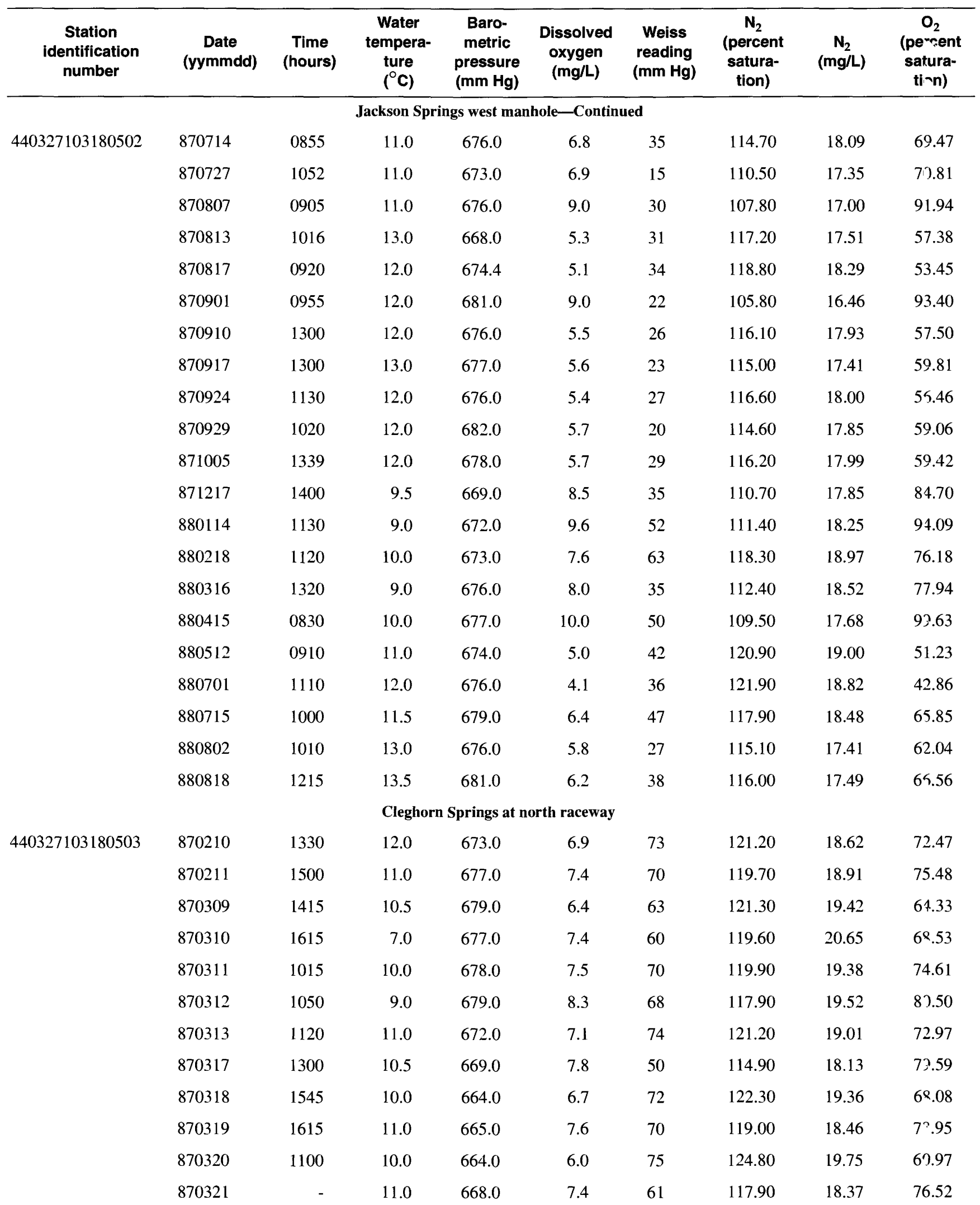


Table 18. Field measurements and calculated values of dissolved nitrogen and oxygen for selected sites in study area-Continued

[yymmdd, year, month, day; ${ }^{\circ} \mathrm{C}$, degrees Celsius; mm Hg, millimeters of mercury; mg/L, milligrams per liter]

\begin{tabular}{|c|c|c|c|c|c|c|c|c|c|}
\hline $\begin{array}{c}\text { Station } \\
\text { identification } \\
\text { number }\end{array}$ & $\begin{array}{c}\text { Date } \\
\text { (yymmdd) }\end{array}$ & $\begin{array}{c}\text { Time } \\
\text { (hours) }\end{array}$ & $\begin{array}{c}\text { Water } \\
\text { tempera- } \\
\text { ture } \\
\left.{ }^{\circ} \mathrm{C}\right)\end{array}$ & $\begin{array}{c}\text { Baro- } \\
\text { metric } \\
\text { pressure } \\
(\mathrm{mm} \mathrm{Hg})\end{array}$ & $\begin{array}{c}\text { Dissolved } \\
\text { oxygen } \\
\text { (mg/L) }\end{array}$ & $\begin{array}{c}\text { Weiss } \\
\text { reading } \\
(\mathrm{mm} \mathrm{Hg})\end{array}$ & $\begin{array}{c}\mathrm{N}_{2} \\
\text { (percent } \\
\text { satura- } \\
\text { tion) }\end{array}$ & $\begin{array}{c}\mathrm{N}_{2} \\
(\mathrm{mg} / \mathrm{L})\end{array}$ & $\begin{array}{c}\mathrm{O}_{2} \\
\text { (percent } \\
\text { satura- } \\
\text { tion) }\end{array}$ \\
\hline \multicolumn{10}{|c|}{ Cleghorn Springs at north raceway_Continued } \\
\hline \multirow[t]{34}{*}{440327103180503} & 870322 & - & 11.0 & 668.0 & 7.0 & 55 & 117.80 & 18.36 & 72.38 \\
\hline & 870323 & 1435 & 10.0 & 671.0 & 7.8 & 68 & 118.70 & 18.98 & 78.42 \\
\hline & 870324 & 1140 & 10.0 & 673.0 & 7.4 & 60 & 118.20 & 18.97 & 74.17 \\
\hline & 870327 & 1150 & 10.0 & 681.0 & 7.3 & 60 & 118.60 & 19.25 & 72.30 \\
\hline & 870330 & 1540 & 11.2 & 677.0 & 6.8 & 60 & 119.40 & 18.77 & 69.69 \\
\hline & 870403 & 1100 & 12.0 & 679.0 & 7.4 & 60 & 117.40 & 18.21 & 77.02 \\
\hline & 870407 & 1045 & 13.8 & 683.0 & 7.2 & 63 & 117.80 & 17.70 & 77.59 \\
\hline & 870410 & 1145 & 10.8 & 669.0 & 7.2 & 73 & 120.80 & 18.94 & 73.99 \\
\hline & 870414 & 1620 & 10.5 & 676.0 & 7.2 & 67 & 119.90 & 19.11 & 72.70 \\
\hline & 870417 & 0910 & 11.0 & 669.0 & 8.4 & 52 & 113.40 & 17.70 & 86.73 \\
\hline & 870421 & 1355 & 11.2 & 683.0 & 7.2 & 58 & 118.00 & 18.72 & 73.13 \\
\hline & 870424 & 1130 & 10.5 & 677.0 & 6.9 & 67 & 120.70 & 19.27 & 69.56 \\
\hline & 870428 & 0930 & 10.8 & 677.0 & 8.4 & 70 & 117.10 & 18.58 & 85.29 \\
\hline & 870501 & 1050 & 11.0 & 667.0 & 7.2 & 80 & 122.10 & 18.99 & 74.56 \\
\hline & 870505 & 1505 & 11.0 & 682.0 & 6.6 & 62 & 120.40 & 19.16 & 66.82 \\
\hline & 870507 & 1030 & 11.0 & 681.0 & 6.7 & 60 & 119.70 & 19.03 & 67.94 \\
\hline & 870512 & 1420 & 10.8 & 671.0 & 6.4 & 65 & 121.50 & 19.10 & 65.57 \\
\hline & 870521 & 1400 & 11.0 & 674.0 & 6.8 & 58 & 119.00 & 18.71 & 69.68 \\
\hline & 870604 & 1000 & 12.0 & 677.0 & 6.0 & 52 & 119.70 & 18.51 & 62.64 \\
\hline & 870612 & 1420 & 11.0 & 673.0 & 7.2 & 55 & 117.40 & 18.42 & 73.89 \\
\hline & 870615 & 1015 & 11.0 & 673.0 & 6.0 & 48 & 119.30 & 18.73 & 61.57 \\
\hline & 870626 & 0845 & 11.0 & 677.0 & 6.1 & 45 & 118.50 & 18.71 & 62.22 \\
\hline & 870714 & 0940 & 11.0 & 676.0 & 6.0 & 41 & 118.00 & 18.61 & 61.29 \\
\hline & 870727 & 1111 & 12.0 & 673.0 & 5.7 & 40 & 118.20 & 18.17 & 59.86 \\
\hline & 870807 & 0945 & 14.0 & 676.0 & 4.4 & 28 & 119.00 & 17.63 & 48.13 \\
\hline & 870811 & 0815 & 12.0 & 668.0 & 5.5 & 62 & 122.90 & 18.75 & 58.20 \\
\hline & 870817 & 0945 & 11.5 & 674.4 & 5.6 & 55 & 121.50 & 18.92 & 58.02 \\
\hline & 870901 & 1025 & 12.0 & 681.0 & 5.9 & 46 & 118.90 & 18.49 & 61.22 \\
\hline & 870910 & 1345 & 12.0 & 677.0 & 5.5 & 38 & 118.40 & 18.31 & 57.42 \\
\hline & 870917 & 1300 & 12.0 & 677.0 & 5.1 & 34 & 118.80 & 18.37 & 53.24 \\
\hline & 870925 & 1110 & 12.0 & 673.0 & 4.9 & 55 & 123.30 & 18.95 & 51.46 \\
\hline & 870929 & 1045 & 12.0 & 682.0 & 5.0 & 30 & 118.40 & 18.44 & 51.81 \\
\hline & 871005 & 1350 & 12.0 & 678.0 & 6.4 & 42 & 116.70 & 18.08 & 66.71 \\
\hline & 880114 & 1200 & 9.0 & 671.0 & 9.2 & 43 & 110.70 & 18.11 & 90.31 \\
\hline
\end{tabular}


Table 18. Field measurements and calculated values of dissolved nitrogen and oxygen for selected sites in study area-Continued

[yymmdd, year, month, day; ${ }^{\circ} \mathrm{C}$, degrees Celsius; $\mathrm{mm} \mathrm{Hg}$, millimeters of mercury; $\mathrm{mg} / \mathrm{L}$, milligrams per liter]

\begin{tabular}{|c|c|c|c|c|c|c|c|c|c|}
\hline $\begin{array}{c}\text { Station } \\
\text { identification } \\
\text { number }\end{array}$ & $\begin{array}{c}\text { Date } \\
\text { (yymmdd) }\end{array}$ & $\begin{array}{c}\text { Time } \\
\text { (hours) }\end{array}$ & $\begin{array}{l}\text { Water } \\
\text { tempera- } \\
\text { ture } \\
\left.{ }^{\circ} \mathrm{C}\right)\end{array}$ & $\begin{array}{c}\text { Baro- } \\
\text { metric } \\
\text { pressure } \\
(\mathrm{mm} \mathrm{Hg})\end{array}$ & $\begin{array}{l}\text { Dissolved } \\
\text { oxygen } \\
\text { (mg/L) }\end{array}$ & $\begin{array}{l}\text { Weiss } \\
\text { reading } \\
(\mathrm{mm} \mathrm{Hg})\end{array}$ & $\begin{array}{c}\mathrm{N}_{2} \\
\text { (percent } \\
\text { satura- } \\
\text { tion) }\end{array}$ & $\begin{array}{c}\mathrm{N}_{2} \\
(\mathrm{mg} / \mathrm{L})\end{array}$ & $\begin{array}{c}\mathrm{O}_{2} \\
\text { (pe"sent } \\
\text { satura- } \\
\text { ti n) }\end{array}$ \\
\hline \multirow[t]{25}{*}{440327103180506} & 870210 & 1430 & 8.0 & 673.0 & 10.2 & 23 & 105.00 & 17.61 & 97.42 \\
\hline & 870211 & 1450 & 5.0 & 677.0 & 12.0 & 30 & 104.10 & 18.84 & $10\ulcorner .60$ \\
\hline & 870310 & 1550 & 3.0 & 677.0 & 12.5 & 18 & 102.20 & 19.41 & 104.30 \\
\hline & 870311 & 0830 & 0 & 677.0 & 12.8 & 10 & 102.20 & 20.97 & $9 ? .43$ \\
\hline & 870312 & 1000 & 0 & 679.0 & 14.6 & 12 & 99.08 & 20.37 & 111.90 \\
\hline & 870324 & 1215 & .5 & 672.0 & 13.6 & 5 & 99.12 & 19.91 & $10 \div .80$ \\
\hline & 870327 & 1115 & 2.5 & 679.0 & 10.4 & 5 & 104.70 & 20.21 & 85.43 \\
\hline & 870330 & 1455 & 6.5 & 676.0 & 10.8 & 23 & 104.60 & 18.24 & $9 ? .92$ \\
\hline & 870403 & 1120 & 6.0 & 679.0 & 12.0 & 25 & 102.50 & 18.17 & 103.00 \\
\hline & 870407 & 1125 & 6.5 & 683.0 & 11.5 & 25 & 103.50 & 18.24 & 104.20 \\
\hline & 870410 & 1100 & 4.1 & 669.0 & 14.4 & 13 & 95.77 & 17.49 & 125.30 \\
\hline & 870414 & 1645 & 9.0 & 676.0 & 11.0 & 13 & 100.50 & 16.56 & 107.10 \\
\hline & 870507 & 0925 & 10.5 & 681.0 & 11.2 & 17 & 99.95 & 16.05 & 112.20 \\
\hline & 870512 & 1340 & 16.0 & 671.0 & 10.2 & 40 & 103.00 & 14.55 & 117.40 \\
\hline & 870521 & 1320 & 11.5 & 674.0 & 9.1 & 48 & 110.60 & 17.20 & 94.34 \\
\hline & 870602 & 1415 & 11.0 & 674.0 & 10.8 & 40 & 104.70 & 16.47 & 110.60 \\
\hline & 870604 & 0930 & 13.0 & 677.0 & 10.0 & 43 & 106.30 & 16.10 & 105.80 \\
\hline & 870612 & 1355 & 22.0 & 673.0 & 11.9 & 70 & 99.11 & 12.55 & 154.40 \\
\hline & 870615 & 0935 & 14.0 & 672.0 & 10.4 & 38 & 103.40 & 15.22 & 114.40 \\
\hline & 870714 & 0847 & 12.0 & 676.0 & 11.4 & 15 & 97.76 & 15.09 & 119.10 \\
\hline & 870727 & 1030 & 15.5 & 673.0 & 10.9 & 28 & 99.06 & 14.17 & 123.70 \\
\hline & 870813 & 0940 & 14.0 & 668.0 & 8.6 & 26 & 106.20 & 15.55 & 95.22 \\
\hline & 870817 & 0900 & 18.0 & 674.4 & 9.1 & 42 & 105.70 & 14.44 & $10 ? .70$ \\
\hline & 870901 & 0935 & 14.0 & 681.0 & 10.3 & 24 & 101.40 & 15.13 & 111.80 \\
\hline & 870910 & 1240 & 14.0 & 676.0 & 10.4 & 33 & 102.60 & 15.20 & 113.70 \\
\hline
\end{tabular}


Table 18. Field measurements and calculated values of dissolved nitrogen and oxygen for selected sites in study area-Continued

[yymmdd, year. month, day; ${ }^{\circ} \mathrm{C}$, degrees Celsius; mm Hg. millimeters of mercury; $\mathrm{mg} / \mathrm{L}$, milligrams per liter]

\begin{tabular}{|c|c|c|c|c|c|c|c|c|c|}
\hline $\begin{array}{c}\text { Station } \\
\text { identification } \\
\text { number }\end{array}$ & $\begin{array}{c}\text { Date } \\
\text { (yymmdd) }\end{array}$ & $\begin{array}{c}\text { Time } \\
\text { (hours) }\end{array}$ & $\begin{array}{c}\text { Water } \\
\text { tempera- } \\
\text { ture } \\
\left({ }^{\circ} \mathrm{C}\right)\end{array}$ & $\begin{array}{c}\text { Baro- } \\
\text { metric } \\
\text { pressure } \\
(\mathbf{m m ~ H g})\end{array}$ & $\begin{array}{l}\text { Dissolved } \\
\text { oxygen } \\
\text { (mg/L) }\end{array}$ & $\begin{array}{c}\text { Weiss } \\
\text { reading } \\
(\mathbf{m m ~ H g})\end{array}$ & $\begin{array}{c}\mathrm{N}_{2} \\
\text { (percent } \\
\text { satura- } \\
\text { tion) }\end{array}$ & $\begin{array}{c}\mathrm{N}_{2} \\
(\mathrm{mg} / \mathrm{L})\end{array}$ & $\begin{array}{c}\mathrm{O}_{2} \\
\text { (percent } \\
\text { satura- } \\
\text { tion) }\end{array}$ \\
\hline \multirow[t]{8}{*}{440327103180506} & 870917 & 1245 & 14.0 & 677.0 & 11.0 & 35 & 101.30 & 15.02 & 120.10 \\
\hline & 871005 & 1315 & 12.0 & 678.0 & 10.9 & 32 & 102.40 & 15.86 & 113.60 \\
\hline & 871217 & 1330 & 1.2 & 669.0 & 12.0 & -9 & 99.18 & 19.48 & 96.57 \\
\hline & 880114 & 1100 & 0 & 672.0 & 8.0 & -4 & 109.30 & 22.24 & 61.98 \\
\hline & 880606 & 1145 & 18.0 & 676.0 & 11.0 & 49 & 101.10 & 13.84 & 131.10 \\
\hline & 880701 & 1145 & 12.0 & 674.0 & 9.8 & 35 & 105.90 & 16.30 & 102.70 \\
\hline & 880802 & 1030 & 14.0 & 677.0 & 8.9 & 20 & 104.50 & 15.50 & 97.20 \\
\hline & 880818 & 1240 & 16.5 & 681.0 & 9.7 & 37 & 104.00 & 14.77 & 111.10 \\
\hline \multicolumn{10}{|c|}{ Cleghorn Gallery northwest manhole } \\
\hline \multirow[t]{2}{*}{440327103180507} & 880606 & 1345 & 14.5 & 669.0 & 6.0 & 50 & 118.30 & 17.17 & 67.06 \\
\hline & 880701 & 0825 & 10.5 & 676.0 & 6.5 & 49 & 118.40 & 18.87 & 65.63 \\
\hline \multirow[t]{12}{*}{440300103173501} & 870409 & 0830 & 12.5 & 673.0 & 5.3 & 55 & 122.00 & 18.56 & 56.30 \\
\hline & 870507 & 0830 & 12.8 & 681.0 & 5.2 & 52 & 121.70 & 18.62 & 54.95 \\
\hline & 870713 & 0938 & 12.5 & 676.0 & 5.2 & 42 & 119.90 & 18.31 & 54.99 \\
\hline & 870818 & 0930 & 13.5 & 673.1 & 5.0 & 43 & 120.30 & 17.92 & 54.32 \\
\hline & 880121 & 0850 & 12.0 & 673.0 & 6.4 & 54 & 118.90 & 18.28 & 67.22 \\
\hline & 880322 & 0930 & 12.0 & 668.0 & 7.0 & 55 & 117.40 & 17.91 & 74.08 \\
\hline & 880517 & 0930 & 13.0 & 664.0 & 4.5 & 77 & 128.40 & 19.06 & 49.01 \\
\hline & 880610 & 0850 & 13.5 & 675.0 & 5.7 & 48 & 119.10 & 17.82 & 61.75 \\
\hline & 880715 & 0910 & 14.5 & 678.0 & 5.2 & 90 & 128.40 & 18.88 & 57.34 \\
\hline & 880727 & 0835 & 13.0 & 678.0 & 4.7 & 78 & 128.00 & 19.41 & 50.12 \\
\hline & 880804 & 0830 & 13.0 & 685.0 & 4.9 & 50 & 122.10 & 18.72 & 51.71 \\
\hline & 880819 & 0930 & 13.5 & 659.0 & 4.7 & 69 & 126.10 & 18.39 & 52.17 \\
\hline
\end{tabular}


Table 18. Field measurements and calculated values of dissolved nitrogen and oxygen for selected sites in study area-Continued

[yymmdd, year, month, day; ${ }^{\circ} \mathrm{C}$, degrees Celsius: $\mathrm{mm} \mathrm{Hg}$. millimeters of mercury; $\mathrm{mg} / \mathrm{L}$, milligrams per liter]

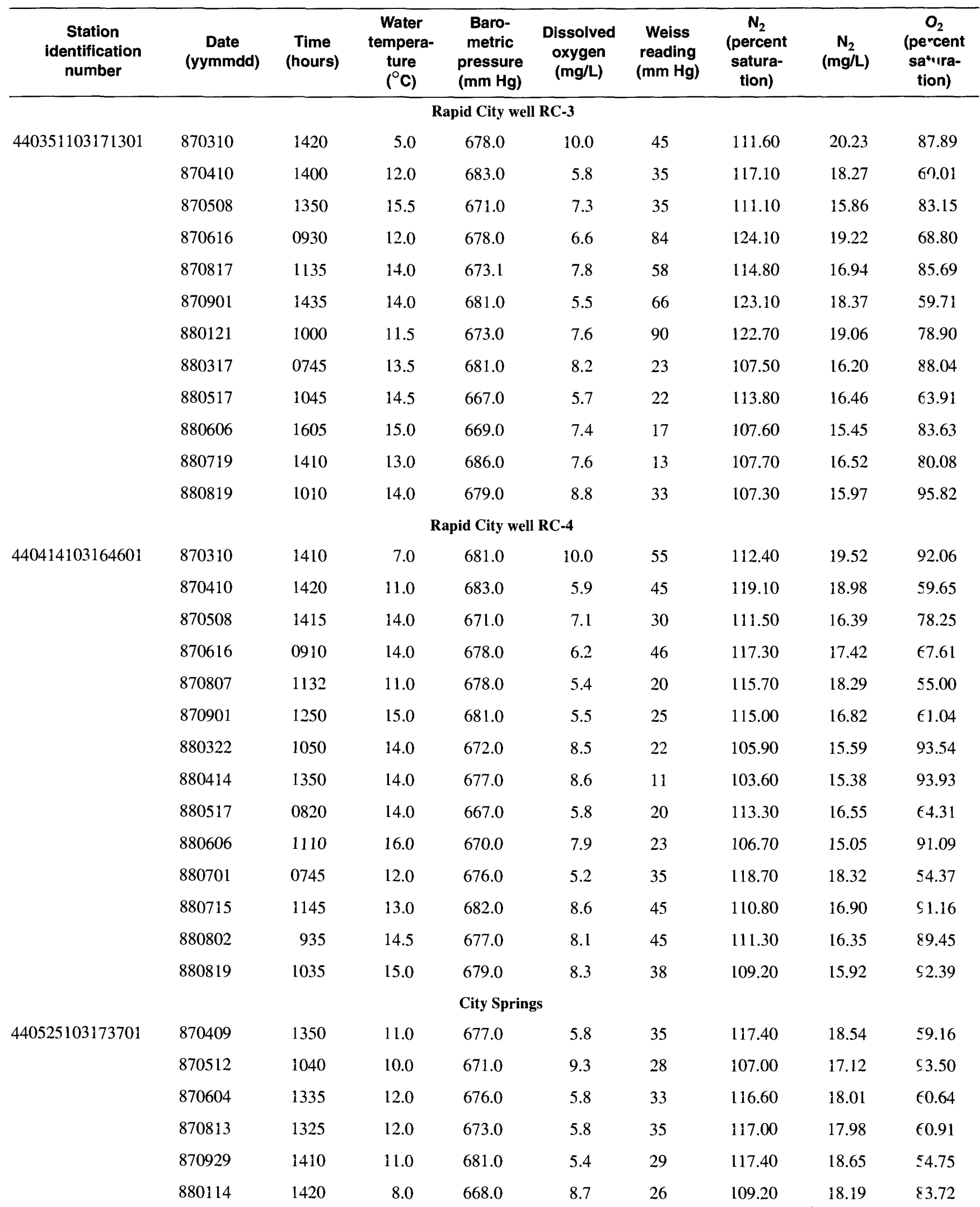


Table 18. Field measurements and calculated values of dissolved nitrogen and oxygen for selected sites in study area-Continued

[yymmdd, year, month, day; ${ }^{\circ} \mathrm{C}$, degrees Celsius; $\mathrm{mm} \mathrm{Hg}$, millimeters of mercury; $\mathrm{mg} / \mathrm{L}$, milligrams per liter]

\begin{tabular}{|c|c|c|c|c|c|c|c|c|c|}
\hline $\begin{array}{c}\text { Station } \\
\text { identification } \\
\text { number }\end{array}$ & $\begin{array}{c}\text { Date } \\
\text { (yymmdd) }\end{array}$ & $\begin{array}{c}\text { Time } \\
\text { (hours) }\end{array}$ & $\begin{array}{c}\text { Water } \\
\text { tempera- } \\
\text { ture } \\
\left({ }^{\circ} \mathrm{C}\right)\end{array}$ & $\begin{array}{c}\text { Baro- } \\
\text { metric } \\
\text { pressure } \\
(\mathbf{m m ~ H g})\end{array}$ & $\begin{array}{c}\text { Dissolved } \\
\text { oxygen } \\
\text { (mg/L) }\end{array}$ & $\begin{array}{l}\text { Weiss } \\
\text { reading } \\
(\mathrm{mm} \mathrm{Hg})\end{array}$ & $\begin{array}{c}\mathrm{N}_{2} \\
\text { (percent } \\
\text { satura- } \\
\text { tion) }\end{array}$ & $\begin{array}{c}\mathrm{N}_{2} \\
(\mathrm{mg} / \mathrm{L})\end{array}$ & $\begin{array}{c}\mathrm{O}_{2} \\
\text { (percent } \\
\text { satura- } \\
\text { tion) }\end{array}$ \\
\hline \multicolumn{10}{|c|}{ City Springs-Continued } \\
\hline \multirow[t]{11}{*}{440525103173701} & 880218 & 1345 & 8.0 & 672.0 & 8.9 & 25 & 108.60 & 18.20 & 85.13 \\
\hline & 880317 & 1315 & 11.0 & 679.0 & 6.7 & 23 & 112.70 & 17.86 & 68.14 \\
\hline & 880414 & 1245 & 11.0 & 674.0 & 6.8 & 30 & 113.70 & 17.88 & 69.68 \\
\hline & 880512 & 1310 & 11.0 & 674.0 & 6.3 & 18 & 112.80 & 17.73 & 64.55 \\
\hline & 880606 & 1630 & 11.0 & 667.0 & 6.9 & 23 & 111.90 & 17.41 & 71.46 \\
\hline & 880630 & 0920 & 10.0 & 674.0 & 5.4 & 19 & 115.70 & 18.60 & 54.04 \\
\hline & 880707 & 0800 & 10.0 & 677.0 & 5.4 & 25 & 116.90 & 18.87 & 53.80 \\
\hline & 880713 & 1505 & 10.5 & 675.0 & 6.4 & 35 & 115.90 & 18.46 & 64.72 \\
\hline & 880728 & 1135 & 12.0 & 678.0 & 8.0 & 47 & 113.30 & 17.54 & 83.39 \\
\hline & 880802 & 0850 & 11.0 & 675.0 & 6.8 & 25 & 112.80 & 17.76 & 69.57 \\
\hline & 880818 & 1100 & 13.0 & 681.0 & 7.4 & 40 & 113.20 & 17.24 & 78.56 \\
\hline \multicolumn{10}{|c|}{ Rapid Creek at Meadowbrook pumphouse } \\
\hline \multirow[t]{19}{*}{440343103163003} & 870702 & 1110 & 16.0 & 675.0 & 8.8 & 24 & 104.30 & 14.83 & 100.70 \\
\hline & 870727 & 0805 & 15.5 & 681.0 & 8.4 & 6 & 102.60 & 14.86 & 94.24 \\
\hline & 870730 & 1435 & 17.0 & 673.0 & 7.5 & 15 & 106.00 & 14.73 & 87.94 \\
\hline & 870807 & 1110 & 17.0 & 678.0 & 7.6 & 2 & 103.40 & 14.48 & 88.44 \\
\hline & 870813 & 1155 & 17.0 & 671.0 & 8.8 & 29 & 104.60 & 14.49 & 103.50 \\
\hline & 870901 & 1410 & 17.5 & 681.0 & 8.3 & 35 & 107.30 & 14.95 & 97.17 \\
\hline & 870910 & 1450 & 16.0 & 677.0 & 9.2 & 31 & 104.50 & 14.90 & 104.90 \\
\hline & 870918 & 0740 & 11.0 & 676.0 & 8.2 & -2 & 103.90 & 16.38 & 83.77 \\
\hline & 870929 & 1125 & 13.0 & 682.0 & 9.2 & 21 & 104.60 & 15.95 & 97.52 \\
\hline & 871005 & 1422 & 13.0 & 678.0 & 9.5 & 33 & 105.90 & 16.05 & 101.30 \\
\hline & 880114 & 1355 & 3.0 & 671.0 & 10.1 & 11 & 106.00 & 19.96 & 85.10 \\
\hline & 880218 & 1320 & 4.5 & 676.0 & 12.0 & 17 & 102.00 & 18.65 & 104.40 \\
\hline & 880316 & 1430 & 6.0 & 679.0 & 11.5 & 24 & 103.50 & 18.35 & 103.50 \\
\hline & 880414 & 1445 & 13.0 & 677.0 & 9.7 & 30 & 104.70 & 15.85 & 103.60 \\
\hline & 880512 & 1030 & 16.0 & 677.0 & 8.5 & 25 & 105.50 & 15.04 & 96.98 \\
\hline & 880606 & 1455 & 20.0 & 670.0 & 8.5 & 18 & 101.70 & 13.30 & 106.50 \\
\hline & 880701 & 1340 & 12.5 & 677.0 & 9.5 & 23 & 104.20 & 15.95 & 100.30 \\
\hline & 880728 & 1300 & 18.0 & 680.0 & 9.2 & 23 & 101.90 & 14.04 & 109.00 \\
\hline & 880818 & 1405 & 17.0 & 682.0 & 9.5 & 23 & 101.70 & 14.32 & 109.80 \\
\hline \multicolumn{10}{|c|}{ Meadowbrook Gallery at No. 5 pumphouse } \\
\hline \multirow[t]{2}{*}{440343103163001} & 870410 & 1340 & 8.0 & 683.0 & 4.4 & 18 & 118.80 & 20.23 & 41.40 \\
\hline & 870508 & 1330 & 13.0 & 678.0 & 5.7 & 23 & 114.70 & 17.39 & 60.78 \\
\hline
\end{tabular}


Table 18. Field measurements and calculated values of dissolved nitrogen and oxygen for selected sites in study area-Continued

[yymmdd, year, month, day; ${ }^{\circ} \mathrm{C}$, degrees Celsius; $\mathrm{mm} \mathrm{Hg}$, millimeters of mercury; $\mathrm{mg} / \mathrm{L}$, milligrams per liter]

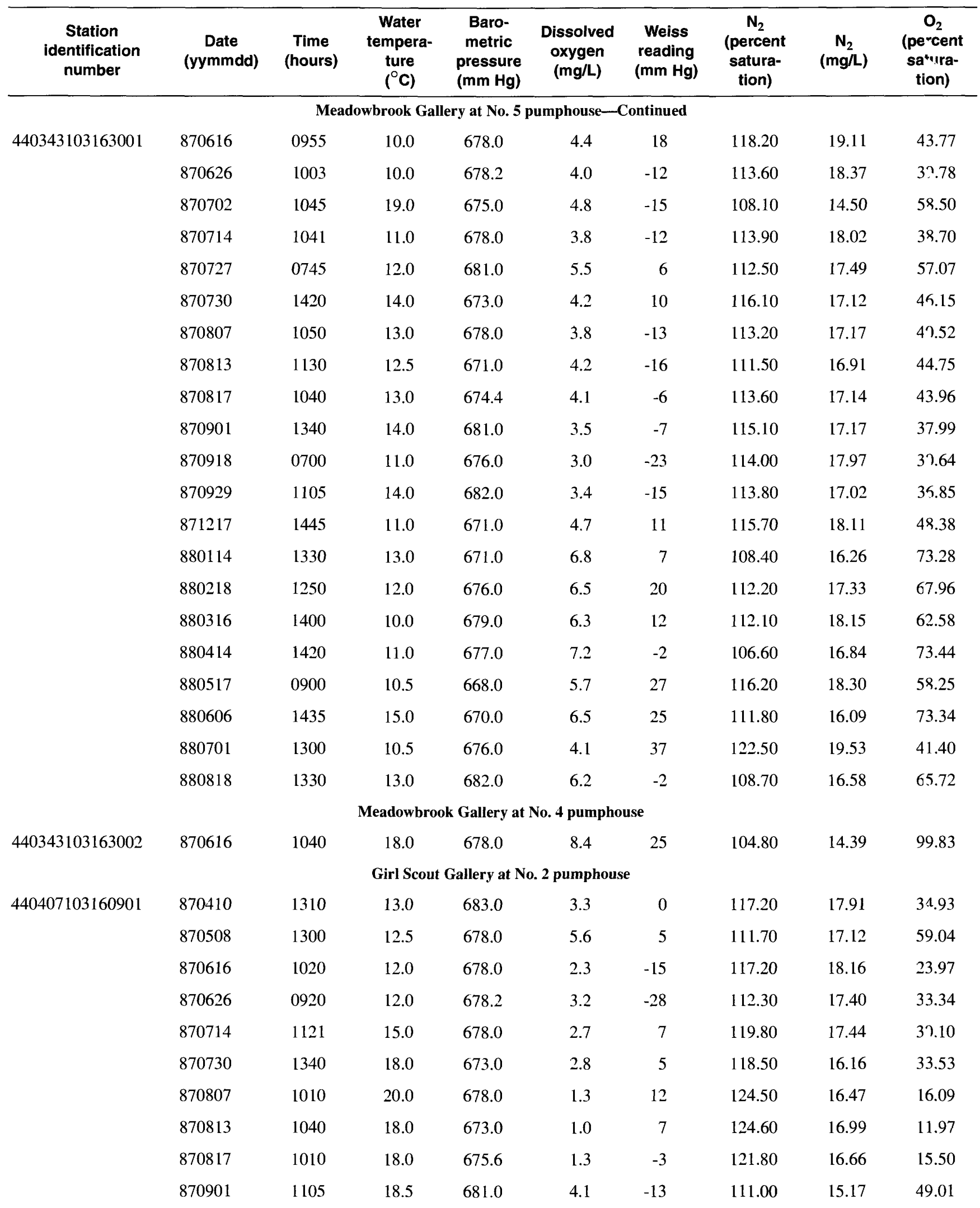


Table 18. Field measurements and calculated values of dissolved nitrogen and oxygen for selected sites in study area-Continued

[yymmdd, year, month, day; ${ }^{\circ} \mathrm{C}$. degrees Celsius; $\mathrm{mm} \mathrm{Hg}$, millimeters of mercury; $\mathrm{mg} / \mathrm{L}$, milligrams per liter]

\begin{tabular}{|c|c|c|c|c|c|c|c|c|c|}
\hline $\begin{array}{c}\text { Station } \\
\text { identification } \\
\text { number }\end{array}$ & $\begin{array}{c}\text { Date } \\
\text { (yymmdd) }\end{array}$ & $\begin{array}{c}\text { Time } \\
\text { (hours) }\end{array}$ & $\begin{array}{l}\text { Water } \\
\text { tempera- } \\
\text { ture } \\
\left({ }^{\circ} \mathrm{C}\right)\end{array}$ & $\begin{array}{c}\text { Baro- } \\
\text { metric } \\
\text { pressure } \\
(\mathrm{mm} \mathrm{Hg})\end{array}$ & $\begin{array}{l}\text { Dissolved } \\
\text { oxygen } \\
\text { (mg/L) }\end{array}$ & $\begin{array}{l}\text { Weiss } \\
\text { reading } \\
(\mathrm{mm} \mathrm{Hg})\end{array}$ & $\begin{array}{c}\mathrm{N}_{2} \\
\text { (percent } \\
\text { satura- } \\
\text { tion) }\end{array}$ & $\begin{array}{c}\mathrm{N}_{2} \\
(\mathrm{mg} / \mathrm{L})\end{array}$ & $\begin{array}{c}\mathrm{O}_{2} \\
\text { (percent } \\
\text { satura- } \\
\text { tion) }\end{array}$ \\
\hline \multicolumn{10}{|c|}{ Girl Scout Gallery at No. 2 pumphouse-Continued } \\
\hline \multirow[t]{4}{*}{440407103160901} & 870929 & 1145 & 15.0 & 683.0 & 3.2 & -18 & 113.70 & 16.68 & 35.40 \\
\hline & 880517 & 1015 & 12.0 & 668.0 & 5.5 & 25 & 115.80 & 17.67 & 58.20 \\
\hline & 880608 & 1340 & 14.5 & 673.0 & 4.7 & 10 & 114.50 & 16.72 & 52.21 \\
\hline & 880719 & 1345 & 15.0 & 683.0 & 6.2 & 42 & 116.20 & 17.05 & 68.60 \\
\hline \multicolumn{10}{|c|}{ Rapid Creek near Girl Scout Gallery } \\
\hline \multirow[t]{14}{*}{440407103160902} & 870616 & 1100 & 19.0 & 678.0 & 9.8 & 32 & 101.10 & 13.62 & 118.80 \\
\hline & 870714 & 1135 & 15.5 & 678.0 & 9.4 & 20 & 102.20 & 14.73 & 105.90 \\
\hline & 870730 & 1400 & 17.0 & 673.0 & 9.2 & 32 & 104.00 & 14.45 & 107.80 \\
\hline & 870807 & 1025 & 18.0 & 678.0 & 7.8 & 30 & 107.60 & 14.78 & 92.70 \\
\hline & 870813 & 1105 & 17.0 & 673.0 & 8.9 & 32 & 104.90 & 14.58 & 104.30 \\
\hline & 870817 & 1025 & 18.0 & 675.6 & 9.6 & 42 & 104.20 & 14.25 & 114.50 \\
\hline & 870901 & 1130 & 16.5 & 681.0 & 10.5 & 35 & 101.20 & 14.37 & 120.30 \\
\hline & 880606 & 1520 & 20.5 & 671.0 & 8.1 & 24 & 104.00 & 13.49 & 102.30 \\
\hline & 880701 & 1410 & 13.5 & 677.0 & 10.2 & 30 & 103.00 & 15.43 & 110.10 \\
\hline & 880715 & 1225 & 16.0 & 680.0 & 8.8 & 25 & 104.70 & 14.99 & 99.95 \\
\hline & 880728 & 1330 & 19.0 & 681.0 & 9.2 & 27 & 102.10 & 13.83 & 111.10 \\
\hline & 880802 & 1210 & 16.0 & 681.0 & 9.3 & 18 & 101.90 & 14.61 & 105.40 \\
\hline & 880819 & 1100 & 18.5 & 680.0 & 9.1 & 25 & 102.30 & 13.97 & 108.90 \\
\hline & 880921 & 0940 & 2.0 & 676.0 & 11.6 & 4 & 102.20 & 19.88 & 94.43 \\
\hline
\end{tabular}


Table 19. Isotope data for oxygen, hydrogen, and radium for selected sites in study area [yymmdd, year, month, day; dpm/L, disintegrations per minute per liter; --, no data]

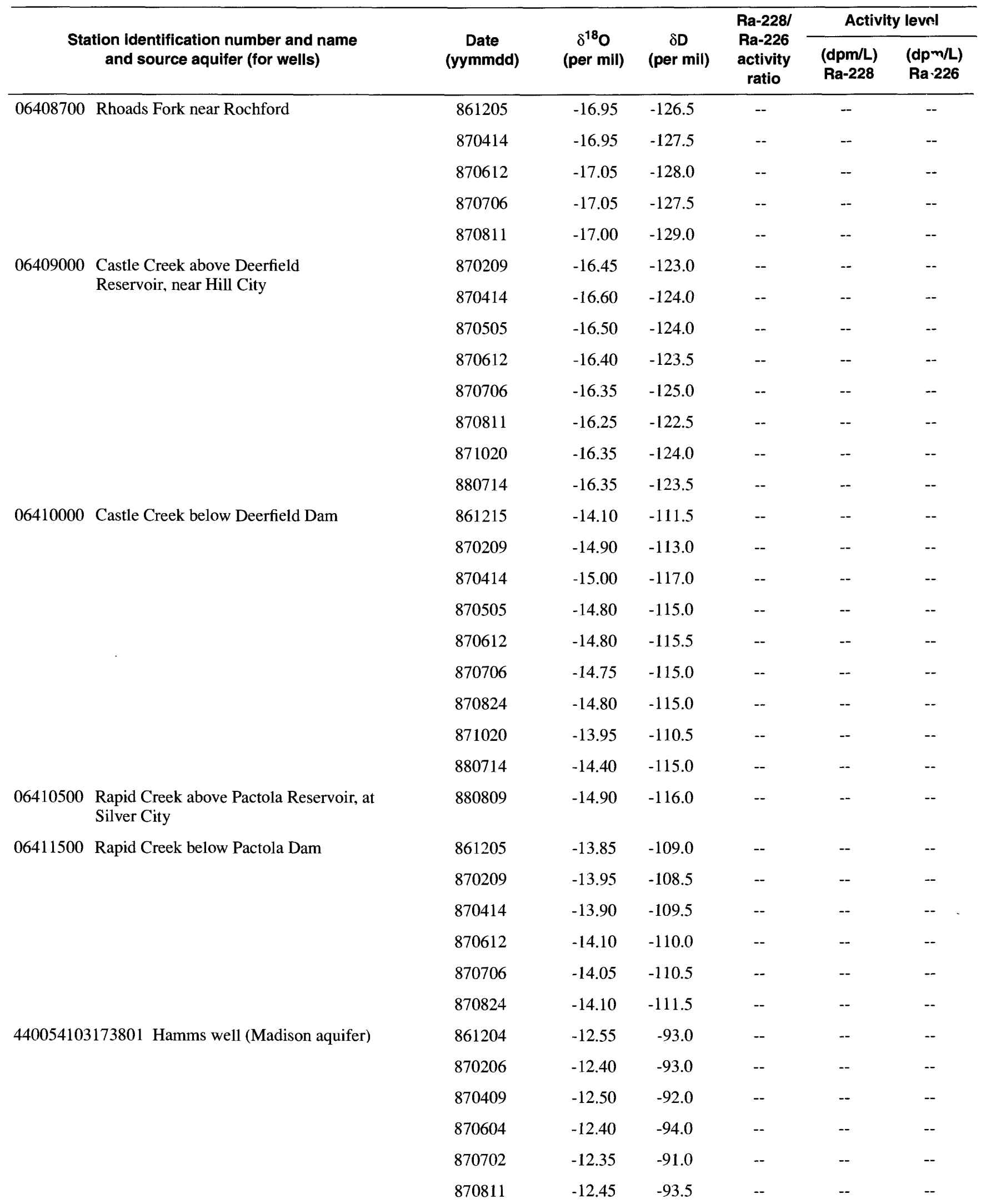


Table 19. Isotope data for oxygen, hydrogen, and radium for selected sites in study area-Continued [yymmdd, year, month, day; dpm/L, disintegrations per minute per liter; --, no data]

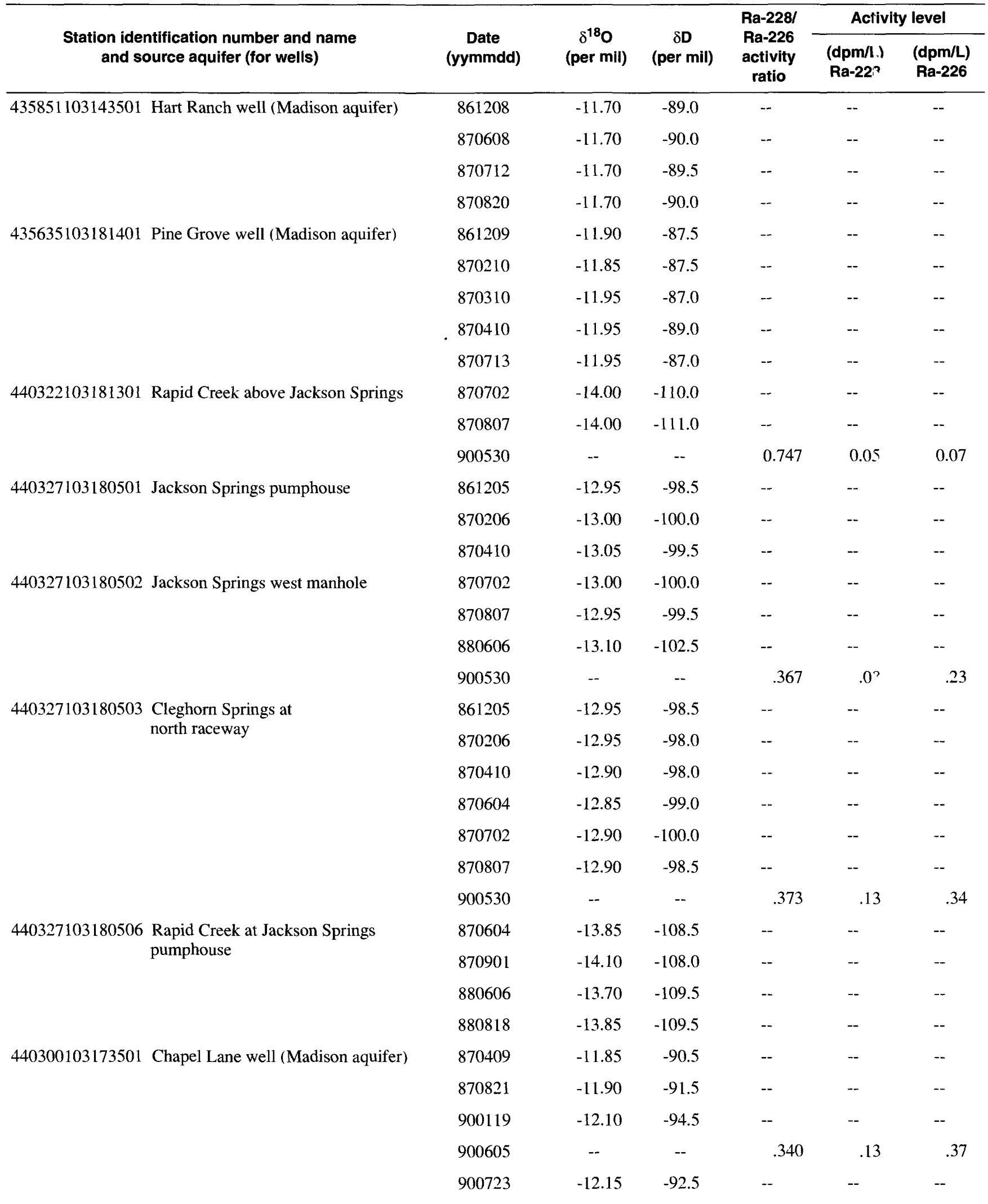


Table 19. Isotope data for oxygen, hydrogen, and radium for selected sites in study area-Continued

[yymmdd, year, month, day; dpm/L, disintegrations per minute per liter; --, no data]

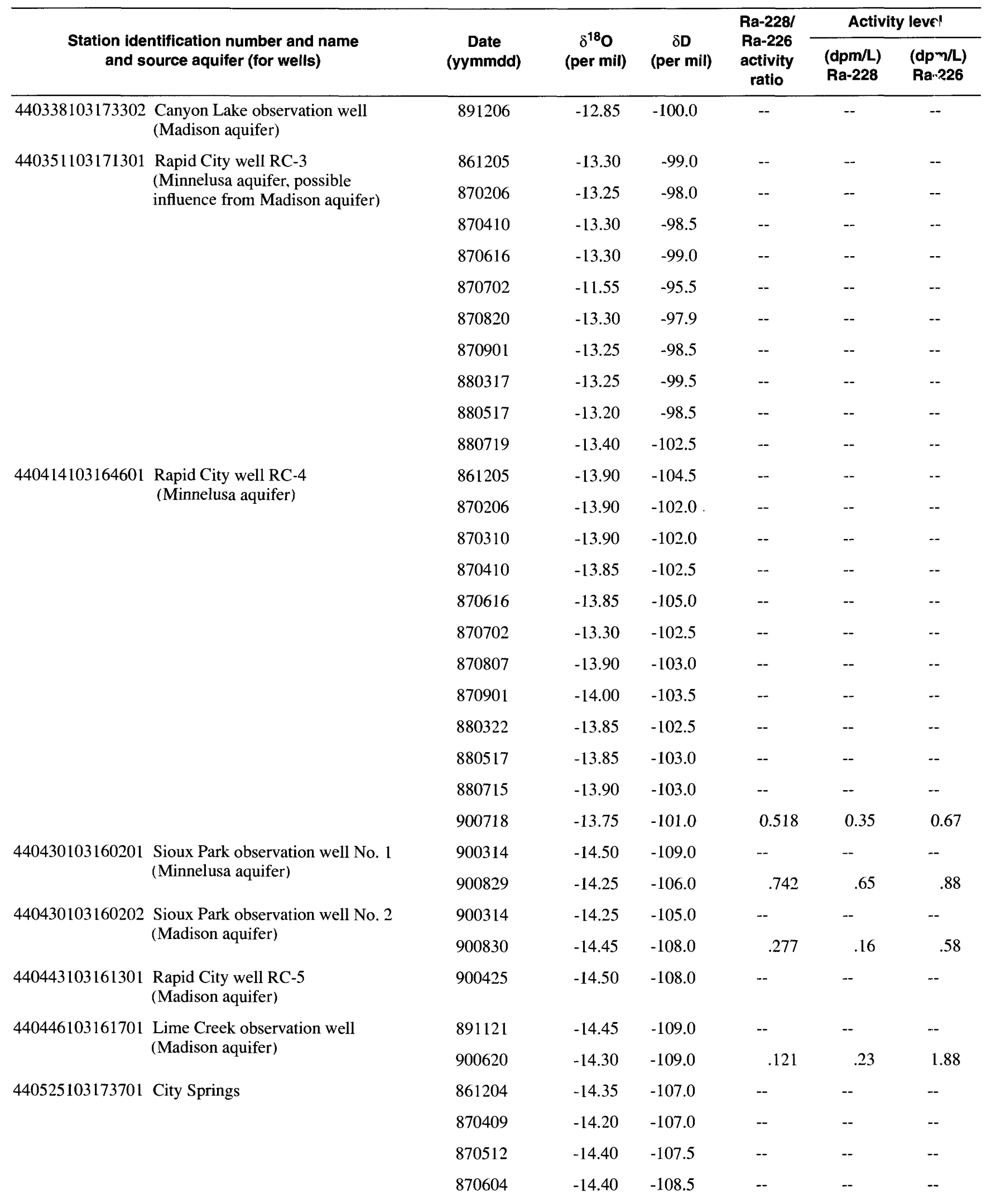


Table 19. Isotope data for oxygen, hydrogen, and radium for selected sites in study area-Continued [yymmdd, year, month. day: dpm/L, disintegrations per minute per liter; --, no data]

\begin{tabular}{|c|c|c|c|c|c|c|}
\hline \multirow[b]{2}{*}{$\begin{array}{l}\text { Station identification number and name } \\
\text { and source aquifer (for wells) }\end{array}$} & \multirow[b]{2}{*}{$\begin{array}{c}\text { Date } \\
\text { (yymmdd) }\end{array}$} & \multirow[b]{2}{*}{$\begin{array}{c}\delta^{18} \mathrm{O} \\
\text { (per mil) }\end{array}$} & \multirow[b]{2}{*}{$\begin{array}{c}\delta D \\
\text { (per mil) }\end{array}$} & \multirow{2}{*}{$\begin{array}{l}\text { Ra-228/ } \\
\text { Ra-226 } \\
\text { activity } \\
\text { ratio }\end{array}$} & \multicolumn{2}{|c|}{ Activity level } \\
\hline & & & & & $\begin{array}{l}(\mathrm{dpm} / \mathrm{L}) \\
\mathrm{Ra-22}\end{array}$ & $\begin{array}{l}\text { (dpm/L) } \\
\mathrm{Ra-226}\end{array}$ \\
\hline 440525103173701 City Springs (Cont.) & 870929 & -14.50 & -109.0 & -- & -- & -- \\
\hline $\begin{aligned} 440526103173001 & \text { Rapid City well RC-6 } \\
\text { (Madison aquifer, possible } & \text { influence from Minnelusa aquifer) }\end{aligned}$ & 900403 & -14.15 & -105.0 & -- & -- & -- \\
\hline $\begin{array}{c}440343103163003 \text { Rapid Creek at Meadowbrook } \\
\text { pumphouse }\end{array}$ & 880114 & -13.10 & -101.0 & -- & -- & -- \\
\hline \multirow{9}{*}{$\begin{array}{l}440343103163001 \text { Meadowbrook Gallery at No. } 5 \\
\text { pumphouse }\end{array}$} & 861205 & -13.25 & -102.0 & -- & -- & -- \\
\hline & 870114 & -13.10 & -100.5 & -- & -- & -- \\
\hline & 870206 & -12.90 & -100.5 & -- & -- & -- \\
\hline & 870310 & -13.15 & -103.5 & -- & -- & -- \\
\hline & 870410 & -12.95 & -102.5 & -- & -- & -- \\
\hline & 870616 & -13.70 & -106.5 & -- & -- & -- \\
\hline & 870807 & -13.30 & -102.0 & -- & -- & -- \\
\hline & 880818 & -13.30 & -105.0 & -- & -- & -- \\
\hline & 900531 & -- & -- & 1.014 & .12 & .12 \\
\hline 06413570 Rapid Creek above Jackson Blvd. & 900531 & -- & -- & .556 & .08 & .14 \\
\hline \multirow{10}{*}{$\begin{array}{l}440407103160901 \text { Girl Scout Gallery at No. } 2 \\
\text { pumphouse }\end{array}$} & 861205 & -13.20 & -103.0 & -- & -- & - \\
\hline & 870206 & -13.30 & -102.0 & - & -- & -- \\
\hline & 870310 & -13.35 & -104.0 & -- & -- & -- \\
\hline & 870410 & -13.35 & -103.0 & - & -- & -- \\
\hline & 870616 & -13.30 & -103.5 & -- & -- & -- \\
\hline & 870702 & -13.40 & -104.0 & -- & -- & -- \\
\hline & 870807 & -13.65 & -105.5 & -- & -- & -- \\
\hline & 870901 & -13.60 & -105.5 & -- & -- & -- \\
\hline & 880317 & -13.30 & -103.0 & -- & -- & -- \\
\hline & 880517 & -13.20 & -103.0 & -- & -- & -- \\
\hline
\end{tabular}


Table 19. Isotope data for oxygen, hydrogen, and radium for selected sites in study area-Continued [yymmdd, year, month, day; dpm/L, disintegrations per minute per liter; --, no data]

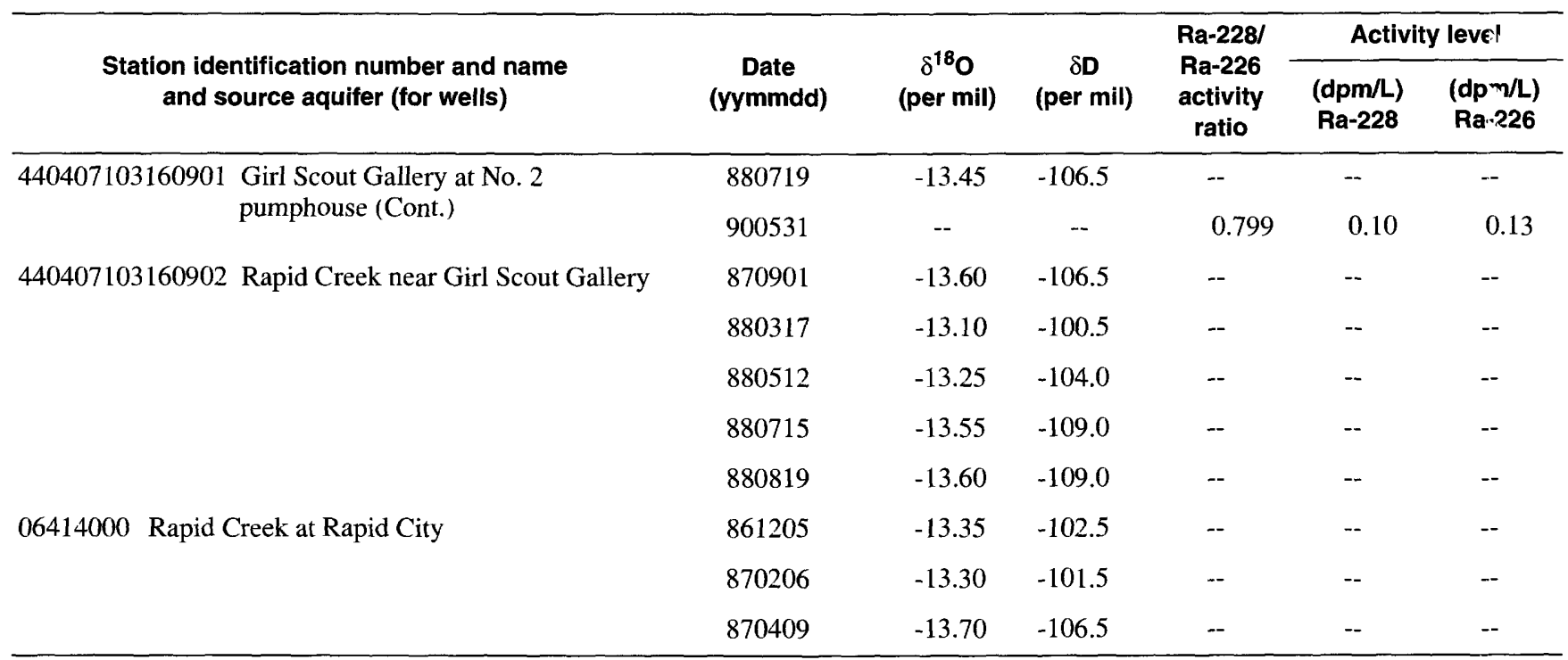

